\title{
The Reaction Chemistry of Aluminum(I, III) Compounds \\ Stabilized by Sterically Bulky Ligands
}

\author{
Dissertation \\ zur Erlangung des Doktorgrades \\ der Mathematisch-Naturwissenschaftlichen Fakultäten \\ der Georg-August-Universität zu Göttingen
}

vorgelegt von

Hongping Zhu

aus Jiangsu (CHINA)

Göttingen 2005 
D7

Referent:

Professor Dr. Dr. h.c. mult. H. W. Roesky

Korreferent:

Professor Dr. U. Klingebiel

Tag der mündlichen Prüfung:

2005-06-28 
Dedicated to my wife Qiaozhu Jiang and my son Yicheng Zhu for their love and affection 


\section{Acknowledge}

The work described in this doctoral thesis has been carried out under the guidance and supervision of Professor Dr. Dr. h.c. mult. Herbert W. Roesky at the Institute of Inorganic Chemistry of the Georg-August-University in Göttingen between January 2002 and December 2005.

My sincere thanks and gratitude are due to

\section{Professor Dr. Dr. h.c. mult. Herbert W. Roesky}

for his constant guidance, motivation, suggestions, and discussions throughout this work. His erudition and creative ideas deeply impressed me, and his pursuit and exploration of science will encourage me forever.

I would like to express my special thanks to Dr. Jianfang Chai for numerous discussions and happy cooperations during this work. I am thankful to Dr. Mathias Noltemeyer, Mr. Hans-Georg Schmidt, Dr. Qingjun Ma, Professor Jörg. Magull, Dr. Vojtech Jancik, and Mr. Denis Vidovic for their help in the X-ray crystal structural investigations and their friendship. I thank Mr. Wolfgang Zolke, Mr. Ralf Schöne, and Dr. Gernot Elter (NMR spectra), Dr. Dieter Böhler, Mr. Thomas Schuchardt, and Mr. Jörg Schöne (mass spectra), Mr. Mathias Hesse, and Mr. H.-J. Feine (IR spectra), Mr. Jürgen Schimkowiak, Mr. Martin Schlote, Mrs. H. Tappe and the staff of the Analytical Laboratories and Werkstatt for their timely support during this research work.

I would like to thank Dr. Hongjun Fan for the theoretical calculations and Mr. William A. Merrill and Professor Philp P. Power for offering a series of bulky azides. I thank Dr. Haijun Hao, Dr. Guangcai Bai, Dr. Yuqiang Ding, Dr. Ying Peng, Dr. Andreas Stasch for their help in the beginning of the work. I thank all colleagues in our research group for the good and motivating working atmosphere. I thank Dr. Cheng He, Mr. Torsten Blunck, Mr. Zhi Yang, Mr. Umesh Nehete, Dr. Holger Hohmeister, Dr. Peter Lobinger, Dr. S. Shravan Kumar, Mr. Leslie W. Pineda, Mr. Hans-Jürgen Ahn, Mr. Sharanappa Nembenna, Mr. Sanjay Singh, and Mr. Gurubasavaraja Prabhvodeyara Matada for their friendliness.

I am grateful to my former graduate advisers Professor Qiutian Liu and Professor Changneng Chen in Fujian Institute of Research on the Structure of Matter, Chinese Academy of Sciences, from whom I learnt my early lessons of research.

The sincere thanks are given to my family due to their full support and encouragement.

The financial support from the Göttinger Akademie der Wissenschaften and the Deutsche Forschungsgemeinschaft is gratefully acknowledged. 


\section{The Reaction Chemistry of Aluminum(I, III) Compounds \\ Stabilized by Sterically Bulky Ligands}

\section{Introduction}

2.1. A bulky chelating diamide aluminum monohydride: synthesis, structure, and reactions with $\mathrm{Me}_{3} \mathrm{SnF}$ and heavy group 16 elements

2.2. The stepwise hydrolysis of aluminum chloride iodide LAlClI in the presence of $N$-heterocyclic carbene as hydrogen halide acceptor new approach to alumoxane

2.4. Reactions of aluminum(I) monomer LAl with imidazol-2-ylidene and diphenyldiazomethane: a hydrogen transfer of the L ligand to the aluminum center and a formation of a diiminyl aluminum compound $\mathrm{LAl}\left(\mathrm{N}=\mathrm{CPh}_{2}\right)_{2}$

2.5. A rearrangement of azobenzene by interaction with an aluminum(I) monomer LAl

2.6. A stable aluminacyclopropene $\operatorname{LAl}\left(\eta^{2}-\mathrm{C}_{2} \mathrm{H}_{2}\right)$ and its end-on azide insertion to an aluminaazacyclobutene

2.7. A seven-membered aluminum allenyl sulfur heterocycle arising from the conversion of an aluminacyclopropene with $\mathrm{CS}_{2}$

2.8. Two types of intramolecular addition of an $\mathrm{Al}=\mathrm{N}$ multiple bonded monomer $\mathrm{LAl}=\mathrm{NAr}$ ' arised from the reaction of $\mathrm{LAl}$ with $\mathrm{N}_{3} \mathrm{Ar}$ '

\section{Experimental Sections}

4.1. General procedures

4.2. Physical measurements

4.5. Handling and disposal of solvents and residual wastes $\quad 84$

4.6. Crystal data and refinement details 86

5. References 


\section{Introduction}

Aluminum, bound almost exclusively to oxygen in various combinations, is the most abundant metal in the earth's crust. Once methods were developed to free useable quantities of the element from oxygen, applications for the element began developing rapidly. This growth has resulted in the ubiquity of the metal in today's world. ${ }^{[1]}$

The organoaluminum chemistry, due to the implications and potential, has been significant enough to excite widespread industrial interest. In 1859, ethylaluminum sesquiiodide (a 1:1 mixture of $\mathrm{EtAlI}_{2}$ and $\mathrm{Et}_{2} \mathrm{AlI}$ ) was first prepared from ethyl iodide and aluminum by Hallwachs and Schafarik. ${ }^{[2]}$ The subsequent synthesis of aluminum alkyls from mercury alkyls and aluminum metal was reported by Buckton and Odling in $1865 .^{[3]}$ The development of organoaluminum chemistry including the introductions of many new synthetic methods followed by researches on organomagnesium and organolithium reagents, the syntheses of a large number of new organoaluminum compounds, and the explorations of reactions of these compounds, however, started from the studies of Ziegler et al. in the early 1950's. These studies open a wide insight into the organoaluminum chemistry which lies dormant for ca. one hundred years, and make the potential of organoaluminum reagents for organic synthesis and polymerization come to light. The most notable important discovery is the polymerization of ethylene by Ziegler through a stepwise addition to triethylaluminum. ${ }^{[4,5]}$ This directly leads to the generation of Ziegler's catalysts based on transition-element compounds, which are normally formed by reaction of a transition-element halide or alkoxide or alkyl or aryl derivative with aluminum alkyl or alkyl halide. ${ }^{[6]}$ Correspondingly, the reactivity of the related organoaluminum compounds (Scheme 1) can be presented as follows: ${ }^{[7]}$

a) The highest reactivity is observed if all three valences of $\mathrm{Al}$ are bound to $\mathrm{C}$ or $\mathrm{C}$ and $\mathrm{H}$, respectively.

b) Many reactions are related to the electron deficiency of aluminum in its compounds of the type $\operatorname{AlR}_{3-n} X_{n}(n=2$ to 0$)$. 
c) Certain reversible relations exist between the $\mathrm{Al}-\mathrm{C}$ and the $\mathrm{Al}-\mathrm{H}$ bond.

d) Not only the $\mathrm{Al}-\mathrm{H}$ group but also $\mathrm{Al}-\mathrm{C}$ moiety can be added to $\mathrm{C}=\mathrm{C}$ and $\mathrm{C} \equiv \mathrm{C}$ bonds.

e) Organoaluminum compounds undergo a series of reactions more or less characteristic for many metal alkyls in which the aluminum is removed from carbon.

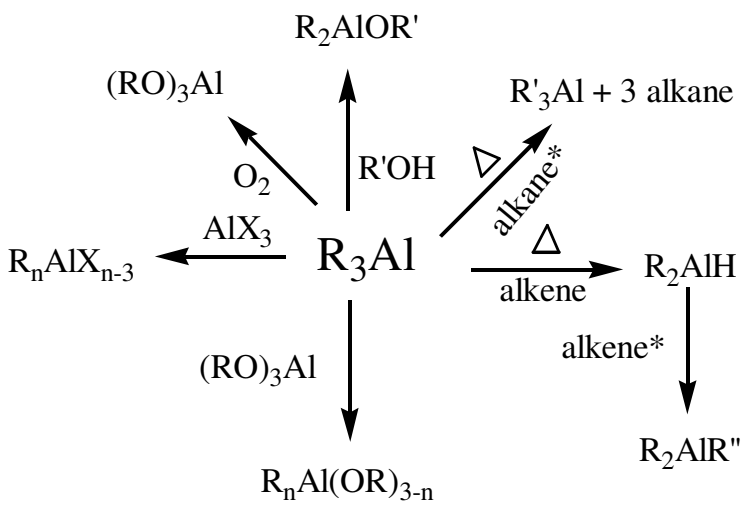

\section{Scheme 1}

In the following time, the organoaluminum chemistry was rapidly developed on the basis of Ziegler's classic studies, and some new properties of organoaluminum compounds are found. For example, alumoxanes prepared from the controlled hydrolysis of organoaluminum compounds or alternatively by their reactions with oxygen-containing compounds can be used as active catalysts in the polymerization of epoxides, aldehydes, and olefins. ${ }^{[8-14]}$ In 1980 , methylalumoxane (MAO) was found to be a highly active cocatalyst for group 4 metallocenes catalyzing ethylene and propylene polymerization by Kaminsky and Sinn. ${ }^{[15-16]}$ This has been of remarkable industrial importance.

In the meantime, the reactions of organoaluminum compounds towards unsaturated substrates, elements, or acidic hydrogen containing species are studied more systematically, comprehensively, and in detail, and many reaction types such as elimination, addition, insertion, reoxidation, $\mathrm{C}-\mathrm{H}$ activation, dimerization (or oligomerization), and substitution are presented. $^{[4]}$

In comparison to the trivalent organoaluminum chemistry, the low valent aluminum(I, II) chemistry which is characterized by the restricted use of the valence electrons of $\mathrm{Al}$ in 
compound formation is often invoked due to the roles of these $\mathrm{Al}(\mathrm{I}, \mathrm{II})$ species as possible intermediates in photochemical and radical reactions. Although the pursuit of compounds of low valent aluminum has a long history of over 50 years, most of the fascinating progress occurs only in recent years, especially in the case of $\mathrm{Al}(\mathrm{I})$ which may prove to be of much importance in the near future (Scheme 2). ${ }^{[17-18]}$

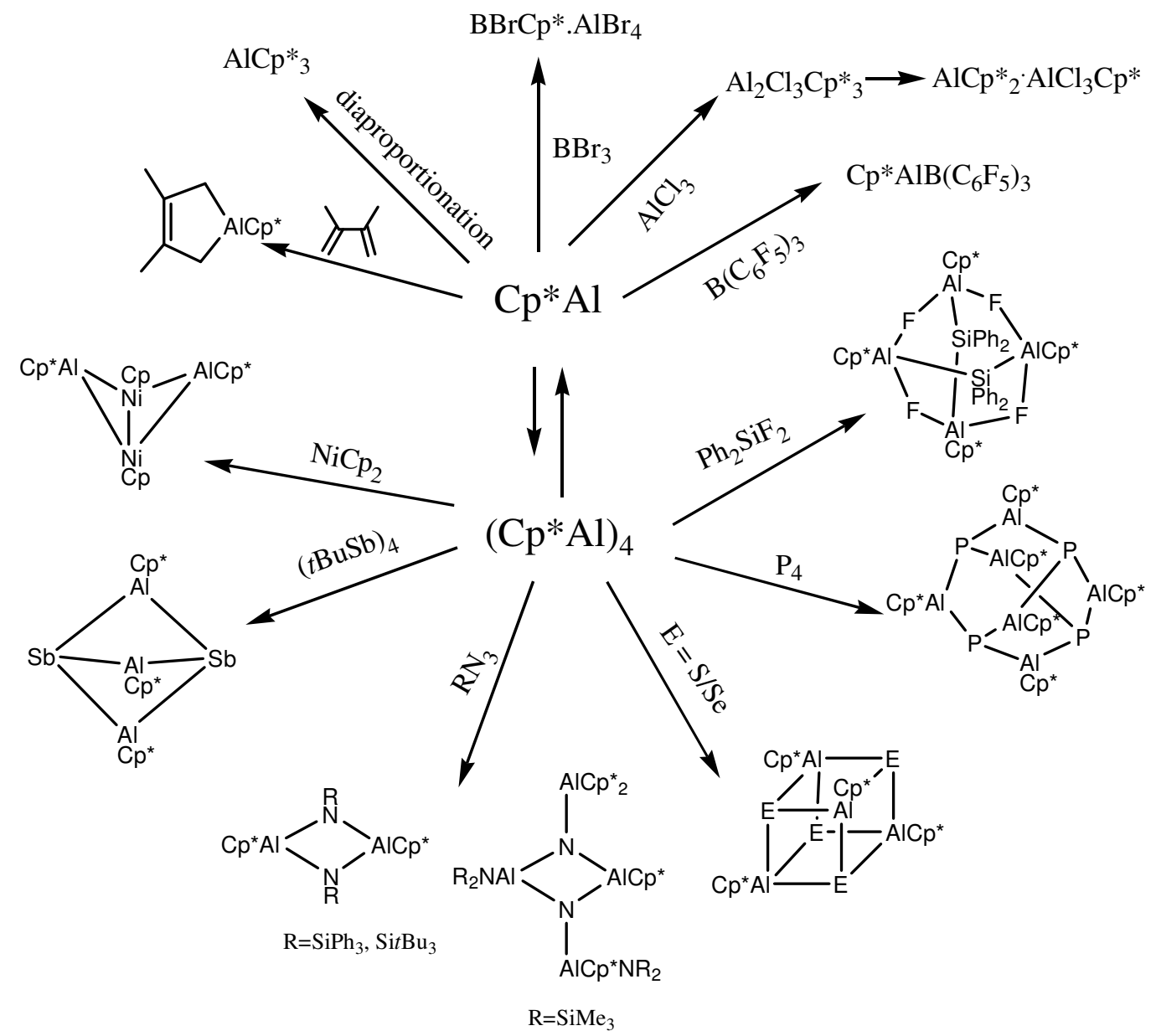

Scheme 2

In view of the syntheses of organoaluminum compounds, some of formula $\mathrm{AlR}_{\mathrm{n}} \mathrm{X}_{3-\mathrm{n}}(\mathrm{n}=$ 1-3) with simple $\mathrm{R}$ groups $(\mathrm{R}=\mathrm{H}, \mathrm{Me}, \mathrm{Et}, i \mathrm{Pr}, t \mathrm{Bu})$ have been commonly employed as hydroalumination or carboalumination reagents. These compounds have been commercially available. Due to the strong Lewis acidity of the $\mathrm{Al}$ center in these compounds, their reaction products are often found in high degree of association, even for reagents with fairly large organic groups such as $t \mathrm{Bu}, \mathrm{Ph}$. A large number of clusters of alane or carboalane with twoor three-dimensional net or cage structures have been synthezied, exhibiting the extensive 
organoaluminum chemistry. However, studies of this aspect often meet with challenges in detailed investigations of mechanism and stoichiometry.

The bulky organic ligand is usually employed to stabilize the metal center electronically and/or sterically. The introduction of a bulky organic ligand whether as a simple Lewis base donor, or in elimination reactions by gas $\left(\mathrm{H}_{2}, \mathrm{RH}\right)$ or $\mathrm{MX}_{\mathrm{n}}$ salts to the $\mathrm{Al}$ center, in fact, can efficiently reduce the condensation of products, and meanwhile, result in the formation of unusual compounds. This has also been successfully applied for the synthesis of low valent aluminum compounds. Moreover, by the stabilization of these large ligands, we can selectively perform changes of the functionalities at $\mathrm{Al}$, and intendedly control and design the reaction. All these help to understand organoaluminum chemistry and to investigate the possible reaction mechanisms.

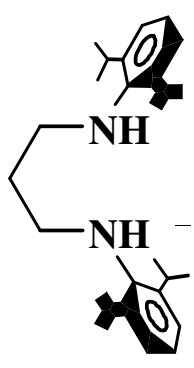

$\mathbf{L}^{\prime} \mathbf{H}_{2}$

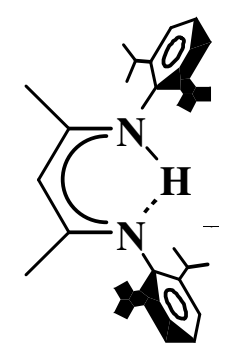

LH

\section{Scheme 3}

In this thesis, the two types of bulky ligands (Scheme 3) are employed for the synthesis of aluminum monohydride, monohalide, and monoalkyl (using $\mathrm{L}^{\prime} \mathrm{H}_{2}$ ), and aluminum(I) monomer, aluminum(III) dihydride and dihalide, and aluminacyclopropene (using LH), respectively. Subsequently, these compounds are further used as precursor to react with Lewis acidic species, fluorination agent, oxidation agents, carbene, water, unsaturated molecules, and so on. The sections 2.1.-2.8. will in detail point out the importance, recent research background, experimental results and discussion, and conclusion and remark of the chemistry 
of the bulky ligands stabilized aluminum compounds and their reactions. Based on these delineations, the objectives of the present work are:

(1) the chemical changes of aluminum functionalities in the stabilization of bulky ligands at Al.

(2) the exploration of the reaction chemistry of the aluminum(I) monomer LAl.

(3) the exploration of reaction chemistry of aluminacyclopropene $\operatorname{LAl}\left(\eta^{2}-\mathrm{C}_{2} \mathrm{RR}{ }^{\prime}\right)$. 


\section{Contents}

\subsection{A Bulky Chelating Diamide Aluminum Monohydride: Synthesis, Structure, and Reactions with $\mathrm{Me}_{3} \mathrm{SnF}$ and Heavy Group 16 Elements}

Abstract: A bulky chelating diamide aluminum monohydride $\left[\mathrm{ArN}\left(\mathrm{CH}_{2}\right)_{3} \mathrm{NAr}\right] \mathrm{AlH}\left(\mathrm{NMe}_{3}\right)(\mathrm{Ar}$ $\left.=2,6-i \operatorname{Pr}_{2} \mathrm{C}_{6} \mathrm{H}_{3}\right)$ (1) was prepared in excellent yield from the reaction of diamine ArNH $\left(\mathrm{CH}_{2}\right)_{3} \mathrm{HNAr}$ with a small excess of $\mathrm{AlH}_{3} \cdot \mathrm{NMe}_{3}$ in toluene. Subsequent fluorination of 1 with $\mathrm{Me}_{3} \mathrm{SnF}$ resulted in the formation of an aluminum monofluoride $\left[\mathrm{ArN}\left(\mathrm{CH}_{2}\right)_{3} \mathrm{NAr}\right] \mathrm{AlF}\left(\mathrm{NMe}_{3}\right)$ (2), indicating the reactivity of 1 despite the bulk of diamido $\mathrm{ArN}\left(\mathrm{CH}_{2}\right)_{3} \mathrm{NAr}$. Further reaction of 1 with elemental $E(E=S$, Se and Te $)$ proceeded in toluene at elevated temperature to yield aluminum chalcogenide $\left\{\left[\mathrm{ArNH}\left(\mathrm{CH}_{2}\right)_{3} \mathrm{NAr}\right] \mathrm{Al}(\mu-E)\right\}_{2}(E=S(3)$, Se (4), and Te (5)). Compounds 1 and 2 are well-separated monomers with a central aluminum atom in a tetrahedral environment. Compound 4 , however, is a dimer with a central $\mathrm{Al}_{2} \mathrm{Se}_{2}$ core bearing an ideal four-membered planar ring. The IR and ${ }^{1} \mathrm{H}$ NMR spectral data of compounds 3-5 suggest that a migration of the hydrogen from selenium to one of the nitrogen atoms at the diamide ligand is involved in the course of the reaction.

Studies of aluminum hydrides have received considerable attention due to their scientific importance and numerous applications. ${ }^{[4]}$ In recent years, much work has been devoted to aluminum hydrides in low aggregation, especially to the monomeric forms, since the synthetic process of monomeric aluminum hydride helps us to understand the reaction chemistry of surface-bound $\mathrm{AlH}_{n}$ groups developed during thin film growth from organoaluminum sources. ${ }^{[19-20]}$ Moreover, aluminum hydrides of low aggregation can be used as very effective precursors for preparing aluminum chalcogenides. ${ }^{[21]}$ However, reactions involving aluminum hydrides of low aggregation with chalcogen or organochalcogenides have been reported to a lesser extent. Raston et al. ${ }^{[22-25]}$ investigated the reaction of trimethylamine adduct of alane 
$\mathrm{Me}_{3} \mathrm{~N} \cdot \mathrm{AlH}_{3}$ with chalcogen or organochalcogenide. Power et al. ${ }^{[26]}$ reported one example of the reaction of aluminum dihydride with organochalcogenide and our group discussed the reaction of a series of aluminum dihydrides with chalcogen, ${ }^{[21,27-30]}$ where the isolation and structural characterization of some novel compounds (such as $\mathrm{LAl}(\mathrm{SeH})_{2}$, $\operatorname{LAl}(\mathrm{SeH}) \mathrm{Se}(\mathrm{SeH}) \mathrm{AlL},{ }^{[21]} \mathrm{LAl}(\mathrm{SH})_{2}{ }^{[27]}(\mathrm{L}=\mathrm{N}(\mathrm{Ar}) \mathrm{C}(\mathrm{Me}) \mathrm{CHC}(\mathrm{Me}) \mathrm{N}(\mathrm{Ar}), \quad \mathrm{Ar}=2,6-$ $\left.i \mathrm{Pr}_{2} \mathrm{C}_{6} \mathrm{H}_{3}\right) ; \quad(\mathrm{RAlE})_{2}\left(\mathrm{R}=2,4,6-t \mathrm{Bu}_{3} \mathrm{C}_{6} \mathrm{H}_{2}, \mathrm{E}=\mathrm{S} ;{ }^{[26]} \mathrm{R}=\mathrm{N}\left(\mathrm{SiMe}_{3}\right) \mathrm{C}(\mathrm{Ph}) \mathrm{C}\left(\mathrm{SiMe}_{3}\right)_{2},{ }^{[28]} 2,6-\right.$ $\left.\left(\mathrm{Et}_{2} \mathrm{NCH}_{2}\right)_{2} \mathrm{C}_{6} \mathrm{H}_{3}, 2-\mathrm{Et}_{2} \mathrm{NCH}_{2}-6-\mathrm{MeC}_{6} \mathrm{H}_{3},{ }^{[29]} \mathrm{E}=\mathrm{Se}, \mathrm{Te}\right)$, trans $-\left[\left\{\mathrm{Me}_{3} \mathrm{~N}(\mathrm{H}) \mathrm{Al}(\mu-\mathrm{E})\right\}_{2}\right](\mathrm{E}=\mathrm{Se}$, $\mathrm{Te}),{ }^{[23]} \operatorname{trans}\left[\left\{\mathrm{Me}_{3} \mathrm{~N}(\mathrm{PhTe}) \mathrm{Al}(\mu-\mathrm{Se})\right\}_{2}\right] ;^{[24]}\left[\left(\eta^{1}-3,5-t \mathrm{Bu}_{2} \mathrm{pz}(\mu-\mathrm{Al}) \mathrm{H}\right]_{2} \mathrm{E}(\mathrm{E}=\mathrm{S}, \mathrm{Se}, \mathrm{Te}){ }^{[30]}\right.$ $\mathrm{Me}_{3} \mathrm{NAl}(\mathrm{ER})_{3}\left(\mathrm{E}=\mathrm{Se}, \mathrm{R}=\mathrm{Et}, \mathrm{Ph}, \mathrm{CH}_{2} \mathrm{Ph} ; \mathrm{E}=\mathrm{Te}, \mathrm{R}=\mathrm{Ph}\right)^{[22]}$ and $\left.\mathrm{Al}_{4} \mathrm{Se}_{5}(\mathrm{H})_{2}\left(\mathrm{NMe}_{3}\right)_{4}{ }^{[24]}\right)$ showed a rich chemistry. Nonetheless, the reaction of monomeric bulky aluminum monohydrides with chalcogen, which might generate the corresponding monomeric Al-EH moieties, have not been reported so far. Therefore we became interested in finding the sufficiently bulky ligand to synthesize the intramolecularly stabilized aluminum monohydride, and further studies on its reactivity.

The divalent bulky chelating diamide ligand $\left[\mathrm{ArN}\left(\mathrm{CH}_{2}\right)_{3} \mathrm{NAr}\right]^{2-}\left(\mathrm{Ar}=2,6-i \mathrm{Pr}_{2} \mathrm{C}_{6} \mathrm{H}_{3}\right)$ is currently exhibiting growing interests ${ }^{[31]}$ due to its special steric and electronic properties to control effectively the geometry at the metal center. The known complexes having this ligand include main group metal ( $\mathrm{Li}, \mathrm{K}, \mathrm{Al})$ and transition metal $(\mathrm{Ti}, \mathrm{Zr}, \mathrm{Y}, \mathrm{Lu})$ derivatives. $^{[31-35]}$ The only reported aluminum complexes are a series of compounds containing alkyl and aryl groups $\left[\mathrm{ArN}\left(\mathrm{CH}_{2}\right)_{3} \mathrm{NAr}\right] \mathrm{AlR}\left(\mathrm{R}=\mathrm{Me}, i \mathrm{Bu}, \mathrm{C}_{6} \mathrm{~F}_{5}\right) .{ }^{[35]}$ Herein we report on the synthesis and characterization of a bulky chelating diamide aluminum monohydride $\left[\mathrm{ArN}\left(\mathrm{CH}_{2}\right)_{3} \mathrm{NAr}\right] \mathrm{AlH}\left(\mathrm{NMe}_{3}\right)\left(\mathrm{Ar}=2,6-i \mathrm{Pr}_{2} \mathrm{C}_{6} \mathrm{H}_{3}\right)(\mathbf{1})$. The metathesis of $\mathbf{1}$ with $\mathrm{Me}_{3} \mathrm{SnF}$ to give a monofluoride $\left[\mathrm{ArN}\left(\mathrm{CH}_{2}\right)_{3} \mathrm{NAr}\right] \mathrm{AlF}\left(\mathrm{NMe}_{3}\right)$ (2) and its reaction with heavy group 16 elements to afford dimeric aluminum chalcogenide $\left\{\left[\operatorname{ArNH}\left(\mathrm{CH}_{2}\right)_{3} \mathrm{NAr}\right] \mathrm{Al}(\mu-\mathrm{E})\right\}_{2}(\mathrm{E}=\mathrm{S}(3)$, Se (4), and Te (5)) are also described.

Although the syntheses of aluminum hydrides have been reported in a number of publica 
-tions, ${ }^{[36]}$ the use of $\mathrm{AlH}_{3} \cdot \mathrm{NMe}_{3}$ as a precursor to react with $N$-substituted diamine, diimine and analogues containing $\mathrm{NH}$ groups or $\mathrm{E}\left(\mathrm{SiMe}_{3}\right)_{2}(\mathrm{E}=\mathrm{P}, \mathrm{As})$ under elimination of $\mathrm{H}_{2}$ or $\mathrm{HSiMe}_{3}$ has shown a facile route to aluminum hydrides of low aggregation. ${ }^{[21,37-44]}$ Reaction of the diamine $\left[\mathrm{ArNH}\left(\mathrm{CH}_{2}\right)_{3} \mathrm{HNAr}\right]$ with a small excess of $\mathrm{AlH}_{3} \cdot \mathrm{NMe}_{3}$ in toluene under heating $\left(80{ }^{\circ} \mathrm{C}\right)$ affords the intramolecularly stabilized diamide aluminum monohydride $\left[\mathrm{ArN}\left(\mathrm{CH}_{2}\right)_{3} \mathrm{NAr}\right] \mathrm{AlH}\left(\mathrm{NMe}_{3}\right)(\mathbf{1})$ in excellent yield. Subsequent fluorination of $\mathbf{1}$ with $\mathrm{Me}_{3} \mathrm{SnF}$ either at room temperature or at elevated temperature $\left(80^{\circ} \mathrm{C}\right)$ results in the formation of an aluminum monofluoride $\left[\mathrm{ArN}\left(\mathrm{CH}_{2}\right)_{3} \mathrm{NAr}\right] \mathrm{AlF}\left(\mathrm{NMe}_{3}\right)(\mathbf{2}$, Scheme 4).

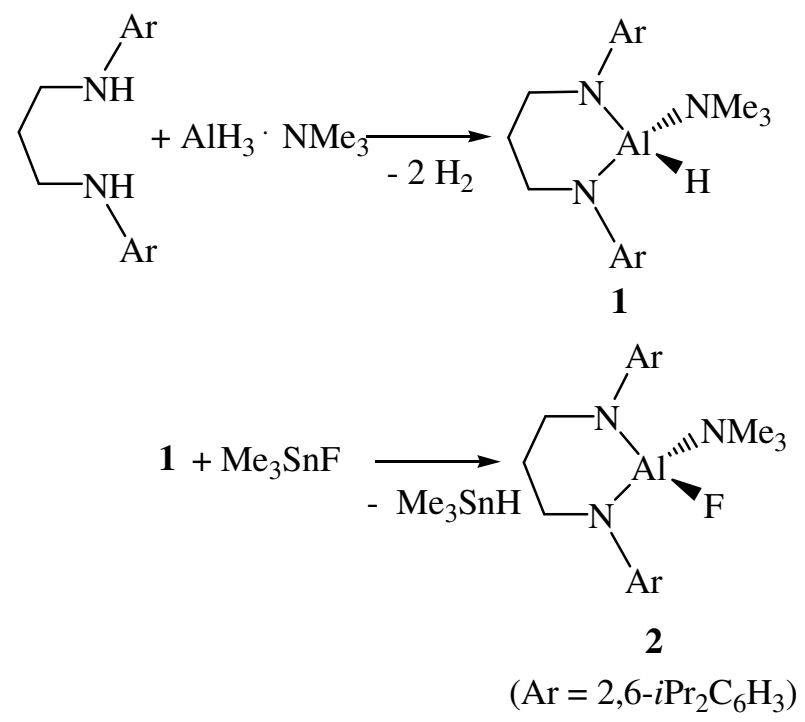

\section{Scheme 4}

Complexes 1 and $\mathbf{2}$ are characterized by NMR, MS (EI), IR spectroscopy and elemental analyses. The presence of hydride in $\mathbf{1}$ is evident from the IR spectrum. The broad IR band at $1799 \mathrm{~cm}^{-1}$ can be assigned to the Al-H stretching absorption. ${ }^{[45]}$ In the IR spectrum of 2 , this absorption disappears, indicating a complete fluorination of $\mathbf{1}$. The ${ }^{19} \mathrm{~F}$ NMR spectrum of $\mathbf{2}$ exhibits one singlet resonance (-175.4 ppm), which can be comparable to those terminal $\mathrm{Al}-\mathrm{F}$ resonances in a series of compounds $\left(\mathrm{ArN}\left[\mathrm{Si}(\mathrm{R}) \mathrm{Me}_{2}\right] \mathrm{AlF}_{2} \cdot \mathrm{THF}: \mathrm{Ar}=2,6-i \mathrm{Pr}_{2} \mathrm{C}_{6} \mathrm{H}_{3}, \mathrm{R}=\mathrm{Me}\right.$, $-178.1 ; \mathrm{R}=i \operatorname{Pr},-177.0 ; \mathrm{R}=t \mathrm{Bu},-175.1 ; \mathrm{Ar}=2,6-\mathrm{Me}_{2} \mathrm{C}_{6} \mathrm{H}_{3}, \mathrm{R}=t \mathrm{Bu},-175.0 ; \mathrm{R}=2,4,6-$ $\left.\mathrm{Me}_{3} \mathrm{C}_{6} \mathrm{H}_{2},-175.9 \mathrm{ppm}\right) .{ }^{[46]}$ In the ${ }^{1} \mathrm{H}$ NMR spectra of $\mathbf{1}$ and $\mathbf{2}$ the presence of the complex resonances for the backbone protons of the diamide ligand (two isopropyl methine $(\mathrm{CHMe})$, 


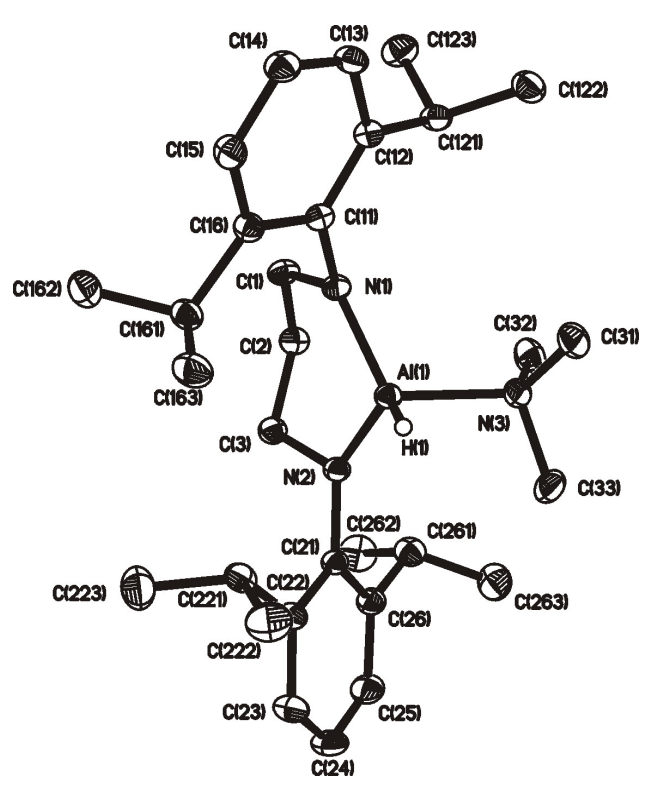

Figure 1. Molecular structure of $\mathbf{1}$. $\mathrm{H}$ atoms are omitted for clarity except for the Al-H group. Selected bond lengths $(\AA)$ and angles $\left(^{\circ}\right)$ : $\mathrm{Al}(1)-\mathrm{N}(1)$ 1.820(1), $\mathrm{Al}(1)-\mathrm{N}(2) 1.828(1), \mathrm{Al}(1)-$ $\mathrm{N}(3)$ 2.024(2), $\mathrm{Al}(1)-\mathrm{H}(1)$ 1.52, N(1)-Al(1)-N(2) 106.52(6), H(1)-Al(1)-N(3) 96.0. four isopropyl methyl $(\mathrm{CHMe})$, two methene $\left(\mathrm{NCH}_{2}\right)$ and two methene $\left(\mathrm{NCH}_{2} \mathrm{CH}_{2}\right)$ resonances) are consistent with a pseudotetrahedral geometry and Cs symmetry about Al. Similar resonances are observed in compounds $\left[\mathrm{M}\left\{\mathrm{ArN}\left(\mathrm{CH}_{2}\right)_{3} \mathrm{NAr}\right\}\left(\eta-\mathrm{C}_{5} \mathrm{H}_{5}\right) \mathrm{Cl}\right](\mathrm{M}=\mathrm{Zr}, \mathrm{Y}$; Ar $\left.=2,6-i \operatorname{Pr}_{2} \mathrm{C}_{6} \mathrm{H}_{3}\right) .{ }^{[31,33]}$ The resonance for the $\mathrm{Al}-\mathrm{H}$ proton in $\mathbf{1}$ is not seen, which is, however, typical for amidoaluminum hydride species. ${ }^{[38]}$ Substitution of $\mathrm{Al}-\mathrm{H}$ in $\mathbf{1}$ by $\mathrm{Al}-\mathrm{F}$ has a stronger effect on the chemical shift of the $\mathrm{NMe}_{3}$ group $(1.66, \mathbf{1} ; 1.75 \mathrm{ppm}, 2)$, while a smaller effect is observed for the backbone protons of the ligand. The MS (EI) spectrum shows the molecular ion of $\left[M^{+}-\mathrm{NMe}_{3}\right]$ for $\mathbf{1}$, and $\left[M^{+}\right]$and $\left[M^{+}-\mathrm{NMe}_{3}\right]$ for $\mathbf{2}$ and the single crystal X-ray structural determinations of $\mathbf{1}$ and $\mathbf{2}$ confirm the composition of $\left[\operatorname{ArN}\left(\mathrm{CH}_{2}\right)_{3} \mathrm{NAr}\right] \mathrm{AlR}\left(\mathrm{NMe}_{3}\right)(\mathrm{R}=\mathrm{H}, \mathbf{1} ; \mathrm{F}, \mathbf{2})$, where the former contains half a molecule of $n$ hexane per molecule of complex $\mathbf{1}$ in the asymmetric unit.

Compounds $\mathbf{1}$ and $\mathbf{2}$ are well-separated monomers with a central aluminum atom both in a distorted tetrahedral environment (Figures 1 and 2 with selected bond lengths and angles). The terminal Al-H bond length $(1.52 \AA)$ is closer to those in compounds $(2,4,6$ $\left.t \mathrm{Bu}_{3} \mathrm{C}_{6} \mathrm{H}_{2}\right)_{2} \mathrm{AlH}^{[47]}(1.53(4) \AA)$ and $\left[\mathrm{HAl}\left(\mathrm{NMe}_{2}\right)_{3}\right]^{-[48]}(1.52(2) \AA)$, but shorter than those in 
$\mathrm{AlH}(\mathrm{Cl})\left[t \mathrm{BuNCH}_{2} \mathrm{CH}_{2} \mathrm{~N}(t \mathrm{Bu}) \mathrm{H}\right]^{[37]}\left(\begin{array}{ll}1.60 & \AA\end{array}\right), \quad \mathrm{Al}_{2}\left(\mu-\mathrm{NEt}_{2}\right)_{2}\left[\mathrm{~N}(i \mathrm{Pr})_{2}\right]_{2} \mathrm{H}_{2}{ }^{[49]} \quad\left(\begin{array}{ll}1.67 & \AA\end{array}\right)$ and $\left(2,4,6-t \mathrm{Bu}_{3} \mathrm{C}_{6} \mathrm{H}_{2}\right) \mathrm{Al}(\mathrm{H}) \mathrm{Cl} \cdot \mathrm{THF}^{[50]}(1.73(5) \AA)$. The terminal Al-F separation $(1.678(1) \AA)$ is in the range of 1.657-1.681 $\AA$ observed in compound $\left[\left(\mathrm{Me}_{3} \mathrm{Si}_{3}\right)_{3} \mathrm{CAlF}_{2}\right]_{3}{ }^{[51]}$ and somewhat longer

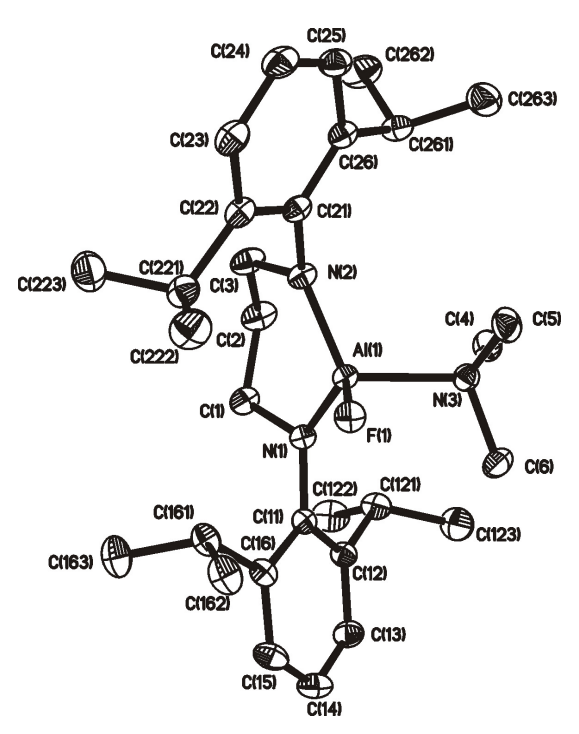

Figure 2. Molecular structure of 2. H atoms are omitted for clarity. Selected bond lengths $(\AA)$ and angles $\left({ }^{\circ}\right)$ : $\mathrm{Al}(1)-\mathrm{N}(1)$ 1.810(2), $\mathrm{Al}(1)-\mathrm{N}(2)$ 1.804(2), $\mathrm{Al}(1)-\mathrm{N}(3) 2.000(2), \mathrm{Al}(1)-\mathrm{F}(1)$

$$
\text { 1.678(1), N(1)-Al(1)-N(2) 107.45(7), F(1)-Al(1)-N(3) 93.00(6). }
$$

than those in $\left[\left\{\left(2,6-i \mathrm{Pr}_{2} \mathrm{C}_{6} \mathrm{H}_{3}\right) \mathrm{N}\left(\mathrm{SiMe}_{3}\right) \mathrm{AlF}_{2}\right\}_{3}\right]^{[46]}(1.634-1.642 \AA)$ and $\mathrm{AlF}_{3}{ }^{[52]}(1.63 \AA)$, as determined by electron diffraction. The diamide ligand chelates the $\mathrm{Al}$ atom to form an $\mathrm{AlN}_{2} \mathrm{C}_{3}$ six-membered non-planar ring, in which $\mathrm{Al}(1)$ and $\mathrm{C}(2)$ occupy the head positions with distances to the quasi-plane $\mathrm{N}(1)-\mathrm{N}(2)-\mathrm{C}(3)-\mathrm{C}(1)$ (the mean deviation $\Delta=0.0716 \AA$ ) of 0.1034 and $0.6852 \AA$ in 1 and the plane $\mathrm{N}(1)-\mathrm{N}(2)-\mathrm{C}(3)-\mathrm{C}(1)(\Delta=0.0316 \AA)$ of -0.0109 and $0.6730 \AA$ in 2 , respectively. It is obvious that the former displays a boat conformation and the latter a flattened chair conformation, as can be explained in terms of strain imposed by the $\mathrm{Ar}$ group. The $\mathrm{F}$ atom owns a stronger electron attractive tendency than the $\mathrm{H}$ atom. This generates different charge distribution for the central $\mathrm{Al}$ atom of $\mathbf{1}$ and $\mathbf{2}$, and gives rise to a small difference of the $\mathrm{Al}-\mathrm{N}_{\text {diamide }}$ bond distance between $\mathbf{1}$ and 2 (average $1.824, \mathbf{1} ; 1.807 \AA$, 2), as well as the $\mathrm{Al}-\mathrm{N}_{\mathrm{NMe}}$ bond distance $(2.024(2), 1 ; 2.000(2) \AA$, 2) and the $\mathrm{N}(1)-\mathrm{Al}(1)-$ $\mathrm{N}(2)$ chelating angle $\left(106.52(6), \mathbf{1} ; 107.45(7)^{\circ}, \mathbf{2}\right)$. The $\mathrm{Al}-\mathrm{N}_{\text {diamide }}$ distances in $\mathbf{1}$ and $\mathbf{2}$ can be 
compared with the terminal Al-N (amide) distances in $\mathrm{CH}_{2}\left(\mathrm{CH}_{2} \mathrm{CMe}_{2}\right)_{2} \mathrm{NAlH}_{2} \cdot \mathrm{NMe}_{3}{ }^{[44]}$ $(1.838(2) \quad \AA), \quad \mathrm{AlH}(\mathrm{Cl})\left[t \mathrm{BuNCH}_{2} \mathrm{CH}_{2} \mathrm{~N}(t \mathrm{Bu}) \mathrm{H}\right]^{[37]} \quad(1.80(1) \quad \AA) \quad$ and $\quad\{\mathrm{Al}(\mu-$ $\left.\mathrm{H})\left[\mathrm{N}\left(\mathrm{CMe}_{2} \mathrm{CH}_{2}\right)_{2} \mathrm{CH}_{2}\right]_{2}\right\}_{2}{ }^{[53]}(1.836(3) \AA)$, and are longer than the Al- $\mathrm{N}_{\text {diamide }}$ bond lengths in the three coordinate aluminum compound $\left[\mathrm{ArN}\left(\mathrm{CH}_{2}\right)_{3} \mathrm{NAr}\right] \mathrm{AlMe}{ }^{[35]}(1.760(3), 1.766(3) \AA)$. The $\mathrm{Al}-\mathrm{N}_{\mathrm{NMe} 3}$ distances in $\mathbf{1}$ and $\mathbf{2}$ are as expected in a comparable range. ${ }^{[44,54-55]}$

The successful fluorination of 1 using $\mathrm{Me}_{3} \mathrm{SnF}$ is indicative of its reactivity despite the steric hindrance of the bulky ligand. Treatment of $\mathbf{1}$ with equivalent amounts of sulfur, selenium and tellurium proceeded in toluene at elevated temperature to afford solvated aluminum sulfide (3) as light yellow crystals, selenide (4) as yellow crystals and telluride (5) as green-yellow crystals, respectively. The former two compounds are obtained in good yield and the latter in moderate yield (Equation 1).

$$
\begin{aligned}
2\left[\operatorname{ArN}\left(\mathrm{CH}_{2}\right)_{3} \mathrm{NAr}\right] \mathrm{AlH}\left(\mathrm{NMe}_{3}\right)+2 \mathrm{E} \rightarrow\left\{\left[\operatorname{ArNH}\left(\mathrm{CH}_{2}\right)_{3} \mathrm{NAr}\right] \mathrm{Al}(\mu-\mathrm{E})\right\}_{2}+2 \mathrm{NMe}_{3} \\
\mathrm{E}=\mathrm{S}(\mathbf{3}), 80^{\circ} \mathrm{C}, 12 \mathrm{~h} \\
\quad=\mathrm{Se}(\mathbf{4}), \text { reflux, } 12 \mathrm{~h} \\
=\mathrm{Te}(\mathbf{5}), \text { reflux, } 120 \mathrm{~h}
\end{aligned}
$$

Compounds 3-5 are air and moisture sensitive and soluble in hot toluene and benzene, while poorly soluble in THF, $\mathrm{CHCl}_{3}$ and $n$-hexane. They were characterized by IR and NMR spectroscopy and MS (EI) spectrometry, as well as elemental analyses. The MS (EI) spectra of 3-5 show the dimeric molecular ion with the correct isotope pattern and their ${ }^{1} \mathrm{H}$ NMR spectroscopies show the very similar characters of the ligand including the resonances of solvent toluene protons. The doublets in the range of $\delta 1.10-1.25$, one septet centered at ca. $\delta$ 3.38 and a multiplet at $\delta 7.02-7.10$ are corresponding to the protons of the $2,6-i \mathrm{Pr}_{2} \mathrm{C}_{6} \mathrm{H}_{3}$ group. One broad singlet at ca. $\delta 1.36$ can be assigned to $\mathrm{NH}$ resonance ${ }^{[37,39]}$ with satisfied integral intensity indicating two protons. Two areas of unresolved multiplet resonances centered at ca. $\delta 1.78$ and 3.00 arise from the six non-equivalent methylene protons, where the latter might be formed from overlapping proton resonances of the two amido $\mathrm{NCH}_{2}$ and two 
amine $\mathrm{HNCH}_{2}$ groups. The IR spectra exhibit the $\mathrm{NH}$ absorption in the $\tilde{v}_{\mathrm{NH}}$ region $^{[37-38]}$ $\left(3190, \mathbf{3} ; 3187, \mathbf{4} ; 3185 \mathrm{~cm}^{-1}, \mathbf{5}\right)$. All these data indicate that compounds $\mathbf{3}, \mathbf{4}$ and $\mathbf{5}$ have the same structure corresponding to the formula of $\left\{\left[\operatorname{ArNH}\left(\mathrm{CH}_{2}\right)_{3} \mathrm{NAr}\right] \mathrm{Al}(\mu-\mathrm{E})\right\}_{2}$.

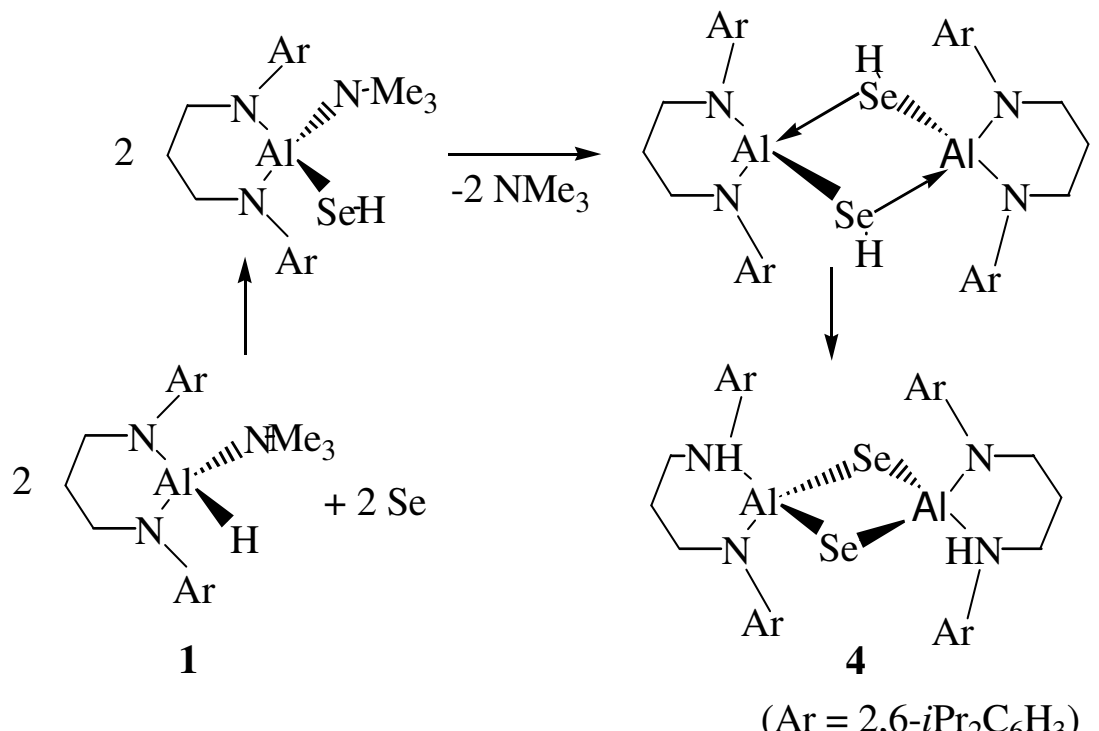

Scheme 5

The reaction of aluminum dihydride with selenium has been discussed in our group, ${ }^{[21,28-29]}$ where the formation of a dimeric compound might proceed through an $\mathrm{Al}-\mathrm{SeH}$ intermediate. In a similar way the reaction of aluminum monohydride $\mathbf{1}$ with selenium might involve the formation of intermediate $\left[\mathrm{ArN}\left(\mathrm{CH}_{2}\right)_{3} \mathrm{NAr}\right] \mathrm{Al}(\mathrm{SeH})\left(\mathrm{NMe}_{3}\right)$, which dimerizes to produce $\left\{\left[\operatorname{ArN}\left(\mathrm{CH}_{2}\right)_{3} \mathrm{NAr}\right] \mathrm{Al}(\mu \text {-SeH})\right\}_{2}$ under elimination of gaseous $\mathrm{NMe}_{3}$. However, with reference to related $\mathrm{Al}-\mathrm{SeH}$ compounds $\mathrm{LAl}(\mathrm{SeH})_{2}$ and $\mathrm{LAl}(\mathrm{SeH}) \mathrm{Se}(\mathrm{SeH}) \mathrm{AlL} \quad(\mathrm{L} \quad=$ $\left.\mathrm{N}(\mathrm{Ar}) \mathrm{C}(\mathrm{Me}) \mathrm{CHC}(\mathrm{Me}) \mathrm{N}(\mathrm{Ar}), \mathrm{Ar}=2,6-i \mathrm{Pr}_{2} \mathrm{C}_{6} \mathrm{H}_{3}\right),{ }^{[56]}$ no absorptions in the range of 2000$2500 \mathrm{~cm}^{-1}$ in the IR spectrum are observed to indicate the formation of an $\mathrm{Al}-\mathrm{SeH}$ moiety. This suggests that the dimer $\left\{\left[\mathrm{ArN}\left(\mathrm{CH}_{2}\right)_{3} \mathrm{NAr}\right] \mathrm{Al}(\mu-\mathrm{SeH})\right\}_{2}$ is not stable under heating and the hydrogen atom attached to selenium atom migrates quickly to one of the nitrogen atoms at the diamide ligand to afford stable compound 4. The most likely mechanism is given in Scheme 5. The formation of compounds 3 and $\mathbf{5}$ might be similar to that of $\mathbf{4}$.

A suitable single crystal of compound $\mathbf{4}$ was measured by X-ray diffraction. The structure analysis of compound $\mathbf{4}$ shows a dimeric species containing two molecules of toluene. 
Unfortunately, the quality of the crystal structure did not allow the location of the hydrogen atoms on the nitrogen atoms. Nevertheless, the presence of NH groups was established by IR and ${ }^{1} \mathrm{H}$ NMR spectroscopy. The molecular structure is viewed in Figure 3 with selected bond lengths and angles. The $\mathrm{Al}(1)-\mathrm{N}(1)(1.932(11) \AA)$ and $\mathrm{Al}(1)-\mathrm{N}(2)(1.916(11) \AA)$ bond distances are midway between the $\mathrm{Al}-\mathrm{N}_{\text {amine }}$ and $\mathrm{Al}-\mathrm{N}_{\text {amido }}$ bond distances observed in complex $\mathrm{AlH}(\mathrm{Cl})\left[t \mathrm{BuNCH}_{2} \mathrm{CH}_{2} \mathrm{~N}(t \mathrm{Bu}) \mathrm{H}\right]^{[37]}(\mathrm{Al}-\mathrm{N}(1)$ (amine) $(2.00(1) \AA$ and $\mathrm{Al}-\mathrm{N}(2)$ (amid

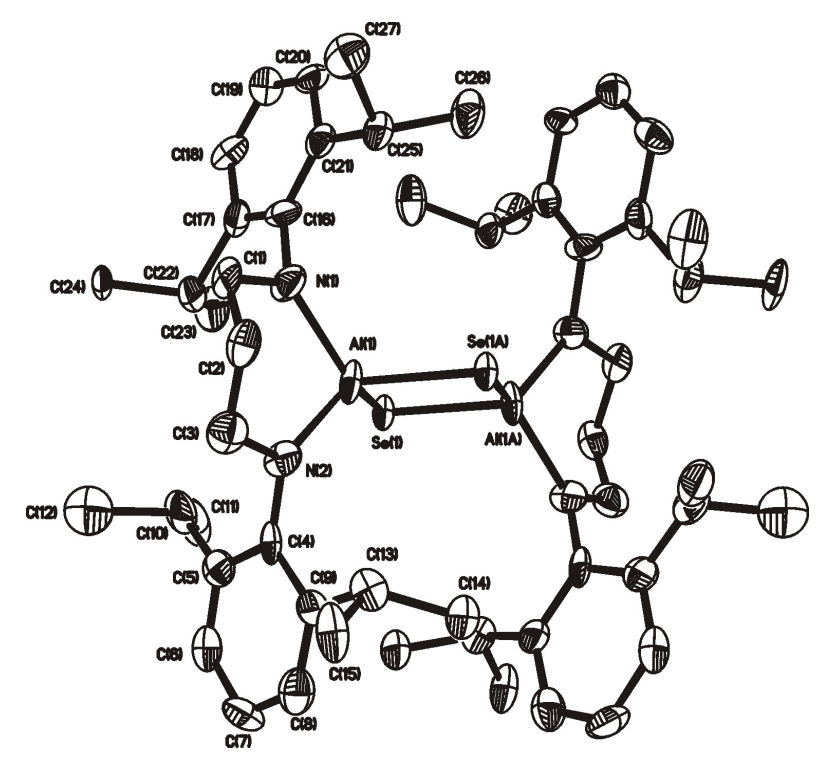

Figure 3. Molecular structure of 4. H atoms are omitted for clarity. Selected bond lengths (A) and angles $\left({ }^{\circ}\right): \mathrm{Al}(1)-\mathrm{N}(1)$ 1.932(11), $\mathrm{Al}(1)-\mathrm{N}(2)$ 1.916(11), $\mathrm{Al}(1)-\mathrm{Se}(1) 2.339(1), \mathrm{Al}(1)-$ $\mathrm{Se}(1 \mathrm{~A})$ 2.381(1), N(1)-Al(1)-N(2) 98.13(14), $\mathrm{Se}(1)-\mathrm{Al}(1)-\mathrm{Se}(1 \mathrm{~A})$ 101.44(5).

-o) (1.80(1) $\AA$ ), and are longer than those Al-N distances found in compound $\mathrm{Al}\left[t \mathrm{BuNCH}_{2} \mathrm{CH}_{2} \mathrm{~N}(t \mathrm{Bu})\right]\left[t \mathrm{BuNCH}_{2} \mathrm{CH}_{2} \mathrm{NH}(t \mathrm{Bu})\right]^{[38]}$ in which the unique amine nitrogen center is disordered over all four nitrogen centers (1.850(5), 1.870(5) $\mathrm{A})$, and much longer than $\mathrm{Al}-\mathrm{N}_{\text {amido }}$ distances in $\mathbf{1}(1.820(1), 1.828(1) \AA)$ and 2 (1.804(2), 1.810(2) $\left.\mathrm{A}\right)$. However, compared to compound $\mathrm{AlH}(\mathrm{Cl})\left[t \mathrm{BuNCH}_{2} \mathrm{CH}_{2} \mathrm{~N}(t \mathrm{Bu}) \mathrm{H}\right],{ }^{[37]}$ where the remarkable difference $(0.20 \AA$ ) between $\mathrm{Al}-\mathrm{N}(1)$ (amine) and $\mathrm{Al}-\mathrm{N}(2)$ (amido) was observed, the very slight difference $(0.016 \AA$ ) between $\mathrm{Al}(1)-\mathrm{N}(1)$ and $\mathrm{Al}(1)-\mathrm{N}(2)$ in 4 may imply the disorder of the two hydrogen atoms over the sides of all four nitrogen centers. Moreover, the similar 
coordinated environments and approximately planar co-ordination geometries at the N(1) and $\mathrm{N}(2)$ (at $\mathrm{N}(1), \mathrm{Al}(1)-\mathrm{N}(1)-\mathrm{C}(1) 119.6(8)^{\circ}, \mathrm{Al}(1)-\mathrm{N}(1)-\mathrm{C}(16) 126.4(8)^{\circ}, \mathrm{C}(1)-\mathrm{N}(1)-\mathrm{C}(16)$ $113.2(9)^{\circ}, \sum(\mathrm{C}-\mathrm{N}-\mathrm{Al}, \mathrm{C})=359.2^{\circ} ;$ at $\mathrm{N}(2), \mathrm{Al}(1)-\mathrm{N}(2)-\mathrm{C}(3) 121.1(9)^{\circ}, \mathrm{Al}(1)-\mathrm{N}(2)-\mathrm{C}(4)$ $\left.130.1(7)^{\circ}, \mathrm{C}(3)-\mathrm{N}(2)-\mathrm{C}(4) 108.0(9)^{\circ}, \sum(\mathrm{C}-\mathrm{N}-\mathrm{Al}, \mathrm{C})=359.2^{\circ}\right)$ do not allow to distinguish between the amine nitrogen and the amido nitrogen centers. Overall, it is assumed that the almost equal possibility of the hydrogen migration from the selenium atom to any nitrogen atom at the diamide ligand is included in the course of the reaction.

The $\mathrm{Al}_{2} \mathrm{Se}_{2}$ core exhibits an ideal planar ring (the least-square deviation $\Delta=0.0005$ ) with $\mathrm{Al}(1)-\operatorname{Se}(1)$ of $2.339(1) \AA ⿻ \quad \mathrm{Al}(1)-\operatorname{Se}(1 \mathrm{~A})$ of $2.381(1) \AA$ and $\mathrm{Al}(1)-\operatorname{Se}(1)-\mathrm{Al}(1 \mathrm{~A})$ of $78.56(5)^{\circ}$, which are as expected in a range for $\mathrm{Al}_{2} \mathrm{Se}_{2}$ core compounds, ${ }^{[22-23,28-29]}$ while the $\mathrm{Al}(1)-\mathrm{Se}(1)$ and $\mathrm{Al}(1)-\mathrm{Se}(1 \mathrm{~A})$ distances differ by ca. $0.042 \AA$ probably due to steric effects of the backbone ligand toward the $\mathrm{Al}_{2} \mathrm{Se}_{2}$ ring. The ligand chelates the $\mathrm{Al}$ atom to fuse two sixmembered $\mathrm{AlN}_{2} \mathrm{C}_{3}$ rings, which are arranged in trans on each side of $\mathrm{Al}_{2} \mathrm{Se}_{2}$ core. The two $\mathrm{AlN}_{2} \mathrm{C}_{3}$ rings both display a boat conformation with $\mathrm{Al}(1)$ and $\mathrm{Al}(1 \mathrm{~A})$ at the bow and $\mathrm{C}(2)$ and $\mathrm{C}(2 \mathrm{~A})$ at the stern, respectively, and are almost arranged perpendicularly to the $\mathrm{Al}_{2} \mathrm{Se}_{2}$ ring (the dihedral angle between the ring $\left(\mathrm{Al}_{2} \mathrm{Se}_{2}\right)$ and the plane $(\mathrm{N}(1)-\mathrm{N}(2)-\mathrm{C}(3)-\mathrm{C}(1), \Delta=$ $0.0238 \AA$ ) is $90.5^{\circ}$ ).

Thus, it has been shown that the $\left[\mathrm{ArN}\left(\mathrm{CH}_{2}\right)_{3} \mathrm{NAr}\right]^{2-}$ ligand forms a stable chelate with the aluminum hydride. The hydride functionally can be replaced by a fluorine atom or substituted by a chalcogen $(\mathrm{S}, \mathrm{Se}, \mathrm{Te})$ under migration of the hydrogen to an adjacent nitrogen of the chelating ring. The latter reaction does not yield an aluminum chalcogen double bond system but rather a four-membered ring of composition $\mathrm{Al}_{2} \mathrm{E}_{2}(\mathrm{E}=\mathrm{S}, \mathrm{Se}, \mathrm{Te})$. 


\subsection{The Stepwise Hydrolysis of Aluminum Chloride \\ Iodide LAICII in the Presence of $N$-Heterocyclic \\ Carbene as Hydrogen Halide Acceptor}

Abstract: An aluminum chloride iodide $\operatorname{LAlClI}\left(7, \mathrm{~L}=\mathrm{HC}[(\mathrm{CMe})(\mathrm{NAr})]_{2}, \mathrm{Ar}=2,6-i \mathrm{Pr}_{2} \mathrm{C}_{6} \mathrm{H}_{3}\right)$ has been synthesized to study the stepwise hydrolysis of this compound in the presence of 1,3diisopropyl-4,5-dimethylimidazol-2-ylidene as hydrogen halide acceptor. The isolation and characterization of the aluminum chloride hydroxide $[\mathrm{LAlCl}(\mu-\mathrm{OH})]_{2}(8)$ and the dihydroxide $\mathrm{LAl}(\mathrm{OH})_{2}(9)$ demonstrate the realization of a controlled hydrolysis.

The controlled hydrolysis of organoaluminum compounds is of great interest since it can lead to the formation of alumoxanes which are used as active catalysts and cocatalysts for the polymerization of a wide range of organic monomers. ${ }^{[8-16,57-59]}$ Furthermore, it can be useful to generate organoaluminum hydroxides, oxides, or oxide hydroxides. ${ }^{[12,57-58,60-65]}$ On one hand, the reaction of $\mathrm{AlR}_{3}$ compounds $(\mathrm{R}=\mathrm{Me}, t \mathrm{Bu} \text {, Mes, or } \mathrm{Ph})^{[66-67]}$ with water or hydrated inert salts afforded some aggregated alumoxanes $[\mathrm{RAlO}]_{\mathrm{n}}$, aluminum hydroxides, and oxide hydroxides. On the other hand, it has been shown that aluminum hydrides, ${ }^{[71-72]}$ alkyls, ${ }^{[73]}$ or aluminum amino-amides ${ }^{[74]}$ stabilized by bulky organic ligands can be used as precursor for the synthesis of organoalumoxanes, organoalumoxane hydrides, and hydroxides by employing $\mathrm{H}_{2} \mathrm{O}$, or water-containing compounds (for example, $\left.\mathrm{H}_{2} \mathrm{O} \cdot \mathrm{B}\left(\mathrm{C}_{6} \mathrm{~F}_{5}\right)_{3}\right)$. In most cases the bulky ligand at the aluminum center hinders the aggregation of the hydrolysis products. However it has an effect on the stabilization of the metal whether electronically or sterically, and can result in the formation of unusual complexes, such as $\mathrm{L}^{\prime} \mathrm{Al}=\mathrm{O} \cdot \mathrm{B}\left(\mathrm{C}_{6} \mathrm{~F}_{5}\right)_{3}\left(\mathrm{~L}^{\prime}=\right.$ $\left.\mathrm{Et}_{2} \mathrm{NCH}_{2} \mathrm{CH}_{2} \mathrm{NC}(\mathrm{Me}) \mathrm{CHC}(\mathrm{Me}) \mathrm{NCH}_{2} \mathrm{CH}_{2} \mathrm{NEt}_{2}\right) .{ }^{[73]}$ More recently, we have reported the reaction of $\mathrm{LAlI}_{2}\left(\mathrm{~L}=\mathrm{HC}[(\mathrm{CMe})(\mathrm{NAr})]_{2}, \mathrm{Ar}=2,6-i \mathrm{Pr}_{2} \mathrm{C}_{6} \mathrm{H}_{3}\right)$ with $\mathrm{KOH}$ containing a small amount of $\mathrm{H}_{2} \mathrm{O}$ and $\mathrm{KH}$ in a liquid ammonia/toluene two-phase system and successfully isolated the first terminal aluminum dihydroxide $\mathrm{LAl}(\mathrm{OH})_{2}$ supported by the bulky $\mathrm{L}$ ligand. ${ }^{[75]}$ An improved route to $\mathrm{LAl}(\mathrm{OH})_{2}$ was realized by using a strong nucleophilic 
reagent, $N$-heterocyclic carbene as a $\mathrm{HCl}$ acceptor for the reaction of $\mathrm{LAlCl}_{2}$ and stoichiometric amounts of water. $^{[76]}$ In the course of the synthesis of $\mathrm{LAl}(\mathrm{OH})_{2}$ from $\mathrm{LAl}(\mathrm{Hal})_{2}(\mathrm{Hal}=\mathrm{I}, \mathrm{Cl})$, a stepwise process was proposed. ${ }^{[75]}$ However, there was no experimental evidence for the formation of $\mathrm{LAl}(\mathrm{OH}) \mathrm{Cl}$ or $\mathrm{LAl}(\mathrm{OH}) \mathrm{I}$ as an intermediate. In this context we report on the preparation of aluminum chloride iodide LAlCII (7) and its stepwise reaction with water by using a $N$-heterocyclic carbene as hydrogen halide acceptor, as well as isolation of the intermediate $[\mathrm{LAlCl}(\mu-\mathrm{OH})]_{2}(\mathbf{8})$.
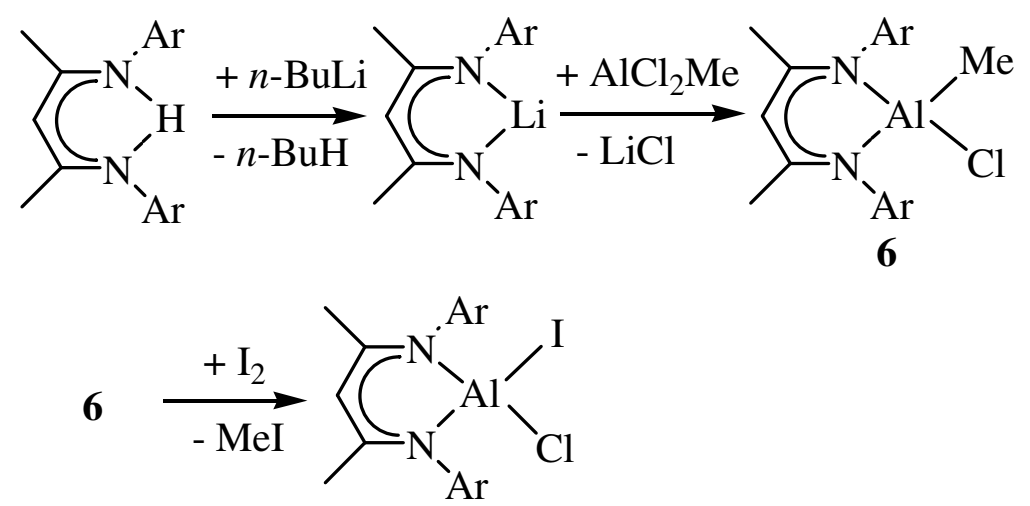

7

$$
\mathrm{Ar}=2,6-i \mathrm{Pr}_{2} \mathrm{C}_{6} \mathrm{H}_{3}
$$

\section{Scheme 6}

The toluene/ $n$-hexane solution of LLi prepared from LH and $n$-BuLi was directly used for the reaction with $\mathrm{AlCl}_{2} \mathrm{Me}$. Compound $\mathrm{LAlClMe}(\mathbf{6})$ was obtained as crystalline solid, its composition was confirmed by EI-mass and ${ }^{1} \mathrm{H}$ NMR measurements as well as by elemental analysis. The reaction of 6 with one equiv of $\mathrm{I}_{2}$ within 5 days at room temperature resulted in the formation of compound LAlCII (7) as very light yellow crystals (Scheme 6). Compound 7 melts at $200-203{ }^{\circ} \mathrm{C}$ and the EI-mass spectrum indicates its monomeric nature in the gas phase $\left(m / z(\%): 606\left(1,\left[M^{+}\right]\right), 571\left(4,\left[M^{+}-\mathrm{Cl}\right], 479\left(100,\left[M^{+}-\mathrm{I}\right]\right)\right.\right.$. The ${ }^{1} \mathrm{H}$ NMR spectrum of 7 shows two separated groups of septets $(3.28,3.64 \mathrm{ppm})$ and four groups of doublets $(1.02,1.12,1.41,1.42 \mathrm{ppm})$ for the respective isopropyl methine and methyl proton resonances of the Ar substituents, evidencing the asymmetric steric environment of the Ar isopropyl groups induced by $\mathrm{Al}-\mathrm{Cl}$ and $\mathrm{Al}-\mathrm{I}$. 
The X-ray crystal structural analysis of 7 showed a mononuclear compound with an aluminum center coordinated to the chelating $\beta$-diketiminato ligand and one $\mathrm{Cl}$ and one $\mathrm{I}$ atom in a distorted tetrahedral geometry. The molecular structure of $\mathbf{7}$ is shown in Figure 4 with selected bond lengths and angles. The terminal Al-I bond length (2.473(1) A) is a little

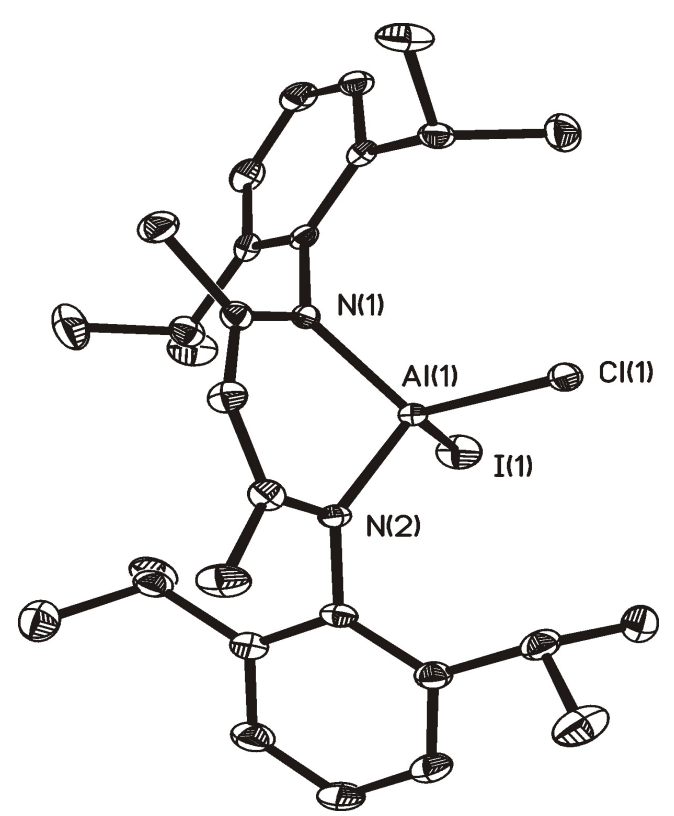

Figure 4. Molecular structure of 7. H atoms are omitted for clarity. Selected bond lengths $(\AA)$ and angles $\left(^{\circ}\right)$ : $\mathrm{Al}(1)-\mathrm{N}(1)$ 1.879(3), $\mathrm{Al}(1)-\mathrm{N}(2)$ 1.863(3), $\mathrm{Al}(1)-\mathrm{Cl}(1) 2.151(1), \mathrm{Al}(1)-\mathrm{I}(1)$

$$
\text { 1.473(1), N(1)-Al(1)-N(2) 100.04(12), Cl(1)-Al(1)-I(1) 111.82(6). }
$$

shorter than those in $\mathrm{LAlI}_{2}(2.501(3), 2.543(3) \AA),{ }^{[77]}$ and close to those in $[\operatorname{RAlI}(\mu-\mathrm{I})]_{2}(\mathrm{R}=$ 2,6-i $\left.\mathrm{Pr}_{2} \mathrm{C}_{6} \mathrm{H}_{3} \mathrm{~N}\left(\mathrm{SiMe}_{3}\right)\right)(2.464(2) \AA) .{ }^{[78]}$ The $\mathrm{Al}-\mathrm{Cl}$ distance $(2.151(1) \AA)$ is in good agreement with those in the terminal aluminum chlorides $\left[3,5-t \mathrm{Bu}_{2} \mathrm{NCH}=\mathrm{C}\left(\mathrm{SiMe}_{3}\right) \cdot \mathrm{pz}\right] \mathrm{AlCl}_{2}$ $(2.135(1) \quad \AA), \quad\left[3,5-t \mathrm{Bu}_{2} \mathrm{NCH}=\mathrm{C}\left(\mathrm{SiMe}_{3}\right) \cdot \mathrm{pz}\right] \mathrm{AlCl}\left(3,5-t \mathrm{Bu}_{2} \mathrm{pz}\right) \quad(2.153(1) \quad \AA),{ }^{[79]} \quad$ and $\left[\left(\mathrm{C}_{7} \mathrm{H}_{13} \mathrm{~N}_{2}\right) \mathrm{AlCl}\right]_{2}(\mu-\mathrm{O})(2.164(1) \AA) .{ }^{[65]}$

The stepwise hydrolysis of compound 7 was first carried out with one equiv of $\mathrm{H}_{2} \mathrm{O}$ in the presence of one equiv of 1,3-diisopropyl-4,5-dimethylimidazol-2-ylidene (abbreviated as :C) in toluene solution from $0{ }^{\circ} \mathrm{C}$ to room temperature (Scheme 7). The removal of solvent in vacuo followed by extraction with $n$-hexane gave partial hydrolysis product $[\mathrm{LAlCl}(\mu-\mathrm{OH})]_{2}$ (8) in $70 \%$ yield. The mass spectrum of $\mathbf{8}$ indicates the monomeric composition $(\mathrm{m} / \mathrm{z}(\%)$ : 
$496.3\left(50,\left[M^{+} / 2\right]\right), 478.3\left(16,\left[M^{+} / 2-\mathrm{OH}-1\right], 461.3\left(100,\left[M^{+} / 2-\mathrm{Cl}\right]\right)\right.$. However the ${ }^{1} \mathrm{H}$ NMR spectrum of 8 recorded at 200.13 MHz shows one septet (3.40 ppm) for the isopropyl methine resonances of the Ar substituents, while two groups of incompletely separated septets $(3.42,3.47 \mathrm{ppm})$ were observed at 500.13 MHz. These are markedly different from those observed in the NMR spectrum of compound $7(3.28,3.64 \mathrm{ppm})$ and imply a possible oligom

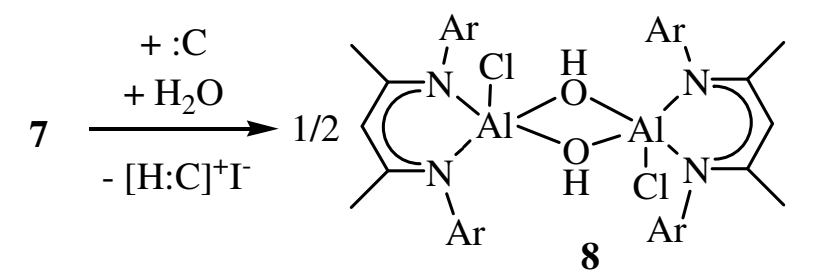

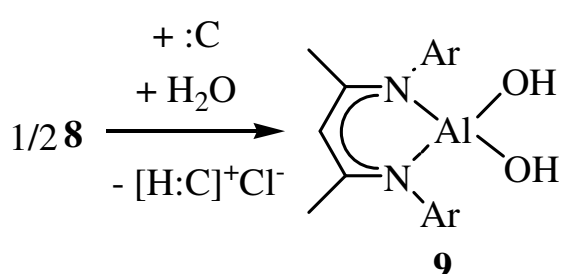

$$
\begin{aligned}
& 9 \quad \mathrm{Ar}=2,6-i \mathrm{Pr}_{2} \mathrm{C}_{6} \mathrm{H}_{3} \\
& : \mathrm{C}=\left[\mathrm{CN}(i \operatorname{Pr}) \mathrm{C}_{2} \mathrm{Me}_{2} \mathrm{~N}(i \mathrm{Pr})\right]
\end{aligned}
$$

Scheme 7

-erization in solution. One singlet at 0.72 (in $\mathrm{C}_{6} \mathrm{D}_{6}$ ) alternatively 0.69 (in $\mathrm{D}_{8}$-toluene) ppm could be assigned to the $\mathrm{Al}-\mu-\mathrm{OH}$ proton resonance comparable to the $\beta$-diketiminato aluminum dihydroxide $\mathrm{LAl}(\mathrm{OH})_{2}(0.22 \mathrm{ppm}) .{ }^{[76]}$ One broad absorption centered at $3459 \mathrm{~cm}^{-1}$ corresponds to $v_{\mathrm{OH}}$ in the IR spectrum of $\mathbf{8}$.

The X-ray structural analysis unambiguously confirms compound $\mathbf{8}$ as a dimer in the solid state which is consistent with its solution behavior however in contrast to the EI-mass spectral results. The molecular structure of $\mathbf{8}$ is depicted in Figure 5 with selected bond lengths and angles. Each $\mathrm{Al}$ center is coordinated to one $\beta$-diketiminato ligand, one $\mathrm{Cl}$, and two $\mathrm{OH}$ groups and adopts a distorted tetragonal-pyramidal geometry with the $\mathrm{Cl}$ atom located at the apical position and $2 \mathrm{~N}$ and $2 \mathrm{O}$ atoms forming the basal plane (the least square plane $\Delta=$ $0.012 \AA$ ). The $\mathrm{Al}_{2} \mathrm{O}_{2}$ core is a perfectly planar four-membered ring due to the symmetry. The two $\mathrm{H}$ atoms of the $\mathrm{OH}$ groups are located within this plane $(\Delta=0.009 \AA)$. The $\mathrm{Al}-\mathrm{OH}$ bond lengths $(1.875(1), 1.886(1) \AA$ ) fall within the range of 1.787(3)-2.086(4) $\AA$ observed for 
bridging aluminum hydroxides, ${ }^{[66-70]}$ and are longer than the terminal ones in $\operatorname{LAl}(\mathrm{OH})_{2}$ (1.697 (2) and $1.711(2) \AA)^{[75]}$ and $[\mathrm{LAl}(\mathrm{OH})]_{2}(\mu-\mathrm{O})(1.738(3) \text { and } 1.741(3) \AA)^{[80]}$ The two $\mathrm{Al}-\mathrm{Cl}$ bonds are in trans position arranged toward the $\mathrm{Al}_{2} \mathrm{O}_{2} \mathrm{H}_{2}$ plane with bond distances (2.190(1) A) slightly longer than that in 7 .

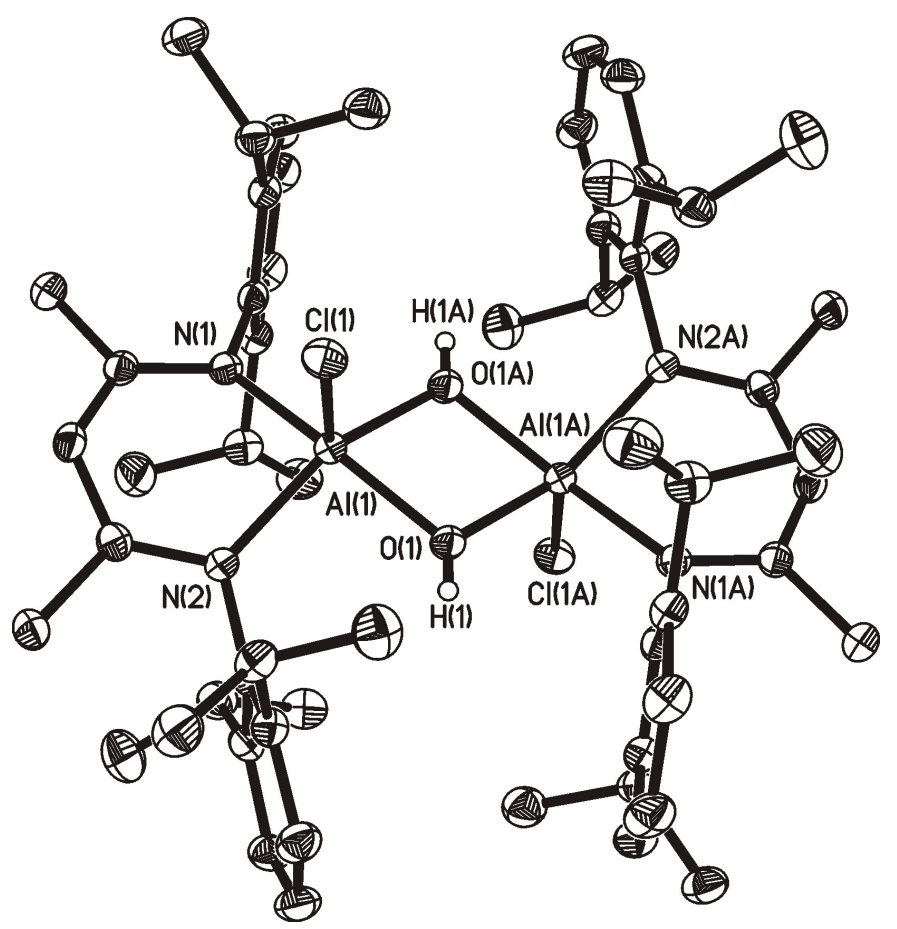

Figure 5. Molecular structure of $\mathbf{8}$. H atoms in L are omitted for clarity. Selected bond lengths $(\AA)$ and angles $\left(^{\circ}\right)$ : $\mathrm{Al}(1)-\mathrm{N}(1)$ 1.977(1), $\mathrm{Al}(1)-\mathrm{N}(2)$ 1.984(1), $\mathrm{Al}(1)-\mathrm{Cl}(1) 2.189(1), \mathrm{Al}(1)-$ $\mathrm{O}(1)$ 1.875(1), $\mathrm{Al}(1)-\mathrm{O}(1 \mathrm{~A}) 1.886(1), \mathrm{N}(1)-\mathrm{Al}(1)-\mathrm{N}(2) 90.05(6), \mathrm{O}(1)-\mathrm{Al}(1)-\mathrm{O}(1 \mathrm{~A})$

$$
\text { 72.46(7), N(1)-Al(1)-Cl(1) 92.91(6), N(2)-Al(1)-Cl(1) 100.90(5). }
$$

Attempts to obtain monomeric $\mathbf{8}$ by recrystallization from THF or by the use of THF as a solvent during the preparation were not successful, only the dimer $\mathbf{8}$ being formed. This behavior demonstrates the strong Lewis-acidic $\mathrm{Al}$ center in the monomeric $\mathrm{LAlCl}(\mathrm{OH})$ which leads to an association despite of the bulky ligand. This is in contrast to the monomeric species LAlMe $2,{ }^{[81]} \mathrm{LAlI}_{2},{ }^{[77]} \mathrm{LAl}\left(\mathrm{NH}_{2}\right)_{2},{ }^{[76]} \mathrm{LAlMe}(\mathrm{OH})$, and LAlClI.

It is interesting to mention that a direct interaction between 7 and $N$-heterocyclic carbene :C in THF solvent results in the generation of $[\mathrm{H}: \mathrm{C}]^{+} \mathrm{I}^{-}$as insoluble microcrystals, indicating the capability of proton abstraction of : $\mathbf{C}$ from the $\beta$-diketiminato ligand. (Analytic data for 
compound $[\mathrm{H}: \mathrm{C}]^{+} \mathrm{I}^{-}$: M.p. $173-174{ }^{\circ} \mathrm{C} ;{ }^{1} \mathrm{H}$ NMR $\left(500.13 \mathrm{MHz}, \mathrm{CD}_{3} \mathrm{CN}, 298 \mathrm{~K}, \mathrm{ppm}\right): \delta 1.51$ $\left(\mathrm{d}, 4 \times 3 \mathrm{H},{ }^{3} J_{\mathrm{HH}}=6.7 \mathrm{~Hz}, \mathrm{CH}\left(\mathrm{CH}_{3}\right)_{2}\right), 2.23\left(\mathrm{~s}, 2 \times 3 \mathrm{H}, \mathrm{C}\left(\mathrm{CH}_{3}\right)\right), 4.49\left(\mathrm{sept}, 2 \times 1 \mathrm{H},{ }^{3} J_{\mathrm{HH}}=\right.$ $\left.6.7 \mathrm{~Hz}, \mathrm{CH}\left(\mathrm{CH}_{3}\right)_{2}\right), 8.63$ (s, $\left.1 \mathrm{H}, H: \mathrm{C}\right)$; EI-MS m/z (\%): 181 (100, [H:C] $\left.{ }^{+}\right), 128\left(20,\left[\mathrm{I}^{-}\right]\right)$; Anal. Calcd for $\mathrm{C}_{11} \mathrm{H}_{21} \mathrm{IN}_{2}(M r=308.1)$ : C, 42.87; H, 6.87; N, 9.09; I, 41,17. Found: C, 43.19; $\mathrm{H}, 6.83 ; \mathrm{N}, 8.95 ; \mathrm{I}, 40.45)$. The proton source of $[\mathrm{H}: \mathrm{C}]^{+} \mathrm{I}^{-}$might come from the $\beta$-methyl groups of the L ligand backbone. ${ }^{[82-84]}$ Reference experiment of :C with $\mathrm{H}_{2} \mathrm{O}$ in $\mathrm{THF}$ monitored by the ${ }^{1} \mathrm{H}$ NMR spectrum shows no characteristic resonance for $[\mathrm{H}: \mathbf{C}]^{+}$, and therefore indicates the incapability of : $\mathbf{C}$ to abstract a proton from uncoordinated $\mathrm{H}_{2} \mathrm{O}$. Accordingly we assume that the formation of $\mathbf{8}$ from the reaction of $\mathbf{7}, \mathbf{:}$, and $\mathrm{H}_{2} \mathrm{O}$ may proceed through the initial coordination of $\mathrm{H}_{2} \mathrm{O}$ to aluminum (Scheme 8). This assumption is in accordance with the formation of $\mathrm{Al}\left(\mathrm{OH}_{2}\right)_{6} \mathrm{Cl}_{3}$ from $\mathrm{AlCl}_{3}$ by adding controlled amounts of water. ${ }^{[85]}$ Comparable examples are the triarylaluminum water adduct $\mathrm{Mes}_{3} \mathrm{Al} \cdot \mathrm{OH}_{2} \cdot \mathrm{nTHF}^{[69]}$ and the structurally characterized $\left(\mathrm{C}_{6} \mathrm{~F}_{5}\right)_{3} \mathrm{Al} \cdot \mathrm{OH}_{2} \cdot{ }^{[86]}$ The coordinated $\mathrm{H}_{2} \mathrm{O}$ in $\mathbf{A}$ is deprotonated by : $\mathbf{C}$ to give the cation $[\mathrm{H}: \mathbf{C}]^{+}$which subsequently combines with $\mathrm{I}^{-}$to form the insoluble $[\mathrm{H}: \mathbf{C}]^{+} \mathrm{I}^{-}$. The generation of $[\mathrm{H}: \mathbf{C}]^{+} \mathrm{I}^{-}$rather than $[\mathrm{H}: \mathbf{C}]^{+} \mathrm{Cl}^{-}$apparently indicates the easier removal of $\mathrm{I}^{-}$compared to that of $\mathrm{Cl}^{-}$.

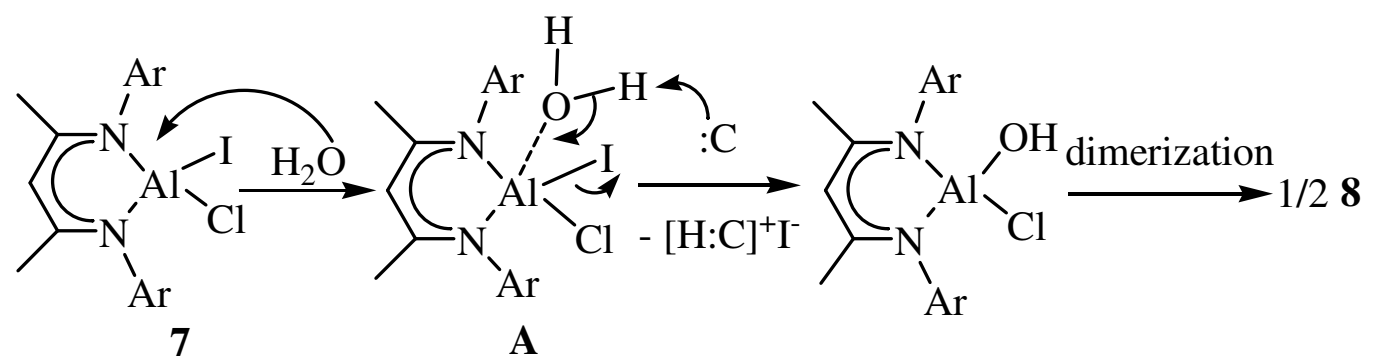

$$
\mathrm{Ar}=2,6-i \mathrm{Pr}_{2} \mathrm{C}_{6} \mathrm{H}_{3},: \mathrm{C}=\left[\mathrm{CN}(i \operatorname{Pr}) \mathrm{C}_{2} \mathrm{Me}_{2} \mathrm{~N}(i \mathrm{Pr})\right]
$$

\section{Scheme 8}

Further hydrolysis of $\mathbf{8}$ was accomplished with two equiv of $\mathrm{H}_{2} \mathrm{O}$ and : $\mathbf{C}$ (Scheme 7). As expected the aluminum dihydroxide $\mathrm{LAl}(\mathrm{OH})_{2}(\mathbf{9})$ was formed, however in a relatively low yield $(25 \%)$. Such low yield might be due to the complete hydrolysis of partial $\mathbf{8}$, which resulted in an insoluble aluminum oxide or hydroxide, and $\mathrm{HL},{ }^{[75]}$ although a high yield was 
achieved by the direct hydrolysis of $\mathrm{LAlCl}_{2}$ in the presence of $\mathbf{: C} .^{[76]}$ The hydrolytic procedure to 9 is similar to that for the conversion of $\mathbf{7}$ to $\mathbf{8}$, but undergoes during the reaction a dissociation from dimeric $\mathbf{8}$ to monomeric $\mathbf{9}$ compared to an association from monomeric $\mathbf{7}$ to dimeric $\mathbf{8}$ in the first step of the hydrolysis.

Thus, the synthesis of compound LAlCII (7) and its stepwise hydrolysis in the presence of 1,3-diisopropyl-4,5-dimethylimidazol-2-ylidene (:C) has been described. The difference in the bond strength of $\mathrm{Al}-\mathrm{I}$ and $\mathrm{Al}-\mathrm{Cl}^{[87]}$ allows the controlled stepwise hydrolysis. The deprotonation of the coordinated $\mathrm{H}_{2} \mathrm{O}$ by :C under the formation of the insoluble $[\mathrm{H}: \mathbf{C}]^{+} \mathrm{I}^{-}$or $\left[\mathrm{H}: \mathrm{C}^{+} \mathrm{Cl}^{-}\right.$salts leads to $[\mathrm{LAlCl}(\mu-\mathrm{OH})]_{2}(\mathbf{8})$ and $\mathrm{LAl}(\mathrm{OH})_{2}(\mathbf{9})$, respectively, and demonstrates the powerful acceptor properties of the $N$-heterocyclic carbene. Accordingly, we were able to confirm this stepwise process, since there are no structural characterized precedents known containing the $\mathrm{Al}(\mathrm{OH}) \mathrm{Cl}$ moiety, although this type of intermediate is assumed in any hydrolysis product of $\mathrm{AlCl}_{3}$. However the stepwise hydrolysis from $\mathbf{7}$ to $\mathbf{8}$ and finally to $\mathbf{9}$ is accompanied by an association followed by a dissociation process of $\mathrm{LAlCl}(\mathrm{OH})$ species. This observation is beyond our proposal during the direct hydrolysis of $\mathrm{LAl}(\mathrm{Hal})_{2}(\mathrm{Hal}=\mathrm{I}$, Cl) to $9,{ }^{[75]}$ although it is not clear whether this pathway is involved in the latter formation. This may reflect the complexity of the stepwise hydrolysis process. Moreover the advantage of the $[\mathrm{H}: \mathrm{C}]^{+} \mathrm{X}^{-}(\mathrm{X}=\mathrm{Cl}, \mathrm{I})$ is that it can be completely recovered by filtration and in the presence of a strong base such as $t \mathrm{BuOK}$ quantitatively recycled to the $N$-heterocyclic carbene. This method of hydrolysis in the presence of $N$-heterocyclic carbene will be further applied to the preparation of Brönsted acidic sensitive systems. ${ }^{[85]}$ Compound $\mathbf{8}$ contains Al$\mathrm{Cl}$ and $\mathrm{Al}-\mathrm{OH}$ functionalities, of which the former can react by metathesis, and the $\mathrm{OH}$ acting as a Brönsted acidic proton has been documented. ${ }^{[80]}$ Further investigations on the functional reactions of $\mathbf{8}$ are in progress. 


\subsection{The Oxidative Reaction of Aluminum(I) Monomer LAl}

\section{with Molecular Oxygen: A New Approach to Alumoxane}

Abstract: An alumoxane $[\mathrm{LAlO}]_{2}$ (10) has been prepared from the oxidative reaction of aluminum(I) monomer $\mathrm{LAl}\left(\mathrm{L}=\mathrm{HC}[(\mathrm{CMe})(\mathrm{NAr})]_{2}, \mathrm{Ar}=2,6-i \mathrm{Pr}_{2} \mathrm{C}_{6} \mathrm{H}_{3}\right)$ with molecular oxygen. The intense contacts of the $\mathrm{Al}_{2}(\mu-\mathrm{O})_{2}$ unit bring the two oriented $L$ closer together and causes a steric strain resulting in $C-H \cdots \pi$ interactions between one isopropyl group of one $\mathrm{L}$ and the aryl ring of another $L$. Further reaction of 10 with one equiv of $\mathrm{H}_{2} \mathrm{O}$ resulted in the formation of an alumoxane hydroxide $[\mathrm{LAl}(\mathrm{OH})]_{2}(\mu-\mathrm{O})(11)$, indicating a strain releasing process of 10. An isomer of 10, a $\mathrm{C}-\mathrm{H}$ activatied aluminum hydroxide 13, however, was obtained from the hydrolysis of a $\mathrm{C}-\mathrm{H}$ activated large bulky aluminium amide $\mathbf{1 2}$.

There is great interest in alumoxanes since they can be used as active catalysts in the polymerization of epoxides, aldehydes, and olefins. ${ }^{[8-14]}$ Furthermore, methylalumoxane (MAO) functioning as a highly active cocatalyst for group 4 metallocenes catalyzing ethylene and propylene polymerization ${ }^{[15-16]}$ has been of remarkable industrial importance. In general, alumoxanes of formula $[\mathrm{RAlO}]_{\mathrm{n}}$ or $\left[\mathrm{R}_{2} \mathrm{AlOAlR}\right]_{\mathrm{n}}(\mathrm{R}=$ organic group $)$ can be synthesized by the controlled hydrolysis of organoaluminum(III) compounds using water, or water containing metal salts, ${ }^{[66-67]}$ and alternatively by the reaction of those compounds with oxygen containing species such as $\mathrm{CO}_{2},{ }^{[62]} \mathrm{RCONR}_{2},{ }^{[67]} \mathrm{MeCO}_{2} \mathrm{H},{ }^{[88]} \mathrm{PbO},{ }^{[89]}$ and $\left[\mathrm{Me}_{2} \mathrm{SiO}_{3}{ }^{[63]}\right.$ The reaction of $\mathrm{R}_{2} \mathrm{AlAlR}_{2}\left(\mathrm{R}=\mathrm{CH}\left(\mathrm{SiMe}_{3}\right)_{2}\right)$ with $\mathrm{Me}_{2} \mathrm{SO}$ generates the alumoxane $\mathrm{R}_{2} \mathrm{AlOAlR}_{2} \cdot{ }^{[90]}$ Alkylaluminum(III) compounds reacting with $\mathrm{O}_{2}$ often undergo insertion reaction into the $\mathrm{Al}-$ alkyl bond and result in the formation of aluminum alkoxides and alkylperoxides. ${ }^{[5,91-94]}$ In contrast, the reaction of organoaluminum(I) compounds with $\mathrm{O}_{2}$ could lead to the oxidation of the aluminum center to yield alumoxane. Herein, we report on the reaction of aluminum(I) monomer $\mathrm{LAl}\left(\mathrm{L}=\mathrm{HC}[(\mathrm{CMe})(\mathrm{NAr})]_{2}, \mathrm{Ar}=2,6-i \mathrm{Pr}_{2} \mathrm{C}_{6} \mathrm{H}_{3}\right)^{[95]}$ with molecular oxygen and the isolation of an alumoxane $\left[\mathrm{LAlO}_{2}\right.$ (10). 10 is further hydrolyzed to form alumoxane hydroxide $[\mathrm{LAl}(\mathrm{OH})]_{2}(\mu-\mathrm{O})(\mathbf{1 1})$. 
The toluene solution of $\mathrm{LAl}$ in the presence of $\mathrm{O}_{2}$ between $-78^{\circ} \mathrm{C}$ and room temperature, under stirring, changed slowly the color from red to orange, to yellow, and finally to almost colorless. At ca. $-15^{\circ} \mathrm{C} \mathbf{1 0}$ separated from the solution as a colorless crystalline solid (Scheme 9). The reaction of LAl with $\mathrm{O}_{2}$ might proceed via an aluminum peroxide intermediate $\left(\mathrm{LAlO}_{2}\right)$, which further reacts with another molecule of LAl to afford 10. It has been demonstrated that in the photolytically induced reactions of $\mathrm{AlX} / \mathrm{O}_{2}$ and $(\mathrm{AlX})_{2} / \mathrm{O}_{2}$, an alumin

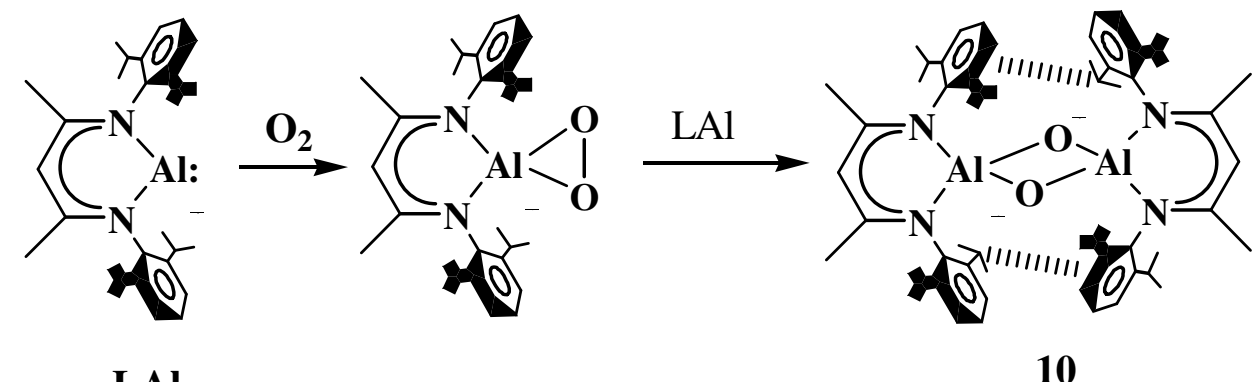

LAl

Scheme 9

-um peroxide $\mathrm{XAlO}_{2}$ was mainly detected for the former and an oxide $\mathrm{XAl}(\mu-\mathrm{O})_{2} \mathrm{AlX}$ for the latter system by means of IR spectroscopy supported by quantum chemical calculations. ${ }^{[96-97]}$ The formation of $\mathrm{XAl}(\mu-\mathrm{O})_{2} \mathrm{AlX}$ was proposed via an $\mathrm{Al}(\mu-\mathrm{X})_{2} \mathrm{AlO}_{2}$ intermediate. Moreover, peroxo complexes are also considered as potential intermediates or products during the oxidation of metals or metal clusters. ${ }^{[98-99]}$ The occurance of this reaction at low temperatures indicates the high reactivity of LAl. The kinetic stabilization of LAl by ligand L allows its uncomplete oxidation in the range of $-78{ }^{\circ} \mathrm{C}$ to room temperature and generates $\mathbf{1 0}$ rather than the inorganic aluminum oxide. Furthermore the steric protection from the bulky $\mathrm{Ar}$ substituents at the $\mathrm{N}$ atoms of $\mathrm{L}$ allows the formation of the $\mathrm{Al}_{2}(\mu-\mathrm{O})_{2}$ unit instead of a higher condensed $\mathrm{Al}-\mathrm{O}$ product.

Compound 10 was obtained in high yield (80\%). It melts at $314-315^{\circ} \mathrm{C}$ and the isotope distributed peaks at around $\mathrm{m} / \mathrm{z} 920.4(30 \%)$ in the EI-MS spectrum are assigned to the molecular ion $\left[\mathrm{M}^{+}\right] . \mathbf{1 0}$ is soluble in hot aromatic solvents (toluene and benzene), whereas its solubility is poor at room temperature. 
Quality X-ray single crystals were grown by cooling the hot toluene solution of $\mathbf{1 0}$ to room temperature within $24 \mathrm{~h}$. The structural analysis reveals a dimer having crystallographic centro-symmetry (Figure 6). The central $\mathrm{Al}_{2}(\mu-\mathrm{O})_{2}$ core is formed in a nearly perfect square

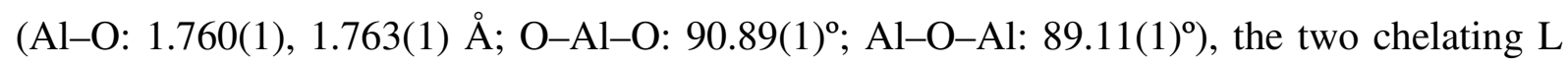
ligands at each $\mathrm{Al}$ atom are oriented with puckering $\mathrm{Al}(1) \mathrm{N}(1) \mathrm{C}(2) \mathrm{C}(3) \mathrm{C}(4) \mathrm{N}(2)$ and $\mathrm{Al}(1 \mathrm{~A}) \mathrm{N}(1 \mathrm{~A}) \mathrm{C}(2 \mathrm{~A}) \mathrm{C}(3 \mathrm{~A}) \mathrm{C}(4 \mathrm{~A}) \mathrm{N}(2 \mathrm{~A})$ rings respectively almost perpendicular $\left(89.3^{\circ}\right)$ to the square. The Al-O bond lengths are shorter than the predicted one $(1.96 \AA) .{ }^{[100]}$ This may be due to $\pi$-interaction between the oxygen $p$ orbitals and acceptor orbitals on aluminum which is discussed in a considerable number of publications. ${ }^{[101-104]}$ These bond lengths can be comp

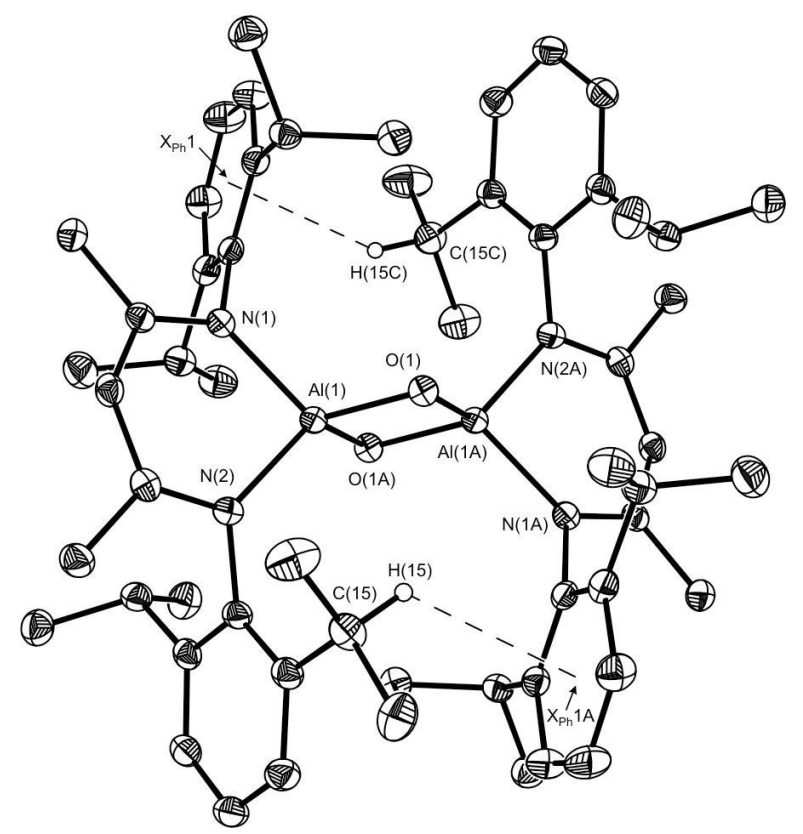

Figure 6. The molecular structure of $\mathbf{1 0}$. Selected bond lengths $\left[\AA \AA^{\circ}\right]$ and angles $\left[^{\circ}\right]: \operatorname{Al}(1)-\mathrm{O}(1)$

$$
\begin{aligned}
& \text { 1.760(1), } \mathrm{Al}(1)-\mathrm{O}(1 \mathrm{~A}) 1.763(1), \mathrm{Al}(1)-\mathrm{N}(1) 1.929(1), \mathrm{Al}(1)-\mathrm{N}(2) 1.943(1), \mathrm{Al}(1) \cdots \mathrm{Al}(1 \mathrm{~A}) \\
& \text { 2.472(1), } \mathrm{O}(1)-\mathrm{Al}(1)-\mathrm{O}(1 \mathrm{~A}) 90.86(5), \mathrm{Al}(1)-\mathrm{O}(1)-\mathrm{Al}(1 \mathrm{~A}) 89.14(5), \mathrm{N}(1)-\mathrm{Al}(1)-\mathrm{N}(2) \\
& 94.40(5), \mathrm{C}(15)-\mathrm{H}(15)(56 \%) \cdots \mathrm{X}_{\mathrm{Ph}}(1 \mathrm{~A}) 2.71, \mathrm{C}(15 \mathrm{C})-\mathrm{H}(15 \mathrm{C})(44 \%) \cdots \mathrm{X}_{\mathrm{Ph}}(1) 3.02 .
\end{aligned}
$$

-ared to those in compounds with four coordinate aluminum $\mathrm{R}_{2} \mathrm{AlOAlR}_{2}\left(\mathrm{ONMe}_{3}\right)(\mathrm{R}=$ $\left.\mathrm{CH}\left(\mathrm{SiMe}_{3}\right)_{2}, \quad 1.753(3) \AA\right)$ and $\mathrm{R}_{2}\left(\mathrm{Me}_{3} \mathrm{NO}\right) \mathrm{AlOAlR}_{2}\left(\mathrm{ONMe}_{3}\right)(1.732(2)-1.739(2) \AA)^{[105]}$ However they are longer than those in $\mathrm{L}^{*} \mathrm{AlO} \cdot \mathrm{B}\left(\mathrm{C}_{6} \mathrm{~F}_{5}\right)_{3} \quad\left(\mathrm{~L}^{*}=\right.$ $\left.\mathrm{Et}_{2} \mathrm{NCH}_{2} \mathrm{CH}_{2} \mathrm{NC}(\mathrm{Me}) \mathrm{CHC}(\mathrm{Me}) \mathrm{NCH}_{2} \mathrm{CH}_{2} \mathrm{NEt}_{2}\right) \quad(1.659(3) \quad \AA),{ }^{[106]} \quad\left[\left(\mathrm{C}_{7} \mathrm{H}_{13} \mathrm{~N}_{2}\right) \mathrm{AlCl}\right]_{2}(\mu-\mathrm{O})$ 
$(1.677(1) \AA),{ }^{[107]}$ and $\left\{t \mathrm{Bu}_{2} \mathrm{Al}\left[\mathrm{NH}(\mathrm{Me}) \mathrm{CH}_{2} \mathrm{CH}_{2} \mathrm{NMe}_{2}\right]\right\}_{2}(\mu-\mathrm{O})(1.690(7)-1.714(7) \AA),{ }^{[74]}$ as well as those in compounds $11(1.694(3)-1.698(3) \AA)$ and $\left\{[\operatorname{LAl}(\mu-\mathrm{O})]_{2}(\mu-\mathrm{O})\right\} \mathrm{AlMe}$ (1.712(2) $\AA$ ). ${ }^{[80]}$ It is noteworthy that, based on the orientation of the two L, one isopropyl group of one $\mathrm{L}$ is facing toward the aryl ring of another L, and the two methyl substituents of this $i \operatorname{Pr}$ group are arranged on the same side of the aryl plane. This arrangement is in sharp contrast to the other ones. Such structural feature is remarkable when compared with those closely related compounds 11, $\left\{[\operatorname{LAl}(\mu-\mathrm{O})]_{2}(\mu-\mathrm{O})\right\} \mathrm{AlMe},{ }^{[80]}[\mathrm{LAlCl}(\mu-\mathrm{OH})]_{2}{ }^{[108]}$ and $\mathrm{LAl}(\mu-$ $\mathrm{S})_{2} \mathrm{AlL} \cdot{ }^{[109]}$ Obviously, due to the strong electronic interaction of $\mathrm{Al}$ and $\mathrm{O}$ atoms, the $\mathrm{Al}_{2}(\mu$ $\mathrm{O})_{2}$ unit is prone to intense contacts. These contacts, however, bring the two oriented L closer together and cause a steric strain giving a stable minimum configuration and resulting in $\mathrm{C}-$ $\mathrm{H} \cdots \pi$ interactions between one isopropyl group of one $\mathrm{L}$ and the aryl ring of another $\mathrm{L}$ $\left(\mathrm{C}(15)-\mathrm{H}(15)(56 \%) \cdots \mathrm{X}_{\mathrm{Ph}}(1 \mathrm{~A}) \quad 2.71 \AA, \mathrm{C}(15 \mathrm{C})-\mathrm{H}(15 \mathrm{C}) \quad(44 \%) \cdots \mathrm{X}_{\mathrm{Ph}}(1) 3.02 \AA\right)$. Similar structural features are discussed in compounds $\mathrm{L}_{2} \mathrm{M}(\mathrm{M}=\mathrm{Mg}, \mathrm{Ca}, \mathrm{Sr}, \mathrm{Ba}) .{ }^{[110]}$ Accordingly, this indicates a considerable structural strain of $\mathbf{1 0}$, and this strain is also reflected in little longer Al-N bond lengths (1.929(1), 1.943(1) A) compared to those in 11 (1.911(3)-1.928(3) $\AA)$ and $\left\{[\mathrm{LAl}(\mu-\mathrm{O})]_{2}(\mu-\mathrm{O})\right\} \mathrm{AlMe}(1.909(2)-1.930(3) \AA)^{[80]}$ In section 2.2., we isolated compound $[\mathrm{LAlCl}(\mu-\mathrm{OH})]_{2}$ from the stepwise hydrolysis of LAlClI in the presence of $\mathrm{N}$ heterocyclic carbene (abbreviated as :C) as hydrogen halide acceptor. $[\mathrm{LAlCl}(\mu-\mathrm{OH})]_{2}$ presents a dimeric structure with $\mathrm{Al}-\mathrm{Cl}$ and $\mathrm{Al}-\mu-\mathrm{OH}$ functionalities and further treatment of this compound with two equiv of : $\mathbf{C}$ functioning as a $\mathrm{HCl}$ acceptor in an attempt to approach 10, or alternatively by the addition of $n \mathrm{BuLi}$ to eliminate $\mathrm{LiCl}$ and $n \mathrm{BuH}$ to the same target was not successful. The former resulted in no reaction and the latter led to an intractable mixture of products which was indicated by the EI mass spectrometry and proton NMR spectroscopy analysis. This may indicate the property of $\mathbf{1 0}$ that the functional changes using $[\mathrm{LAlCl}(\mu-\mathrm{OH})]_{2}$ as a precursor to approach $\mathbf{1 0}$ are energetically unfavored.

The NMR spectroscopic analysis of $\mathbf{1 0}$ clearly shows that this strained solid-state structure 
is retained in solution. In the ${ }^{1} \mathrm{H}$ NMR spectrum the isopropyl groups give rise to four separated septets and eight doublets, and two sets of aromatic signals and two singlets for the methyl group of the backbone are also observed, indicating different steric environments of two Ar groups of the LAl moiety. Moreover, one septet and one doublet of those appear at higher field (2.63 and $0.22 \mathrm{ppm}$ ) in comparison to the resonances in a series of related compounds 11, $\left\{[\mathrm{LAl}(\mu-\mathrm{O})]_{2}(\mu-\mathrm{O})\right\} \mathrm{AlMe}$, and $[\mathrm{LAlCl}(\mu-\mathrm{OH})]_{2} \quad(4.14-3.06,1.58-0.72$ ppm) ${ }^{[80,109]}$ It is clearly seen that, in view of the structure of $\mathbf{1 0}$, the corresponding methine $(\mathrm{CH})$ and methyl $\left(\mathrm{CH}_{3}\right)$ groups are shielded due to the ring current effect within the aryl groups, ${ }^{[11]}$ and this is typical for groups involved in $\mathrm{C}-\mathrm{H} \cdots \pi$ interaction (Figure 6). The ${ }^{13} \mathrm{C}\left\{{ }^{1} \mathrm{H}\right\}$ NMR data also shows the methine carbon resonance at high field (71.4 ppm).

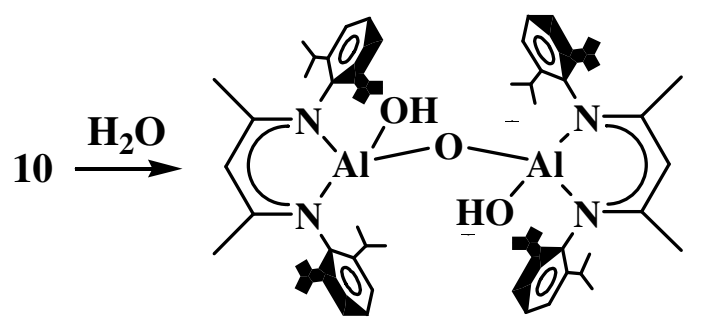

11

\section{Scheme 10}

It is interesting to note that when this sample was kept at room temperature for one month, the NMR analysis showed that the proton resonances at high field (one septet and one doublet) disappeared as well as the methine carbon resonance, and the data of the ${ }^{1} \mathrm{H}$ NMR spectrum can be identified like that of compound $\mathbf{1 1}$ including a small amount of free ligand. The transformation of $\mathbf{1 0}$ to $\mathbf{1 1}$ could be considered as a further hydrolysis of $\mathbf{1 0}$ due to the possible penetration of small amounts of moisture to the sample through the seal (Scheme 10). Nevertheless, the reaction of $\mathbf{1 0}$ with stoichiometric amounts of water was performed, and colorless crystals of 11.1.5 $n$-hexane were obtained and confirmed by X-ray structural analysis.

The reaction of $\mathrm{LAl}$ with $\mathrm{N}_{3} \mathrm{Ar}$ ' in the presence of a small amount of $\mathrm{H}_{2} \mathrm{O}$ resulted in the 
formation of a $\mathrm{C}-\mathrm{H}$ activated aluminum hydroxide $\mathbf{1 3}$, an isomer of $\mathbf{1 0}$. This reaction can be reproduced. The reaction of LAl with a large bulky azide $\mathrm{N}_{3} \mathrm{Ar}$ which has shown two types of intramolecular addition to an $\mathrm{Al}=\mathrm{N}$ multiple bond species will be detailed in section 2.8 . The respective isolation of $\mathbf{1 2}, \mathbf{1 3}$, and $\mathrm{H}_{2} \mathrm{NAr}$ ' indicates the partly hydrolysis of $\mathbf{1 2}$ to $\mathbf{1 3}$ at low temperature (Scheme 11). The Al-N bond imposed by the bulky Ar' in 12 might preferentially react with $\mathrm{H}_{2} \mathrm{O}$ to form 13, an isomer of 10. 12, 13 and $\mathrm{H}_{2} \mathrm{NAr}$ are characterized by spectral analysis, and $\mathbf{1 2}$ and $\mathbf{1 3}$ are further confirmed by X-ray measurement.

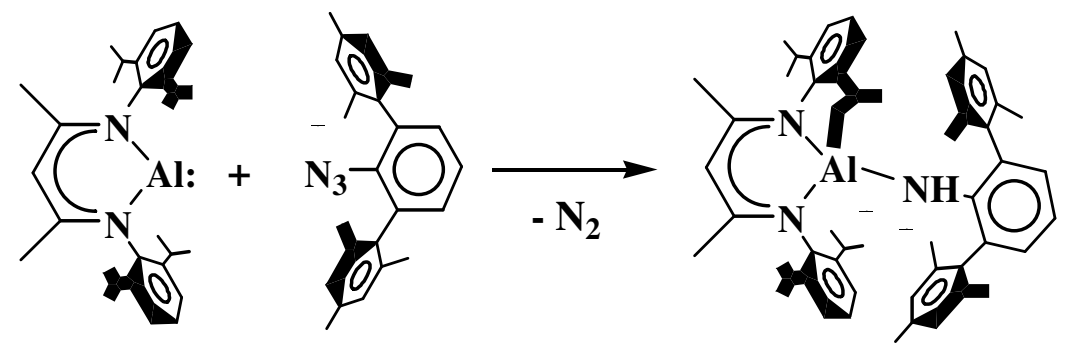

12

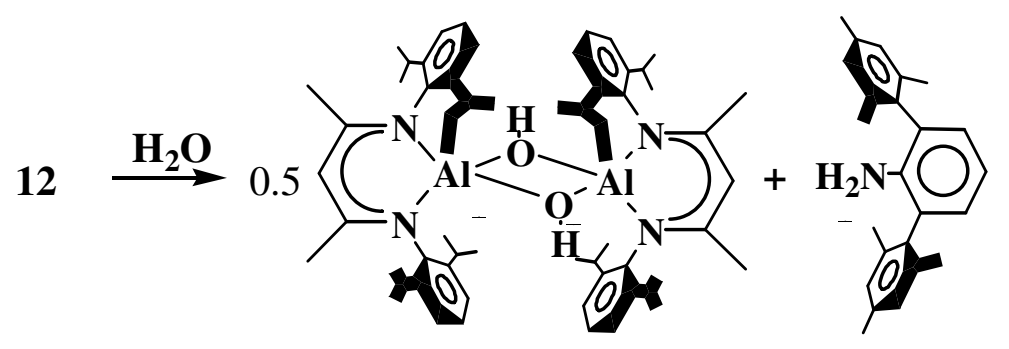

13

Scheme 11

The molecular structures of $\mathbf{1 2}$ and $\mathbf{1 3}$ are viewed in Figures 7 and 8. The structural analysis of $\mathbf{1 3}$ shows the same composition like that of $\mathbf{1 0}$ but with five coordinate $\mathrm{Al}$ and an $\mathrm{Al}_{2}(\mu-\mathrm{OH})_{2}$ non-planar core instead $(\Delta=0.1009 \AA)$. The parameters of $\mathrm{Al}-\mathrm{C}(1.988(2) \AA$ (av)) and $\mathrm{C}_{\text {activated }}-\mathrm{C}(1.552(2) \AA(\mathrm{av}))$ exhibit normal single bond distances, and those of $\mathrm{Al}_{2}(\mu-\mathrm{OH})_{2}\left(\mathrm{Al}-\mathrm{O}: 1.879(1) \AA(\mathrm{av}) ; \mathrm{O}-\mathrm{Al}-\mathrm{O}: 73.88(6)^{\mathrm{o}}(\mathrm{av}) ; \mathrm{Al}-\mathrm{O}-\mathrm{Al}: 103.40(1)^{\mathrm{o}}(\mathrm{av})\right)$ are comparable to those in $[\mathrm{LAlCl}(\mu-\mathrm{OH})]_{2}\left(\mathrm{Al}-\mathrm{O}: 1.880(1) \AA(\mathrm{av})\right.$; O-Al-O: $\left.72.46(7)^{\mathrm{o}}(\mathrm{av})\right) .^{14 \mathrm{a}}$ These data compared with those of $\mathbf{1 0}$ indicate less interference within $\mathbf{1 3}$ than in $\mathbf{1 0}$. The NMR (Al- $\mathrm{CH}_{2}: \delta-1.69(\mathrm{t}),-0.35$ (dd) ppm; Al- $\mu-\mathrm{OH}: 0.29$ (s) ppm) and IR spectral data 


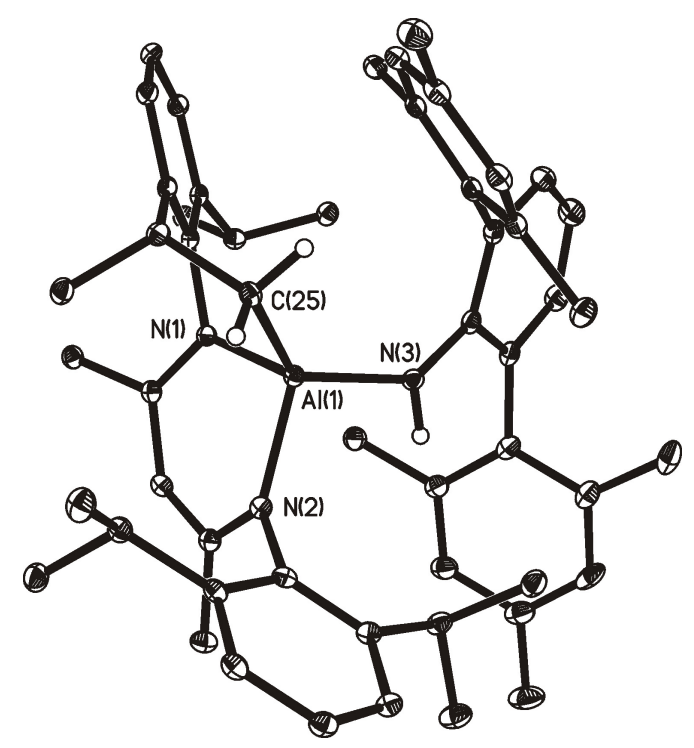

Figure 7. Molecular structure of 12. $\mathrm{H}$ atoms except for $\mathrm{Al}-\mathrm{CH}_{2}$ and $\mathrm{Al}-\mathrm{NH}$ are omitted for clarity. Selected bond lengths $(\AA)$ and angles $\left(^{\circ}\right)$ : $\mathrm{Al}(1)-\mathrm{N}(1)$ 1.930(1), $\mathrm{Al}(1)-\mathrm{N}(2)$ 1.926(2), $\mathrm{Al}(1)-\mathrm{N}(3)$ 1.840(1), $\mathrm{Al}(1)-\mathrm{C}(25)$ 1.967(2), C(25)-C(24) 1.555(2), N(1)-Al(1)-N(2) 98.12(6), N(1)-Al(1)-N(3) 113.83(6), N(2)-Al(1)-N(3) 101.98(7), N(3)-Al(1)-C(25) 124.18(7).

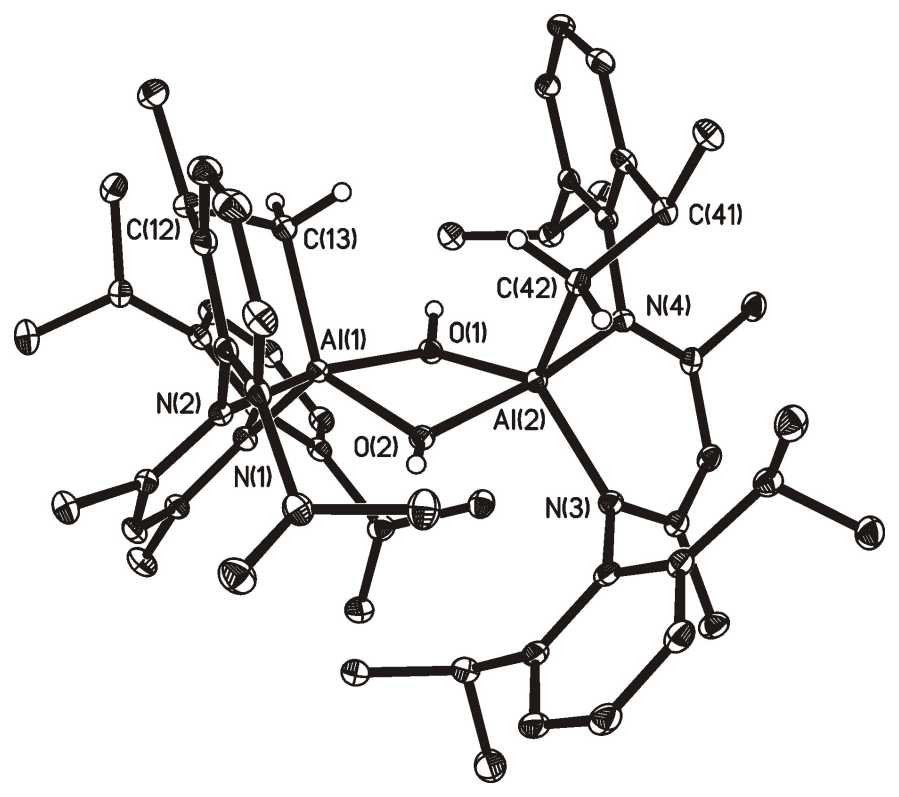

Figure 8. Molecular structure of 13. $\mathrm{H}$ atoms except for $\mathrm{Al}-\mathrm{CH}_{2}$ and $\mathrm{Al}-\mathrm{OH}$ are omitted for clarity. Selected bond lengths $(\AA)$ and angles $\left(^{\circ}\right)$ : $\mathrm{Al}(1)-\mathrm{O}(1) 1.910(1), \mathrm{Al}(1)-\mathrm{O}(2) 1.850(1)$, $\mathrm{Al}(1)-\mathrm{C}(13)$ 1.986(2), C(13)-C(12) 1.549(2), Al(2)-O(1) 1.852(1), Al(2)-O(2) 1.905(1), $\mathrm{Al}(2)-\mathrm{C}(42) 1.989(2), \mathrm{C}(42)-\mathrm{C}(41) 1.554(3), \mathrm{Al}(1) \cdots \mathrm{Al}(2) 2.950(1), \mathrm{O}(1)-\mathrm{Al}(1)-\mathrm{O}(2)$ 73.84(6), $\mathrm{Al}(1)-\mathrm{O}(2)-\mathrm{Al}(2)$ 103.54(6), $\mathrm{O}(2)-\mathrm{Al}(2)-\mathrm{O}(1)$ 73.92(6), $\mathrm{Al}(2)-\mathrm{O}(1)-\mathrm{Al}(1)$ 
(Al- $\mu-\mathrm{OH}: v 3400(\mathrm{br}) \mathrm{cm}^{-1}$ ) also confirm the functionalities of $\mathbf{1 3}$.

Although 10 does not contain three coordinate Al centers which are proposed to have strong Lewis acidity and are vital for catalytic activity, the notably structural character of $\mathbf{1 0}$ prompted us to test its cocatalytic property for the dimethylzirconocene polymerization of ethylene in toluene solution at either 25 or $80{ }^{\circ} \mathrm{C}$. However, no activity was observed. Moreover, no reaction occurred between $\mathbf{1 0}$ and $\mathrm{Cp}_{2} \mathrm{ZrMe}_{2}$.

In conclusion, the oxidative reaction of aluminum(I) monomer LAl with molecular oxygen has been shown. This reaction type exhibits the $\mathrm{O}_{2}$ oxidation of a central metal to yield alumoxane $[\mathrm{LAlO}]_{2}(\mathbf{1 0})$, the hitherto unknown species, and represents a new synthetic approach to alumoxane. Compound $\mathbf{1 0}$ further reacts with one molecule of water to form alumoxane hydroxide $[\mathrm{LAl}(\mathrm{OH})]_{2}(\mu-\mathrm{O})(\mathbf{1 1})$. Although 11 has been known and prepared by another route ${ }^{[80]}$ this reaction may proceed through the coordination of $\mathrm{H}_{2} \mathrm{O}$ to the aluminum center. A further proton transfer from the coordinated $\mathrm{H}_{2} \mathrm{O}$ molecule results in the ring opening of the $\mathrm{Al}_{2}(\mu-\mathrm{O})_{2}$ unit under the formation of terminal $\mathrm{Al}-\mathrm{OH}$ functionalities, this implies a strain releasing process from $\mathbf{1 0}$ to 11. A further application of proton transfer using $\mathrm{EH}_{\mathrm{n}}(\mathrm{E}=\mathrm{S}, \mathrm{Se}, \mathrm{Te}, \mathrm{n}=2 ; \mathrm{E}=\mathrm{N}, \mathrm{P}, \mathrm{As}, \mathrm{Sb}, \mathrm{n}=3)$ molecules and $\mathbf{1 0}$ to yield the unknown $\mathrm{Al}-\mathrm{EH}_{\mathrm{n}-1}$ species is currently under investigation in our group. 


\subsection{Reactions of Aluminum(I) Monomer LAI with Imidazol-2-ylidene and}

\section{Diphenyldiazomethane: A Hydrogen Transfer of the L Ligand to the Aluminum}

\section{Center and a Formation of a Diiminyl Aluminum Compound $\mathrm{LAl}\left(\mathrm{N}=\mathrm{CPh}_{2}\right)_{2}$}

Abstract: The solid-state reaction of LAl and imidazol-2-ylidene at elevated temperature (120 $\left.{ }^{\circ} \mathrm{C}\right)$ yielded the aluminum monohydride $N$-heterocyclic carbene adduct $\left[\mathrm{HC}\left\{\mathrm{C}\left(\mathrm{CH}_{2}\right) \mathrm{NAr}\right\}(\mathrm{CMeNAr})\right] \mathrm{AlH}\left[\mathrm{CN}(\mathrm{R}) \mathrm{C}_{2} \mathrm{Me}_{2} \mathrm{~N}(\mathrm{R})\right](\mathrm{R}=\mathrm{iPr}(\mathbf{1 4}), \mathrm{Me}(\mathbf{1 5}))$. Compounds 14 and 15 have been characterized by spectroscopic (IR, ${ }^{1} H$, and $\left.{ }^{13} \mathrm{C} N M R\right)$, mass spectrometric, and elemental analyses, and $\mathbf{1 4}$ was further characterized by X-ray structural analysis. These experimental data indicate that the $\mathrm{Al}-\mathrm{H}$ bond is formed by hydrogen migration from one of the methyl groups of the $\beta$-diketiminato ligand backbone. The reaction of LAl with equivalent amounts of diphenyldiazomethane afforded the diiminyl aluminum compound $\mathrm{LAl}\left(\mathrm{N}=\mathrm{CP} \mathrm{h}_{2}\right)_{2}$ (16), while with an excess diphenyldiazomethane resulted in the formation of $\mathrm{Ph}_{2} \mathrm{C}=\mathrm{N}-$ $\mathrm{N}=\mathrm{CP} h_{2}$. This suggests that the $\mathrm{Ph}_{2} \mathrm{C}=\mathrm{N}-\mathrm{N}=\mathrm{CP} h_{2}$ is initially generated and then further reacts under oxidative addition to yield 16.

Monovalent Group 13 species are of considerable interest not only due to their syntheses, structures, and theoretical investigations, ${ }^{[112-113]}$ but more due to their reactivity. ${ }^{[114]}$ In the last decade, a variety of new reactions has been intensively explored generating the tetrameric aluminum(I) compounds. ${ }^{[115-120]}$ Compound $\left(\mathrm{Cp}^{*} \mathrm{Al}\right)_{4}$ was reported to have a remarkable tendency to dissociate in solution and give a monomeric fragment in the gas phase. ${ }^{[121-122]}$ The reactions involving such species have also been investigated to some extent and a number of novel compounds were isolated and structurally characterized. ${ }^{[123-127]}$ Recently, we have prepared the first monomeric aluminum(I) $\mathrm{LAl}\left(\mathrm{L}=\mathrm{HC}[(\mathrm{CMe})(\mathrm{NAr})]_{2}, \mathrm{Ar}=2,6-i \mathrm{Pr}_{2} \mathrm{C}_{6} \mathrm{H}_{3}\right)$ stable at room temperature. ${ }^{[95]} \mathrm{Ab}$ initio calculations show that this monomer possesses a nonbonded electron pair at the central two coordinated $\mathrm{Al}$ atom and is isoelectronic with a singlet carbene. Subsequent examination of LAl with organic azides at low temperature or with $\mathrm{P}_{4}$ at room temperature indicates its reactivity, leading to the formation of a five- 
membered $\mathrm{AlN}_{4}$ heterocycle $\mathrm{LAl}\left[\left(\mathrm{NSiMe}_{3}\right)_{2} \mathrm{~N}_{2}\right]$, a monomeric aluminum imide $\mathrm{LAl}(\mathrm{N}-2,6-$ Trip $\left.{ }_{2} \mathrm{C}_{6} \mathrm{H}_{3}\right)\left(\right.$ Trip $\left.=2,4,6-i \mathrm{Pr}_{3} \mathrm{C}_{6} \mathrm{H}_{2}\right)$, and a sandwich compound $(\mathrm{LAl})_{2} \mathrm{P}_{4}$ containing a $\mathrm{P}_{4}^{4-}$ unit. $^{[129-131]}$ These results are markedly different from those in which $\left(\mathrm{Cp}^{*} \mathrm{Al}\right)_{4}$ is used in related reactions. Obviously, the steric and electronic stabilization from the bulky $\beta$ diketiminato ligand enables its monomeric nature and therefore its unique chemical behaviour, and allows further investigation of its reactivity.

Imidazol-2-ylidene is a stable neutral $N$-heterocyclic carbene which has been prepared in recent years. ${ }^{[132]}$ The diphenyldiazomethane can be used as an effective precursor for the generation of transient $: \mathrm{CPh}_{2} \cdot{ }^{[133-135]}$ The reaction of imidazol-2-ylidene with monovalent Group 13 compounds is only reported for $\mathrm{InBr}$, in which a disproportionation is observed. ${ }^{[136]}$ More recently, a handful of reactions involving imidazol-2-ylidene with trivalent Group 13 species have been investigated, and herein the $N$-heterocyclic carbene functions as a Lewis base. ${ }^{[137-141]}$ Corresponding reactions of diphenyldiazomethane with Group 13 element(I) species have not been described so far. We now report on the reaction of LAl with imidazol2-ylidene and diphenyldiazomethane, respectively. The formation of the aluminum monohydride $N$-heterocyclic carbene adduct of composition $\left[\mathrm{HC}\left\{\mathrm{C}\left(\mathrm{CH}_{2}\right) \mathrm{NAr}\right\}(\mathrm{CMeNAr})\right] \mathrm{AlH}\left[\mathrm{CN}(\mathrm{R}) \mathrm{C}_{2} \mathrm{Me}_{2} \mathrm{~N}(\mathrm{R})\right](\mathrm{R}=i \operatorname{Pr}(\mathbf{1 4}), \mathrm{Me}(\mathbf{1 5}))$ indicates a hydrogen transfer from the L ligand to the aluminum center. The formation of a diiminyl aluminum compound $\mathrm{LAl}\left(\mathrm{N}=\mathrm{CPh}_{2}\right)_{2}$ (16) might proceed through the initial generation of $\mathrm{Ph}_{2} \mathrm{C}=\mathrm{N}-\mathrm{N}=\mathrm{CPh}_{2}$ followed by its oxidative addition to $\mathrm{LAl}$.

The initial reaction of $\mathrm{LAl}$ with 1,3-diisopropyl-4,5-dimethylimidazol-2-ylidene was conducted in toluene within the temperature range from 25 to $80^{\circ} \mathrm{C}$. However due to the low solubility of the $N$-heterocyclic carbene, this reaction was not successful. Therefore both starting materials were treated in the solid-state at $120{ }^{\circ} \mathrm{C}$ for $5 \mathrm{~h}$. The softening of 1,3diisopropyl-4,5-dimethylimidazol-2-ylidene and a subsequent color change of LAl from red black to light yellow were observed. An extraction of the product with hot toluene and 
keeping the eluate at room temperature afforded crystalline compound $\left[\mathrm{HC}\left\{\mathrm{C}\left(\mathrm{CH}_{2}\right) \mathrm{NAr}\right\}(\mathrm{CMeNAr})\right] \mathrm{AlH}\left[\mathrm{CN}(i \mathrm{Pr}) \mathrm{C}_{2} \mathrm{Me}_{2} \mathrm{~N}(i \mathrm{Pr})\right](\mathbf{1 4}$, Scheme 12).

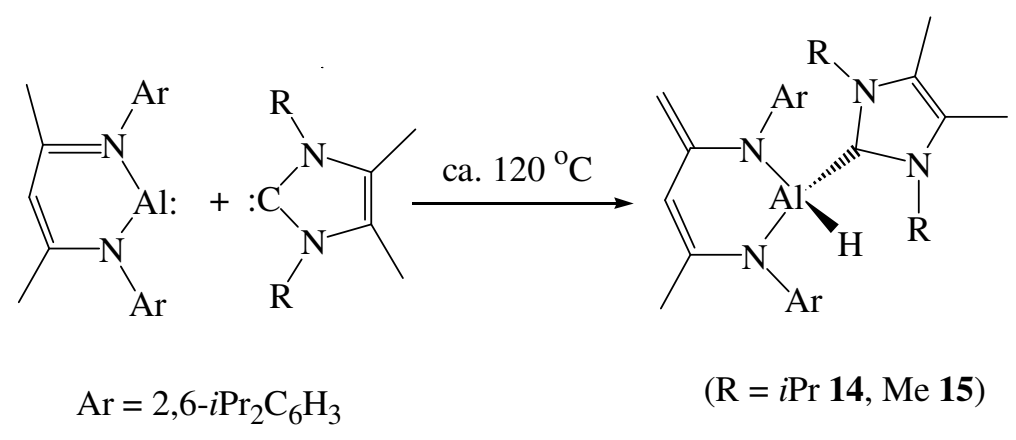

Scheme 12

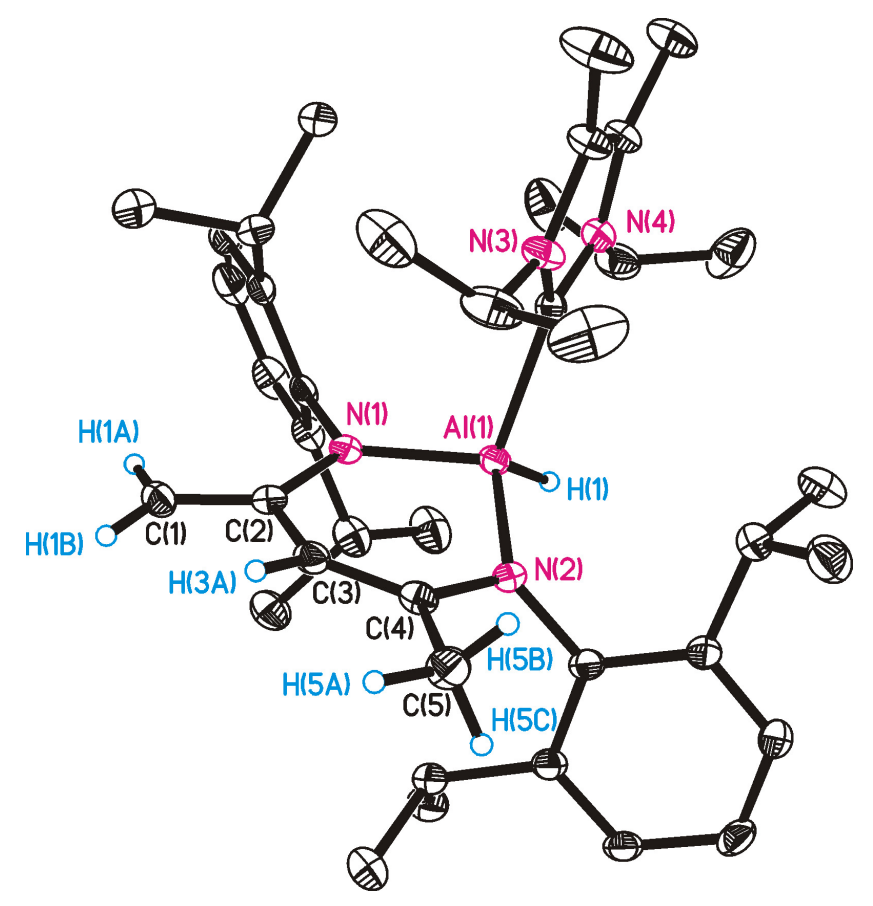

Figure 9. Molecular structure of 14. H atoms in Ar and :C groups are omitted for clarity.

Selected bond lengths $(\AA)$ and angles $\left(^{\circ}\right)$ : $\mathrm{Al}(1)-\mathrm{N}(1)$ 1.853(2), $\mathrm{Al}(1)-\mathrm{N}(2) 1.844(3), \mathrm{Al}(1)-$

$$
\begin{gathered}
\mathrm{C}(30) 2.088(3), \mathrm{Al}(1)-\mathrm{H}(1) 1.40, \mathrm{~N}(1)-\mathrm{C}(2) 1.411(3), \mathrm{N}(2)-\mathrm{C}(4) 1.413(3), \mathrm{C}(1)-\mathrm{C}(2) \\
1.363(4), \mathrm{C}(2)-\mathrm{C}(3) 1.458(4), \mathrm{C}(3)-\mathrm{C}(4) 1.351(4), \mathrm{C}(4)-\mathrm{C}(5) 1.507(4), \mathrm{N}(1)-\mathrm{Al}(1)-\mathrm{N}(2) \\
102.05(6), \mathrm{C}(30)-\mathrm{Al}(1)-\mathrm{H}(1) 106.4 .
\end{gathered}
$$

Compound $\mathbf{1 4}$ is colorless and soluble in hot toluene and benzene while sparingly soluble in $n$-hexane and pentane. It has been characterized by spectroscopic and elemental analyses. The mass spectrum exhibits the molecular ion of $14\left\{\mathrm{~m} / \mathrm{z}(\%)=624(5)\left[M^{+}\right], 609(40)\left[M^{+}-\right.\right.$ 
Me], $\left.581(100)\left[M^{+}-i \operatorname{Pr}\right]\right\}$. The ${ }^{1} \mathrm{H}$ and ${ }^{13} \mathrm{C}$ NMR spectra recorded in $\mathrm{C}_{6} \mathrm{D}_{6}$ are consistent with a pseudo tetrahedral geometry and $C s$ symmetry about aluminum, which give rise to six isopropyl $\mathrm{CH}$ resonances and twelve diastereotopic splitted isopropyl $\mathrm{CH}_{3}$ resonances due to the chiral environment of the $\mathrm{Al}$ center. It is noted that the proton resonance of $\beta-\mathrm{CH}_{3}(\delta 1.72$ ppm) at the L ligand backbone is indicative for $3 \mathrm{H}$, while two other singlets are observed downfield $(\delta 3.98$ and $3.30 \mathrm{ppm})$ for $(1+1) \mathrm{H}$. The former corresponds to the normal terminal $\mathrm{CH}_{3}-\mathrm{C}$ group, and the latter is assigned to the terminal $\mathrm{CH}_{2}=\mathrm{C}$ group which gives rise to two non-equivalent protons due to the restricted rotation about the $\mathrm{C}=\mathrm{C}$ double bond. One broad proton resonance centered at $4.80 \mathrm{ppm}$ is characteristic for aluminum hydrides, ${ }^{[29]}$ and the IR spectrum exhibits a single band at $1809 \mathrm{~cm}^{-1}$ for $\mathrm{Al}-\mathrm{H}$ absorption. ${ }^{[142]}$

Complex 14 has also been characterized by X-ray structural analysis. The quality of the crystals by several recrystallizations from different solvents gave no improvement in the refinement of the structure. Nonetheless, the structural solution of $\mathbf{1 4}$ offers important structural informations which are in agreement with its spectral analysis. The molecular structure of $\mathbf{1 4}$ is shown in Figure 9 with selected bond lengths and angles. Compound $\mathbf{1 4}$ is monomeric and the central $\mathrm{Al}$ atom adopts a distorted tetrahedral geometry. The $\mathrm{Al}-\mathrm{N}$ bond lengths $(1.844(3), 1.853(2) \AA)$ appear the shortest compared to those $\mathrm{Al}-\mathrm{N}_{\beta \text {-diketiminato }}$ $(1.875(4)-1.957(2) \AA),{ }^{[21,75,80,95]}$ and are closer to those found in diamide aluminum monohydride $\left[\mathrm{ArN}\left(\mathrm{CH}_{2}\right)_{3} \mathrm{NAr}\right] \mathrm{AlH}\left(\mathrm{NMe}_{3}\right) \quad\left(1.820(1), 1.828(1) \AA{ }^{[142]}\right.$ In the ligand backbone, the terminal $\mathrm{C}-\mathrm{C}$ bond distances $(\mathrm{C}(4)-\mathrm{C}(5), 1.507(4) \AA$; $C(1)-C(2), 1.363(4) \AA)$ are indicative for a single and double bond character, respectively, as well as the others within the backbone $(\mathrm{C}(2)-\mathrm{C}(3), 1.458(4) \AA ; \mathrm{C}(3)-\mathrm{C}(4), 1.351(4) \AA)$. The adjacent N-C bonds (1.411(3), 1.413(3) ̊) are located between N-C double and single bonds.

Obviously, the Al-H hydrogen comes from one of the terminal methyl groups of the $\mathrm{L}$ ligand. However, such hydrogen transfer via proton, hydrogen radical, or hydride is not clear.

The reaction of the LAl with less bulky $N$-substituted 1,3,4,5-tetramethylimidazol-2- 
ylidene was also performed in a similar manner (method A) like the preparation of $\mathbf{1 4}$ to investigate the steric bulk on the reaction product. As a result, $\left[\mathrm{HC}\left\{\mathrm{C}\left(\mathrm{CH}_{2}\right) \mathrm{NAr}\right\}(\mathrm{CMeNAr})\right] \mathrm{AlH}\left[\mathrm{CN}(\mathrm{Me}) \mathrm{C}_{2} \mathrm{Me}_{2} \mathrm{~N}(\mathrm{Me})\right]$ (15) was obtained in a relatively low yield. All the spectroscopic (IR, EI mass, ${ }^{1} \mathrm{H}$ and ${ }^{13} \mathrm{C}$ NMR) data confirm the analogue structural arrangement like that of $\mathbf{1 4}$ with 1,3,4,5-tetramethylimidazol-2-ylidene as a ligand.

In the majority of organic and organometallic reactions, diphenyldiazomethane is used as an effective precursor for the generation of transient $: \mathrm{CPh}_{2}$ carbene. ${ }^{[133-135]}$ Therefore, it was selected as another electron-rich species for the reaction with LAl. However, treatment of LAl with 2 equivalents of $\mathrm{N}_{2} \mathrm{CPh}_{2}$ under heating unexpectedly afforded $\mathrm{LAl}\left(\mathrm{N}=\mathrm{CPh}_{2}\right)_{2}$ (16, Scheme 13), the first example of a diiminyl aluminum compound. When LAl was treated with an excess of $\mathrm{N}_{2} \mathrm{CPh}_{2}$ under the same condition $\mathrm{Ph}_{2} \mathrm{C}=\mathrm{N}-\mathrm{N}=\mathrm{CPh}_{2}$ was isolated. The azine $\mathrm{Ph}_{2} \mathrm{C}=\mathrm{N}-\mathrm{N}=\mathrm{CPh}_{2}$ was obtained as colorless crystals with a melting point of $174{ }^{\circ} \mathrm{C}$ and the spectroscopic data (EI mass, IR, ${ }^{1} \mathrm{H}$ and ${ }^{13} \mathrm{C}$ NMR) and elemental analysis confirmed the composition. It is well-known that many salts and complexes of $\mathrm{Cu}(\mathrm{I})$ and $\mathrm{Cu}(\mathrm{II})$ are used as catalysts for the decomposition of diphenyldiazomethane. The reaction of LAl and diphenyldiazomethane to give $\mathrm{Ph}_{2} \mathrm{C}=\mathrm{N}-\mathrm{N}=\mathrm{CPh}_{2}$ may indicate that the LAl plays more likely a catalytic role ${ }^{[143-144]}$ Therefore we assume that the formation of $\mathbf{1 6}$ might proceed via the initial generation of $\mathrm{Ph}_{2} \mathrm{C}=\mathrm{N}-\mathrm{N}=\mathrm{CPh}_{2}$ followed by its oxidative addition to LAl. In order to testify the possibility of the latter step, a toluene solution of LAl with equivalent amounts of $\mathrm{Ph}_{2} \mathrm{C}=\mathrm{N}-\mathrm{N}=\mathrm{CPh}_{2}$ was conducted under reflux and complex $\mathbf{1 6}$ was formed as expected in an almost quantitative yield. A reaction procedure is described here. A mixture of equivalent amounts of $\mathrm{LAl}$ and $\mathrm{Ph}_{2} \mathrm{C}=\mathrm{N}-\mathrm{N}=\mathrm{CPh}_{2}$ in toluene $(20 \mathrm{~mL})$ was allowed slowly to heat to reflux and kept for $3 \mathrm{~h}$. After cooling to room temperature, the solution was dried in vacuum and the residue was washed with $n$-hexane $(5 \mathrm{~mL})$ to give an almost quantitative orangeyellow crystalline solid (yield, $>90 \%$ ). The melting point and the spectroscopic data (EI mass and IR) are essentially the same as those of $\mathbf{1 6 .}$ 


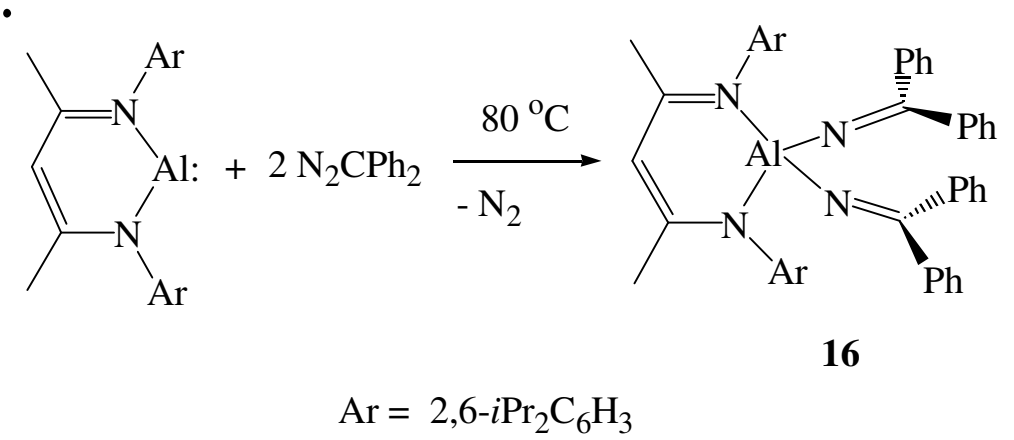

\section{Scheme 13}

Complex 16 is an orange-yellow crystalline solid and thermally stable as indicated by its high melting point $\left(344-346^{\circ} \mathrm{C}\right)$. The most intense ion in the EI mass spectrum appears at $\mathrm{m} / \mathrm{z}$ $624\left[M^{+}-\mathrm{NCPh}_{2}\right]$, and the peak at $m / z \quad 805(20 \%)$ is assigned to the molecular ion $\left[M^{+}\right]$.

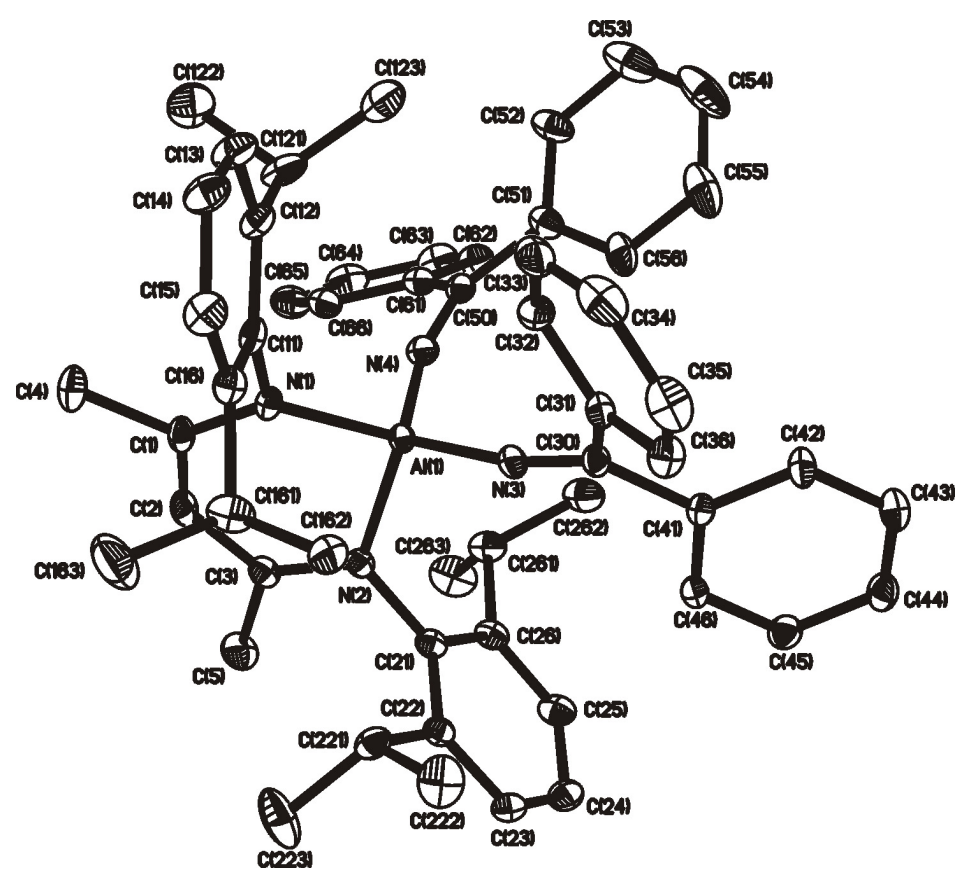

Figure 10. Molecular structure of 16. $\mathrm{H}$ atoms are omitted for clarity. Selected bond lengths $(\AA)$ and angles $\left({ }^{\circ}\right)$ : $\mathrm{Al}(1)-\mathrm{N}(1) 1.901(4), \mathrm{Al}(1)-\mathrm{N}(2)$ 1.899(4), $\mathrm{Al}(1)-\mathrm{N}(3)$ 1.774(4), $\mathrm{Al}(1)-$

$$
\begin{aligned}
& \mathrm{N}(4) 1.785(4), \mathrm{N}(3)-\mathrm{C}(30) 1.249(6), \mathrm{N}(4)-\mathrm{C}(50) \text { 1.269(6), } \mathrm{N}(1)-\mathrm{Al}(1)-\mathrm{N}(2) 97.23(18), \\
& \mathrm{N}(3)-\mathrm{Al}(1)-\mathrm{N}(4) 116.1(2), \mathrm{C}(30)-\mathrm{N}(3)-\mathrm{Al}(1) 169.4(4), \mathrm{C}(50)-\mathrm{N}(4)-\mathrm{Al}(1) 163.4(5)
\end{aligned}
$$

X-ray quality single crystals of $\mathbf{1 6}$ were grown in 1:1 solvent mixture ( $n$-hexane, ether) at $4{ }^{\circ} \mathrm{C}$ for $2 \mathrm{~d}$. The structural analysis unambiguously ascertains the composition of $\mathbf{1 6}$. The molecular structure is viewed in Figure 8 with selected bond lengths and angles. The central 
$\mathrm{Al}$ atom is bound to two $\beta$-diketiminato nitrogen and two iminyl nitrogen atoms. The $\mathrm{AlN}_{4}$ core exhibits a distorted tetrahedral geometry with trans $\mathrm{N}-\mathrm{Al}-\mathrm{N}$ angles ranging from $97.23(18)^{\circ}$ to $117.6(2)^{\circ}$. The $\mathrm{Al}-\mathrm{N}_{\beta \text {-diketiminato }}$ bond lengths $(1.899(4), 1.901(4) \AA)$ are falling in the expected range $(1.875(4)-1.957(2) \AA)$. However, the $\mathrm{Al}-\mathrm{N}_{\text {iminyl }}$ distances $(1.774(4)$, $1.785(4) \AA$ ) are the shortest among those found in four coordinated Al-N complexes. ${ }^{[145]}$ Comparable Al-N bond lengths are only observed in three coordinated Trip ${ }_{2} \mathrm{AlN}(\mathrm{H}) \mathrm{Dipp}$ $(1.784(3) \AA),{ }^{[146]}\left[\mathrm{MeAlNDipp}_{3}(1.782(4) \AA)^{[147]}\right.$ and $\mathrm{Al}\left[\mathrm{N}\left(\mathrm{SiMe}_{3}\right)_{2}\right]_{3} \quad(1.78(2) \AA)^{[148]}$ Surprisingly, the N-C distances of the iminyl group (1.249(6), 1.269(6) $\AA$ ) are shorter compared to that of a carbon-nitrogen double bond. ${ }^{[149]}$ The short $\mathrm{Al}-\mathrm{N}_{\text {iminyl }}$ bond can be considered to be highly ionic, and the shortening of the $\mathrm{N}=\mathrm{C}$ bond may be due to a charge delocalization over the phenyl groups. The $\mathrm{Al}(1)-\mathrm{N}(4)-\mathrm{C}(50)\left(163.4(5)^{\circ}\right)$ and $\mathrm{Al}(1)-\mathrm{N}(3)-$ $\mathrm{C}(30)\left(169.4(4)^{\circ}\right)$ angles show the less bent arrangement of the $\mathrm{Al}-\mathrm{N}=\mathrm{C}$ group. The observation of two sets of resonances for the iminyl phenyl rings in the ${ }^{1} \mathrm{H}$ and ${ }^{13} \mathrm{C} \mathrm{NMR}$ spectra suggests a restricted rotation of phenyl rings around the $\mathrm{N}=\mathrm{C}$ bond. This is confirmed by the high temperature proton NMR spectral analysis $\left(40,60\right.$, and $\left.80{ }^{\circ} \mathrm{C}\right)$, where two corresponding sets of such resonances are always observed.

To sum up, the reaction of the aluminum(I) monomer LAl with imidazol-2-ylidene and diphenyldiazomethane, respectively, afforded the new compounds $\left[\mathrm{HC}\left\{\mathrm{C}\left(\mathrm{CH}_{2}\right) \mathrm{NAr}\right\}(\mathrm{CMeNAr})\right] \mathrm{AlH}\left[\mathrm{CN}(\mathrm{R}) \mathrm{C}_{2} \mathrm{Me}_{2} \mathrm{~N}(\mathrm{R})\right] \quad(\mathrm{R}=i \operatorname{Pr} \quad(\mathbf{1 4}), \quad \mathrm{Me} \quad(\mathbf{1 5}))$ and $\mathrm{LAl}\left(\mathrm{N}=\mathrm{CPh}_{2}\right)_{2}(\mathbf{1 6})$. This further shows the unique reaction behaviour of LAl, and exhibits its properties of a carbene analogue. Inspired by these results, we are now exploring the reaction of LAl with metal carbonyl complexes to compare the electronic equivalence of LAl with CO. 


\subsection{A Rearrangement of Azobenzene by}

\section{Interaction with an Aluminum(I) Monomer LAI}

Abstract: Reaction of LAl or $\mathrm{LAl}\left[\eta^{2}-\mathrm{C}_{2}\left(\mathrm{SiMe}_{3}\right)_{2}\right]\left(\mathrm{L}=\mathrm{HC}[(\mathrm{CMe})(\mathrm{NAr})]_{2}, \mathrm{Ar}=2,6-\mathrm{PPr}_{2} \mathrm{C}_{6} \mathrm{H}_{3}\right)$ with azobenzene both afforded a five-membered ring compound $L A l\left[N(H)-o-C_{6} H_{4} N(P h)\right]$ (17). In the formation of 17 a three-membered intermediate $L A l\left(\eta^{2}-N_{2} P h_{2}\right)(A)$ is suggested by $[1+2]$ cycloaddition reaction, $\boldsymbol{A}$ is not stable and further rearranges to 17 . The DFT calculations on comparable compounds with modified $L^{\prime}\left(L^{\prime}=H C[(C M e)(N P h)]_{2}\right)$ show that the complexation energy of the reaction of $L^{\prime} A l$ with azobenzene to $L^{\prime} A l\left(\eta^{2}-N_{2} P h_{2}\right)$ is ca. -39 $\mathrm{kcal} / \mathrm{mol}$, and the best estimate of the energy difference between $L$ 'Al $\left(\eta^{2}-\mathrm{N}_{2} P h_{2}\right)$ and $L^{\prime} A l\left[N(H)-o-C_{6} H_{4} N(P h)\right]$ is $-76 \mathrm{kcal} / \mathrm{mol}$.

The reactions of Group 13 metal(I) tetramers $(\mathrm{RM})_{4}(\mathrm{R}=$ organic group, $\mathrm{M}=\mathrm{Al}, \mathrm{Ga}, \mathrm{In})$ with unsaturated molecules $\left(\mathrm{H}_{2} \mathrm{C}=\mathrm{C}(\mathrm{Me})-\mathrm{C}(\mathrm{Me})=\mathrm{CH}_{2}, \quad \mathrm{PhC}(\mathrm{O})-\mathrm{C}(\mathrm{O}) \mathrm{Ph}, \quad \mathrm{RN}=\mathrm{C}(\mathrm{H})-\right.$ $\mathrm{C}(\mathrm{H})=\mathrm{NR}, \mathrm{R}=\mathrm{Me}, i \mathrm{Pr})^{[150-153]}$ evidence the trapping of the corresponding monomer RM, and meanwhile present an interesting oxidative addition of compounds with unsaturated bonds to low-valent metal centers. ${ }^{[114]}$ This leads to heterocyclic compounds containing novel heavier main group elements which have the potential application in pharmaceutical, agrochemical, and material science. ${ }^{[154]}$ We have recently prepared the aluminum(I) monomer LAl $(\mathrm{L}=$ $\left.\mathrm{HC}[(\mathrm{CMe})(\mathrm{NAr})]_{2}, \mathrm{Ar}=2,6-i \mathrm{Pr}_{2} \mathrm{C}_{6} \mathrm{H}_{3}\right)$ which has a singlet carbene character. ${ }^{[95]}$ The reductive coupling reaction of $\mathrm{LAlI}_{2}$ with potassium in the presence of alkynes has shown a [1 + 2] cycloaddition to yield aluminacyclopropene $\mathrm{LAl}\left[\eta^{2}-\mathrm{C}_{2}(\mathrm{R}) \mathrm{R}^{\prime}\right]\left(\mathrm{R}=\mathrm{R}^{\prime}=\mathrm{SiMe}_{3}, \mathrm{Ph} ; \mathrm{R}=\right.$ $\left.\mathrm{Ph}, \quad \mathrm{R}^{\prime}=\mathrm{SiMe}_{3}\right){ }^{[155]} \mathrm{A}$ direct coupling reaction between $\mathrm{LAl}$ and alkyne $\left.\left(\mathrm{Me}_{3} \mathrm{SiC} \equiv \mathrm{CC} \equiv \mathrm{CSiMe}\right)_{3}\right)$ is subsequently realized to form $\mathrm{LAl}\left[\eta^{2}-\mathrm{C}_{2}\left(\mathrm{SiMe}_{3}\right)(\mathrm{C} \equiv \mathrm{CSiMe})\right]$. In this context we are interested in the interaction of the $\mathrm{Al}(\mathrm{I})$ center with compounds containing a $\mathrm{N}=\mathrm{N}$ double bond. The reaction of $\mathrm{LAl}$ or $\mathrm{LAl}\left[\eta^{2}-\mathrm{C}_{2}\left(\mathrm{SiMe}_{3}\right)_{2}\right]$ with azobenzene both unexpectedly resulted in the formation of a five-membered ring complex $\operatorname{LAl}\left[\mathrm{N}(\mathrm{H})-o_{-}\right.$ $\mathrm{C}_{6} \mathrm{H}_{4} \mathrm{~N}(\mathrm{Ph})$ ] (17). Compound 17 contains a $\mathrm{N}(\mathrm{H})-o-\mathrm{C}_{6} \mathrm{H}_{4} \mathrm{~N}(\mathrm{Ph})$ moiety which presents an 
isomerized azobenzene. Obviously, a rearrangement of azobenzene is occurring by interacting with LAl.

Upon stirring a toluene solution of $\mathrm{LAl}$ and azobenzene at elevated temperature $\left(80^{\circ} \mathrm{C}\right)$ for $5 \mathrm{~h}$, the red color changed to orange. Partial removal of the solvent in vacuum and addition of $n$-hexane led to the crystallization of $\mathbf{1 7}$ at $4{ }^{\circ} \mathrm{C}$ as orange crystals in good yield. An alternative route to $\mathbf{1 7}$ was investigated by the reaction of $\mathrm{LAl}\left[\eta^{2}-\mathrm{C}_{2}\left(\mathrm{SiMe}_{3}\right)_{2}\right]$ with azobenzene in the temperature range from $-50{ }^{\circ} \mathrm{C}$ to room temperature. The result indicated that $\mathrm{LAl}\left[\eta^{2}-\mathrm{C}_{2}\left(\mathrm{SiMe}_{3}\right)_{2}\right]$ could be used as a good precursor for LAl.

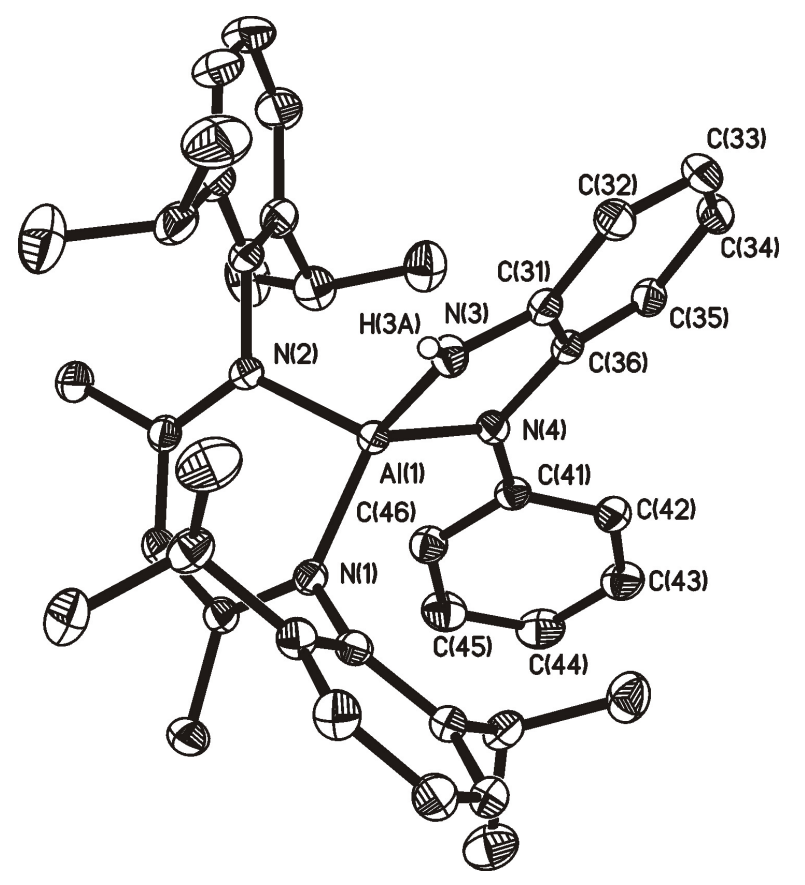

Figure 11. Molecular structure of compound 17. The hydrogen atoms of the $\mathrm{C}-\mathrm{H}$ bonds are omitted for clarity. Selected bond lengths ( $⿱$ ) and angles (deg): $\mathrm{Al}(1)-\mathrm{N}(1)$ 1.862(1), $\mathrm{Al}(1)-$ $\mathrm{N}(2) 1.893(1), \mathrm{Al}(1)-\mathrm{N}(3)$ 1.807(2), Al(1)-N(4) 1.847(1), N(3)-C(31) 1.386(2), C(31)-C(36) 1.429(2), C(36)-N(4) 1.420(2), N(1)-Al(1)-N(2) 97.68(6), N(3)-Al(1)-N(4) 90.39(6), Al(1)$\mathrm{N}(3)-\mathrm{C}(31)$ 109.86(10), N(3)-C(31)-C(36) 115.57(14), C(31)-C(36)-N(4) 113.40(10),

$$
\mathrm{C}(36)-\mathrm{N}(4)-\mathrm{Al}(4) 108.44(10) \text {. }
$$

Compound 17 is thermally stable, as indicated by its high melting point $\left(260-261^{\circ} \mathrm{C}\right)$ and its most intense molecular ion peak (m/z (\%): $626\left(100,\left[M^{+}\right]\right)$recorded in EI-mass spectrum. 
17 has been fully characterized by spectroscopic, analytical and X-ray single crystal measurements.

The molecular structure of $\mathbf{1 7}$ is viewed in Figure 11 with selected bond lengths and angles. The central $\mathrm{Al}$ atom is involved as part of two fused five- $\left(\mathrm{AlN}_{2} \mathrm{C}_{2}\right)$ and six-membered $\left(\mathrm{AlN}_{2} \mathrm{C}_{3}\right)$ rings. The corresponding $\mathrm{AlN}_{4}$ core appears in a distorted tetrahedral geometry. The $\mathrm{Al}-\mathrm{N}$ bond lengths within the $\mathrm{AlN}_{2} \mathrm{C}_{2}$ ring are 1.807(2) $\AA(\mathrm{Al}-\mathrm{N}(\mathrm{H}))$ and 1.847(1) $\AA$ (Al$\mathrm{N}(\mathrm{Ph})$ ), respectively, and can be compared with those of the $\mathrm{AlN}_{4}$ ring complex $(1.815(2)$,

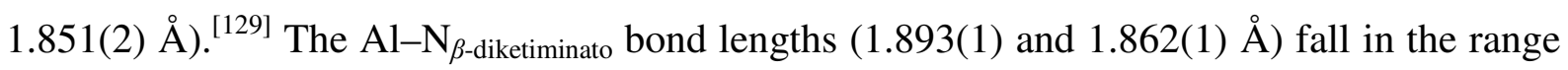
(1.874(1)-1.959(3) Å) observed for four-coordinate $\beta$-diketiminato aluminum compounds, ${ }^{[155-}$ ${ }^{156]}$ although one bond is a little shorter than these values. The $\mathrm{AlN}_{2} \mathrm{C}_{2}$ ring is nearly planar $(\Delta$ $=0.0719 \AA$ ) and this planar character can be extended to the adjacent disubstituted phenyl group $(\Delta=0.0816 \AA)$. It is interesting to note that, within the $\mathrm{AlN}_{2} \mathrm{C}_{2}$ ring, the $\mathrm{C}(31)-\mathrm{C}(36)$ bond length $(1.429(2) \AA)$ is longer compared to the remaining ones of the phenyl ring (1.382(2)-1.393(2) $\AA$ ). This obviously contributes to a ring formation of $\mathrm{AlN}_{2} \mathrm{C}_{2}$. The phenyl groups involved in different structural environments (disubstituted $\mathrm{C}_{6} \mathrm{H}_{4}, \mathrm{~N}(\mathrm{Ph}$ ), Ar) exhibit diverse resonances for the aromatic protons in the ${ }^{1} \mathrm{H}$ NMR spectrum of 17. An unambiguous assignment of the resonances was not possible. The NH resonates at $\delta 3.06$ (s) and in the IR spectrum the absorption at $3220 \mathrm{~cm}^{-1}$ is assignable to $v_{\mathrm{NH}}$.

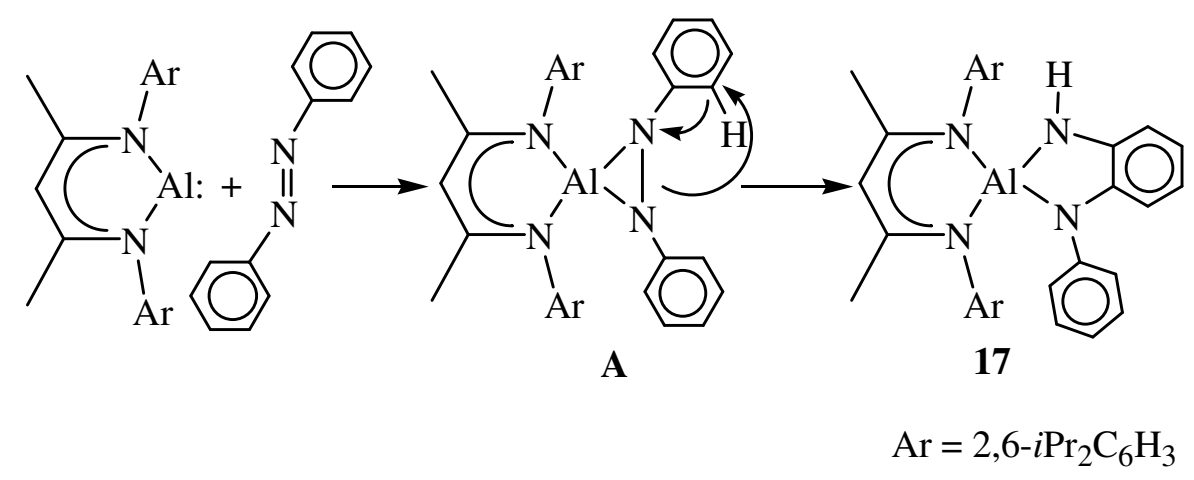

Scheme 14

The reaction of $\mathrm{LAl}$ with azobenzene may initially proceed through a $\mathrm{LAl}\left(\eta^{2}-\mathrm{N}_{2} \mathrm{Ph}_{2}\right)(\mathbf{A})$ intermediate which was formed by $[1+2]$ cycloaddition reaction. $\mathbf{A}$ is not stable due to the 
high strained metal containing three-membered $\mathrm{AlN}_{2}$ ring, and therefore rearranges by cleaving the $\mathrm{N}-\mathrm{N}$ bond under migration of a hydrogen from an ortho position of one adjacent phenyl ring to yield 17 (Scheme 14). Similar structural compounds like A are known for transition and lanthanide metals, in which the different electronic interaction modes ( $\pi$ bonds and one electron transfer) are discussed. ${ }^{[157-159]}$ A three-membered $\mathrm{AlN}_{2}$ heterocycle bearing an exocyclic $\mathrm{N}=\mathrm{C}$ double bond at one of the two $\mathrm{N}$ atoms has also been reported. ${ }^{[160]}$ Correspondingly, an easy cleavage of the $\mathrm{N}-\mathrm{N}$ bond and the rearrangement of the adjacent ortho phenyl hydrogen of azobenzene were also observed in the reaction of an $\mathrm{FeH}$ containing active site with azobenzene, ${ }^{[161-162]}$ in a cyclometalation ${ }^{[163-166]}$ and a substitution $^{[167]}$ reaction.

A further insight into this proposed mechanism is gained from theoretical calculation. ${ }^{[168]}$ The DFT (Density Funtional Theory) calculations are performed by analyzing the energy difference of products and reactants in reaction system of $\mathrm{L}^{\prime} \mathrm{Al}$ and $\mathrm{PhNNPh}$ to $\mathrm{L}^{\prime} \mathrm{Al}\left(\eta^{2}-\right.$ $\left.\mathrm{N}_{2} \mathrm{Ph}_{2}\right)$, and then to $\mathrm{L}^{\prime} \mathrm{Al}\left[\mathrm{N}(\mathrm{H})-o-\mathrm{C}_{6} \mathrm{H}_{4} \mathrm{~N}(\mathrm{Ph})\right]$, where $\mathrm{L}^{\prime}$ is modified as $\mathrm{HC}[(\mathrm{CMe})(\mathrm{NPh})]_{2}$ for simplicity of calculation and their corresponding geometries are optimized according to the real structures or related ones at BP86/TZVP level with RI approximation (L'Al to LAl, $\mathrm{PhNNPh}$ in cis position, $\mathrm{L} \cdot \mathrm{Al}\left(\eta^{2}-\mathrm{N}_{2} \mathrm{Ph}_{2}\right)$ to $\mathrm{LAl}\left(\eta^{2}-\mathrm{C}_{2} \mathrm{Ph}_{2}\right)$ but a $\mathrm{N}-\mathrm{N}$ single bond, and $\mathrm{L}^{\prime} \mathrm{Al}\left[\mathrm{N}(\mathrm{H})-o-\mathrm{C}_{6} \mathrm{H}_{4} \mathrm{~N}(\mathrm{Ph})\right]$ to $\mathrm{LAl}\left[\mathrm{N}(\mathrm{H})-o-\mathrm{C}_{6} \mathrm{H}_{4} \mathrm{~N}(\mathrm{Ph})\right]$ ) using TURBOMOLE 5.5 program. The computed results show that the complexation energy of the initial reaction of L'Al with azobenzene to $\mathrm{L}^{\prime} \mathrm{Al}\left(\eta^{2}-\mathrm{N}_{2} \mathrm{Ph}_{2}\right)$ (here $\mathrm{L}^{\prime}$ is modified as $\mathrm{HC}[(\mathrm{CMe})(\mathrm{NPh})]_{2}$ for simplicity of calculation) is ca. $-39 \mathrm{kcal} / \mathrm{mol}$ (that is $\left.\mathrm{D}_{298}\left(\mathrm{Al}-\eta^{2}-\mathrm{N}_{2}\right)=39 \mathrm{kcal} / \mathrm{mol}\right)$. This indicates a reasonable possibility of $\mathbf{A}$ as an intermediate in the reaction of LAl with azobenzene. The value of $-39 \mathrm{kcal} / \mathrm{mol}$ is even lower than that calculated for the complexation energy of LAl with alkyne (ca. $-21 \mathrm{kcal} / \mathrm{mol})$ using the same method. ${ }^{[156]}$ When $\mathrm{L}$ ' $\mathrm{Al}\left(\eta^{2}-\mathrm{N}_{2} \mathrm{Ph}_{2}\right)$ is further converted to $\mathrm{L}^{\prime} \mathrm{Al}\left[\mathrm{N}(\mathrm{H})-o-\mathrm{C}_{6} \mathrm{H}_{4} \mathrm{~N}(\mathrm{Ph})\right]$, a best estimate of the energy difference between these two isomers is $-76 \mathrm{kcal} / \mathrm{mol}$. This suggests an energetically favored stable rearrangement, and 
is also in agreement with the rearrangement of a three- to five-membered ring. Furthermore, the $\mathrm{D}_{298}\left(\mathrm{Al}-\eta^{2}-\mathrm{N}_{2}\right)$ value is comparable to that of the $\mathrm{Al}-\mathrm{N}$ bond strength in donor-acceptor $\mathrm{H}_{3} \mathrm{Al} \cdot \mathrm{NH}_{3}$ species predicted by ab initio studies with zero-point vibrational energy correction $\left(\mathrm{D}_{298}(\mathrm{Al}-\mathrm{N})=26 \mathrm{kcal} / \mathrm{mol}\right) .{ }^{[169]}$ This implies a somewhat strong $\mathrm{Al}-\eta^{2}-\mathrm{N}_{2}$ bonding. Therefore the cleavage of the corresponding $\mathrm{N}-\mathrm{N}$ bond in the rearrangement of $\mathbf{A}$ to $\mathbf{1 7}$ is highly favored although no such bond dissociation energy data are available for comparison. $^{[170]}$

Thus, the reaction of aluminum(I) monomer LAl with azobenzene has been investigated. The formation of a five-membered $\mathrm{AlN}_{2} \mathrm{C}_{2}$ ring (17) shows the difference in comparison with that of the $[1+2]$ cycloaddition product by the reaction of LAl with alkyne, and indicates an interesting rearrangement of azobenzene via a possible three-membered $\mathrm{AlN}_{2}$ intermediate (A) by interacting with LAl. 


\subsection{A Stable Aluminacyclopropene $\mathrm{LAl}\left(\eta^{2}-\mathrm{C}_{2} \mathrm{H}_{2}\right)$ and}

\section{Its End-on Azide Insertion to an Aluminaazacyclobutene}

Abstract: A stable aluminacyclopropene $L A l\left(\eta^{2}-C_{2} H_{2}\right)$ (18) has been isolated from the temperature controlled reaction of LAl with excess of $\mathrm{C}_{2} \mathrm{H}_{2} .18$ further reacts with one molecule of $\mathrm{C}_{2} \mathrm{H}_{2}$ under ring opening and formation of terminal $\mathrm{C} \equiv \mathrm{CH}$ and $\mathrm{CH}=\mathrm{CH}_{2}$ groups at aluminum to yield $\mathrm{LAl}(\mathrm{C} \equiv \mathrm{CH})\left(\mathrm{CH}=\mathrm{CH}_{2}\right)$ (19). The reaction of $\mathrm{LAl}\left(\eta^{2}-\mathrm{C}_{2} \mathrm{Ph}_{2}\right)$ with one equiv of HCCPh smoothly afforded compound $\operatorname{LAl}(C \equiv C P h)[C(P h)=C H(P h)]$ (20). This reaction was further monitored by ${ }^{1} H$ NMR spectral analysis, clearly disclosing the hydrogen migration of terminal HCCPh under the ring opening of $A l\left(\eta^{2}-C_{2}\right)$. The end-on azide insertion in the $A l\left(\eta^{2}-C_{2}\right)$ ring of 18 results in the first aluminaazabutene $\operatorname{LAl}\left[C H=C H N\left(N=N A r^{*}\right)\right]$ (21).

Heavier main group elements containing cyclopropenes have received considerable attentions due to their strained structure and remarkable reactivity. These compounds are often involved in reactions such as ring-opening, insertion, substitution, dimerization, and $[1,2]$-hydrogen migration, ${ }^{[171]}$ and therefore are of great interest in syntheses, especially in the preparation of main group elements containing larger heterocycles with $\mathrm{C}-\mathrm{C}$ unsaturated bonds.

These three-membered ring compounds with organic substituents at the two olefinic carbon atoms have been known. ${ }^{[155,160,171-175]}$ However species with the simplest $\mathrm{M}\left(\eta^{2}-\mathrm{C}_{2} \mathrm{H}_{2}\right)$ moiety are either discussed on the basis of theoretical calculations, ${ }^{[176-180]}$ or observed in metal vapor deposition reactions at $12 \mathrm{~K} .{ }^{[181]} \mathrm{Et}\left(\right.$ solvent) $\mathrm{Al}\left(\eta^{2}-\mathrm{C}_{2} \mathrm{Ph}_{2}\right)$ (solvent: $\mathrm{Et}_{2} \mathrm{O}$, THF) and $\operatorname{ClAl}\left(\eta^{2}-\mathrm{C}_{2} \mathrm{R}_{2}\right)(\mathrm{R}=\mathrm{Me}, \mathrm{Et})$ were assumed as intermediates in the respective formation of 1,4(dialumina)cyclohexadiene and $(\mathrm{ClAl} \cdot \mathrm{RC} \equiv \mathrm{CR})_{4} \cdot{ }^{[182-185]}$ Subsequently the bulky $\beta$ diketiminato ligand $\mathrm{L}$ stabilizes the $\mathrm{Al}\left(\eta^{2}-\mathrm{C}_{2} \mathrm{R}^{1} \mathrm{R}^{2}\right)\left(\mathrm{L}=\mathrm{HC}[(\mathrm{CMe})(\mathrm{NAr})]_{2}\right.$, $\mathrm{Ar}=2,6-$ $\left.\left.i \mathrm{Pr}_{2} \mathrm{C}_{6} \mathrm{H}_{3}\right) ; \mathrm{R}^{1}, \mathrm{R}^{2}: \mathrm{SiMe}_{3}, \mathrm{Ph}\right)$ rings. Such compounds have been prepared by the reductive coupling reaction of $\mathrm{LAlI}_{2}$ and potassium in the presence of $\mathrm{R}^{1} \mathrm{C} \equiv \mathrm{CR}^{2} \cdot{ }^{[155]}$ Correspondingly, 
$\mathrm{XAl}\left(\eta^{2}-\mathrm{C}_{2} \mathrm{H}_{2}\right)(\mathrm{X}=\mathrm{H}, \mathrm{Cl})$ are suggested by calculations, however, they are unstable, as indicated by IR and ESR data on matrix isolated species at low temperatures. ${ }^{[179-180]}$ Herein, we show the reaction of the aluminum(I) monomer, $\mathrm{LAl}^{[95]}$ with $\mathrm{C}_{2} \mathrm{H}_{2}$ in the range from low to room temperature, and the successful isolation of the first stable aluminacyclopropene $\operatorname{LAl}\left(\eta^{2}-\mathrm{C}_{2} \mathrm{H}_{2}\right)$ (18) and its subsequent reaction product $\mathrm{LAl}(\mathrm{C} \equiv \mathrm{CH})\left(\mathrm{CH}=\mathrm{CH}_{2}\right)$ (19). The reaction of $\mathbf{1 8}$ with a large bulky organic azide leads to an unusual insertion product, an aluminaazacyclobutene $\mathrm{LAl}[\mathrm{CH}=\mathrm{CHN}(\mathrm{N}=\mathrm{NAr} *)]\left(\mathbf{2 1}, \mathrm{Ar} *=2,6-\mathrm{Ar}_{2}{ }_{2} \mathrm{C}_{6} \mathrm{H}_{3}, \mathrm{Ar}{ }^{\prime}=2,4,6-\right.$ $\left.\mathrm{Me}_{3} \mathrm{C}_{6} \mathrm{H}_{2}\right)$.

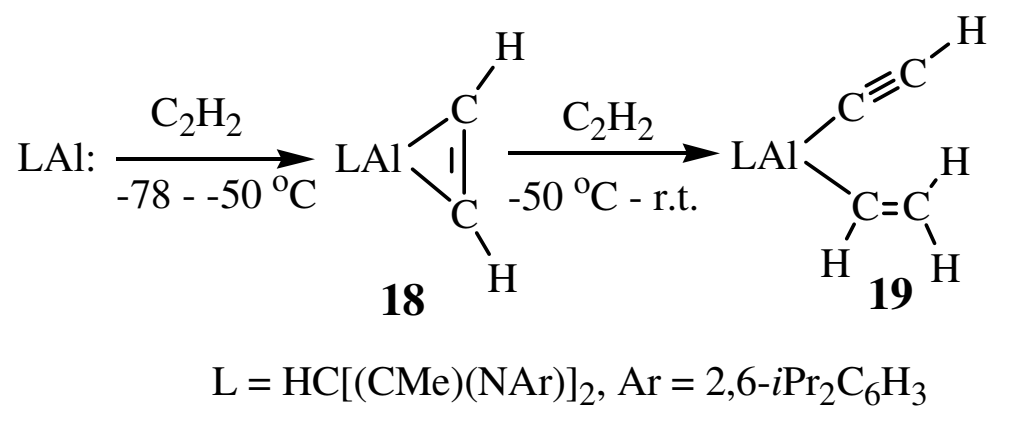

\section{Scheme 15}

The reaction of LAl with excess of carefully dried $\mathrm{C}_{2} \mathrm{H}_{2}$ in toluene was initially carried out in the range from $-78{ }^{\circ} \mathrm{C}$ to room temperature. The instant color change of the solution from red to orange and then the slow change to almost colorless were clearly observed, and compound $\mathrm{LAl}(\mathrm{C} \equiv \mathrm{CH})\left(\mathrm{CH}=\mathrm{CH}_{2}\right)(\mathbf{1 9})$ was formed. Obviously, the formation of 19 indicated that LAl reacted with two molecules of $\mathrm{C}_{2} \mathrm{H}_{2}$. When this reaction was controlled in the temperature range from -78 to $-50{ }^{\circ} \mathrm{C}$, the red solution only changed to orange (this color change even occurred when this reaction was performed at ca. $-100{ }^{\circ} \mathrm{C}$ ). By removal of unreacted $\mathrm{C}_{2} \mathrm{H}_{2}$, a 1:1 adduct $\operatorname{LAl}\left(\eta^{2}-\mathrm{C}_{2} \mathrm{H}_{2}\right)(\mathbf{1 8})$ was isolated (Scheme 15). It is noted that when this reaction was continued without removing excess of $\mathrm{C}_{2} \mathrm{H}_{2}$, the corresponding ${ }^{1} \mathrm{H}$ NMR spectrum has shown the formation of small amounts of 19, whereas the reaction solution remained orange in color. 
The formation of $\mathbf{1 8}$ essentially follows [1 +2] cycloaddition with respect to the characters of $\mathrm{LAl}$ (one nonbonded electron pair at $\mathrm{Al}$ ) and $\mathrm{C}_{2} \mathrm{H}_{2}(\mathrm{C} \equiv \mathrm{C} \pi$ electrons). The interaction between $\mathrm{C}_{2}$ and $\mathrm{Al}$, in view of the theoretical molecular collision mechanism, gives the two extreme types: $\mathrm{C}_{2}$ center to $\mathrm{Al}$ (channel a), and one of the $\mathrm{C}$ atoms of $\mathrm{C}_{2}$ to $\mathrm{Al}$ (channel b). The DFT calculations by analyzing the total potential energy of LAl plus $\mathrm{C}_{2} \mathrm{H}_{2}$ system versus $\mathrm{Al} \cdots \mathrm{C}$ distance show that channel a has an energy barrier (the most height at ca. $145 \mathrm{~kJ} / \mathrm{mol}$ ), while b has almost no barrier (Figure 10). Obviously, the reaction kinetically takes channel b, which means that reaction can occur almost without any energy supporting. This is in good agreement with our experimental observations. Moreover, the final calculations of the reaction energy of $\mathrm{LAl}$ and $\mathrm{C}_{2} \mathrm{H}_{2}$ to $\mathbf{1 8}$ (ca. $155 \mathrm{~kJ} / \mathrm{mol}$ ) imply a stronger $\mathrm{Al}-\eta^{2}-\mathrm{C}_{2} \mathrm{H}_{2}$ bond in comparison to that of the disubstituted one $\left(\mathrm{Al}-\eta^{2}-\mathrm{C}_{2} \mathrm{R}^{1} \mathrm{R}^{2}\right.$, ca. $\left.88 \mathrm{~kJ} / \mathrm{mol}\right) .{ }^{[155]}$

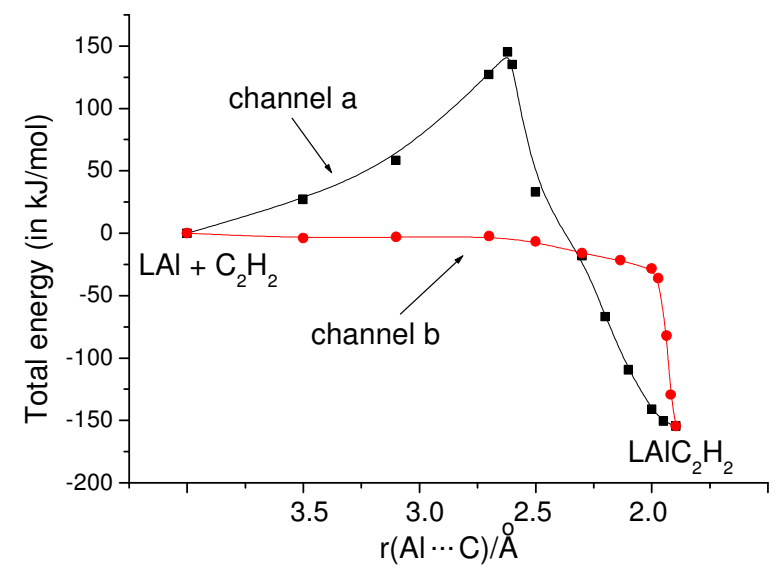

Figure 10. The total potential energy curve of $\mathrm{LAl}$ and $\mathrm{C}_{2} \mathrm{H}_{2}$ versus the $\mathrm{Al} \cdots \mathrm{C}$ distance.

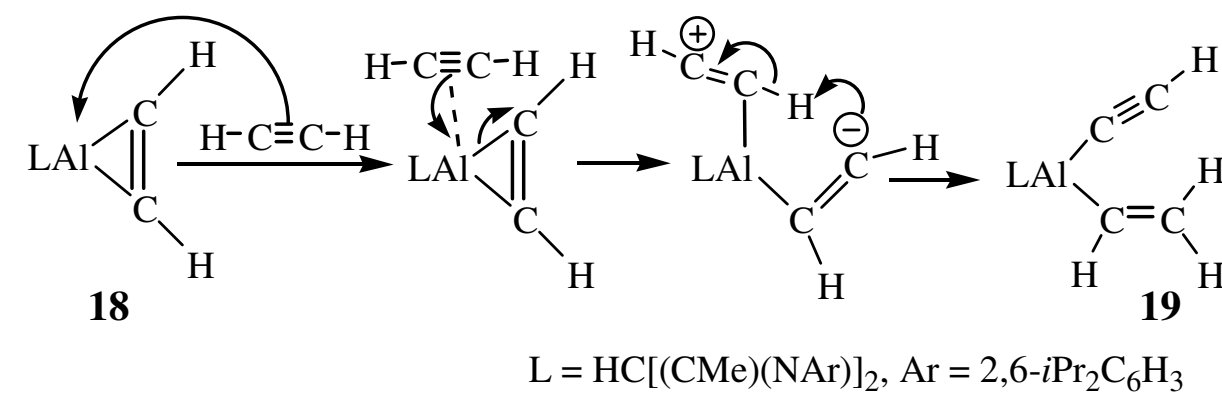

\section{Scheme 16}

Further reaction of $\mathbf{1 8}$ with $\mathrm{C}_{2} \mathrm{H}_{2}$ may proceed through a donor-acceptor intermediate due to the Lewis acidic $\mathrm{Al}$ center of $\mathbf{1 8}$. This mechanism has been extensively discussed in the 
reaction of alkylaluminum(III) or alkylaluminum hydride compounds with alkynes, ${ }^{[4]}$ and further evidenced by some experimental data. ${ }^{[186-188]}$ The ring opening of $\operatorname{Al}\left(\eta^{2}-\mathrm{C}_{2}\right)$ may occur with concomitant hydrogen migration from the $\pi$-coordinated $\mathrm{C}_{2} \mathrm{H}_{2}$ to result in $\mathbf{1 9}$ (Scheme 16). The latter ${ }^{1} \mathrm{H}$ NMR monitored reaction of $\mathrm{LAl}\left(\eta^{2}-\mathrm{C}_{2} \mathrm{Ph}_{2}\right)$ with a little excess of $\mathrm{HCCPh}$ to compound $\mathrm{LAl}(\mathrm{C} \equiv \mathrm{CPh})[\mathrm{C}(\mathrm{Ph})=\mathrm{CH}(\mathrm{Ph})]$ (20) may clearly give a similar insight into this process.

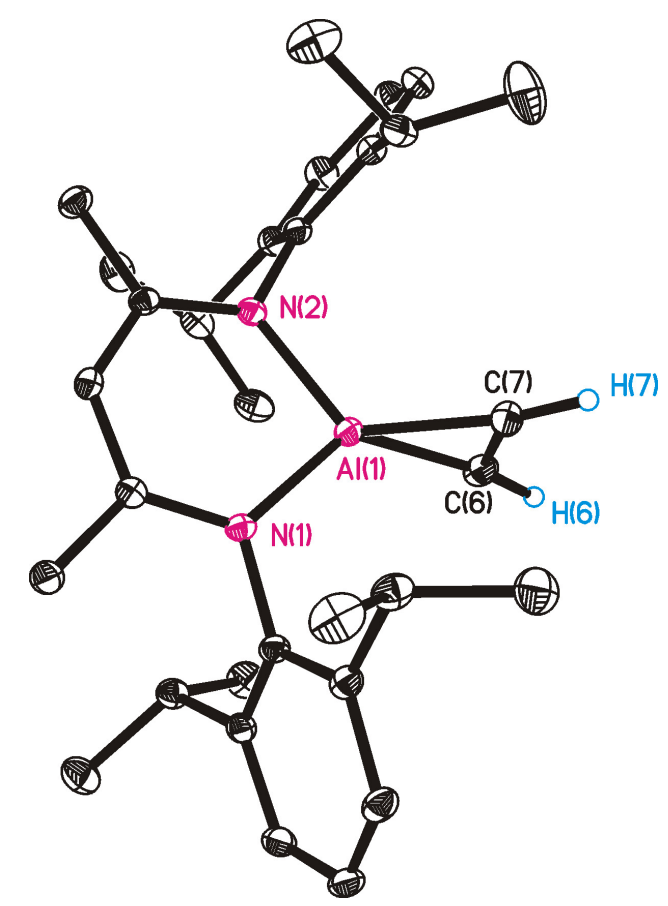

Figure 12. Molecular structure of 18. $\mathrm{H}$ atoms in $\mathrm{L}$ are omitted for clarity. Selected bond lengths $(\AA)$ and angles $\left({ }^{\circ}\right)$ : $\mathrm{Al}(1)-\mathrm{N}(1) 1.875(1), \mathrm{Al}(1)-\mathrm{N}(2)$ 1.884(1), $\mathrm{Al}(1)-\mathrm{C}(6) 1.885(2)$,

$$
\begin{gathered}
\mathrm{Al}(1)-\mathrm{C}(7) 1.878(2), \mathrm{C}(6)-\mathrm{C}(7) 1.358(2), \mathrm{C}(6)-\mathrm{H}(6) 1.000, \mathrm{C}(7)-\mathrm{H}(7) 1.021, \\
\mathrm{~N}(1)-\mathrm{Al}(1)-\mathrm{N}(2) 97.98(5), \mathrm{C}(6)-\mathrm{Al}(1)-\mathrm{C}(7) 42.30(7), \mathrm{Al}(1)-\mathrm{C}(6)-\mathrm{C}(7) 68.57(10), \\
\mathrm{Al}(1)-\mathrm{C}(7)-\mathrm{C}(6) 69.13(10), \mathrm{H}(6)-\mathrm{C}(6)-\mathrm{C}(7) 126.4, \mathrm{H}(7)-\mathrm{C}(7)-\mathrm{C}(6) 127.1 .
\end{gathered}
$$

Compound $\mathbf{1 8}$ was obtained as an orange crystalline solid in quantitative yield. $\mathbf{1 8}$ is extremely air-sensitive. Its solution, once exposed to air, immediately changes its orange color to colorless. However, it is stable in an inert gas atmosphere. $\mathbf{1 8}$ is readily soluble in aromatic solvents and sparingly soluble in $n$-hydrocarbons. Compound $\mathbf{1 9}$ is a colorless crystalline 
solid and is well soluble in hydrocarbons. 18 and 19 were characterized by mass spectrometry, ${ }^{1} \mathrm{H}$ and ${ }^{13} \mathrm{C}$ NMR spectroscopy, and by X-ray crystallography.

The structural analyses clearly reveal that compound 18 has a three-membered $\operatorname{Al}\left(\eta^{2}\right.$ $\mathrm{C}_{2} \mathrm{H}_{2}$ ) ring (Figure 11), while 19 contains terminal $\mathrm{C} \equiv \mathrm{CH}$ and $\mathrm{CH}=\mathrm{CH}_{2}$ groups at the $\mathrm{Al}$ atom (Figure 12). The latter is the first crystallographic authenticated example with terminal $\mathrm{C} \equiv \mathrm{CH}$ and $\mathrm{CH}=\mathrm{CH}_{2}$ groups at the same $\mathrm{Al}$ atom. In 19, the X-ray reflection data indicate that both $\mathrm{C} \equiv \mathrm{CH}$ and $\mathrm{CH}=\mathrm{CH}_{2}$ groups are disordered in two positions $(\mathrm{C}(6) \mathrm{H}(6) \mathrm{C}(7) \mathrm{H}(7) \mathrm{H}(8)$, $\mathrm{C}(8) \mathrm{C}(9) \mathrm{H}(9), 62.2 \% ; \mathrm{C}(6 \mathrm{~A}) \mathrm{H}(6 \mathrm{~A}) \mathrm{C}(7 \mathrm{~A}) \mathrm{H}(7 \mathrm{~A}) \mathrm{H}(8 \mathrm{~A}), \mathrm{C}(8 \mathrm{~A}) \mathrm{C}(9 \mathrm{~A}) \mathrm{H}(9 \mathrm{~A}), 37.8 \%)$. Thus, the central $\mathrm{Al}$ atom appears in a disordered tetrahedral geometry with $\mathrm{N}-\mathrm{Al}-\mathrm{N}$ bond angle of

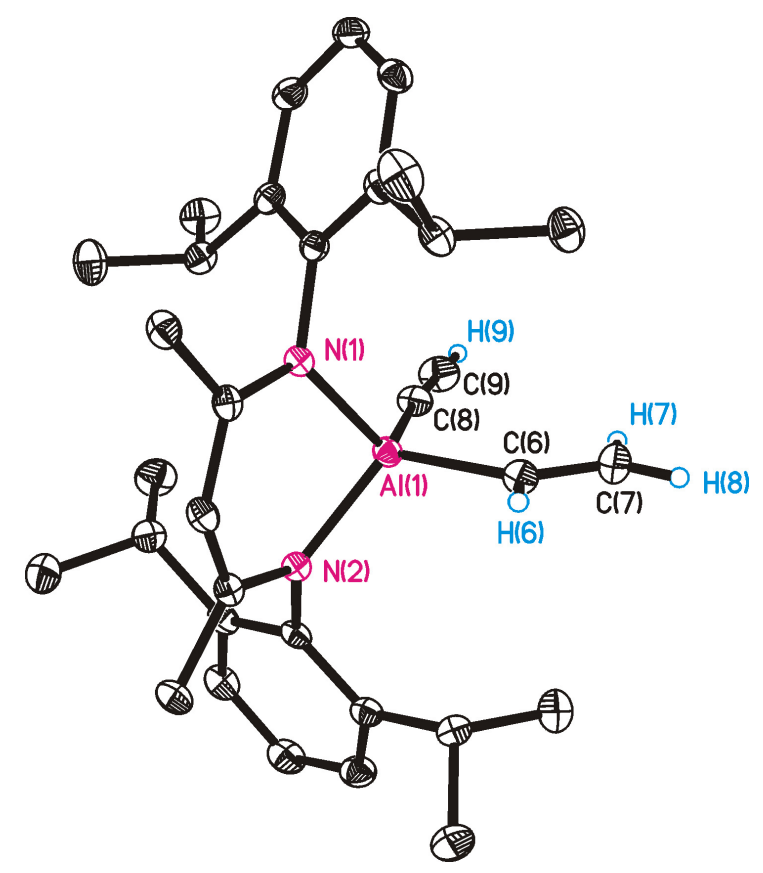

Figure 13. Molecular structure of $\mathbf{1 9}$, the $\mathrm{C} \equiv \mathrm{CH}$ and $\mathrm{CH}=\mathrm{CH}_{2}$ groups both in $62.2 \%$ occupation. $\mathrm{H}$ atoms in $\mathrm{L}$ are omitted for clarity. Selected bond lengths $(\AA)$ and angles $\left({ }^{\circ}\right)$ :

$$
\begin{aligned}
& \mathrm{Al}(1)-\mathrm{N}(1) 1.910(2), \mathrm{Al}(1)-\mathrm{N}(2) 1.895(1), \mathrm{Al}(1)-\mathrm{C}(6) 1.944(11), \mathrm{Al}(1)-\mathrm{C}(8) 1.962(11), \\
& \mathrm{C}(6)-\mathrm{C}(7) 1.325(17), \mathrm{C}(8)-\mathrm{C}(9) 1.173(11), \mathrm{N}(1)-\mathrm{Al}(1)-\mathrm{N}(2) 96.99(6), \mathrm{C}(6)-\mathrm{Al}(1)-\mathrm{C}(8) \\
& 110.8(4), \mathrm{Al}(1)-\mathrm{C}(6)-\mathrm{C}(7) 124.6(12), \mathrm{Al}(1)-\mathrm{C}(8)-\mathrm{C}(9) 173.9(13) .
\end{aligned}
$$

96.99(6) ${ }^{\circ}$ and $\mathrm{C}-\mathrm{Al}-\mathrm{C}$ angles of $111.6(5)^{\circ}$ (av). The $\mathrm{Al}-\mathrm{N}$ bond lengths in $\mathbf{1 8}(1.875(1)$,

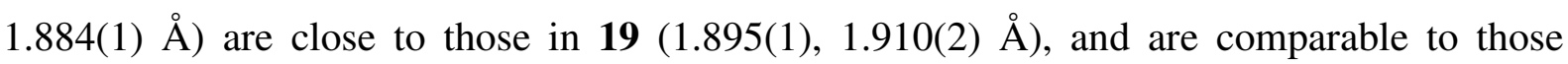


observed in compounds with four coordinate $\beta$-diketiminato aluminum(III) (1.888(2)-1.935(2) $\AA$ ). However, they are shorter, in contrast to the longer Al-N bonds in LAl (1.957(2) $\AA$ ) due to the larger radius of the $\mathrm{Al}(\mathrm{I})^{[95]}$ compared to that of $\mathrm{Al}(\mathrm{III})$.

In 19, the $\mathrm{Al}-\mathrm{C}$ bond lengths $\left(\mathrm{Al}-\mathrm{C}_{\mathrm{C} \equiv \mathrm{C}}, 1.941(14) \AA(\mathrm{av}) ; \mathrm{Al}-\mathrm{C}_{\mathrm{C}=\mathrm{C}}, 1.954(14) \AA(\mathrm{av})\right)$ are comparable to those in related compounds $\mathrm{LAlMe}_{2}(1.955(4)-1.961(3) \AA)$ and $\mathrm{L}^{\prime} \mathrm{AlMe}_{2}\left(\mathrm{~L}^{\prime}=\right.$ $\left.\mathrm{HC}[(\mathrm{CMe})(\mathrm{N}-p-\mathrm{tol})]_{2}, 1.958(3)-1.970(3) \AA\right)$. The $\mathrm{C} \equiv \mathrm{C}(1.170(14) \AA(\mathrm{av}))$ and $\mathrm{C}=\mathrm{C}$ bond distances $(1.323(18) \AA(a v))$ are indicative of characteristic $\mathrm{C}-\mathrm{C}$ triple and double bonds, while the $\mathrm{Al}-\mathrm{C} \equiv \mathrm{C}\left(175.4(19)^{\circ}(\mathrm{av})\right)$ and $\mathrm{Al}-\mathrm{C}=\mathrm{C}\left(124.6(14)^{\circ}(\mathrm{av})\right)$ angles deviate from the ideal $180^{\circ}$ and $120^{\circ}$, respectively. ${ }^{[189]}$ The ${ }^{1} \mathrm{H}$ and ${ }^{13} \mathrm{C}$ NMR spectra of 19 confirm the functional $\mathrm{CH}=\mathrm{CH}_{2}$ and $\mathrm{C} \equiv \mathrm{CH}$ groups at $\mathrm{Al}$. In $\mathrm{CH}=\mathrm{CH}_{2}$, the corresponding protons resonate at $\delta$ 5.70-6.20 ppm and carbons at $\delta 125.4\left(=\mathrm{CH}_{2}\right)$ and $138.0(\mathrm{br}, \mathrm{Al}-\mathrm{CH}=) \mathrm{ppm}$, respectively, and are within the typical alkenyl range. Three groups of double doublets are indicative for three non-equivalent protons. While the latter exhibits the proton resonance at $\delta 1.55$ (s) ppm and carbon resonances at $\delta 94.6(\mathrm{br}, \equiv \mathrm{CH})$ and 137.3 (br, $\mathrm{Al}-\mathrm{C} \equiv)$ ppm. The absorptions at 1996 and $3270 \mathrm{~cm}^{-1}$ in the IR spectrum of $\mathbf{1 9}$ are tentatively assigned to the stretching frequencies of $\mathrm{C} \equiv \mathrm{C}$ and $\equiv \mathrm{C}-\mathrm{H}$ bonds.

In 18, the parameters within $\mathrm{Al}\left(\eta^{2}-\mathrm{C}_{2} \mathrm{H}_{2}\right)$ moiety (Al-C 1.882(2) $\AA$ (av), C-C 1.358(2) $\AA$, C-H $1.010 \AA$ (av); C-Al-C 42.30(7) ${ }^{\circ}, \mathrm{Al}-\mathrm{C}-\mathrm{C}$ 68.85(10) ${ }^{\circ}$ (av), H-C-C, $126.6^{\circ}$ (av)) fit well when compared with those of $\mathrm{Al}\left(\eta^{2}-\mathrm{C}_{2}\right)$ in $\mathrm{LAl}\left(\eta^{2}-\mathrm{C}_{2} \mathrm{R}^{1} \mathrm{R}^{2}\right)\left(\mathrm{R}^{1}, \mathrm{R}^{2}: \mathrm{SiMe}_{3}, \mathrm{Ph}\right)(\mathrm{Al}-\mathrm{C}$

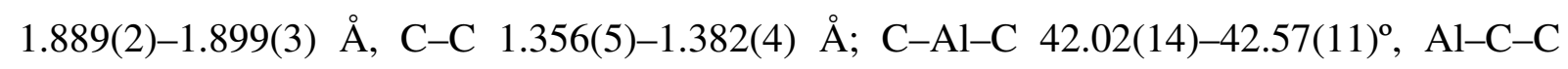
$\left.68.39(15)-68.80(19)^{\circ}\right),{ }^{[155]}$ and are also much closer to those in the calculated $\operatorname{HAl}\left(\eta^{2}-\mathrm{C}_{2} \mathrm{H}_{2}\right)$

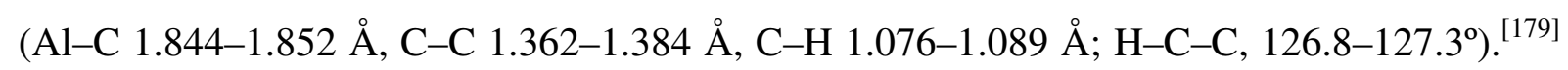
It is noteworthy that in the $\mathrm{Al}\left(\eta^{2}-\mathrm{C}_{2} \mathrm{H}_{2}\right)$ ring of $\mathbf{1 8}$ the average $\mathrm{Al}-\mathrm{C}$ and $\mathrm{C}-\mathrm{C}$ bond lengths are respectively shorter and longer than those in $\mathbf{1 9}$ (deviation of 0.072 and $0.036 \AA$ ). This may indicate a conjugated ring system in $\mathrm{Al}\left(\eta^{2}-\mathrm{C}_{2}\right)$. Furthermore, the ${ }^{1} \mathrm{H}$ and ${ }^{13} \mathrm{C}$ NMR spectra recorded in $\mathrm{C}_{6} \mathrm{D}_{6}$ show the proton $(\delta 8.82(\mathrm{~s}) \mathrm{ppm})$ and carbon resonances $(177.2(\mathrm{br}) \mathrm{ppm})$ of 
the $\mathrm{Al}\left(\eta^{2}-\mathrm{C}_{2} \mathrm{H}_{2}\right)$ moiety in the low-field region characteristic for the alkenyl system. The results are indicative for a certain aromatic character of the $\mathrm{Al}\left(\eta^{2}-\mathrm{C}_{2}\right)$ ring.

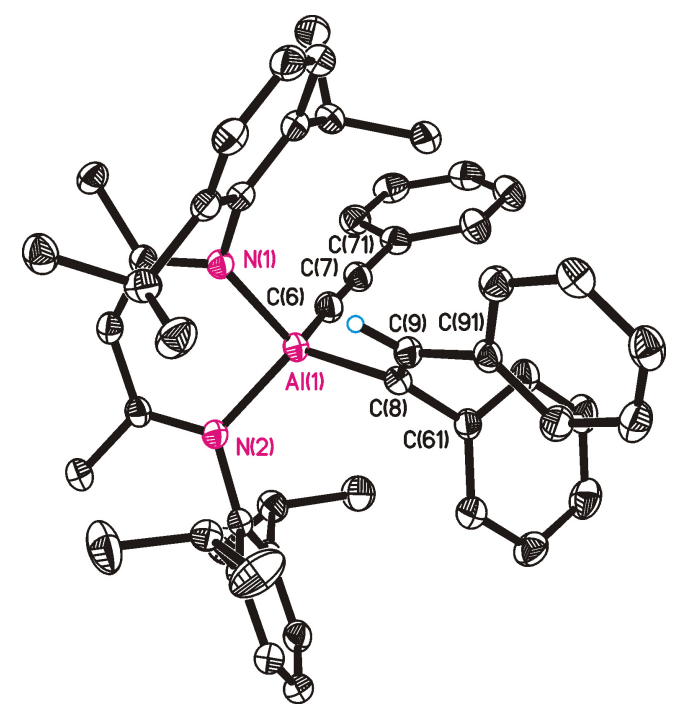

Figure 14. Molecular structure of 20. Selected bond lengths $(\AA)$ and angles $\left({ }^{\circ}\right)$ : $\mathrm{Al}(1)-\mathrm{N}(1)$

$$
\begin{aligned}
& \text { 1.894(2), } \mathrm{Al}(1)-\mathrm{N}(2) 1.895(2), \mathrm{Al}(1)-\mathrm{C}(6) 1.941(2), \mathrm{Al}(1)-\mathrm{C}(8) 1.971(2), \mathrm{C}(6)-\mathrm{C}(7) \\
& 1.217(2), \mathrm{C}(8)-\mathrm{C}(9) 1.343(3), \mathrm{N}(1)-\mathrm{Al}(1)-\mathrm{N}(2) 97.04(6), \mathrm{C}(6)-\mathrm{Al}(1)-\mathrm{C}(8) 111.15(8)
\end{aligned}
$$

The reaction of $\mathrm{LAl}\left(\eta^{2}-\mathrm{C}_{2} \mathrm{Ph}_{2}\right)$ with one equiv of $\mathrm{HCCPh}$ smoothly afforded compound $\mathrm{LAl}(\mathrm{C} \equiv \mathrm{CPh})[\mathrm{C}(\mathrm{Ph})=\mathrm{CH}(\mathrm{Ph})](\mathbf{2 0})$. The molecular structure of $\mathbf{2 0}$ is presented in Figure 14 .

\section{(I)}

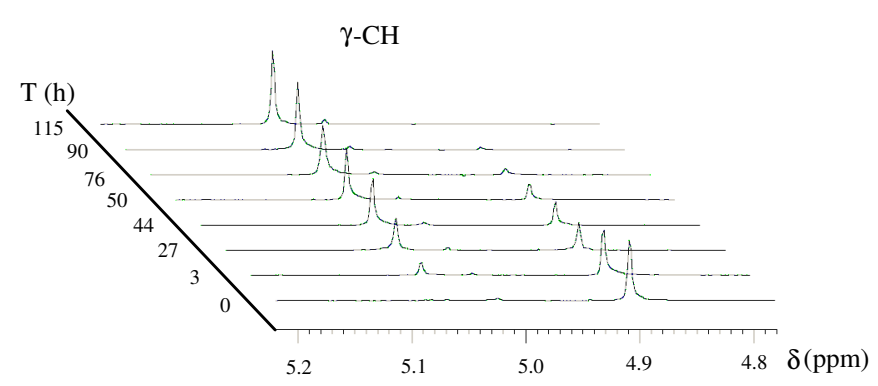

(II)

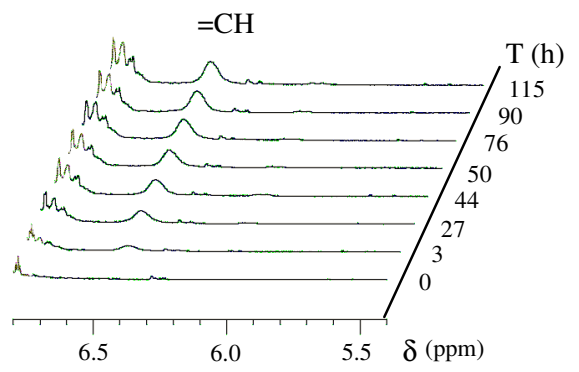

Figure 15. The ${ }^{1} \mathrm{H}$ NMR spectra monitored reaction of $\mathrm{LAl}\left(\eta^{2}-\mathrm{C}_{2} \mathrm{Ph}_{2}\right)$ with $\mathrm{HCCPh}$ 
This reaction was further monitored by ${ }^{1} \mathrm{H}$ NMR spectral analysis (Figure 15). (I) clearly shows the gradual consumption of starting material $\mathrm{LAl}\left(\eta^{2}-\mathrm{C}_{2} \mathrm{Ph}_{2}\right)$ and formation of product 20 by the indication of $\gamma-\mathrm{CH}$ of $\mathrm{LAl}$ moiety with reaction time. (II) reflects the gradual generation of olefinic proton corresponding to $\mathrm{AlC}(\mathrm{Ph})=\mathrm{CH}(\mathrm{Ph})$ moiety, indicating the hydrogen migration from $\mathrm{HCCPh}$ molecule.

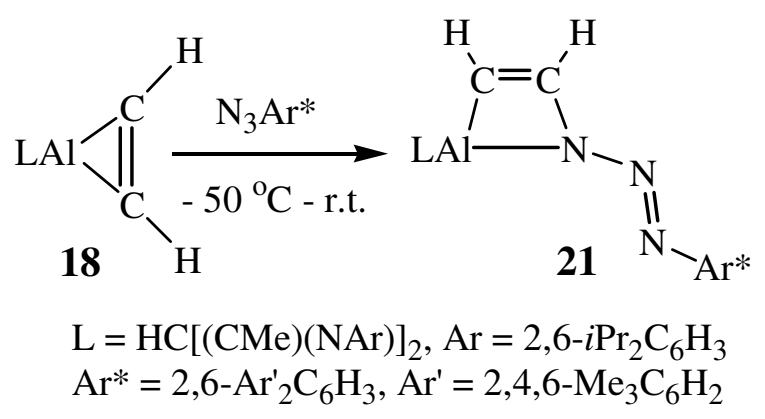

Scheme 17

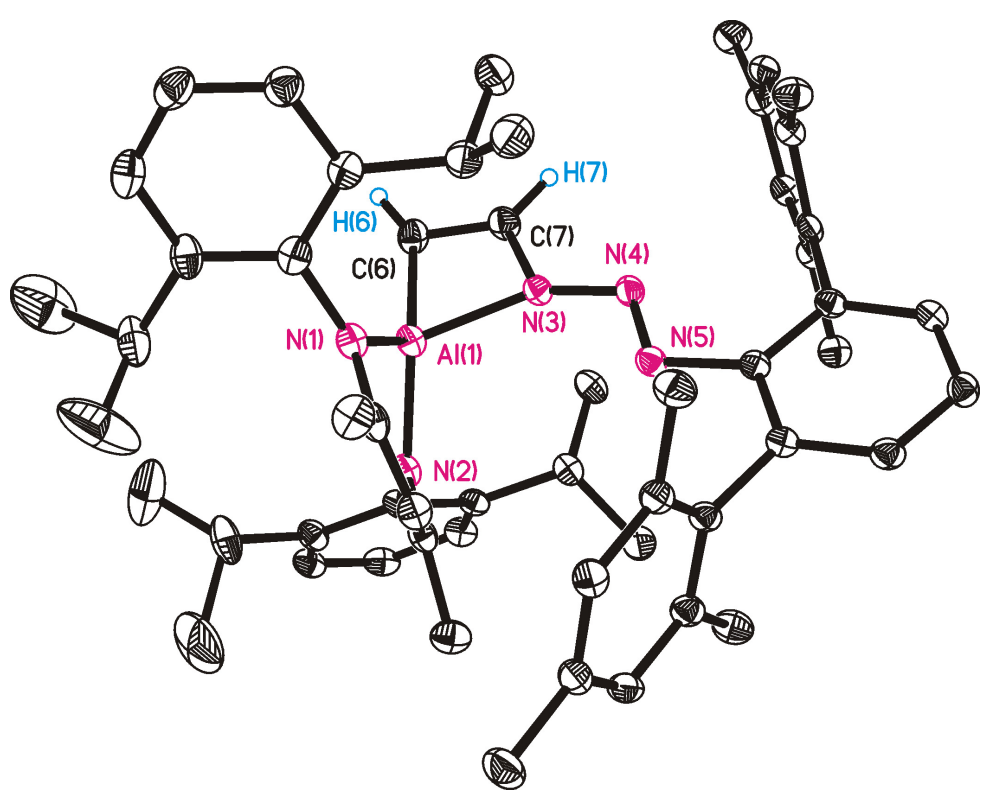

Figure 16. Molecular structure of 21. $\mathrm{H}$ atoms in $\mathrm{L}$ are omitted for clarity. Selected bond lengths $(\AA)$ and angles $\left({ }^{\circ}\right)$ : $\mathrm{Al}(1)-\mathrm{N}(1)$ 1.866(2), $\mathrm{Al}(1)-\mathrm{N}(2)$ 1.867(2), $\mathrm{Al}(1)-\mathrm{N}(3)$ 1.892(2), $\mathrm{Al}(1)-\mathrm{C}(6) 1.932(3), \mathrm{C}(6)-\mathrm{C}(7) 1.342(4), \mathrm{C}(7)-\mathrm{N}(3) 1.410(3), \mathrm{N}(3)-\mathrm{N}(4) 1.320(3)$,
$\mathrm{N}(4)-\mathrm{N}(5) 1.284(3), \mathrm{N}(1)-\mathrm{Al}(1)-\mathrm{N}(2) 99.8(1), \mathrm{C}(6)-\mathrm{Al}(1)-\mathrm{N}(3) 72.6(1), \mathrm{Al}(1)-\mathrm{N}(3)-\mathrm{C}(7)$
$88.2(2), \mathrm{Al}(1)-\mathrm{C}(6)-\mathrm{C}(7) 88.5(2), \mathrm{C}(6)-\mathrm{C}(7)-\mathrm{N}(3) 110.7(2), \mathrm{N}(3)-\mathrm{N}(4)-\mathrm{N}(5) 112.4(2)$. 
The reaction of $\mathbf{1 8}$ with a large bulky azide $\mathrm{N}_{3} \mathrm{Ar}^{*}$ exhibits an unusual end-on azide insertion, resulting in a four-membered aluminaazacyclobutene 21 (Scheme 17). There are a handful of reactions known between monovalent organo-group 13 compounds and organic azides. ${ }^{[124,127,129-130,190-192]}$ The initial $\mathrm{N}_{2}$ elimination is generally accepted, and supported by the experimental observation. The formation of a five-membered $\mathrm{AlN}_{4}$ ring in $\mathrm{LAl}\left[\left(\mathrm{NSiMe}_{3}\right)_{2} \mathrm{~N}_{2}\right]$ was suggested proceeding through a $[2+3]$ cycloaddition of an $\mathrm{Al}=\mathrm{N}$ intermediate and $\mathrm{N}_{3} \mathrm{SiMe}_{3}$. While the disubstituted aluminacyclopropene $\operatorname{LAl}\left[\left(\eta^{2}-\mathrm{C}_{2}\left(\mathrm{SiMe}_{3}\right)_{2}\right]\right.$ reacted under disassociation and $\mathrm{N}_{2}$ elimination with a similar bulky azide to an $\mathrm{Al}=\mathrm{N}$ compound. ${ }^{[155]}$ Accordingly, the end-on $\mathrm{N}_{3} \mathrm{Ar} *$ insertion in the $\mathrm{Al}\left(\eta^{2}-\mathrm{C}_{2}\right)$ ring unambiguously reveals the initial interaction between an $\mathrm{Al}$ center and the end-on $\mathrm{N}$ atom of the azide group. This type of reaction is, to the best of our knowledge, so far unknown. Compound $\mathbf{2 1}$ has been well characterized by spectroscopic, analytical, and X-ray crystal measurements. The molecular structure of $\mathbf{2 1}$ is viewed in Figure 16.

In general, the first stable aluminacyclopropene $\operatorname{LAl}\left(\eta^{2}-\mathrm{C}_{2} \mathrm{H}_{2}\right)(\mathbf{1 8})$ has been prepared by the direct reaction of LAl with $\mathrm{C}_{2} \mathrm{H}_{2}$ and structurally characterized. The crystallographic and NMR spectral data of $\mathbf{1 8}$ indicate a delocalized $\mathrm{Al}\left(\eta^{2}-\mathrm{C}_{2}\right)$ heterocycle, which can be described as a Hückel $2 \pi$ aromatic system. The subsequent reaction of $\mathbf{1 8}$ with $\mathrm{C}_{2} \mathrm{H}_{2}$ to $\mathbf{1 9}$ shows its high reactivity. The end-on $\mathrm{N}_{3} \mathrm{Ar} *$ insertion in the $\mathrm{Al}\left(\eta^{2}-\mathrm{C}_{2} \mathrm{H}_{2}\right)$ ring of $\mathbf{1 8}$ to the aluminaazacyclobutene $\mathbf{2 1}$ exhibits a novel reaction pattern of aluminacyclopropenes, and reflects the unusual trapping ability of $\mathbf{1 8}$. Further investigation of the reactivity of $\mathbf{1 8}$ is underway. 


\subsection{A Seven-membered Aluminum Allenyl Sulfur Heterocycle Arising from the Conversion of an Aluminacyclopropene with $\mathbf{C S}_{\mathbf{2}}$}

Abstract: The reaction of an aluminacyclopropene $\mathrm{LAl}\left[\eta^{2}-\mathrm{C}_{2}\left(\mathrm{SiMe}_{3}\right)_{2}\right]\left(\mathrm{L}=\mathrm{HC}(\mathrm{CMeNAr})_{2}\right.$, $\left.\mathrm{Ar}=2,6-\mathrm{Pr}_{2} \mathrm{C}_{6} \mathrm{H}_{3}\right)$ with $\mathrm{CS}_{2}$ in the temperature range from $-78{ }^{\circ} \mathrm{C}$ to room temperature affords the first seven-membered aluminum sulfur containing heterocyclic compound $\left[\mathrm{LAl}_{2}(\mu-\mathrm{S})\left[\eta^{2}-\mathrm{SC}\left(\mathrm{SiMe}_{3}\right)=C=C\left(\mathrm{SiMe}_{3}\right)\right]\right.$ (24) bearing an allenyl group. The structural characterization of 24 and the analogous compound $\mathrm{LAl}\left[\mathrm{OC}(\mathrm{O}) \mathrm{C}_{2} \mathrm{R}_{2}\right]\left(\mathrm{R}=\mathrm{Ph}(\mathbf{2 2}), \mathrm{SiMe}_{3}\right.$ (23)) of the proposed intermediate $\boldsymbol{A}$ and the variable-temperature ${ }^{1} H$ NMR kinetic study of this reaction may give a better understanding on this unusual conversion.

There is a widespread interest in main group heterocyclic compounds due to their applications in pharmaceutical, agrochemical, and material science. ${ }^{[154]}$ In recent years, the number of group 13 metal heterocycles has increased. Within the heterocycles those containing multiple bonds have shown interesting structural features and properties. The $\mathrm{M}^{\mathrm{n}} \mathrm{N}_{2} \mathrm{C}_{2}(\mathrm{M}=\mathrm{Al}, \mathrm{Ga}, \mathrm{In}, \mathrm{n}=2 ; \mathrm{M}=\mathrm{Ga}, \mathrm{n}=1,3)^{[193-198]}$ and $\mathrm{MC}_{3} \mathrm{~N}_{2}(\mathrm{M}=\mathrm{Al}, \mathrm{Ga})^{[95,199]}$ heterocycles with $\mathrm{C}=\mathrm{C}$ or $\mathrm{C}=\mathrm{N}$ double bonds are exhibiting high electron density. The threemembered $\mathrm{AlC}_{2}$ ring with a $\mathrm{C}=\mathrm{C}$ bond shows a highly strained structure and good reactivity. ${ }^{[155]}$ Nonetheless, such species are rare, and the heteroatoms within cycle are limited to $\mathrm{C}, \mathrm{N}$, and $\mathrm{O}$ elements due to the lack of appropriate synthetic routes. Herein we report on a seven-membered $\mathrm{Al}_{2} \mathrm{C}_{3} \mathrm{~S}_{2}$ heterocycle bearing a $\mathrm{C}=\mathrm{C}=\mathrm{C}$ allenyl group prepared from the reaction of an aluminacyclopropene, $\operatorname{LAl}\left[\eta^{2}-\mathrm{C}_{2}\left(\mathrm{SiMe}_{3}\right)_{2}\right]\left(\mathrm{L}=\mathrm{HC}(\mathrm{CMeNAr})_{2}, \mathrm{Ar}=2,6-\right.$ $i \mathrm{Pr}_{2} \mathrm{C}_{6} \mathrm{H}_{3}$ ) with carbon disulfide. Interestingly, the unusual formation of the allenyl group, to the best of our knowledge, is hitherto unknown in organoaluminum chemistry.

The addition of neat carbon disulfide to the solution of $\mathrm{LAl}\left[\eta^{2}-\mathrm{C}_{2}\left(\mathrm{SiMe}_{3}\right)_{2}\right]$ in toluene was carried out at $-78{ }^{\circ} \mathrm{C}$. In the course of warming the solution to room temperature, the color changed from red-black to green, to yellow green, and finally to yellow. An additional stirring for $12 \mathrm{~h}$ resulted in the formation of $\mathbf{2 4}$. 
The initial reaction of $\mathrm{LAl}\left[\eta^{2}-\mathrm{C}_{2}\left(\mathrm{SiMe}_{3}\right)_{2}\right]$ with $\mathrm{CS}_{2}$ resembles closely to that of $\mathrm{LAl}\left[\eta^{2}-\right.$ $\left.\mathrm{C}_{2} \mathrm{R}_{2}\right]\left(\mathrm{R}=\mathrm{Ph}, \mathrm{SiMe}_{3}\right)$ with $\mathrm{CO}_{2}($ Scheme 18$),{ }^{[155]}$ resulting in the generation of the fivemembered heterocycle LAl[SC(S)C $\left.{ }_{2}\left(\mathrm{SiMe}_{3}\right)_{2}\right](\mathbf{A})$. Obviously, A further interacts with a

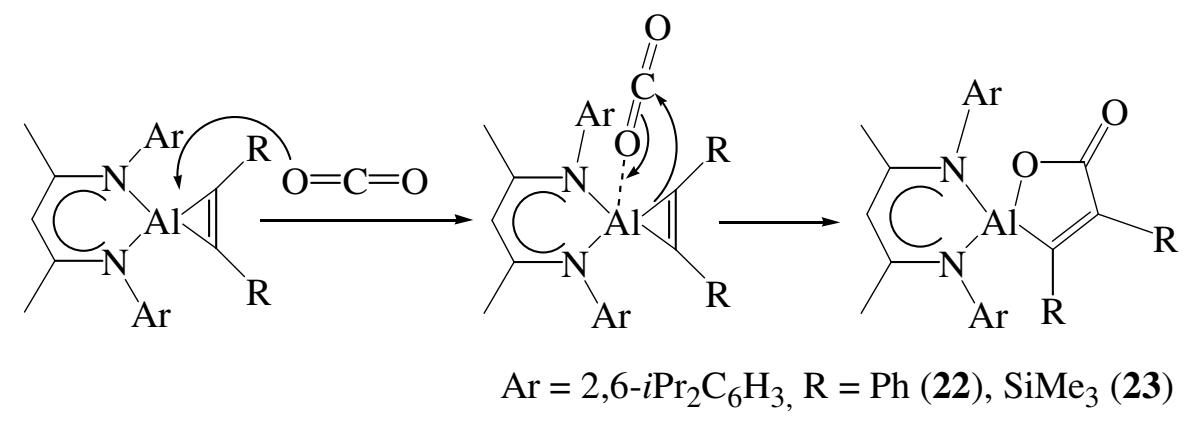

Scheme 18

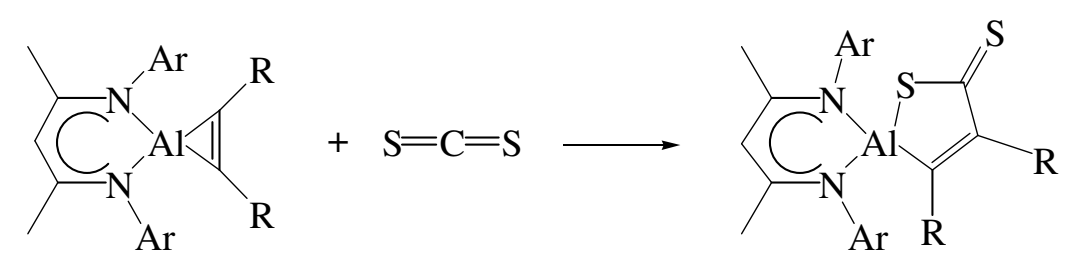

S

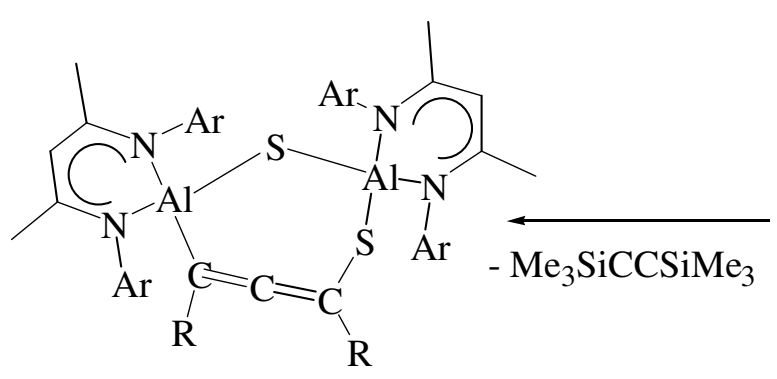

24

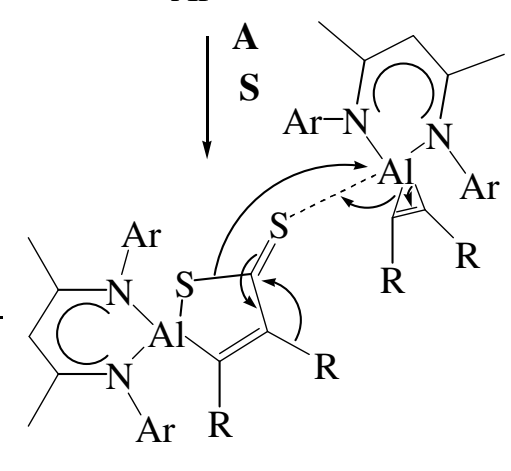

B

$$
\mathrm{Ar}=2,6-i \mathrm{Pr}_{2} \mathrm{C}_{6} \mathrm{H}_{3}, \mathrm{R}=\mathrm{SiMe}_{3}
$$

Scheme 19

second molecule of $\mathrm{LAl}\left[\eta^{2}-\mathrm{C}_{2}\left(\mathrm{SiMe}_{3}\right)_{2}\right]$ at the donor exocyclic $\mathrm{S}$ atom in $\mathbf{A}$ and the acceptor $\mathrm{Al}$ center in $\mathrm{LAl}\left[\eta^{2}-\mathrm{C}_{2}\left(\mathrm{SiMe}_{3}\right)_{2}\right]$ to give intermediate $(\mathbf{B})$. The fact whether one equivalent or excess of $\mathrm{CS}_{2}$ was employed, only product $\mathbf{2 4}$ was isolated, indicates the stronger competitive reaction of $\mathbf{A}$ with $\mathrm{LAl}\left[\eta^{2}-\mathrm{C}_{2}\left(\mathrm{SiMe}_{3}\right)_{2}\right]$ than with $\mathrm{CS}_{2}$. $\mathbf{B}$ reacts further under elimination of one molecule of $\mathrm{Me}_{3} \mathrm{SiCCSiMe}_{3}$ due to the weak $\mathrm{Al}-\eta^{2}-\mathrm{C}_{\text {alkyne }}$ bonding (the bond dissociation energy of $\mathrm{Al}-\eta^{2}-\mathrm{C}_{2}$ is only $95.8 \mathrm{~kJ} / \mathrm{mol}$ and therefore much less than that of $\mathrm{Al}-\mathrm{C}_{\mathrm{methyl}}$ in $\mathrm{AlMe}_{3}{ }^{[4]}\left(\mathrm{D}_{\text {average }}, 281.4 \mathrm{~kJ} / \mathrm{mol}\right)$. The free $\mathrm{Me}_{3} \mathrm{SiCCSiMe}_{3}$ is detected in the latter ${ }^{1} \mathrm{H} \mathrm{NMR}$ 
kinetic study. An easy migration of one $\mathrm{Me}_{3} \mathrm{Si}$ group ${ }^{[200]}$ and rearrangement of $\mathrm{C}=\mathrm{S}_{\text {exo }}$ and $\mu$ S-C bonds lead to the unique formation of the thioallenyl functional group and the final product 24. A proposed mechanism for the formation of $\mathbf{2 4}$ is given in Scheme 19. A parallel investigation of $\mathrm{LAl}\left[\eta^{2}-\mathrm{C}_{2}\left(\mathrm{SiMe}_{3}\right)_{2}\right]$ with $\mathrm{S}_{8}$ resulted in the formation of a dimer $[\mathrm{LAlS}]_{2}$.. Evidently, the bulky $\beta$-diketiminato ligand with the steric and electronic stabilizing properties acts as an optimal skeleton for the aluminum center throughout the reaction process.

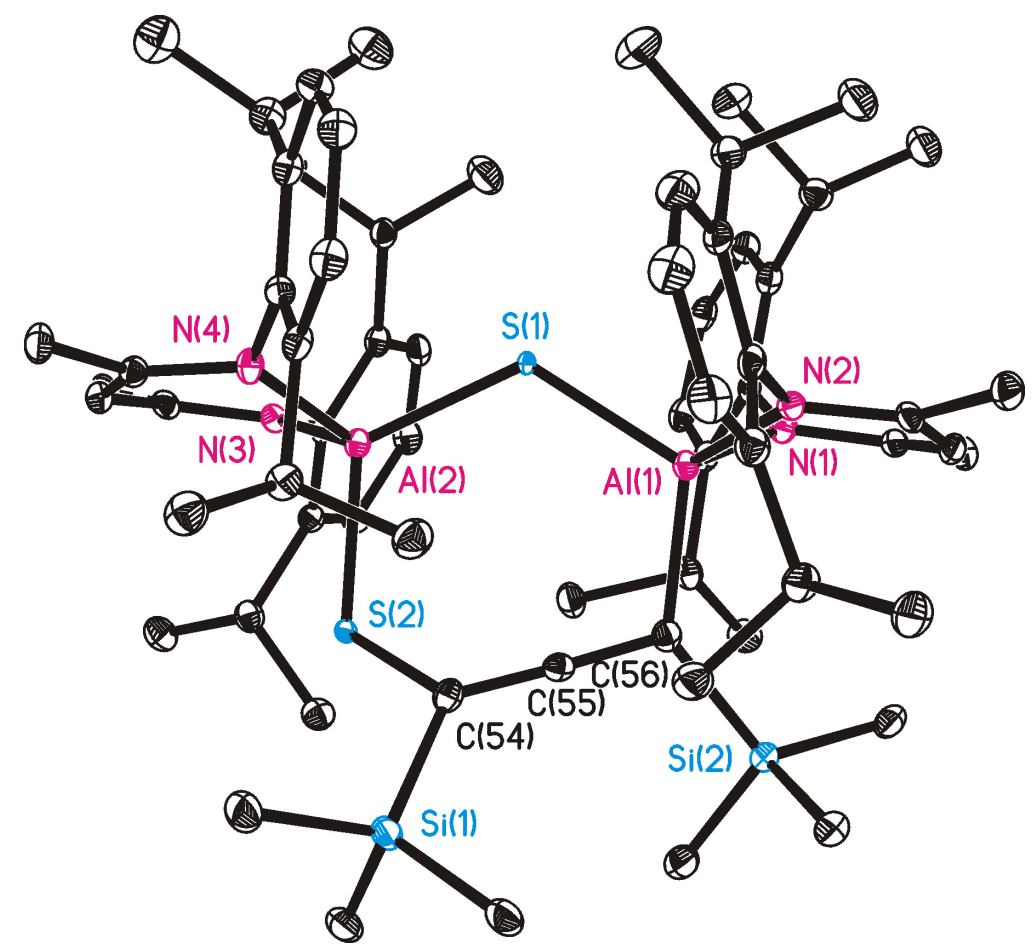

Figure 17. Molecular structure of $\mathbf{2 4}$ (without H atoms). Selected bond lengths $(\AA)$ and angles $\left.{ }^{\circ}\right): \mathrm{Al}(1)-\mathrm{S}(1) 2.2298(11), \mathrm{Al}(1)-\mathrm{C}(56)$ 1.990(3), $\mathrm{Al}(2)-\mathrm{S}(1) 2.2188(11), \mathrm{Al}(2)-\mathrm{S}(2)$ 2.2270(11), S(2)-C(54) 1.809(3), C(54)-C(55) 1.325(4), C(55)-C(56) 1.316(4);

$$
\mathrm{Al}(1)-\mathrm{S}(1)-\mathrm{Al}(2) 122.57(4), \mathrm{C}(54)-\mathrm{C}(55)-\mathrm{C}(56) 178.0(3) .
$$

Compound 24 was obtained as yellow crystals, which were characterized by spectroscopy and by X-ray crystallography. The structural analysis of $\mathbf{2 4}$ reveals a novel heterocyclic molecule (Figure 17), which is in sharp contrast to those of known dinuclear aluminum sulfides or thiolates. Each aluminum atom is chelated by a $\beta$-diketiminato ligand to form LAl moieties. Between the two $\mathrm{LAl}$, one $\mathrm{S}$ atom and one $\mathrm{SC}\left(\mathrm{SiMe}_{3}\right) \mathrm{CC}\left(\mathrm{SiMe}_{3}\right)$ group are forming 
each a bridge. The bond lengths of $\mathrm{Al}-\mathrm{S}_{\text {bridge }}(2.2188(11), 2.2298(11) \AA)$ and $\mathrm{Al}-\mathrm{S}_{\text {thioallenyl }}$ $(2.2270(11) \AA)$ are in the range $(2.10-2.30 \AA)$ of dinuclear aluminum sulfides. However, the bond angle of $\mathrm{Al}(1)-\mathrm{S}(1)-\mathrm{Al}(2)\left(122.57(4)^{\circ}\right)$ is the widest among those of dinuclear aluminum sulfides or thiolates $\left(78.1-117.5^{\circ}\right) .{ }^{[201-202]}$ The two central $\mathrm{Al}$ atoms, the $\mu$-S atom and the SCCC group constitute one seven-membered $\mathrm{Al}_{2} \mathrm{C}_{3} \mathrm{~S}_{2}$ ring, of which $\mathrm{S}(2), \mathrm{Al}(2), \mathrm{S}(1)$, $\mathrm{Al}(1)$ and $\mathrm{C}(56)$ are arranged within a plane (mean deviation $\Delta=0.0375 \AA$ ), while the $\mathrm{C}(56) \mathrm{C}(55) \mathrm{C}(54)$ group is located outside of this plane. The remarkable feature of $\mathbf{2 4}$ is the $\mathrm{SC}\left(\mathrm{SiMe}_{3}\right) \mathrm{CC}\left(\mathrm{SiMe}_{3}\right)$ group. The similar adjacent $\mathrm{C}-\mathrm{C}$ bond distances $(1.316(4), 1.325(4) \AA)$ and the almost linear $\mathrm{C}-\mathrm{C}-\mathrm{C}$ angle $\left(178.0(3)^{\circ}\right)$ indicate the $\mathrm{C}=\mathrm{C}=\mathrm{C}$ allenyl functionality. $\mathrm{A}$ comparable example is only observed in trans $\left.-\mathrm{Rh}\left[\eta-\mathrm{C}\left(\mathrm{CH}=\mathrm{CH}_{2}\right)=\mathrm{C}=\mathrm{CPh}_{2}\right](\mathrm{CO})\left(\mathrm{P}-i \mathrm{Pr}_{3}\right)_{2}\right]$ (1.308(6), 1.332(6) $\AA$ and $\left.177.5(5)^{\circ}\right) .{ }^{[203]}$ The IR spectrum shows one weak band $\left(1840 \mathrm{~cm}^{-1}\right)$ assignable to this bridged thioallenyl group. The deliberate ${ }^{13} \mathrm{C}$ NMR spectral studies give an unambiguous assignment of such allenyl $\left(\mathrm{Al}-\mathrm{C}\left(\mathrm{SiMe}_{3}\right)=\mathrm{C}=\mathrm{C}\left(\mathrm{SiMe}_{3}\right) \mathrm{S}\right)$ carbon resonances $(\delta$ $212.70(=C=) ; 80.60, \operatorname{broad}(\mathrm{Al}-C=) ; 59.94 \mathrm{ppm}(=C-\mathrm{S}))$.

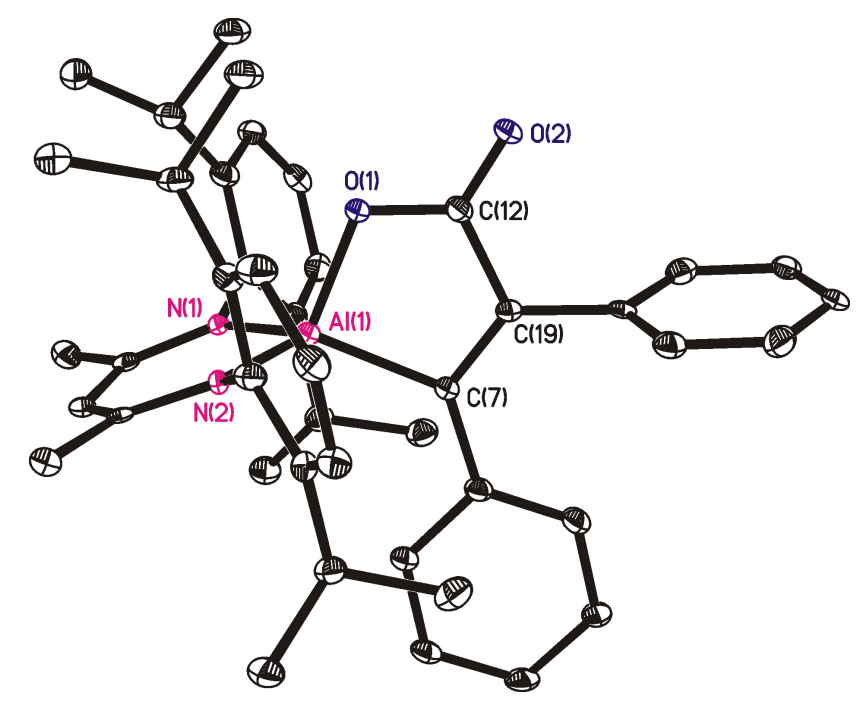

Figure 18. Molecular structure of 22 (without H atoms). Selected bond lengths ( $\mathrm{A}$ ) and angles $\left(^{\circ}\right): \mathrm{Al}(1)-\mathrm{O}(1) 1.776(3), \mathrm{Al}(1)-\mathrm{C}(7) 1.987(5), \mathrm{C}(12)-\mathrm{O}(1)$ 1.328(5), $\mathrm{C}(12)-\mathrm{O}(2) 1.213(6)$ $\mathrm{C}(12)-\mathrm{C}(19)$ 1.513(6), C(19)-C(7) 1.362(6); O(1)-C(12)-O(2) 122.5(4). 
The crystal structure evidence of $\mathbf{2 2}$ and $\mathbf{2 3}$ may approach to that of $\mathbf{A}$ (Figures 18 and 19). As expected, the $\mathrm{CO}_{2}$ was inserted into one of the Al-C bonds to form a five-membered $\mathrm{AlC}_{3} \mathrm{O}$ planar ring with an exo $\mathrm{C}=\mathrm{O}$ group $(\Delta=0.0199 \AA)$. The longer bond distances and weaker bond strength of $\mathrm{CS}_{2}$ than those of the corresponding $\mathrm{CO}_{2}{ }^{[204-205]}$ might give rise to the further interaction of $\mathbf{A}$ with $\operatorname{LAl}\left[\eta^{2}-\mathrm{C}_{2}\left(\mathrm{SiMe}_{3}\right)_{2}\right]$ and rearrangement of the $\mathrm{C}=\mathrm{S}_{\text {exo }}$ unit.

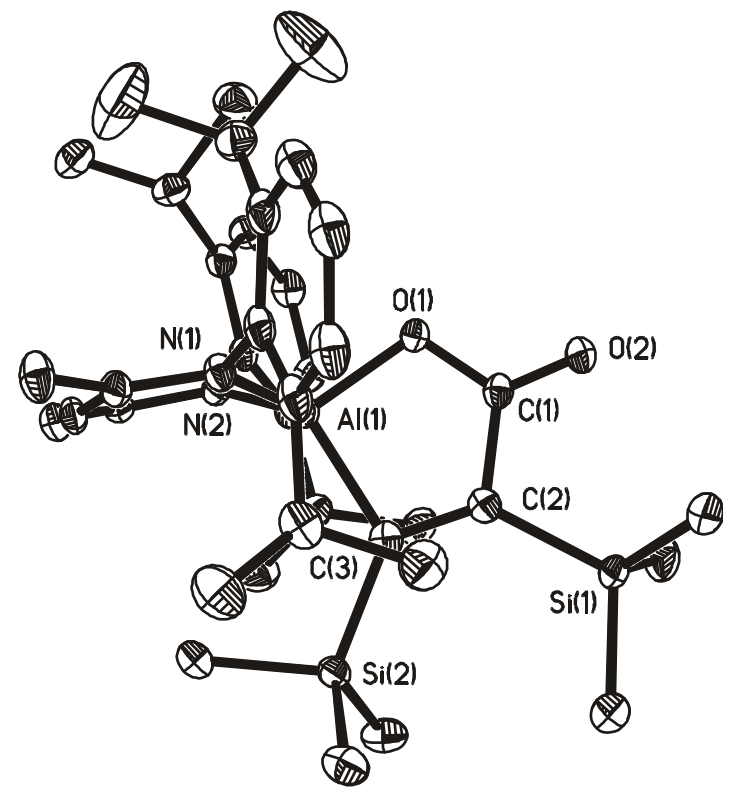

Figure 19. Molecular structure of $\mathbf{2 3}$ (without H atoms). Selected bond lengths $(\AA)$ and angles $\left.{ }^{\circ}\right): \mathrm{Al}(1)-\mathrm{O}(1) 1.7696(12), \mathrm{Al}(1)-\mathrm{C}(3)$ 1.9891(17), C(1)-O(1) 1.331(2), C(1)-O(2) 1.218(2),

$$
\mathrm{C}(1)-\mathrm{C}(2) \text { 1.530(2), } \mathrm{C}(2)-\mathrm{C}(3) 1.364(2) ; \mathrm{O}(1)-\mathrm{C}(1)-\mathrm{O}(2) 121.78(15) .
$$

The variable-temperature ${ }^{1} \mathrm{H}$ NMR spectroscopy regarding the reaction of $\mathrm{LAl}\left[\eta^{2}\right.$ $\left.\mathrm{C}_{2}\left(\mathrm{SiMe}_{3}\right)_{2}\right]$ and excess of $\mathrm{CS}_{2}$ in $\left[\mathrm{D}_{8}\right]$ toluene was monitored. The assignments of Ib, Ic, IIf and IIg were referenced to the ${ }^{1} \mathrm{H}$ NMR spectra of 24. The assignment of free $\mathrm{Me}_{3} \mathrm{SiCCSiMe}_{3}$ (Id) was referenced to the ${ }^{1} \mathrm{H}$ NMR spectrum of the commercially available $\mathrm{Me}_{3} \mathrm{SiCCSiMe}_{3}$ in $\left[\mathrm{D}_{8}\right]$ toluene at room temperature $\left(\delta_{\mathrm{SiMe} 3}=0.14 \mathrm{ppm}\right)$. From $-20{ }^{\circ} \mathrm{C}$ to $80{ }^{\circ} \mathrm{C}$, that the gradual completion of (IIf) and (IIg) proceeds the coalescence to separation is temperature-dependant. The less than 1:1 integral intensity of $\mathbf{2 4}$ to the free $\mathrm{Me}_{3} \mathrm{SiCCSiMe}_{3}$ might be due to excess of $\mathrm{CS}_{2}$, since traces of $\mathrm{CS}_{2}$ are difficult to control in the ${ }^{1} \mathrm{H}$ NMR experiment. 
This variable-temperature ${ }^{1} \mathrm{H}$ NMR kinetic study of this reaction (Figure 20) reveals the gradual consumption of $\mathrm{LAl}\left[\eta^{2}-\mathrm{C}_{2}\left(\mathrm{SiMe}_{3}\right)_{2}\right]$ (a) and formation of $\mathbf{2 4}$ (b and c) including the byproduct $\mathrm{Me}_{3} \mathrm{SiCCSiMe}_{3}$ (d) in (I). While in (II), this process is accompanied by the occurrence and quick disappearance of some resonances, indicating that this conversion proceeds via the proposed intermediates $\mathbf{A}$ and $\mathbf{B}$ to completion.
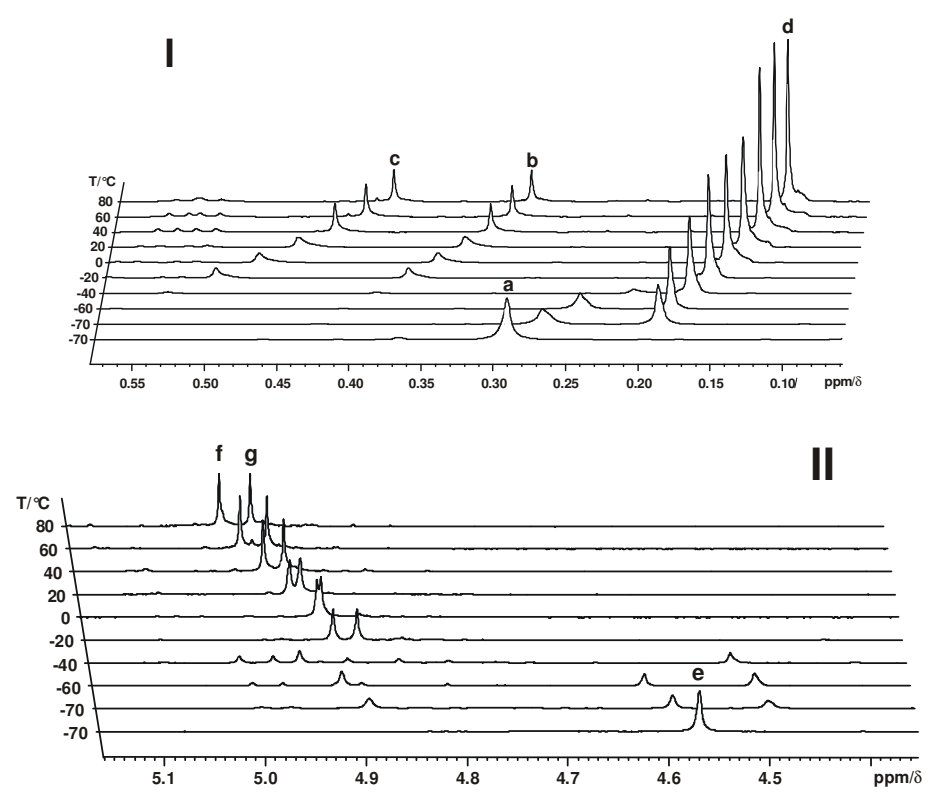

Figure 20. Variable-temperature ${ }^{1} \mathrm{H}$ NMR kinetic studies of the reaction of $\operatorname{LAl}\left[\eta^{2}\right.$ $\left.\mathrm{C}_{2}\left(\mathrm{SiMe}_{3}\right)_{2}\right]$ with excess $\mathrm{CS}_{2}$ in $\left[\mathrm{D}_{8}\right]$ toluene. (I) records the resonances of $\mathrm{SiMe}_{3}(0.10-0.55$ ppm) which correlate with changes of $\eta^{2}-\mathrm{C}_{2}\left(\mathrm{SiMe}_{3}\right)_{2}$ group and (II) shows those of $\gamma$-CH protons (4.4-5.1 ppm) directly with the changes of LAl moieties (a and e correspond to $\mathrm{LAl}\left[\eta^{2}-\mathrm{C}_{2}\left(\mathrm{SiMe}_{3}\right)_{2}\right], \mathrm{b}, \mathrm{c}, \mathrm{f}$ and $\mathrm{g}$ to $\mathbf{2 4}, \mathrm{d}$ to free $\left.\mathrm{Me}_{3} \mathrm{SiCCSiMe}_{3}\right)$.

Thus, an unusual conversion of $\operatorname{LAl}\left[\eta^{2}-\mathrm{C}_{2}\left(\mathrm{SiMe}_{3}\right)_{2}\right]$ with $\mathrm{CS}_{2}$ to $\mathbf{2 4}$ has been shown, where the search of sterically and energetically favored unsaturated substrate $\mathrm{CS}_{2}$ is crucial. The investigation on such selenium or tellurium containing heterocycles is in progress. 


\subsection{Two Types of Intramolecular Addition of an Al=N Multiple}

\section{Bonded Monomer LAl=NAr' Arised from the reaction of LAl with $\mathrm{N}_{3} A \mathbf{A}^{\prime}$}

Abstract: The reaction of $\beta$-diketiminated aluminum(I) monomer LAl with a large bulky azide $N_{3} A r^{\prime}\left(L=H C(C M e N A r)_{2}, A r^{\prime}=2,6-A r_{2} C_{6} H_{3}, A r=2,6-i P r_{2} C_{6} H_{3} 25\right.$ and 26, which have been characterized by spectroscopic and X-ray structural analyses, as well as elemental analysis. The variable-temperature ${ }^{1} H$ NMR kinetic studies of this reaction indicate the existence of the monomer LAINAr' (A) at low temperature and the thermal stability of the compounds increases in the order of $A<25<26$.

Considerable attention has been attracted to the heavier group 13 imides, since they can be used as single-source precursors for metal nitrides, which have interesting electronic properties and therefore important applications for technological materials. ${ }^{[206]}$ In recent years, studies of the syntheses and characterization of such compounds have shown that they have a strong tendency to associate, even to oligomerize. However, the modification of the substituents on both metal and nitrogen of the $(\mathrm{MN})_{\mathrm{n}}$ core have a great effect on their aggregation. The preparation of di- and tri-coordinate imido monomers Ar'MNL', $(\mathrm{M}=\mathrm{Ga}$, In; $\left.A r^{\prime}=2,6-\mathrm{Ar}_{2} \mathrm{C}_{6} \mathrm{H}_{3}, \mathrm{Ar}=2,6-i \mathrm{Pr}_{2} \mathrm{C}_{6} \mathrm{H}_{3}, \mathrm{~L}^{\prime \prime}=2,6-(4-t \mathrm{Bu}-\mathrm{Xyl})_{2} \mathrm{C}_{6} \mathrm{H}_{3}\right)$ and LMNL' $(\mathrm{M}=\mathrm{Al}$, $\mathrm{Ga} ; \mathrm{L}=\mathrm{HC}[(\mathrm{CMe})(\mathrm{NAr})]_{2}, \mathrm{~L}^{\prime}=2,6-\operatorname{Trip}_{2} \mathrm{C}_{6} \mathrm{H}_{3}$, Trip $\left.=2,4,6-i \operatorname{Pr}_{3} \mathrm{C}_{6} \mathrm{H}_{2}\right)$, which have the lowest degree of association and the unique $\mathrm{M}-\mathrm{N}$ multiple bond, demonstrates the stabilization of $\mathrm{Al}$ (Ga or In) imido monomers by the large bulky ligands. ${ }^{[191]}$ Nonetheless, the syntheses of compounds containing a $\mathrm{Ga}_{2} \mathrm{~N}_{2}$ or a $\mathrm{AlN}_{4}$ ring, ${ }^{[129,190]}$ which are proposed to proceed through the monomeric $\mathrm{Al}(\mathrm{Ga})$ imide, in the absence of steric protection, suggests the high reactivity of such monomers. Herein we show that the latent reactivity of a monomeric Al-N multiple bonded species initiates further intramolecular addition. The reaction of the $\beta$ diketiminated LAl with the bulky $\mathrm{N}_{3}$ Ar' can afford two different isomers $\mathbf{2 5}$ and $\mathbf{2 6}$ derived from their parent imide LAINAr' (A). Also of great interest is the thermal conversion of $\mathbf{2 5}$ into 26. This indicates the difference of the thermal stability between $\mathbf{2 5}$ and $\mathbf{2 6}$. 
The reaction of $\mathrm{LAl}$ with $\mathrm{N}_{3} \mathrm{Ar}$ ' was carried out at $-78{ }^{\circ} \mathrm{C}$ and allowed to warm to room temperature. Partial removal of toluene and addition of $n$-hexane led to crystallization of compounds 26 (colorless crystals in 24\% yield) and $\mathbf{2 5}$ (yellowish crystals in $42 \%$ yield), one after the other. Crystals of $\mathbf{2 5}$ are of X-ray quality, while single crystals of $\mathbf{2 6}$ were obtained when 25 was treated by dissolving in a hot toluene/n-hexane mixture and then kept at $4{ }^{\circ} \mathrm{C}$ to allow to crystallize. This suggests that a thermal conversion of $\mathbf{2 5}$ to $\mathbf{2 6}$ is occuring.

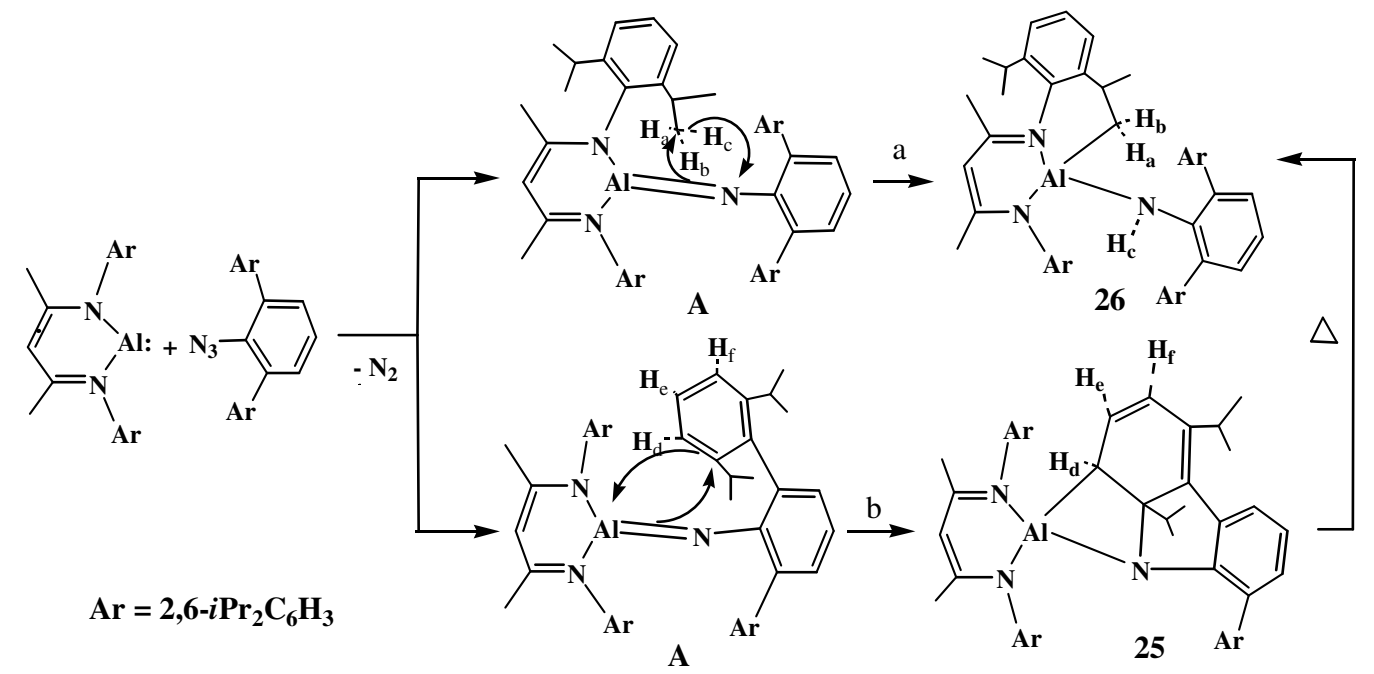

Scheme 20

The LAl reacting with $\mathrm{N}_{3}$ Ar' may proceed through an intermediate LAlNAr' (A) with elimination of $\mathrm{N}_{2}$. A similar reaction of $\mathrm{LM}(\mathrm{M}=\mathrm{Al}, \mathrm{Ga})$ with $\mathrm{N}_{3} \mathrm{~L}$ ' has been reported to afford LMNL' containing a M=N multiple bond. ${ }^{[191]}$ The latter ${ }^{1} \mathrm{H}$ NMR kinetic study also suggests the existence of $\mathbf{A}$ at low temperature. Compound $\mathbf{2 5}$ is formed as a result of a $[2+$ 2] cycloaddition of a phenyl ring of the Ar' substituent on nitrogen (route b, Scheme 20), while the formation of $\mathbf{2 6}$ might occur by an intramolecular $\mathrm{C}-\mathrm{H}$ activated addition involving the methyl group of the isopropyl substituent on the $\beta$-diketiminato ligand (route a).

Compounds $\mathbf{2 5}$ and $\mathbf{2 6}$ are thermally stable. They change with color at $\sim 320^{\circ} \mathrm{C}$ and finally melt at $381-382^{\circ} \mathrm{C}$. Both of them show the molecular ion $\left[M^{+}-1\right]$ at $\mathrm{m} / \mathrm{z} 855$. They have been characterized by spectroscopic, analytical and X-ray crystal measurements. 


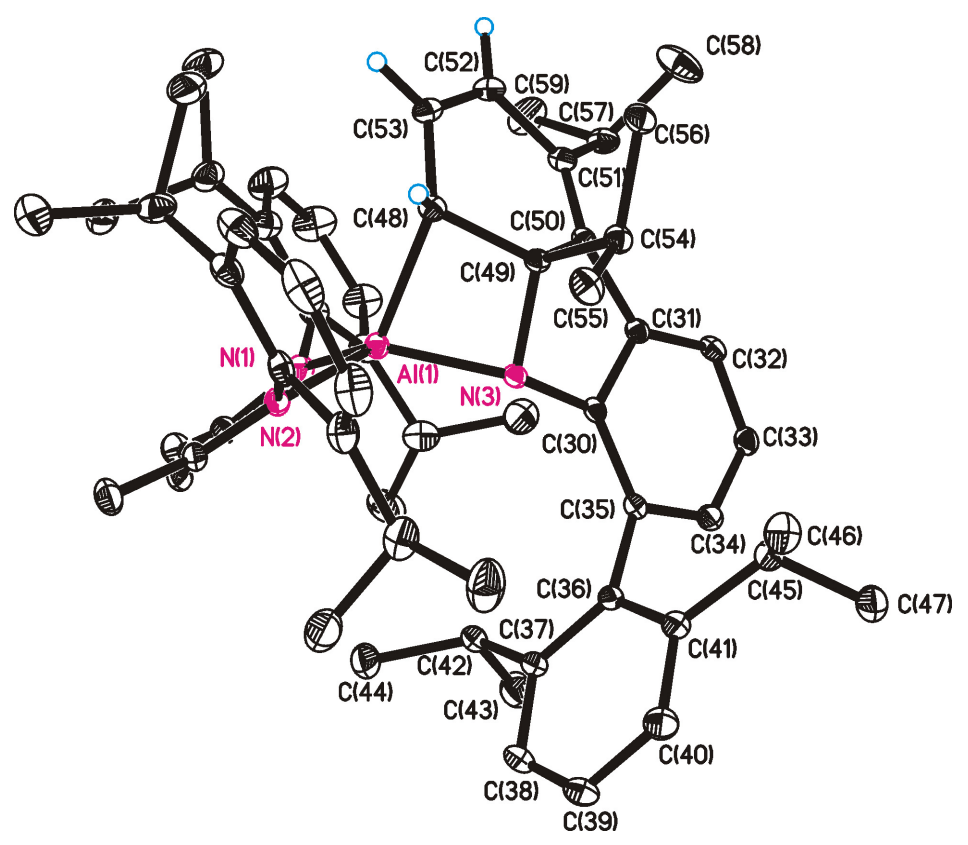

Figure 21. Molecular structure of 25. Selected bond lengths $(\AA)$ and angles $\left({ }^{\circ}\right)$ :Al(1)-N(1)

$$
\begin{aligned}
& 1.915(2), \mathrm{Al}(1)-\mathrm{N}(2) 1.926(2), \mathrm{Al}(1)-\mathrm{N}(3) 1.876(2), \mathrm{Al}(1)-\mathrm{C}(48) 1.998(3), \mathrm{C}(48)-\mathrm{C}(49) \\
& 1.536(4), \mathrm{C}(49)-\mathrm{C}(50) 1.520(4), \mathrm{C}(50)-\mathrm{C}(51) 1.348(4), \mathrm{C}(51)-\mathrm{C}(52) 1.469(4), \mathrm{C}(52)-\mathrm{C}(53) \\
& 1.336(4), \mathrm{C}(53)-\mathrm{C}(48) 1.475(4), \mathrm{N}(3)-\mathrm{C}(49) 1.537(3), \mathrm{N}(1)-\mathrm{Al}(1)-\mathrm{N}(2) 96.92(10), \mathrm{N}(3)- \\
& \mathrm{Al}(1)-\mathrm{N}(1) 127.76(10), \mathrm{N}(3)-\mathrm{Al}(1)-\mathrm{N}(2) 117.99(10), \mathrm{N}(3)-\mathrm{Al}(1)-\mathrm{C}(48) 78.53(10), \mathrm{Al}(1)- \\
& \mathrm{N}(3)-\mathrm{C}(30) 138.71(17) .
\end{aligned}
$$

The structure of $\mathbf{2 5}$ (Figure 21) exhibits a [2+2] cycloaddition product. The fourmembered $\mathrm{AlNC}_{2}$ ring is quasi-planar $(\Delta=0.0680 \AA)$ with $\mathrm{Al}-\mathrm{N}$ bond length $(1.876(2) \AA)$ longer than those in the $\mathrm{AlN}_{4}$ ring complex (1.851(2), 1.8152(15) $\left.\AA\right)^{[127]}$ and Al-C distance (1.998(3) $\AA$ ) similar to that in the $\mathrm{AlC}_{3} \mathrm{O}$ ring compound (1.9852(16) $\AA$ ). ${ }^{[155]}$ The phenyl ring involved in the $[2+2]$ cycloaddition becomes non-planar, where $C(50), C(51), C(52)$ and $\mathrm{C}(53)$ are in plane $(\Delta=0.0430 \AA), \mathrm{C}(48)$ and $\mathrm{C}(49)$ are away from this plane by 0.1813 and $0.2827 \AA$. The $\mathrm{C}-\mathrm{C}$ bond lengths for $\mathrm{C}(50)-\mathrm{C}(51)$ and $\mathrm{C}(52)-\mathrm{C}(53)$ are $1.348(4)$ and $1.336(4)$ $\AA$ and are typical of $\mathrm{C}=\mathrm{C}$ double bonds, ${ }^{[207]}$ while the remaining four $\mathrm{C}-\mathrm{C}$ distances are in the range (1.469(4)-1.536(4) $\AA$ ) and are indicative for $\mathrm{C}-\mathrm{C}$ single bonds. The structural features of this phenyl ring are in good agreement with the proton NMR spectrum. The resonances at $\delta$ 
$6.08(\mathrm{dd}), 5.41$ (d), and $2.43(\mathrm{~d}) \mathrm{ppm}$ are assigned to $\mathrm{H}_{\mathrm{e}}, \mathrm{H}_{\mathrm{f}}$ and $\mathrm{H}_{\mathrm{d}}$, respectively, reflecting the extent of (un)saturation at the carbons where these protons are attached.

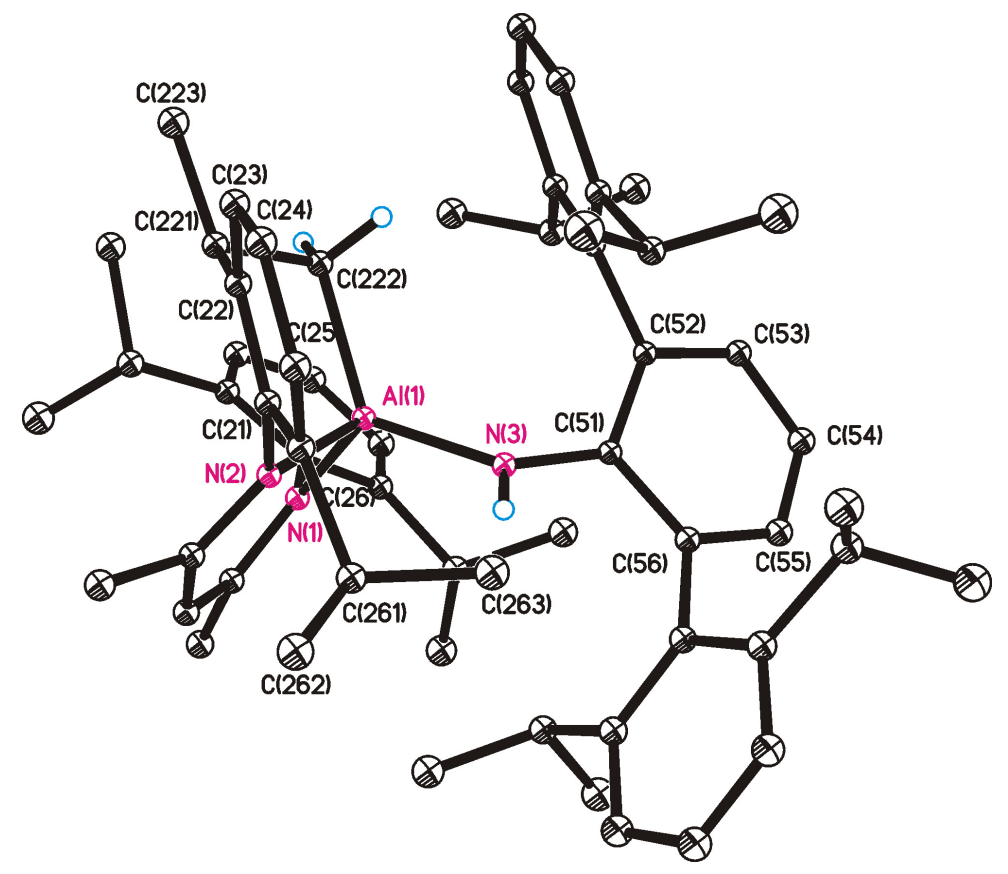

Figure 22. Molecular structure of 26. Selected bond lengths $(\AA)$ and angles $\left({ }^{\circ}\right)$ : Al(1)-N(1) 1.940(2), $\mathrm{Al}(1)-\mathrm{N}(2)$ 1.913(2), $\mathrm{Al}(1)-\mathrm{N}(3)$ 1.858(2), $\mathrm{Al}(1)-\mathrm{C}(222) 1.961(3), \mathrm{C}(222)-\mathrm{C}(221)$

$$
\begin{gathered}
1.556(3), \mathrm{N}(1)-\mathrm{Al}(1)-\mathrm{N}(2) 95.69(10), \mathrm{N}(3)-\mathrm{Al}(1)-\mathrm{N}(1) 115.78(9), \mathrm{N}(3)-\mathrm{Al}(1)-\mathrm{N}(2) \\
103.44(10), \mathrm{N}(3)-\mathrm{Al}(1)-\mathrm{C}(222) 122.34(10), \mathrm{Al}(1)-\mathrm{N}(3)-\mathrm{C}(51) 138.72(16)
\end{gathered}
$$

The X-ray crystal structure of $\mathbf{2 6}$ is shown in Figure 22. Compound $\mathbf{2 6}$ is monomeric and contains a tetra-coordinate $\mathrm{Al}(3 \mathrm{~N}, 1 \mathrm{C})$ center. The $\mathrm{Al}$ atom is involved as part of two fused six-membered rings $\left(\mathrm{AlN}_{2} \mathrm{C}_{3}\right.$ and $\left.\mathrm{AlNC}_{4}\right)$. The $\mathrm{Al}(1)-\mathrm{C}(222)(1.961(3) \AA)$ and $\mathrm{C}(222)-\mathrm{C}(221)$ (1.556(3) $\AA$ ) bond lengths are consistent with experimental values observed for $\mathrm{Al}-\mathrm{C}$ and $\mathrm{C}-$ $\mathrm{C}$ single bonds. This suggests the absence of strain within the $\mathrm{AlNC}_{4}$ ring formed as a result of Al-C ligation. The Al-NH(Ar') bond length (1.858(2) $\AA$ ) falls within the range (1.75-1.85 $\AA$ ) of terminal Al-N single bonds and a little shorter than that of $\mathrm{Al}(1)-\mathrm{N}(3)$ in $\mathbf{2 5}$. The $\mathrm{NH}$ and the $\mathrm{CH}_{2}$ protons $\left(\mathrm{H}_{\mathrm{a}}\right.$ and $\left.\mathrm{H}_{\mathrm{b}}\right)$ resonate at $\delta 3.41(\mathrm{~s}),-0.28(\mathrm{dd})$ and $-1.75(\mathrm{t})$, respectively. The assignment of these $\mathrm{Al}-\mathrm{CH}_{2}\left(\mathrm{H}_{\mathrm{a}}\right.$ and $\left.\mathrm{H}_{\mathrm{b}}\right)$ protons in the ${ }^{1} \mathrm{H}$ NMR spectrum of 26 is viewed in the following figure 23. The different dihedral angles between $\mathrm{H}(22 \mathrm{~B})-\mathrm{C}(222)-$ 
$\mathrm{C}(221)-\mathrm{H}(22 \mathrm{~A})$ and $\mathrm{H}(22 \mathrm{C})-\mathrm{C}(222)-\mathrm{C}(221)-\mathrm{H}(22 \mathrm{~A})$ give rise to different coupling constants as ${ }^{3} J_{\mathrm{H}(22 \mathrm{~B}) \mathrm{H}(22 \mathrm{~A})}=13.8 \mathrm{~Hz}$ and ${ }^{3} J_{\mathrm{H}(22 \mathrm{C}) \mathrm{H}(22 \mathrm{~A})}=3.0 \mathrm{~Hz}$ according to the Karplus formula of ${ }^{3} J_{\mathrm{HH}}$ $=\mathrm{A}-\mathrm{B} \cdot \cos \phi+\mathrm{C} \cdot \cos 2 \phi(\mathrm{A}=7, \mathrm{~B}=-1, \mathrm{C}=5),{ }^{[208]}$ While $^{2} J_{\mathrm{H}(22 \mathrm{~B}) \mathrm{H}(22 \mathrm{C})}=-13.8 \mathrm{~Hz}$, therefore, the resonances at $\delta-0.28(\mathrm{dd})$ and $-1.75(\mathrm{t})$ are assigned to $\mathrm{H}(22 \mathrm{~B})\left(\mathrm{H}_{\mathrm{b}}\right)$ and $\mathrm{H}(22 \mathrm{C})\left(\mathrm{H}_{\mathrm{a}}\right)$, respectively. The characteristic absorption at $3298 \mathrm{~cm}^{-1}$ is assignable to $v_{\mathrm{NH}}$ in the IR spectrum of $\mathbf{2 6 .}$

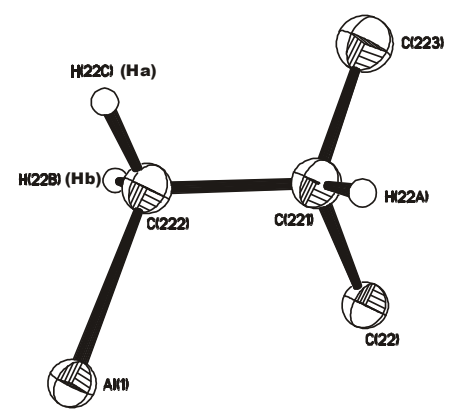

Figure 23

Now we gain further insight into the reaction process between $\mathrm{LAl}$ and $\mathrm{N}_{3} \mathrm{Ar}$ ' carried out by a variable-temperature ${ }^{1} \mathrm{H}$ NMR study (Figure 24). To a mixture of equivalent LAl and $\mathrm{N}_{3}$ Ar' at $-78{ }^{\circ} \mathrm{C}$, pre-cooled $\mathrm{D}_{8}$-toluene was added. At $-70{ }^{\circ} \mathrm{C}$, the proton NMR spectrum only presents the features indicated for those of $\mathrm{N}_{3} \mathrm{Ar}$ '. This shows the only dissolving of $\mathrm{N}_{3} \mathrm{Ar}$ ' in $\mathrm{D}_{8}$-toluene at this temperature. From -50 to $-10{ }^{\circ} \mathrm{C}$, the occurrence of a singlet at $\delta 5.05-4.60$ ppm assigned for that of $\gamma-\mathrm{CH}$ proton in $\mathrm{L}$ indicates the starting and proceeding of this reaction, which initiate the dissolving of LAl species. The changes of the chemical shift of this singlet in this area are temperature-dependent. The sample was kept at $50{ }^{\circ} \mathrm{C}$ for $1 \mathrm{~h}$ and the corresponding proton NMR spectrum showed that there were no remarkable changes of resonances compared to those in the previous one at $50{ }^{\circ} \mathrm{C}$. While for $24 \mathrm{~h}$ the measurement on the sample showed the great changes of resonances in the spectrum.

Therefore, the $\gamma-\mathrm{CH}$ of the starting material LAl resonates at $\sim 5.10 \mathrm{ppm}$ (the low temperature ${ }^{1} \mathrm{H}$ NMR spectrum of the starting material LAl was measured as a reference. The resonances of $\gamma-\mathrm{CH}$ at $\delta 5.11,5.13,5.14$, and $5.15 \mathrm{ppm}$ correspond at $-50,-30,-10,25^{\circ} \mathrm{C}$ ), 
its change is a good indicator for the progress of the reaction. Thus in $\mathrm{I}$, from -50 to $-10^{\circ} \mathrm{C}$, the occurrence of one singlet may indicate the formation of A. From -10 to $50^{\circ} \mathrm{C}$, this singlet was gradually transformed into two other singlets, suggesting the further reaction of $\mathbf{A}$ and the
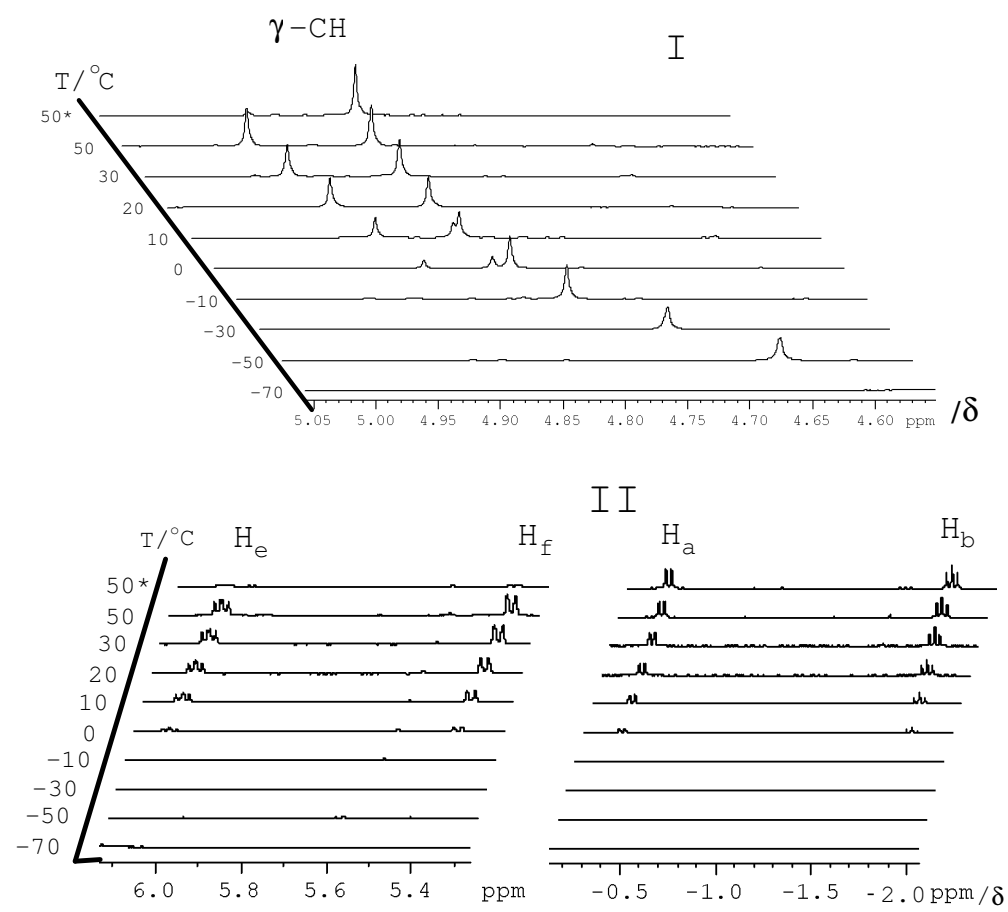

Figure 24. Variable-temperature ${ }^{1} \mathrm{H}$ NMR kinetic studies of the reaction of LAl with $\mathrm{N}_{3} \mathrm{Ar}$ ' in $\left[\mathrm{D}_{8}\right]$ toluene. (I) records the resonances of $\gamma-\mathrm{CH}$ proton $(\delta 5.05-4.60 \mathrm{ppm})$ which correlate with changes of LAl moiety and (II) shows those of $\mathbf{2 5}\left(\mathrm{H}_{\mathrm{f}}\right.$ and $\left.\mathrm{H}_{\mathrm{g}}, \delta 6.20-5.20 \mathrm{ppm}\right)$ and $\mathbf{2 6}$ $\left(\mathrm{H}_{\mathrm{a}}\right.$ and $\left.\mathrm{H}_{\mathrm{b}}, \delta 0.00--2.00 \mathrm{ppm}\right) .50^{*}$ means the available ${ }^{1} \mathrm{H}$ NMR data by keeping the sample at $50{ }^{\circ} \mathrm{C}$ for $24 \mathrm{~h}$.

concomitant formation of compounds $\mathbf{2 5}$ and 26. This is further evidenced by the corresponding presence of the characteristic proton resonances in II indicative for $\mathbf{2 5}$ and $\mathbf{2 6}$, respectively. The almost same integral intensity of $\mathbf{2 5}$ and $\mathbf{2 6}$ shows the equiponderance of the intramolecular addition of $\mathbf{A}$ via routes a and b. Keeping this reaction at $50{ }^{\circ} \mathrm{C}$ for $24 \mathrm{~h}$, the final spectrum shows the disappearance of the characteristic resonances for $\mathbf{2 5}$ and the growing in of those for $\mathbf{2 6}$. This experiment confirms the result of recrystallization of $\mathbf{2 5}$ from a hot solution to yield $\mathbf{2 6 .}$ 
The strained structure of $\mathbf{2 5}$ (torsional $\mathrm{AlC}_{2} \mathrm{~N}$ and $\mathrm{C}_{6}$ rings) compared to that of $\mathbf{2 6}$ may energetically favor this thermal rearrangement. While the deliberate ${ }^{1} \mathrm{H}$ NMR kinetic studies of this reaction unambiguously reveal the thermal stability of these three isomers in the order of $\mathrm{A}<\mathbf{2 5}<\mathbf{2 6}$.

At last, an unprecedented reaction, which occurs by an intramolecular addition to an Al-N multiple bonded species LAlNAr' and furthermore by rearrangement of $\mathbf{2 5}$ to $\mathbf{2 6}$ without changing the monomeric nature of the products, has been shown. Presently we are involved in the low temperature synthesis of $\mathbf{A}$ and especially its X-ray structural analysis. 


\section{Summary and Outlook}

In this thesis, the sterically bulky diamido L' and $\beta$-diketiminato L ligands are employed as supporting moieties in aluminum compounds. Compounds 1-26 have been isolated and characterized (Schemes 21, 22, and 23). The experimental results demonstrate that a number of functional reactions involving an $\mathrm{Al}(\mathrm{I})$ or $\mathrm{Al}(\mathrm{III})$ center are realized exhibiting diverse reaction types and rich organoaluminum chemistry.

Moreover, organoaluminum chemistry has emerged as a more and more relatively mature field: new syntheses are being developed, much of its basic chemistry is being explored, and many of the prevailing structural types are in delineation. The motivating force for such fundamental studies has been the widespread industrial importance of these organometallic compounds in stoichiometric and catalytic processes. 


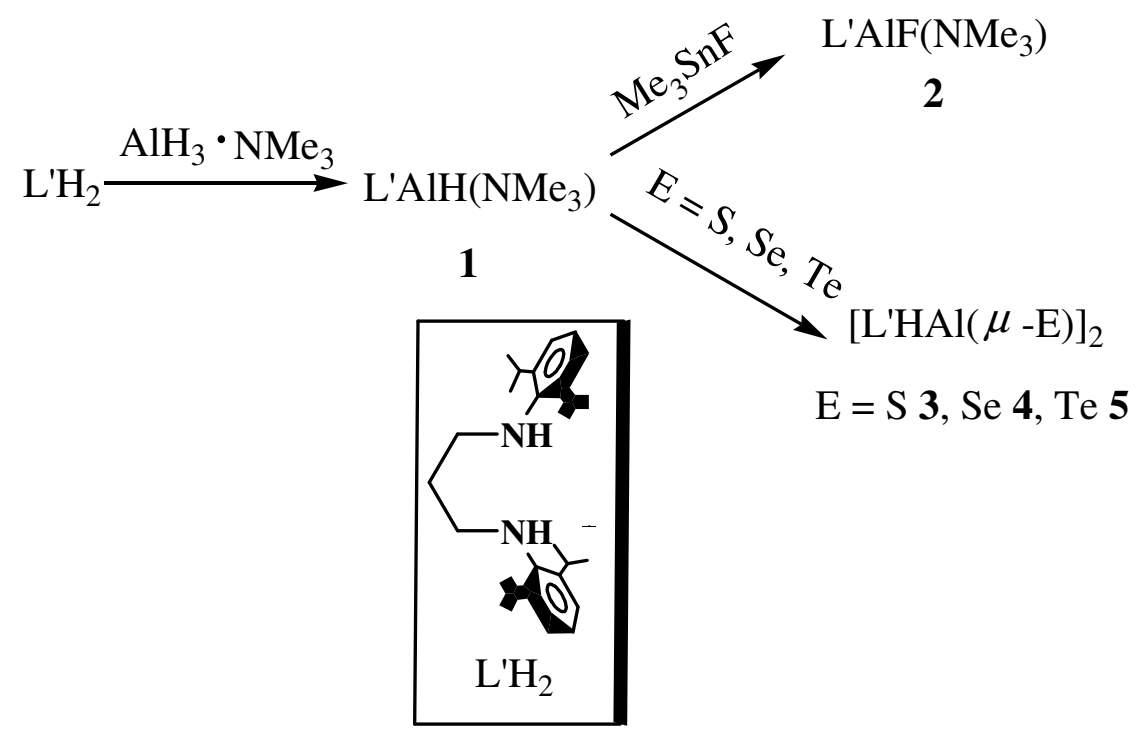

Scheme 21

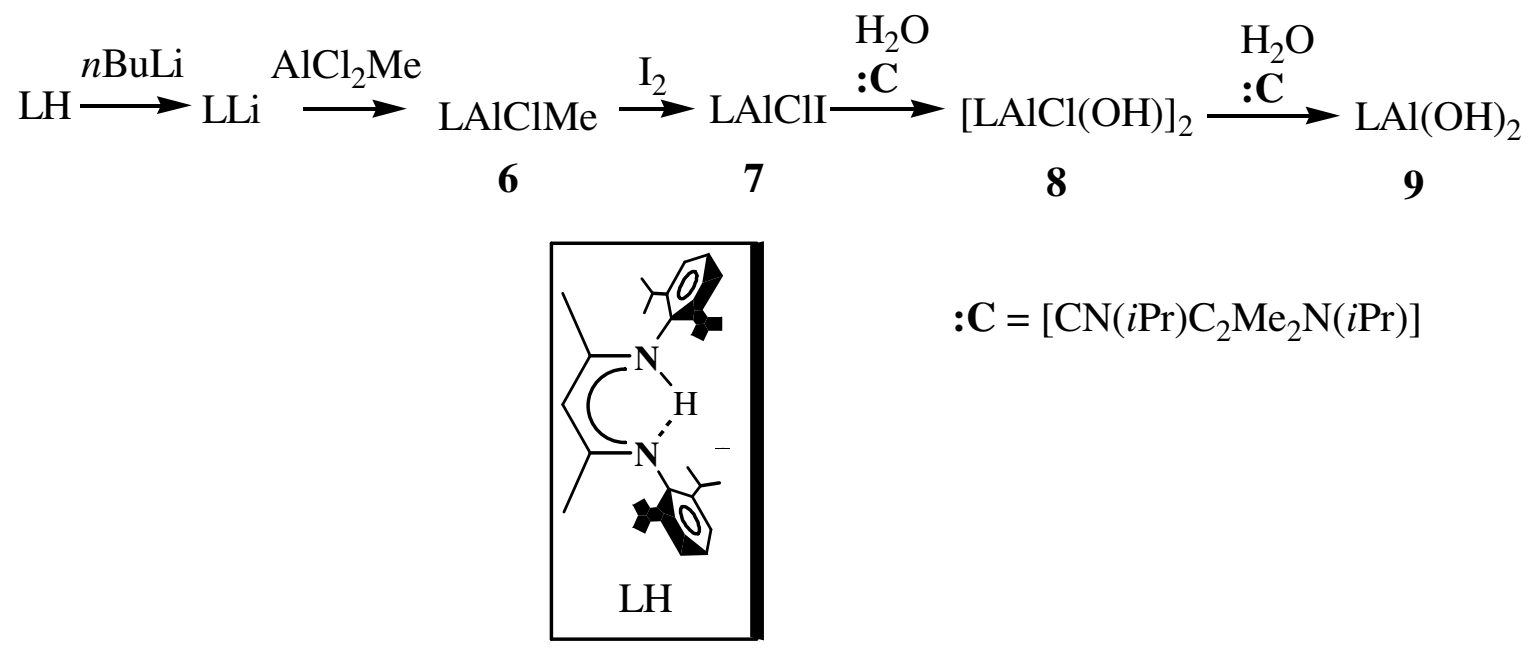

Scheme 22 


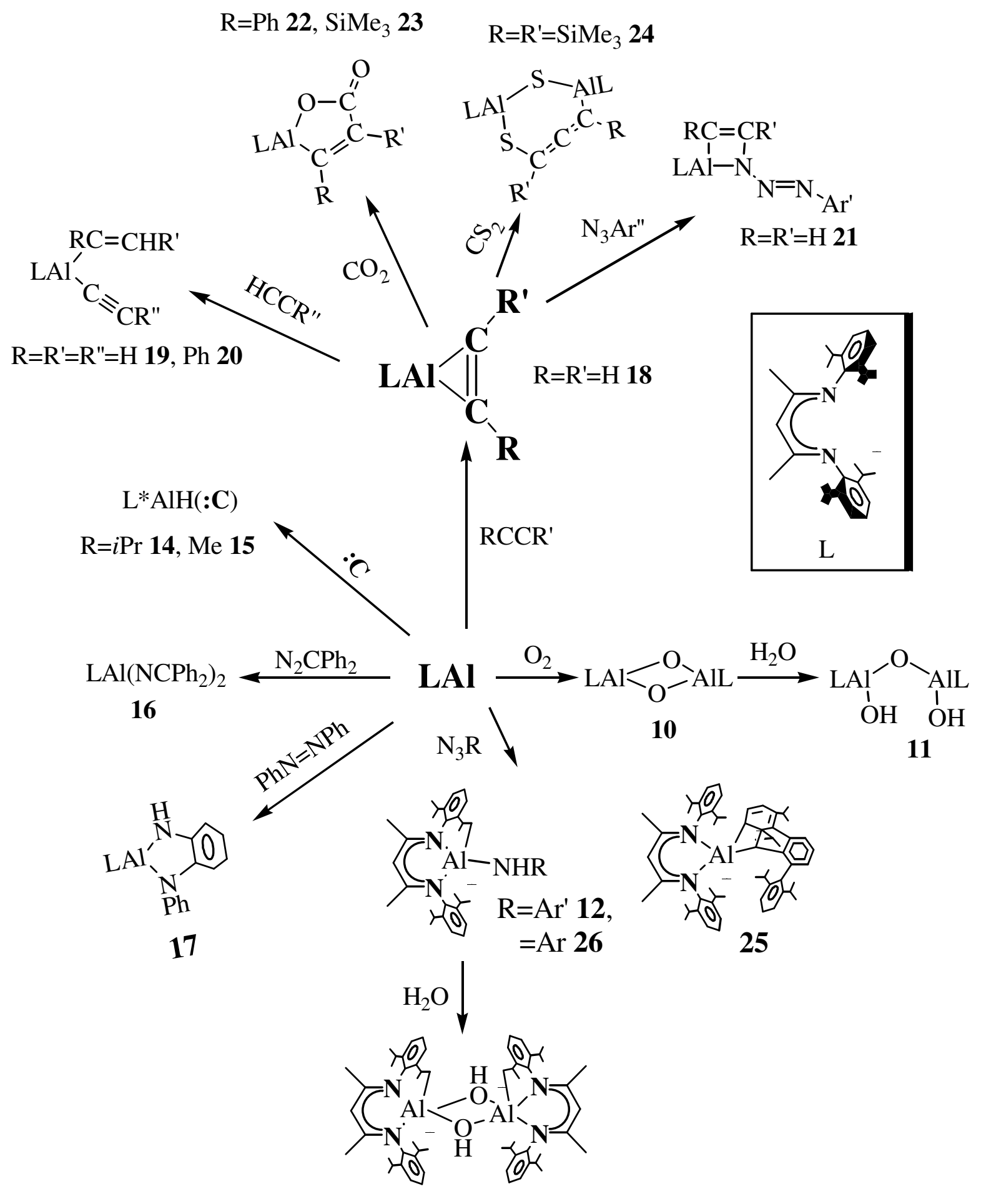

13

Scheme 23 


\section{Experimental Sections}

\subsection{General Procedures}

All manipulations were carried out under a dry nitrogen atmosphere using Schlenk techniques or inside a Mbraun MB 150-GI glovebox filled with nitrogen, where the $\mathrm{O}_{2}$ and $\mathrm{H}_{2} \mathrm{O}$ level were strictly maintained below $1 \mathrm{ppm}$. All solvents were distilled from $\mathrm{Na} /$ benzophenone ketyl prior to use.

\subsection{Physical measurements.}

The melting points of all compounds described in this thesis were measured in sealed glass tubes on a Bühler SPA-1 apparatus and are not corrected.

Mass spectra were obtained on a Finnigan MAT 8230 or a Varian MAT CH5 instrument by EI-, FI-, and FAB-MS techniques.

IR spectra were recorded on a Bio-Rad Digilab FTS-7 spectrometer as Nujol mulls on KBr plates. Intensities were abbreviated as follows: s (strong), m (middle), w (weak). In most cases only the characteristic absorptions are listed.

${ }^{1} \mathrm{H},{ }^{13} \mathrm{C},{ }^{19} \mathrm{~F},{ }^{27} \mathrm{Al},{ }^{29} \mathrm{Si}$, and ${ }^{77} \mathrm{Se}$ NMR spectra were recorded on a Bruker-Avance-500, Avance-200, MSL-400, AM-250, and AM-200 spectrometers. The chemical shifts are reported in ppm (positive shifts being downfield) with reference to external standards $\left(\mathrm{SiMe}_{4}\right.$ for ${ }^{1} \mathrm{H},{ }^{13} \mathrm{C}$, and ${ }^{29} \mathrm{Si}, \mathrm{CFCl}_{3}$ for ${ }^{19} \mathrm{~F}, \mathrm{AlCl}_{3}$ for ${ }^{27} \mathrm{Al}$, and $\mathrm{Me}_{2} \mathrm{Se}$ for ${ }^{77} \mathrm{Se}$ nuclei). If not otherwise stated, the operation temperature was at ca. $298 \mathrm{~K}$. The symbols ( $\mathrm{s}=$ singlet, $\mathrm{d}=$ doublet, $\mathrm{t}=$ triplet, $\mathrm{q}=$ quartet, sept $=$ septet, $\mathrm{dd}=$ double doublet, $\mathrm{m}=$ mutiplet ) are $\mathrm{used}$.

Elemental analyses were performed by the Analytisches Labor des Instituts für Anorganische Chemie der Universität Göttingen.

X-ray structure determinations and refinements. The crystallographic data for $1,2,4,16$, and 17 were collected on a Stoe AED2, for 7, 8, 14, 18, 19, 20, 21, 25, and 26 on IPDS II- 
array detector system with four-circle instrument using graphite-monochromated $\mathrm{Mo} / \mathrm{K} \alpha$ radiation $(\lambda=0.71073 \AA)$, and for $\mathbf{1 0}, \mathbf{1 2}, \mathbf{1 3}, \mathbf{2 2}, \mathbf{2 3}$, and 24 on a bruker three-circle diffractmeter equipped with a SMART $6000 \mathrm{CCD}$ detector using monochromated $\mathrm{Cu}-\mathrm{K} \alpha$ radiation $\left(\lambda=1.54178 \AA\right.$ ). All structures were solved by direct methods (SHELXS-97) ${ }^{[212]}$ and refined with all data by full-least-squares against $F^{2}{ }^{[213]}$ The non-hydrogen atoms were located by difference Fourier synthesis and refined anisotropically. The hydrogen atoms were included in geometrically idealized positions with the $U$ iso tied to that of the parent atoms and were refined with the riding model, or by difference Fourier synthesis and refined isotropically. Crystal data, data collection details, structural solution and refinement procedures for all the compounds are summarized in the tables.

\subsection{Starting materials}

Commercially available chemicals were purchased from Fluka or Aldrich and used as received. The gas phase chemicals such as $\mathrm{O}_{2}, \mathrm{HCCH}, \mathrm{CO}_{2}, \mathrm{CO}, \mathrm{H}_{2} \mathrm{CCH}_{2}$ are predried by $\mathrm{P}_{4} \mathrm{O}_{10}$ perior to use. The other compounds used in the syntheses were prepared according to published references: $\mathrm{L}^{\prime}\left(\mathrm{L}^{\prime}=\operatorname{ArNH}\left(\mathrm{CH}_{2}\right)_{3} \mathrm{HNAr}, \mathrm{Ar}=2,6-i \mathrm{Pr}_{2} \mathrm{C}_{6} \mathrm{H}_{3}\right),{ }^{[31]} \mathrm{AlH}_{3} \cdot \mathrm{NMe}_{3},{ }^{[209]}$ $\mathrm{Me}_{3} \mathrm{SnF},{ }^{[210]} \quad\left[\mathrm{ArN}\left(\mathrm{CH}_{2}\right)_{3} \mathrm{NAr}\right] \mathrm{AlMe},{ }^{[35]} \mathrm{L} \quad\left(\mathrm{L} \quad=\mathrm{HC}[(\mathrm{CMe})(\mathrm{NAr})]_{2}\right),{ }^{[81]} \mathrm{LAlI}_{2},{ }^{[95]}$ $\left[\mathrm{CN}(\mathrm{R}) \mathrm{C}_{2} \mathrm{Me}_{2} \mathrm{~N}(\mathrm{R})\right](: \mathrm{C}, \mathrm{R}=\mathrm{Me}, i \mathrm{Pr}),{ }^{[132]} \mathrm{N}_{2} \mathrm{CPh}_{2},{ }^{[133]} \mathrm{N}_{3} \mathrm{R}\left(\mathrm{R}=\mathrm{Ar}, \mathrm{Ar}{ }^{\prime}\right) .{ }^{[211]}$ 


\subsection{Syntheses}

\section{$\left[\operatorname{ArN}\left(\mathrm{CH}_{2}\right)_{3} \mathrm{NAr}\right] \mathrm{AlH}\left(\mathrm{NMe}_{3}\right)(1)$}

A solution of diamine $\operatorname{ArNH}\left(\mathrm{CH}_{2}\right)_{3} \mathrm{HNAr}(4.03 \mathrm{~g}, 10.24 \mathrm{mmol})\left(\mathrm{Ar}=2,6-i \mathrm{Pr}_{2} \mathrm{C}_{6} \mathrm{H}_{3}\right)$ in toluene $(20 \mathrm{~mL})$ was added to a solution of $\mathrm{AlH}_{3} \cdot \mathrm{NMe}_{3}(1.18 \mathrm{~g}, 13.24 \mathrm{mmol})$ in toluene (30 $\mathrm{mL}$ ). While stirring, gas evolution was observed. The mixture was slowly heated to $80{ }^{\circ} \mathrm{C}$ and stirred for 5 h. All volatiles were removed in vacuum and the residue was extracted with $n$ hexane. Filtered through Celite, the extract was evaporated to dryness to afford $\left[\mathrm{ArN}\left(\mathrm{CH}_{2}\right)_{3} \mathrm{NAr}\right] \mathrm{AlH}\left(\mathrm{NMe}_{3}\right)$ as a white solid. X-ray quality crystals were grown from $n$ hexane.

Yield: 4.41 g, $90 \%$. M.p. $196-197^{\circ} \mathrm{C}$.

${ }^{1} \mathrm{H}$ NMR (200.13 MHz, $\left.300 \mathrm{~K}, \mathrm{C}_{6} \mathrm{D}_{6}, \mathrm{ppm}\right): \delta=1.22,1.37,1.47,1.66$ (d, 24H, CHMe $), 1.66$ (s, 9H, $\left.\mathrm{NMe} e_{3}\right), 2.10,3.00$ (m, 2H, $\left.\mathrm{NCH}_{2} \mathrm{CH}_{2}\right), 3.25-3.45$ (m, 4H, $\left.\mathrm{NCH}_{2}\right), 3.63,4.25$ (sept, 4H, $\left.\mathrm{C} H \mathrm{Me}_{2}\right), 7.10-7.16$ (m, 6H, Ar-H).

$\mathrm{MS}(\mathrm{EI}): m / z=420\left[M^{+}-\mathrm{NMe}_{3}\right]$.

IR (KBr plate, Nujol mull, $\left.\mathrm{cm}^{-1}\right): \widetilde{v}=1799(\mathrm{sh}, \mathrm{Al}-\mathrm{H})$.

$\mathrm{C}_{33} \mathrm{H}_{57} \mathrm{AlN}_{3}$ (522.02) (1·1/2n-hexane): calcd. C 75.93, H 11.00, N 8.05; found C 75.44, H $10.64, \mathrm{~N} 8.26$.

\section{$\left[\operatorname{ArN}\left(\mathrm{CH}_{2}\right)_{3} \mathbf{N A r}\right] \mathrm{AlF}\left(\mathrm{NMe}_{3}\right)(2)$}

Method 1: A suspension of 1 (1.44 g, $3 \mathrm{mmol})$ and $\mathrm{Me}_{3} \mathrm{SnF}(0.55 \mathrm{~g}, 3 \mathrm{mmol})$ in toluene (30 $\mathrm{mL}$ ) was heated to $80^{\circ} \mathrm{C}$ and stirred for $12 \mathrm{~h}$. After filtration, the filtrate was concentrated to ca. $10 \mathrm{~mL}$ in vacuum and kept at $4{ }^{\circ} \mathrm{C}$ for $48 \mathrm{~h}$ to afford colorless block-shaped crystals of 2 . Yield: 1.20 g, $80 \%$. M.p. $220-222^{\circ} \mathrm{C}$.

${ }^{1} \mathrm{H}$ NMR (200.13 MHz, $\left.300 \mathrm{~K}, \mathrm{C}_{6} \mathrm{D}_{6}, \mathrm{ppm}\right): \delta=1.22,1.35,1.47,1.71(\mathrm{~d}, 24 \mathrm{H}, \mathrm{CHMe} 2), 1.75$ (s, 9H, NMe 3 ), 2.00, 3.00 (m, 2H, $\mathrm{NCH}_{2} \mathrm{CH}_{2}$ ), 3.27, 3.40 (m, 4H, $\mathrm{NCH}_{2}$ ), 3.64, 4.29 (sept, 4H, $\left.\mathrm{C} H \mathrm{Me}_{2}\right), 7.10-7.32(\mathrm{~m}, 6 \mathrm{H}, \mathrm{Ar}-H)$.

${ }^{19} \mathrm{~F}$ NMR (188.29 MHz, $\left.300 \mathrm{~K}, \mathrm{C}_{6} \mathrm{D}_{6}, \mathrm{ppm}\right): \delta=-12.4$ (adjusted value, -175.4).

MS (EI): $m / z=497\left[M^{+}\right], 438\left[M^{+}-\mathrm{NMe}_{3}\right]$.

$\mathrm{C}_{30} \mathrm{H}_{49} \mathrm{AlFN}_{3}$ (497.72): calcd. C 72.40, H 9.92, N 8.44; found: C 72.31, H 9.71, N 8.28.

Method 2: A suspension of $1(1.44 \mathrm{~g}, 3 \mathrm{mmol})$ and $\mathrm{Me}_{3} \mathrm{SnF}(0.55 \mathrm{~g}, 3 \mathrm{mmol})$ in toluene (30 $\mathrm{mL}$ ) was stirred for $4 \mathrm{~d}$ at room temperature till $\mathrm{Me}_{3} \mathrm{SnF}$ was almost consumed. After filtration, the filtrate was concentrated to ca. $10 \mathrm{~mL}$ in vacuum and kept at $4{ }^{\circ} \mathrm{C}$ for a week to 
afford colorless crystals. All spectroscopy confirmed the same compound as that obtained from method 1.

\section{$\left\{\left[\operatorname{ArNH}\left(\mathrm{CH}_{2}\right)_{3} \mathrm{NAr}\right] \mathrm{Al}(\mu-\mathrm{S})\right\}_{2}(3)$}

A suspension of $1(1.48 \mathrm{~g}, 3 \mathrm{mmol})$ and elemental $\mathrm{S}(0.096 \mathrm{~g}, 3 \mathrm{mmol})$ in toluene $(30 \mathrm{~mL})$ was heated to $80{ }^{\circ} \mathrm{C}$ and stirred for $12 \mathrm{~h}$. After filtration, the orange-red filtrate was concentrated to ca. $10 \mathrm{~mL}$ and kept at $4{ }^{\circ} \mathrm{C}$ for $48 \mathrm{~h}$ to afford light yellow crystals of 3.toluene.

Yield: 1.00 g, $67 \%$. M.p. $278-279^{\circ} \mathrm{C}\left(>250^{\circ} \mathrm{C}\right.$, decompose).

${ }^{1} \mathrm{H}$ NMR (200.13 MHz, $\left.300 \mathrm{~K}, \mathrm{C}_{6} \mathrm{D}_{6}, \mathrm{ppm}\right): \delta=1.17,1.22$ (d, 48H, CHMe $), 1.36$ (s, 2H, $\mathrm{NH}), 1.78\left(\mathrm{~m}, 4 \mathrm{H}, \mathrm{NCH}_{2} \mathrm{CH}_{2}\right), 2.1(\mathrm{~s}, 3 \mathrm{H}, \mathrm{MePh}), 3.00\left(\mathrm{t}, 8 \mathrm{H}, \mathrm{NCH} \mathrm{H}_{2}\right), 3.38$ (sept, 8H, $\mathrm{CHMe}_{2}$ ), 6.96-7.04 (m, 5H, MePh), 7.02-7.10 (m, 12H, Ar-H).

MS (EI): $m / z=904\left[M^{+}\right]$.

IR (KBr plate, Nujol mull, $\left.\mathrm{cm}^{-1}\right): \tilde{v}=3190(\mathrm{NH})$.

$\mathrm{C}_{61} \mathrm{H}_{90} \mathrm{Al}_{2} \mathrm{~N}_{4} \mathrm{~S}_{2}$ (996.8) (3.toluene): calcd. C 73.50, H 9.10, N 5.62; found: C 73.25, H 8.90, N 5.07 .

\section{$\left\{\left[\operatorname{ArNH}\left(\mathrm{CH}_{2}\right)_{3} \mathrm{NAr}\right] \mathrm{Al}(\mu-\mathrm{Se})\right\}_{2}(4)$}

A suspension of $1(1.44 \mathrm{~g}, 3 \mathrm{mmol})$ and elemental gray Se powder $(0.24 \mathrm{~g}, 3 \mathrm{mmol})$ in toluene $(30 \mathrm{~mL})$ was refluxed for $12 \mathrm{~h}$ and almost all the selenium was consumed. In the course of hot filtration, the yellowish crystals were grown from the orange filtrate, which were collected by filtration. $(0.10 \mathrm{~g})$. The mother liquor was concentrated to ca. $10 \mathrm{~mL}$ and kept at $4{ }^{\circ} \mathrm{C}$ for $24 \mathrm{~h}$ to afford another crop of yellowish crystals of $\mathbf{4} \cdot 2$ toluene $(1.00 \mathrm{~g})$.

Total yield: $1.10 \mathrm{~g}(62 \%)$. M.p. $291^{\circ} \mathrm{C}\left(>259^{\circ} \mathrm{C}\right.$, decompose).

${ }^{1} \mathrm{H}$ NMR (200.13 MHz, $\left.300 \mathrm{~K}, \mathrm{C}_{6} \mathrm{D}_{6}, \mathrm{ppm}\right): \delta=1.17,1.22\left(\mathrm{~d}, 48 \mathrm{H}, \mathrm{CH} M e_{2}\right), 1.36(\mathrm{~s}, 2 \mathrm{H}$, $\mathrm{NH}), 1.78\left(\mathrm{~m}, 4 \mathrm{H}, \mathrm{NCH}_{2} \mathrm{CH}_{2}\right), 2.1(\mathrm{~s}, 6 \mathrm{H}, \mathrm{MePh}), 3.00$ (t, 8H, $\left.\mathrm{NCH}_{2}\right), 3.38$ (sept, 8H, $\mathrm{CHMe}_{2}$ ), 6.94-7.04 (m, 10H, MePh), 7.02-7.10 (m, 12H, Ar-H).

${ }^{77} \mathrm{Se} \mathrm{NMR}\left(500 \mathrm{MHz}, 300 \mathrm{~K}, \mathrm{C}_{6} \mathrm{D}_{6}, \mathrm{CDCl}_{3}\right.$, or $\mathrm{C}_{7} \mathrm{D}_{8}$, ppm): no resonances were observed. $\operatorname{MS}(\mathrm{EI}): m / z=998\left[M^{+}\right]$.

IR (KBr plate, Nujol mull, $\left.\mathrm{cm}^{-1}\right): \tilde{v}=3187(\mathrm{NH})$.

$\mathrm{C}_{68} \mathrm{H}_{98} \mathrm{Al}_{2} \mathrm{~N}_{4} \mathrm{Se}_{2}$ (1182.9) (4·2toluene): calcd. C 69.04, $\mathrm{H}$ 8.35, N 4.74; found: $\mathrm{C} \mathrm{68.79,} \mathrm{H}$ $8.22, \mathrm{~N} 4.63$. 
A suspension of 1 (1.44 g, $3 \mathrm{mmol})$ and elemental Te powder $(0.39 \mathrm{~g}, 3 \mathrm{mmol})$ in toluene (40 $\mathrm{mL}$ ) was refluxed for $5 \mathrm{~d}$ and there still remained small amounts of unreacted Te powder. After filtration, the green-yellow filtrate was concentrated to ca. $10 \mathrm{~mL}$ and to it $n$-hexane (5 $\mathrm{mL}$ ) was added. The solution was kept at $4{ }^{\circ} \mathrm{C}$ for $24 \mathrm{~h}$ to afford green-yellow crystals of 5.toluene.

Yield: 0.85 g, $48 \%$. M.p. $320^{\circ} \mathrm{C}$ (decompose).

${ }^{1} \mathrm{H}$ NMR (200.13 MHz, $\left.300 \mathrm{~K}, \mathrm{C}_{6} \mathrm{D}_{6}, \mathrm{ppm}\right): \delta=1.17,1.22$ (d, 48H, CHMe $), 1.35$ (s, 2H, $\mathrm{NH}), 1.75\left(\mathrm{~m}, 4 \mathrm{H}, \mathrm{NCH}_{2} \mathrm{CH}_{2}\right), 2.1$ (s, 3H, MePh), 3.00 (t, 8H, $\left.\mathrm{NCH}_{2}\right), 3.37$ (sept, 8H, $\mathrm{CHMe}_{2}$ ), 6.94-7.04 (m, 5H, MePh), 7.02-7.10 (m, 12H, Ar-H).

$\operatorname{MS}(\mathrm{EI}): m / z=1096\left[M^{+}\right]$.

IR (KBr plate, Nujol mull, $\left.\mathrm{cm}^{-1}\right): \widetilde{v}=3185(\mathrm{NH})$.

$\mathrm{C}_{61} \mathrm{H}_{90} \mathrm{Al}_{2} \mathrm{~N}_{4} \mathrm{Te}_{2}$ (1188.1) (5.toluene): calcd. C 61.67, H 7.63, N 4.71; found: C 61.72, $\mathrm{H}$ 7.61, N 4.76 .

\section{LAICIMe (6)}

To a toluene solution $(80 \mathrm{~mL})$ of $\mathrm{LH}(8.36 \mathrm{~g}, 20 \mathrm{mmol})$ at $0{ }^{\circ} \mathrm{C} n$-BuLi $(2 \mathrm{M}, 10 \mathrm{~mL}, 20$ mmol) was added dropwise. The mixture was stirred and allowed to warm to room temperature. After additional stirring for $12 \mathrm{~h}$, the solution was cooled to $-78{ }^{\circ} \mathrm{C}$ and $\mathrm{AlCl}_{2} \mathrm{Me}$ (1 M, $20 \mathrm{~mL}, 20 \mathrm{mmol}$ ) was added. The resulting suspension was allowed to warm to room temperature and stirred for $12 \mathrm{~h}$. After workup, the insoluble $\mathrm{LiCl}$ was removed by filtration and the filtrate was dried in vacuo and washed with $n$-hexane to yield crystalline solid of 6. Yield: 9.1 g, $92 \%$. M.p. $191-192{ }^{\circ} \mathrm{C}$.

${ }^{1} \mathrm{H}$ NMR (300.13 MHz, $\left.298 \mathrm{~K}, \mathrm{C}_{6} \mathrm{D}_{6}, \mathrm{ppm}\right): \delta=-0.64(\mathrm{~s}, 3 \mathrm{H}, \mathrm{Al}-\mathrm{Me}), 1.00\left(\mathrm{~d}, 2 \times 3 \mathrm{H},{ }^{3} J_{\mathrm{HH}}\right.$ $\left.=6.8 \mathrm{~Hz}, \mathrm{CH}\left(\mathrm{CH}_{3}\right)_{2}\right), 1.19\left(\mathrm{~d}, 2 \times 3 \mathrm{H},{ }^{3} J_{\mathrm{HH}}=6.8 \mathrm{~Hz}, \mathrm{CH}\left(\mathrm{CH}_{3}\right)_{2}\right), 1.28\left(\mathrm{~d}, 2 \times 3 \mathrm{H},{ }^{3} J_{\mathrm{HH}}=6.8\right.$ $\left.\mathrm{Hz}, \mathrm{CH}\left(\mathrm{CH}_{3}\right)_{2}\right), 1.46\left(\mathrm{~d}, 2 \times 3 \mathrm{H},{ }^{3} \mathrm{~J}_{\mathrm{HH}}=6.8 \mathrm{~Hz}, \mathrm{CH}\left(\mathrm{CH}_{3}\right)_{2}\right), 1.54(\mathrm{~s}, 2 \times 3 \mathrm{H}, \beta-M e), 3.21$ (sept, 2 × $\left.1 \mathrm{H},{ }^{3} J_{\mathrm{HH}}=6.8 \mathrm{~Hz}, \mathrm{CH}\left(\mathrm{CH}_{3}\right)_{2}\right), 3.77$ (sept, $\left.2 \times 1 \mathrm{H},{ }^{3} J_{\mathrm{HH}}=6.8 \mathrm{~Hz}, \mathrm{CH}\left(\mathrm{CH}_{3}\right)_{2}\right), 4.98$ (s, $1 \mathrm{H}, \gamma-\mathrm{CH}), 7.00-7.10(\mathrm{~m}, 6 \mathrm{H}, \mathrm{Ar}-H)$.

MS (EI): $m / z(\%): 494.3\left(3,\left[M^{+}\right]\right), 479.3\left(100,\left[M^{+}-\mathrm{Me}\right]\right)$.

$\mathrm{C}_{30} \mathrm{H}_{44} \mathrm{AlClN}_{2}$ (495.13): calcd. C 72.77, H 8.96, N 5.66; Found: C 72.32, H 8.74, N 5.71.

\section{LAICII (7)}

A toluene solution $(80 \mathrm{~mL})$ of $\mathbf{6}(7.43 \mathrm{~g}, 15 \mathrm{mmol})$ and $\mathrm{I}_{2}(3.81 \mathrm{~g}, 15 \mathrm{mmol})$ was stirred for 5 d. The solution was concentrated (ca $20 \mathrm{~mL}$ ) and kept at $4{ }^{\circ} \mathrm{C}$ for $24 \mathrm{~h}$. The very light yellow crystals of 7 were formed and collected $(5.5 \mathrm{~g})$. The mother liquor was concentrated (ca $5 \mathrm{~mL}$ 
) to afford a second crop of 7 (1.7 g).

Total yield: $7.2 \mathrm{~g}(79 \%)$. M.p. $200-203{ }^{\circ} \mathrm{C}$.

${ }^{1} \mathrm{H}$ NMR (300.13 MHz, $\left.298 \mathrm{~K}, \mathrm{C}_{6} \mathrm{D}_{6}, \mathrm{ppm}\right): \delta=1.02\left(\mathrm{~d}, 2 \times 3 \mathrm{H},{ }^{3} J_{\mathrm{HH}}=6.8 \mathrm{~Hz}, \mathrm{CH}\left(\mathrm{CH}_{3}\right)_{2}\right)$, $1.12\left(\mathrm{~d}, 2 \times 3 \mathrm{H},{ }^{3} J_{\mathrm{HH}}=6.8 \mathrm{~Hz}, \mathrm{CH}\left(\mathrm{CH}_{3}\right)_{2}\right), 1.41\left(\mathrm{~d}, 2 \times 3 \mathrm{H},{ }^{3} J_{\mathrm{HH}}=6.8 \mathrm{~Hz}, \mathrm{CH}\left(\mathrm{CH}_{3}\right)_{2}\right), 1.42$ $\left(\mathrm{d}, 2 \times 3 \mathrm{H},{ }^{3} J_{\mathrm{HH}}=6.8 \mathrm{~Hz}, \mathrm{CH}\left(\mathrm{CH}_{3}\right)_{2}\right), 1.52(\mathrm{~s}, 2 \times 3 \mathrm{H}, \beta-M e), 3.28\left(\mathrm{sept}, 2 \times 1 \mathrm{H},{ }^{3} J_{\mathrm{HH}}=6.8\right.$ $\left.\mathrm{Hz}, \mathrm{CH}\left(\mathrm{CH}_{3}\right)_{2}\right), 3.64$ (sept, 2 x $\left.1 \mathrm{H},{ }^{3} J_{\mathrm{HH}}=6.8 \mathrm{~Hz}, \mathrm{CH}\left(\mathrm{CH}_{3}\right)_{2}\right), 4.96$ (s, $\left.1 \mathrm{H}, \gamma-\mathrm{CH}\right), 7.04-7.14$ (m, $6 \mathrm{H}, \mathrm{Ar}-H)$.

MS (EI): $m / z(\%): 606\left(1,\left[M^{+}\right]\right), 571\left(4,\left[M^{+}-\mathrm{Cl}\right], 479\left(100,\left[M^{+}-\mathrm{I}\right]\right)\right.$.

$\mathrm{C}_{29} \mathrm{H}_{41} \mathrm{AlClIN}_{2}$ (606.97): calcd. C 57.34, H 6.81, Cl 5.32, I 20.91, N 4.62; Found: C 58.00, H 6.86, Cl 5.14, I 19.23, N 4.70.

\section{$[\mathrm{LAICl}(\mu-\mathrm{OH})]_{2}(8)$}

To a mixture of 7 (0.61 g, $1 \mathrm{mmol})$ and $\left[\mathrm{CN}(i \operatorname{Pr}) \mathrm{C}_{2} \mathrm{Me}_{2} \mathrm{~N}(i \mathrm{Pr})\right](: \mathbf{C}, 0.18 \mathrm{~g}, 1 \mathrm{mmol})$ in toluene $(40 \mathrm{~mL})$ at $0{ }^{\circ} \mathrm{C}$, distilled $\mathrm{H}_{2} \mathrm{O}(18 \mu \mathrm{L}, 1 \mathrm{mmol})$ was added. The suspension was allowed to warm to room temperature and stirred for $12 \mathrm{~h}$. The insoluble solid was removed by filtration and the filtrate was dried in vacuo and extracted with $n$-hexane $(10 \mathrm{~mL})$. The extract was kept at $4{ }^{\circ} \mathrm{C}$ to afford colorless crystals of $\mathbf{8}$. X-ray quality crystals of $\mathbf{8}$ were grown from $n$-hexane and contained one molecule of $n$-hexane.

Yield: 0.35 g, $70 \%$. M.p. $>177^{\circ} \mathrm{C}$ (decomp.).

${ }^{1} \mathrm{H}$ NMR (500.13 MHz, $\left.298 \mathrm{~K}, \mathrm{C}_{6} \mathrm{D}_{6}, \mathrm{ppm}\right): \delta=0.72(\mathrm{~s}, 2 \mathrm{H}, \mathrm{OH}), 1.12\left(\mathrm{~d}, 2 \times 3 \mathrm{H},{ }^{3} J_{\mathrm{HH}}=\right.$ $\left.6.8 \mathrm{~Hz}, \mathrm{CH}\left(\mathrm{CH}_{3}\right)_{2}\right), 1.13\left(\mathrm{~d}, 2 \times 3 \mathrm{H},{ }^{3} J_{\mathrm{HH}}=6.8 \mathrm{~Hz}, \mathrm{CH}\left(\mathrm{CH}_{3}\right)_{2}\right), 1.33\left(\mathrm{~d}, 2 \times 3 \mathrm{H},{ }^{3} J_{\mathrm{HH}}=6.8\right.$ $\left.\mathrm{Hz}, \mathrm{CH}\left(\mathrm{CH}_{3}\right)_{2}\right), 1.48\left(\mathrm{~d}, 2 \times 3 \mathrm{H},{ }^{3} \mathrm{~J}_{\mathrm{HH}}=6.8 \mathrm{~Hz}, \mathrm{CH}\left(\mathrm{CH}_{3}\right)_{2}\right), 1.66(\mathrm{~s}, 2 \times 3 \mathrm{H}, \beta-\mathrm{Me}), 3.42$ (sept, $\left.2 \times 1 \mathrm{H},{ }^{3} J_{\mathrm{HH}}=6.8 \mathrm{~Hz}, \mathrm{CH}\left(\mathrm{CH}_{3}\right)_{2}\right), 3.47$ (sept, $\left.2 \times 1 \mathrm{H},{ }^{3} J_{\mathrm{HH}}=6.8 \mathrm{~Hz}, \mathrm{CH}\left(\mathrm{CH}_{3}\right)_{2}\right), 4.90$ (s, $1 \mathrm{H}, \gamma-\mathrm{CH}), 7.04-7.12(\mathrm{~m}, 6 \mathrm{H}, \mathrm{Ar}-H)$.

${ }^{1} \mathrm{H}$ NMR (200.13 MHz, $298 \mathrm{~K}, \mathrm{D}_{8}$-toluene, ppm): $\delta=0.69$ (s, $\left.2 \mathrm{H}, \mathrm{OH}\right), 1.12$ (d, 4 x $3 \mathrm{H}$, $\left.{ }^{3} J_{\mathrm{HH}}=6.8 \mathrm{~Hz}, \mathrm{CH}\left(\mathrm{CH}_{3}\right)_{2}\right), 1.33\left(\mathrm{~d}, 2 \times 3 \mathrm{H},{ }^{3} J_{\mathrm{HH}}=6.8 \mathrm{~Hz}, \mathrm{CH}\left(\mathrm{CH}_{3}\right)_{2}\right), 1.46\left(\mathrm{~d}, 2 \times 3 \mathrm{H},{ }^{3} J_{\mathrm{HH}}\right.$ $\left.=6.8 \mathrm{~Hz}, \mathrm{CH}\left(\mathrm{CH}_{3}\right)_{2}\right), 1.58(\mathrm{~s}, 2 \times 3 \mathrm{H}, \beta-\mathrm{Me}), 3.40\left(\mathrm{sept}, 4 \times 1 \mathrm{H},{ }^{3} \mathrm{~J}_{\mathrm{HH}}=6.8 \mathrm{~Hz}, \mathrm{CH}\left(\mathrm{CH}_{3}\right)_{2}\right)$, $4.94(\mathrm{~s}, 1 \mathrm{H}, \gamma-\mathrm{CH}), 6.96-7.20(\mathrm{~m}, 6 \mathrm{H}, \mathrm{Ar}-\mathrm{H})$.

${ }^{27} \mathrm{Al}$ NMR (78.20 MHz, $298 \mathrm{~K}, \mathrm{C}_{6} \mathrm{D}_{6}$, ppm): no resonances were observed.

MS (EI): $m / z(\%): 496.3\left(50,\left[M^{+} / 2\right]\right), 478.3\left(16,\left[M^{+} / 2-\mathrm{OH}-1\right], 461.3\left(100,\left[M^{+} / 2-\mathrm{Cl}\right]\right)\right.$.

IR (KBr plate, Nujol mull, $\left.\mathrm{cm}^{-1}\right): v=3459$ (broad, $\left.\mathrm{OH}\right)$.

$\mathrm{C}_{58} \mathrm{H}_{84} \mathrm{Al}_{2} \mathrm{Cl}_{2} \mathrm{~N}_{4} \mathrm{O}_{2}$ (994.21): calcd. C 70.07, H 8.52, N 5.64; Found: C 69.34, H 8.69, N 5.34.

\section{$\mathrm{LAl}(\mathrm{OH})_{2}(9)$}


The synthetic procedure for $\mathbf{9}$ resembled that of $\mathbf{8}$ with the starting materials $\mathbf{8}$, $\left[\mathrm{CN}(i \mathrm{Pr}) \mathrm{C}_{2} \mathrm{Me}_{2} \mathrm{~N}(i \mathrm{Pr})\right]$, and $\mathrm{H}_{2} \mathrm{O}$ in molar ratio of $1: 2: 2$. After workup, by filtration to remove insoluble solids and drying in vacuo the $n$-hexane extract was kept at $4{ }^{\circ} \mathrm{C}$ for $3 \mathrm{~d}$ to afford colorless crystals of 9 (25\%). The spectrometric and spectroscopic data (EI-MS, IR, ${ }^{1} \mathrm{H}$ NMR) are almost the same as those described in literature. The characteristic data for the AlOH functionality are listed here: ${ }^{1} \mathrm{H}$ NMR (300.13 MHz, $298 \mathrm{~K}, \mathrm{D}_{8}$-toluene, ppm): $\delta=0.27$ (s, 2 x $1 \mathrm{H}, \mathrm{OH})$; IR (KBr plate, Nujol mull, $\left.\mathrm{cm}^{-1}\right): v=3448$ (broad, OH). The X-ray single crystal diffraction analysis confirms the same set of data reported for complex 9.

\section{$\left[\mathrm{LAlO}_{2}(\mathbf{1 0})\right.$}

A toluene solution $(20 \mathrm{~mL})$ of $\mathrm{LAl}(0.44 \mathrm{~g}, 1 \mathrm{mmol})$ in $100 \mathrm{~mL}$ Schlenk flask was cooled to $78^{\circ} \mathrm{C}$. The $\mathrm{N}_{2}$ atmosphere in the flask was exchanged to $\mathrm{O}_{2}\left(\mathrm{O}_{2}\right.$ gas was predried with $\left.\mathrm{P}_{4} \mathrm{O}_{10}\right)$. In the course of stirring and warming to room temperature the color of the solution slowly changed from red to orange, to yellow, and finally to very light yellow, and at ca. $-15{ }^{\circ} \mathrm{C} \mathrm{a}$ colorless crystalline solid started to form from the very light yellow solution. After additional stirring for $2 \mathrm{~h}$, the solvent was removed in vacuo and the residue was washed with $n$-hexane (2 $\mathrm{mL})$ to give crystalline $\mathbf{1 0}$.

Yield: $0.37 \mathrm{~g}(80 \%)$. M.p. $314-315^{\circ} \mathrm{C}$.

${ }^{1} \mathrm{H}$ NMR $\left(\mathrm{C}_{6} \mathrm{D}_{6}, 298 \mathrm{~K}, 500.13 \mathrm{MHz}, \mathrm{ppm}\right): \delta=0.22\left(\mathrm{~d},{ }^{3} J_{\mathrm{HH}}=6.7 \mathrm{~Hz}, 2 \times 3 \mathrm{H}, \mathrm{CHMe} e_{2}, 1.07\right.$ $\left(\mathrm{d},{ }^{3} J_{\mathrm{HH}}=6.7 \mathrm{~Hz}, 2 \times 3 \mathrm{H}, \mathrm{CHMe} e_{2}\right), 1.21\left(\mathrm{~d},{ }^{3} J_{\mathrm{HH}}=6.7 \mathrm{~Hz}, 2 \times 3 \mathrm{H}, \mathrm{CHMe} e_{2}\right), 1.27\left(\mathrm{~d},{ }^{3} J_{\mathrm{HH}}=\right.$ $6.7 \mathrm{~Hz}, 2 \times 3 \mathrm{H}, \mathrm{CHMe} 2), 1.28\left(\mathrm{~d},{ }^{3} J_{\mathrm{HH}}=6.7 \mathrm{~Hz}, 2 \times 3 \mathrm{H}, \mathrm{CHMe} e_{2}\right), 1.36\left(\mathrm{~s}, 2 \times 3 \mathrm{H}, \beta-\mathrm{CH}_{3}\right)$, $1.39\left(\mathrm{~d},{ }^{3} J_{\mathrm{HH}}=6.7 \mathrm{~Hz}, 2 \times 3 \mathrm{H}, \mathrm{CHMe}\right), 1.45\left(\mathrm{~d},{ }^{3} \mathrm{~J}_{\mathrm{HH}}=6.7 \mathrm{~Hz}, 2 \times 3 \mathrm{H}, \mathrm{CHMe}\right), 1.49(\mathrm{~d}$, $\left.{ }^{3} J_{\mathrm{HH}}=6.7 \mathrm{~Hz}, 2 \times 3 \mathrm{H}, \mathrm{CHMe} e_{2}\right), 1.52\left(\mathrm{~s}, 2 \times 3 \mathrm{H}, \beta-\mathrm{CH}_{3}\right), 2.63\left(\mathrm{sept},{ }^{3} J_{\mathrm{HH}}=6.7 \mathrm{~Hz}, 2 \times 1 \mathrm{H}\right.$, $\left.\mathrm{CHMe}_{2}\right), 3.22\left(\mathrm{sept},{ }^{3} J_{\mathrm{HH}}=6.7 \mathrm{~Hz}, 2 \times 1 \mathrm{H}, \mathrm{C} H \mathrm{Me}_{2}\right), 3.57\left(\mathrm{sept},{ }^{3} J_{\mathrm{HH}}=6.7 \mathrm{~Hz}, 2 \times 1 \mathrm{H}\right.$, $\left.\mathrm{C} H \mathrm{Me}_{2}\right), 3.83\left(\mathrm{sept}^{3} J_{\mathrm{HH}}=6.7 \mathrm{~Hz}, 2 \times 1 \mathrm{H}, \mathrm{CHMe}\right.$ ), $4.71(\mathrm{~s}, 2 \times 1 \mathrm{H}, \gamma \mathrm{CH}), 6.98-7.10,7.15-$ $7.31(\mathrm{~m}, 12 \mathrm{H}, \mathrm{Ar}-H)$.

${ }^{13} \mathrm{C}$ NMR $\left(\mathrm{C}_{6} \mathrm{D}_{6}, 298 \mathrm{~K}, 125.8 \mathrm{MHz}, \mathrm{ppm}\right): \delta=22.2,23.4,24.2,24.5,25.0,25.7,26.4,26.8$, 27.2, 27.7, 29.1, 31.5, $32.4\left(\mathrm{CHMe}_{2}\right.$ and $\left.\beta-\mathrm{CH}_{3}\right), 71.4\left(\mathrm{CHMe}_{2}\right), 97.8(\gamma-C), 122.7,124.2$, $125.3,125.7,126.9,127.7,128.9,142.0,143.7,145.7,146.2,148.1\left(\mathrm{Ar}-C_{6} \mathrm{H}_{3}\right), 168.1(C \mathrm{~N})$.

MS (EI) (m/z (\%)): $920.4(30)\left[M^{+}\right], 403.3(100)[\mathrm{L}-\mathrm{Me}]$.

$\mathrm{C}_{58} \mathrm{H}_{82} \mathrm{Al}_{2} \mathrm{~N}_{4} \mathrm{O}_{2}$ (921.29) (\%): calcd. C 75.62, H 8.97, N 6.08; found C 75.20, H 9.02, N 6.21.

\section{$[\mathrm{LAl}(\mathrm{OH})]_{2}(\mu-\mathrm{O})(\mathbf{1 1})$ :}

To a suspension of $\mathbf{1 0}$ in toluene $(30 \mathrm{~mL})$ one equiv of $\mathrm{H}_{2} \mathrm{O}$ was added at $0{ }^{\circ} \mathrm{C}$. The mixture 
was allowed to warm to room temperature and stirred for $12 \mathrm{~h}$ to give a clear solution. All volatiles were removed and the residue was recrystallized in toluene $/ n$-hexane at $-26{ }^{\circ} \mathrm{C}$. The colorless crystals of 11.1.5 $n$-hexane were obtained and determined by X-ray structural analysis. The cell parameters are almost the same as those for $\mathbf{1 1} \cdot n$-hexane $\cdot 0.5$ toluene. 11·1.5 $n$-hexane: $a=13.677(1), b=21.289(1), c=23.014(1) \AA, \beta=104.69(1)^{\circ}, V=6482(1) \AA^{3}$; 11 $n$-hexane $\cdot 0.5$ toluene: $a=13.731(3), b=21.352(4), c=22.877(5) \AA, \beta=103.58(3)^{\circ}, V=$ 6520(1) $\AA^{3}$.

\section{$\left\{\mathrm{HC}[(\mathrm{CMe})(\mathrm{NAr})]\left[(\mathrm{CMe})\left(\mathrm{N}-\mathrm{C}_{6} \mathrm{H}_{3}-2-i \operatorname{Pr}-6-\mathrm{CH}\left(\mathrm{CH}_{2}\right)(\mathrm{Me})\right]\right\} \mathrm{Al}\left(\mathrm{NHAr}{ }^{\prime \prime}\right)\right.$}

(12),

\section{$\left[\left\{\mathrm{HC}[(\mathrm{CMe})(\mathrm{NAr})]\left[(\mathrm{CMe})\left(\mathrm{N}-\mathrm{C}_{6} \mathrm{H}_{3}-2-i \operatorname{Pr}-6-\mathrm{CH}\left(\mathrm{CH}_{2}\right)(\mathrm{Me})\right]\right\} \mathrm{Al}(\mu-\mathrm{OH})\right]_{2}\right.$}

The reaction procedure is the same as that in the preparation of $\mathbf{2 5}$ and $\mathbf{2 6}$, and LAl $(0.47 \mathrm{~g}$, $1.07 \mathrm{mmol})$ and $\mathrm{N}_{3} \mathrm{Ar}$ ' $(0.38 \mathrm{~g}, 1.07 \mathrm{mmol})$ are used. After workup, the solution was dried in vacuum and the residue was washed with $n$-hexane $(2 \mathrm{~mL})$ to afford colorless crystalline solids. The melting point is $218-219^{\circ} \mathrm{C}$, however, the proton NMR spectrum indicates two sets of resonances, which may correspond two different compounds. By recrystallization in $n$ hexane/toluene, compounds $\mathbf{1 2}$ and $\mathbf{1 3}$ are isolated one by one both as colorless crystals.

12: yield: 0.48 g, $56 \%$. M.p. $194-195^{\circ} \mathrm{C}$.

${ }^{1} \mathrm{H}$ NMR (300.13 MHz, $\left.\mathrm{C}_{6} \mathrm{D}_{6}, 298 \mathrm{~K}, \mathrm{ppm}\right): \delta=-0.94\left(\mathrm{dd}, 1 \mathrm{H},{ }^{2} J_{\mathrm{HH}}=-15.1 \mathrm{~Hz},{ }^{3} J_{\mathrm{HH}}=7.7\right.$ $\left.\mathrm{Hz}, \mathrm{Al}-\mathrm{CH}_{2}\right),-0.19\left(\mathrm{dd}, 1 \mathrm{H},{ }^{2} J_{\mathrm{HH}}=-15.1 \mathrm{~Hz},{ }^{3} J_{\mathrm{HH}}=2.0 \mathrm{~Hz}, \mathrm{Al}-\mathrm{CH}_{2}\right), 0.66,0.90,0.97,1.14$, $1.18,1.19,1.22\left(\mathrm{~d}, 7 \times 3 \mathrm{H},{ }^{3} J_{\mathrm{HH}}=6.6 \mathrm{~Hz}, \mathrm{CH}\left(\mathrm{CH}_{3}\right)_{2}\right), 1.44,1.52\left(\mathrm{~s}, 2 \times 3 \mathrm{H}, \beta-\mathrm{CH}_{3}\right), 1.59$, 1.76, 2.13, 2.19, 2.25, 2.34 (s, 6 × 3 H, Ar'"-Me), 2.50, 2.79, $3.33\left(\mathrm{sept}, 3\right.$ x $1 \mathrm{H},{ }^{3} \mathrm{~J}_{\mathrm{HH}}=6.6$ $\left.\mathrm{Hz}, \mathrm{CH}\left(\mathrm{CH}_{3}\right)_{2}\right), 3.04\left(\mathrm{~m}, 1 \mathrm{H}, \mathrm{CH}\left(\mathrm{CH}_{3}\right)\left(\mathrm{CH}_{2}\right)\right), 3.47$ (s, $\left.1 \mathrm{H}, \mathrm{NH}\right), 4.83$ (s, $\left.1 \mathrm{H}, \gamma-\mathrm{CH}\right)$, 6.62-7.20 (m, $13 \mathrm{H}, \mathrm{Ar}-H)$.

${ }^{13} \mathrm{C}$ NMR (125.76 MHz, $\left.\mathrm{C}_{6} \mathrm{D}_{6}, 298 \mathrm{~K}, \mathrm{ppm}\right): \delta=20.25,21.06,21.13,21.17,22.16,22.25$, $23.00,24.31,24.77,24.83,24.84,24.95,25.13,26.05,26.90,27.66,28.08,28.72,31.91$, $40.37\left(\beta-\mathrm{CH}_{3}, \mathrm{CH}\left(\mathrm{CH}_{3}\right)_{2}, \mathrm{CH}\left(\mathrm{CH}_{3}\right)\left(\mathrm{CH}_{2}\right), \mathrm{Ar}{ }^{\prime}-M e\right), 98.66(\gamma-\mathrm{CH}), 116.28,118.60,124.64$, 124.72 , 125.22, 127.43, 129.00, 129.40, 136.88, 137.04, 140.46, 141.46, 144.44, 144.80, 146.06, 146.27, $148.89(\mathrm{Ar}-C), 131.2(\mathrm{br}, \mathrm{Al}-C), 169.97(C \mathrm{~N})$.

IR (KBr plate, Nujol mull, $\left.\mathrm{cm}^{-1}\right): v=3265(\mathrm{NH})$.

MS (EI): $m / z(\%): 771.7\left(10,\left[M^{+}\right]\right), 443.4\left(100,\left[M^{+}-\mathrm{NHAr} \mathbf{r}^{\prime}-1\right]\right.$.

$\mathrm{C}_{53} \mathrm{H}_{66} \mathrm{AlN}_{3}$ (771.743): calcd. C 82.45, H 8.62, N 5.44. Found: C 82.32, H 8.55, N 5.51.

13: yield: 0.23 g, $23 \%$. M.p. $333-335^{\circ} \mathrm{C}$. 
${ }^{1} \mathrm{H}$ NMR (300.13 MHz, $\left.\mathrm{C}_{6} \mathrm{D}_{6}, 298 \mathrm{~K}, \mathrm{ppm}\right): \delta=-1.69\left(\mathrm{t}, 1 \mathrm{H},{ }^{2} J_{\mathrm{HH}}=-14.2 \mathrm{~Hz},{ }^{3} J_{\mathrm{HH}}=14.2\right.$ $\left.\mathrm{Hz}, \mathrm{Al}-\mathrm{CH}_{2}\right),-0.35\left(\mathrm{dd}, 1 \mathrm{H},{ }^{2} J_{\mathrm{HH}}=-14.2 \mathrm{~Hz},{ }^{3} J_{\mathrm{HH}}=3.5 \mathrm{~Hz}, \mathrm{Al}-\mathrm{CH}_{2}\right), 0.29(\mathrm{~s}, 2 \times 1 \mathrm{H}$, $\mathrm{OH}), 0.74,0.86,0.90,1.03,1.17,1.28,1.32\left(\mathrm{~d}, 7 \times 3 \mathrm{H},{ }^{3} J_{\mathrm{HH}}=6.6 \mathrm{~Hz}, \mathrm{CH}\left(\mathrm{CH}_{3}\right)_{2}\right), 1.42,1.59$ (s, $\left.2 \times 3 \mathrm{H}, \beta-\mathrm{CH}_{3}\right), 2.47,2.78,2.99$ (sept, $\left.3 \times 1 \mathrm{H},{ }^{3} J_{\mathrm{HH}}=6.6 \mathrm{~Hz}, \mathrm{CH}\left(\mathrm{CH}_{3}\right)_{2}\right), 2.60(\mathrm{~m}, 1 \mathrm{H}$, $\left.\mathrm{CH}\left(\mathrm{CH}_{3}\right)\left(\mathrm{CH}_{2}\right)\right), 4.93(\mathrm{~s}, 1 \mathrm{H}, \gamma-\mathrm{CH}), 6.80-7.20(\mathrm{~m}, 12 \mathrm{H}, \mathrm{Ar}-H)$.

${ }^{13} \mathrm{C}$ NMR (125.76 MHz, $\left.\mathrm{C}_{6} \mathrm{D}_{6}, 298 \mathrm{~K}, \mathrm{ppm}\right): \delta=20.59,20.87,21.26,21.90,22.44,22.89$, $24.06,24.33,24.97,25.42,26.60,26.89,28.37,28.53,31.91,33.79\left(\beta-\mathrm{CH}_{3}, C \mathrm{H}\left(C_{3}\right)_{2}\right.$, $\left.\mathrm{CH}\left(\mathrm{CH}_{3}\right)\left(\mathrm{CH}_{2}\right)\right), 100.09(\gamma-\mathrm{CH}), 116.55,123.91,124.68,126.88,127.81,132.10,141.46$, 143.29, 144.11, 145.52, 146.16, $148.30(\mathrm{Ar}-C), 134.2$ (br, Al-C), $168.11(C \mathrm{~N})$.

IR (KBr plate, Nujol mull, $\left.\mathrm{cm}^{-1}\right): v=3400$ (br., OH).

MS (EI): $m / z(\%): 920.6\left(2,\left[M^{+}\right]\right), 887.6\left(100,\left[M^{+}-2 \mathrm{Me}-2 \mathrm{H}-1\right]\right.$.

$\mathrm{C}_{58} \mathrm{H}_{80} \mathrm{AlN}_{4} \mathrm{O}_{2}$ (921.234): calcd. C 75.62, H 8.97, N 6.08. Found: C 75.48, H 8.85, N 6.11.

After the collection of crystals of 12 and 13, the mother liquor was kept at $4{ }^{\circ} \mathrm{C}$ for three weeks. A small amounts of colorless crystals of $\mathrm{H}_{2} \mathrm{NAr}$ ' were obtained and collected by filtration.

${ }^{1} \mathrm{H}$ NMR (500.13 MHz, $\left.\mathrm{C}_{6} \mathrm{D}_{6}, 298 \mathrm{~K}, \mathrm{ppm}\right): \delta=1.35$ (s, br, $\left.2 \mathrm{H}, \mathrm{N} H_{2}\right), 2.06(\mathrm{~s}, 4$ x $3 \mathrm{H}, o-$ Ar'-Me), 2.20 (s, 2 x 3 H, p-Ar'-Me), 6.84-6.87, 7.07-7.10 (m, 7 H, Ar-H).

${ }^{13} \mathrm{C}$ NMR (125.76 MHz, $\left.\mathrm{C}_{6} \mathrm{D}_{6}, 298 \mathrm{~K}, \mathrm{ppm}\right): \delta=20.53$ (o-Ar'-Me), 21.19 (p-Ar'-Me), $128.88,129.03,130.26,135.33,136.43,137.17,142.53,147.95(\mathrm{Ar}-C)$.

IR (KBr plate, Nujol mull, $\left.\mathrm{cm}^{-1}\right): v=3468,3472(\mathrm{NH})$.

Correct elemental analysis.

\section{[HC $\left.\left\{\mathrm{C}\left(\mathrm{CH}_{2}\right) \mathrm{NAr}\right\}(\mathrm{CMeNAr})\right] \mathrm{AlH}\left[\mathrm{CN}(i \mathrm{Pr}) \mathrm{C}_{2} \mathrm{Me}_{2} \mathrm{~N}(\mathrm{iPr})\right](14)$}

Method A: The suspension of $\mathrm{LAlI}_{2}(2.08 \mathrm{~g}, 3.0 \mathrm{mmol})$ and finely divided potassium $(0.25 \mathrm{~g}$, $6.3 \mathrm{mmol})$ in toluene $(50 \mathrm{~mL})$ was stirred violently for $3 \mathrm{~d}$ at room temperature till all the potassium disappeared. After filtration the dark-red filtrate was slowly dried in vacuum and some red microcrystals of LAl were observed depositing on the wall of the flask. To the remaining solid $\left[\mathrm{CN}(i \mathrm{Pr}) \mathrm{C}_{2} \mathrm{Me}_{2} \mathrm{~N}(i \mathrm{Pr})\right](0.36 \mathrm{~g}, 2 \mathrm{mmol})$ was added. The mixture was allowed slowly to heat to ca. $120{ }^{\circ} \mathrm{C}$ and kept for $5 \mathrm{~h}$. After cooling to room temperature, the yellow product was extracted with hot toluene $(30 \mathrm{~mL})$ and the extract was kept at room temperature for $24 \mathrm{~h}$ to afford X-ray quality colorless block crystals of $\mathbf{1 4}$, which were collected by filtration $(0.42 \mathrm{~g})$. The mother liquor was concentrated (ca. $5 \mathrm{~mL})$ and kept at $4{ }^{\circ} \mathrm{C}$ for $24 \mathrm{~h}$ to give another crop of colorless crystals $(0.25 \mathrm{~g})$.

Total yield of 14: $0.67 \mathrm{~g}\left(47 \%\right.$, based on $\left.\left[\mathrm{CN}(i \mathrm{Pr}) \mathrm{C}_{2} \mathrm{Me}_{2} \mathrm{~N}(i \mathrm{Pr})\right]\right)$. M.p. $298-300^{\circ} \mathrm{C}\left(>250{ }^{\circ} \mathrm{C}\right.$ 
decomp.).

${ }^{1} \mathrm{H}$ NMR $\left(300.13 \mathrm{~Hz}, 300 \mathrm{~K}, \mathrm{C}_{6} \mathrm{D}_{6}, \mathrm{ppm}\right): \delta=0.38,0.50,0.76,0.82,1.19,1.32,1.46,1.50$, $1.53,1.55,1.57,1.59(\mathrm{~d}, 12 \times 3 \mathrm{H}, \mathrm{CHMe} 2$ and $\mathrm{N}(\mathrm{CHMe})), 1.38,1.62\left(\mathrm{~s}, 2 \times 3 \mathrm{H}, \mathrm{C}_{2} \mathrm{Me}_{2}\right)$, $1.72\left(\mathrm{~s}, 3 \mathrm{H}, \beta-\mathrm{CH}_{3}\right), 3.30,3.98\left(\mathrm{~s}, 2 \times 1 \mathrm{H}, \beta-\mathrm{CH}_{2}\right), 3.28,3.62,4.18,4.26(\mathrm{sept}, 4 \times 1 \mathrm{H}$, $\left.\mathrm{CHMe}_{2}\right), 4.80$ (br, 1H, Al-H), $5.60(\mathrm{~s}, 1 \mathrm{H}, \gamma \mathrm{CH}), 5.44,5.62$ (sept, $2 \times 1 \mathrm{H}, \mathrm{N}(\mathrm{CHMe})$ ), 7.10-7.38 (m, 6H, Ar-H).

${ }^{13} \mathrm{C}$ NMR $\left(300.13 \mathrm{~Hz}, 300 \mathrm{~K}, \mathrm{C}_{6} \mathrm{D}_{6}, \mathrm{ppm}\right): \delta=9.9,10.0\left(\mathrm{C}_{2} M e_{2}\right), 20.7,21.1,21.4,22.0,23.3$, 23.7, 23.8, 24.4, 24.5, 24.7, 25.6, 25.7, 26.4, 27.1, 27.7, 28.4, $28.9\left(\mathrm{~N}(\mathrm{CHMe}), \mathrm{CHMe}_{2}\right.$, $\mathrm{CHMe} 2$ and $\left.\beta-\mathrm{CH}_{3}\right), 50.9,53.0\left(\mathrm{~N}\left(\mathrm{CHMe}_{2}\right)\right), 80.8\left(\beta-\mathrm{CH}_{2}\right), 106.6(\gamma-C), 123.0,124.5,124.7$, $124.9,125.6,126.6,127.8,128.5,129.3,143.4,144.7,145.6,146.1,147.2,148.4,149.0$ $\left(\mathrm{Ar}-C, C \mathrm{~N}\right.$ and $\left.C_{2} \mathrm{Me}_{2}\right), 154.5(\mathrm{Al}-C)$.

${ }^{27} \mathrm{Al} \mathrm{NMR}(79.2 \mathrm{~Hz}, 300 \mathrm{~K}$, toluene-d 8 , ppm): no resonances were observed.

IR $\left(\mathrm{KBr}\right.$ plate, Nujol, $\left.\mathrm{cm}^{-1}\right): v=1809(\mathrm{~m}, \mathrm{Al}-\mathrm{H}), v=1619(\mathrm{~m}, \mathrm{C}=\mathrm{C})$.

MS (EI) (m/z (\%)): $624(5)\left[M^{+}\right], 609$ (40) $\left[M^{+}-\mathrm{Me}\right], 581(100)\left[M^{+}-i \mathrm{Pr}\right]$.

$\mathrm{C}_{40} \mathrm{H}_{61} \mathrm{AlN}_{4}$ (624.94): calcd. C 76.87, H 9.84, N 8.97; found C 77.07, H 9.55, N 8.86.

Method B: The suspension of $\mathrm{LAlI}_{2}(2.08 \mathrm{~g}, 3.0 \mathrm{mmol}),\left[\mathrm{CN}(i \mathrm{Pr}) \mathrm{C}_{2} \mathrm{Me} \mathrm{e}_{2} \mathrm{~N}(i \mathrm{Pr})\right](0.54 \mathrm{~g}, 3$ $\mathrm{mmol})$ and finely divided potassium $(0.25 \mathrm{~g}, 6.3 \mathrm{mmol})$ in toluene $(50 \mathrm{~mL})$ was stirred intensively for $3 \mathrm{~d}$ at room temperature till all the potassium disappeared. After filtration the orange filtrate was concentrated (ca. $20 \mathrm{~mL})$ and $n$-hexane $(20 \mathrm{~mL})$ was added. The solution was kept at $4{ }^{\circ} \mathrm{C}$ for one week to afford colorless block crystals $(0.72 \mathrm{~g})$. The mother liquor was further concentrated (ca. $5 \mathrm{~mL}$ ) and kept at $4{ }^{\circ} \mathrm{C}$ for $2 \mathrm{~d}$ to give another crop of colorless crystals (0.32 g). Total yield of 14.toluene: $1.04 \mathrm{~g}(48 \%)$. The IR, ${ }^{1} \mathrm{H}$ and ${ }^{13} \mathrm{C}$ NMR spectral data are essentially the same as those of $\mathbf{1 4}$ except for one extra molecule of toluene.

\section{[HC $\left.\left\{\mathrm{C}\left(\mathrm{CH}_{2}\right) \mathrm{NAr}\right\}(\mathrm{CMeNAr})\right] \mathrm{AlH}\left[\mathrm{CN}(\mathrm{Me}) \mathrm{C}_{2} \mathrm{Me}_{2} \mathrm{~N}(\mathrm{Me})\right](15)$}

Compound 15 was prepared in a similar manner (method A) as 14. LAlI $_{2}(2.08 \mathrm{~g}, 3.0 \mathrm{mmol})$, finely divided potassium $(0.25 \mathrm{~g}, 6.3 \mathrm{mmol})$ and $\left[\mathrm{CN}(\mathrm{Me}) \mathrm{C}_{2} \mathrm{Me}_{2} \mathrm{~N}(\mathrm{Me})\right](0.24 \mathrm{~g}, 2.0 \mathrm{mmol})$ were used. The extract $(10 \mathrm{~mL})$ was added to $n$-hexane $(10 \mathrm{~mL})$ and kept at $-26^{\circ} \mathrm{C}$ for $48 \mathrm{~h}$ to afford colorless crystals of $\mathbf{1 5}$.

Yield: $0.42 \mathrm{~g}, 25 \%$, based on $\left[\mathrm{CN}(\mathrm{Me}) \mathrm{C}_{2} \mathrm{Me}_{2} \mathrm{~N}(\mathrm{Me})\right]$. M.p. $252-253{ }^{\circ} \mathrm{C}$.

${ }^{1} \mathrm{H}$ NMR $(300.13 \mathrm{~Hz}, 300 \mathrm{~K}$, toluene-d $8, \mathrm{ppm}): \delta=1.45,1.47\left(\mathrm{~s}, 2 \times 3 \mathrm{H}, \mathrm{C}_{2} \mathrm{Me}_{2}\right), 0.29,0.30$, 1.16, 1.46, 1.58, 1.60, 1.61, 1.62 (d, $8 \times 3 \mathrm{H}, \mathrm{CHMe} 2), 1.69$ (s, 3H, $\left.\beta-\mathrm{CH}_{3}\right), 3.70,3.75(\mathrm{~s}, 2 \times$ 
$3 \mathrm{H}, \mathrm{N}(\mathrm{Me})$ ), 3.10, $3.85\left(\mathrm{~s}, 2 \times 1 \mathrm{H}, \beta-\mathrm{CH}_{2}\right), 3.21,3.25,4.15,4.21$ (sept, $\left.4 \times 1 \mathrm{H}, \mathrm{CHMe}_{2}\right), 4.80$ (br, $1 \mathrm{H}, \mathrm{Al}-H), 5.39(\mathrm{~s}, 1 \mathrm{H}, \gamma \mathrm{CH}), 7.04-7.38(\mathrm{~m}, 6 \mathrm{H}, \mathrm{Ar}-H)$.

${ }^{13} \mathrm{C}$ NMR $(300.13 \mathrm{~Hz}, 300 \mathrm{~K}$, toluene-d $8, \mathrm{ppm}): \delta=7.9,8.0\left(\mathrm{C}_{2} \mathrm{Me}_{2}\right), 23.6,24.0,24.2,24.3$, 24.8, 24.9, 25.4, 25.8, 26.0, 26.4, 26.5, 27.1, 27.8, 28.7, $29.0\left(\mathrm{~N}(\mathrm{Me}), \mathrm{CHMe}_{2}, \mathrm{CHMe}_{2}\right.$ and $\beta$ $\left.C \mathrm{H}_{3}\right), 80.1\left(\beta-\mathrm{CH}_{2}\right), 102.3(\gamma-C), 122.9,123.7,124.2,124.6,124.9,125.1,125.3,127.7$, 128.0, 143.2, 143.8, 145.4, 146.3, 147.4, 148.2, $149.0\left(\mathrm{Ar}-C, C \mathrm{~N}\right.$ and $\left.C_{2} \mathrm{Me}_{2}\right), 155.2(\mathrm{Al}-C)$. MS (EI) $(m / z(\%)): 568(15)\left[M^{+}\right], 553(100)\left[M^{+}-\mathrm{Me}\right]$.

IR (KBr plate, Nujol, $\left.\mathrm{cm}^{-1}\right): v=1810(\mathrm{~m}, \mathrm{Al}-\mathrm{H}), v=1616(\mathrm{~m}, \mathrm{C}=\mathrm{C})$.

$\mathrm{C}_{36} \mathrm{H}_{53} \mathrm{AlN}_{4}$ (568.83): calcd. C 76.01, H 9.29, N 9.85; found C 76.50, H 9.60, N 9.40.

\section{$\operatorname{LAl}\left(\mathbf{N}=\mathrm{CPh}_{2}\right)_{2}(\mathbf{1 6})$}

A solution of $\mathrm{N}_{2} \mathrm{CPh}_{2}(0.37 \mathrm{~g}, 1.90 \mathrm{mmol})$ in toluene $(15 \mathrm{~mL})$ was added to a solution of LAl $(0.42 \mathrm{~g}, 0.94 \mathrm{mmol})$ in toluene $(25 \mathrm{~mL})$ at room temperature. The mixture was slowly heated to $60{ }^{\circ} \mathrm{C}$ and kept for $12 \mathrm{~h}$, and a yellow colored solution developed. All volatiles were removed in vacuum. The residue was washed with $n$-hexane $(5 \mathrm{~mL})$ to afford an orangeyellow crystalline solid of $\mathbf{1 6}$. X-ray quality crystals were obtained by recrystallization from a $1: 1 n$-hexane/ether solution at $4{ }^{\circ} \mathrm{C}$ for one week.

Yield: 0.36 g, $48 \%$. M.p. $344-346{ }^{\circ} \mathrm{C}$.

${ }^{1} \mathrm{H}$ NMR $\left(300.13 \mathrm{~Hz}, 300 \mathrm{~K}, \mathrm{C}_{6} \mathrm{D}_{6}, \mathrm{ppm}\right): \delta=0.82,1.02(\mathrm{~d}, 8 \times 3 \mathrm{H}, \mathrm{CHMe} 2), 1.64(\mathrm{~s}, 2 \times 3$ $\left.\mathrm{H}, \beta-\mathrm{CH}_{3}\right), 3.21\left(\mathrm{sept}, 4 \times 1 \mathrm{H}, \mathrm{C} H \mathrm{Me}_{2}\right), 5.28(\mathrm{~s}, 1 \mathrm{H}, \gamma-\mathrm{CH}), 6.92-7.00(\mathrm{~m}, 2 \times 5 \mathrm{H}, P h)$, 7.00-7.08 (m, $2 \times 5 \mathrm{H}, \mathrm{Ph}), 7.18-7.32(\mathrm{~m}, 6 \mathrm{H}, \mathrm{Ar}-H)$.

${ }^{13} \mathrm{C}$ NMR $\left(300.13 \mathrm{~Hz}, 300 \mathrm{~K}, \mathrm{C}_{6} \mathrm{D}_{6}, \mathrm{ppm}\right): \delta=23.8,24.4,24.9,28.5\left(\mathrm{CHMe}_{2}, \mathrm{CHMe}_{2}, \beta-\right.$ $\left.\mathrm{CH}_{3}\right)$, $98.8(\gamma-C), 124.5,126.9,127.6,127.6,127.9,128.1,128.3,128.3,129.4,142.4,143.1$, 144.7 (Ar-C, Ph), $166.9\left(\mathrm{NCPh}_{2}\right), 171.0(C \mathrm{~N})$.

$\operatorname{MS}(\mathrm{EI})(\mathrm{m} / \mathrm{z}(\%)): 805(20)\left[M^{+}\right], 790(30)\left[M^{+}-\mathrm{Me}\right], 624(100)\left[M^{+}-\mathrm{NCPh}_{2}\right]$.

IR (KBr plate, Nujol, $\left.\mathrm{cm}^{-1}\right): v=1667(\mathrm{w}, \mathrm{C}=\mathrm{C}), v=1624,1554(\mathrm{w}, \mathrm{C}=\mathrm{N})$.

$\mathrm{C}_{55} \mathrm{H}_{61} \mathrm{AlN}_{4}$ (805.10): calcd. C 82.05, H 7.64, N 6.96; found C 82.11, H 7.74, N 7.05.

\section{$\operatorname{LAl}\left[\mathbf{N}(\mathrm{H})-o-\mathrm{C}_{6} \mathrm{H}_{4} \mathrm{~N}(\mathrm{Ph})\right](17)$}

Method A. A toluene solution (30 mL) of LAl (0.22 g, $0.5 \mathrm{mmol})$ and PhNNPh (0.09 g, 0.5 mmol) was stirred and allowed to heat slowly to $80{ }^{\circ} \mathrm{C}$ for $5 \mathrm{~h}$. The color of the solution changed from red to orange. The solution was reduced in vacuum (ca $10 \mathrm{~mL}$ ) and $n$-hexane was added $(10 \mathrm{~mL})$. Keeping this solution at $4{ }^{\circ} \mathrm{C}$ for one week the orange X-ray quality 
crystals of 17 were obtained ( $0.15 \mathrm{~g})$ and collected. The mother liquor was concentrated again (ca. $4 \mathrm{~mL})$ and $n$-hexane added $(8 \mathrm{~mL})$. Another crop of orange crystals $(0.10 \mathrm{~g})$ was obtained by keeping the solution at $-26^{\circ} \mathrm{C}$ for $24 \mathrm{~h}$.

Total yield: 0.25 g, $81 \%$. M.p. $260-261{ }^{\circ} \mathrm{C}$.

${ }^{1} \mathrm{H}$ NMR (300.13 MHz, $\left.298 \mathrm{~K}, \mathrm{C}_{6} \mathrm{D}_{6}, \mathrm{ppm}\right): \delta=0.90\left(\mathrm{~d},{ }^{3} J_{\mathrm{HH}}=6.8 \mathrm{~Hz}, 2\right.$ × $\left.3 \mathrm{H}, \mathrm{CH}\left(\mathrm{CH}_{3}\right)_{2}\right)$, $0.92\left(\mathrm{~d},{ }^{3} J_{\mathrm{HH}}=6.8 \mathrm{~Hz}, 2 \times 3 \mathrm{H}, \mathrm{CH}\left(\mathrm{CH}_{3}\right)_{2}\right), 1.07\left(\mathrm{~d},{ }^{3} J_{\mathrm{HH}}=6.8 \mathrm{~Hz}, 2 \times 3 \mathrm{H}, \mathrm{CH}\left(\mathrm{CH}_{3}\right)_{2}\right), 1.23$ $\left(\mathrm{d},{ }^{3} J_{\mathrm{HH}}=6.8 \mathrm{~Hz}, 2 \times 3 \mathrm{H}, \mathrm{CH}\left(\mathrm{CH}_{3}\right)_{2}\right), 1.47\left(\mathrm{~s}, 2 \times 3 \mathrm{H}, \beta-\mathrm{CH}_{3}\right), 3.05\left(\mathrm{sept},{ }^{3} J_{\mathrm{HH}}=6.8 \mathrm{~Hz}, 2 \times\right.$ $\left.1 \mathrm{H}, \mathrm{CH}\left(\mathrm{CH}_{3}\right)_{2}\right), 3.06(\mathrm{~s}, 1 \mathrm{H}, \mathrm{NH}), 3.14\left(\mathrm{sept},{ }^{3} \mathrm{~J}_{\mathrm{HH}}=6.8 \mathrm{~Hz}, 2 \mathrm{x} 1 \mathrm{H}, \mathrm{CH}\left(\mathrm{CH}_{3}\right)_{2}\right), 5.12(\mathrm{~s}, 1$ $\mathrm{H}, \gamma-\mathrm{CH}), 6.31-6.34(\mathrm{~m}, 1 \mathrm{H}), 6.58-6.66(\mathrm{~m}, 2 \mathrm{H}), 6.82-6.92(\mathrm{~m}, 3 \mathrm{H}), 6.94-7.02(\mathrm{~m}, 4 \mathrm{H})$, 7.22-7.30 (m, $4 \mathrm{H}), 7.48-7.52(\mathrm{~m}, 1 \mathrm{H})(\mathrm{Ar}-H$ and $\mathrm{Ph}-H)$.

${ }^{13} \mathrm{C}\left\{{ }^{1} \mathrm{H}\right\}$ NMR $\left(125.77 \mathrm{HMz}, 298 \mathrm{~K}, \mathrm{C}_{6} \mathrm{D}_{6}, \mathrm{ppm}\right): \delta=23.4,24.2,24.5,24.9,25.1,28.3,29.2$ $\left(\mathrm{CH}\left(\mathrm{CH}_{3}\right)_{2}, \beta-\mathrm{CH}_{3}\right), 99.2(\gamma-C), 112.3,114.0,115.1,118.8,124.0,125.1,127.9,128.2,129.0$, 139.5, 143. 1, 143.7, 145.3, $148.8(\mathrm{Ar}-C, \mathrm{Ph}-C), 171.5(C \mathrm{~N})$.

IR (KBr plate, Nujol mull, $\left.\mathrm{cm}^{-1}\right): v 3220(\mathrm{NH})$.

MS (EI): m/z (\%) $626\left(\left[M^{+}\right], 100\right)$.

$\mathrm{C}_{41} \mathrm{H}_{51} \mathrm{AlN}_{4}$ (626.87): calcd. C 78.56, H 8.20, N 8.14; Found: C 78.23, H 8.18, N 8.24.

Method B. To a toluene solution $(20 \mathrm{~mL})$ of $\mathrm{LAl}\left[\eta^{2}-\mathrm{C}_{2}\left(\mathrm{SiMe}_{3}\right)_{2}\right](0.62 \mathrm{~g}, 1 \mathrm{mmol})$ at $-50{ }^{\circ} \mathrm{C}$ was added a toluene solution $(5 \mathrm{~mL})$ of $\mathrm{PhNNPh}(0.18 \mathrm{~g}, 1 \mathrm{mmol})$. The mixture was allowed to warm to room temperature under stirring. The solution changed from black to orange. After continuing the stirring for $12 \mathrm{~h}$ the solution was dried in vacuum and washed with $n$-hexane $(10 \mathrm{~mL})$ to afford an orange crystalline solid, which was characterized as $\mathbf{1 7}$ by m.p. and EImass measurements.

\section{$\operatorname{LAl}\left(\eta^{2}-\mathbf{C}_{2} \mathbf{H}_{2}\right)(\mathbf{1 8})$}

A toluene solution $(30 \mathrm{~mL})$ of $\mathrm{LAl}(0.22 \mathrm{~g}, 0.5 \mathrm{mmol})$ at reduced pressure was cooled to -78 ${ }^{\circ} \mathrm{C}$ and exposed to dried $\mathrm{C}_{2} \mathrm{H}_{2}$. This mixture was kept in the temperature range of $-78{ }^{\circ} \mathrm{C}$ to $50{ }^{\circ} \mathrm{C}$ for $2 \mathrm{~h}$. An instant color change of the solution from red to orange was observed. All volatiles were removed and an orange crystalline solid of $\mathbf{1 8}$ was afforded. The X-ray single crystals of 18 were obtained by keeping the $n$-hexane/toluene solution of 18 at $-26{ }^{\circ} \mathrm{C}$ for one week.

Yield: > 95\%. M.p. $219^{\circ} \mathrm{C}$.

${ }^{1} \mathrm{H}$ NMR (500.13 MHz, $\left.298 \mathrm{~K}, \mathrm{C}_{6} \mathrm{D}_{6}, \mathrm{ppm}\right): \delta=1.12\left(\mathrm{~d},{ }^{3} J_{\mathrm{HH}}=6.9 \mathrm{~Hz}, 4\right.$ x $\left.3 \mathrm{H}, \mathrm{CH}\left(\mathrm{CH}_{3}\right)_{2}\right)$, $1.46\left(\mathrm{~d},{ }^{3} J_{\mathrm{HH}}=6.9 \mathrm{~Hz}, 4 \times 3 \mathrm{H}, \mathrm{CH}\left(\mathrm{CH}_{3}\right)_{2}\right), 1.53\left(\mathrm{~s}, 2 \times 3 \mathrm{H}, \beta-\mathrm{CH}_{3}\right), 3.33\left(\mathrm{sept},{ }^{3} J_{\mathrm{HH}}=6.9\right.$ 
$\left.\mathrm{Hz}, 4 \times 1 \mathrm{H}, \mathrm{CH}\left(\mathrm{CH}_{3}\right)_{2}\right), 4.89(\mathrm{~s}, 1 \mathrm{H}, \gamma-\mathrm{CH}), 7.02-7.12(\mathrm{~m}, 6 \mathrm{H}, \mathrm{Ar}-H), 8.82(\mathrm{~s}, 2 \times 1 \mathrm{H}$, $\left.\mathrm{Al}-\eta^{2}-\mathrm{CH}_{2}\right)$.

${ }^{13} \mathrm{C}$ NMR (125.77 HMz, $\left.298 \mathrm{~K}, \mathrm{C}_{6} \mathrm{D}_{6}, \mathrm{ppm}\right): \delta=23.4,24.4,24.6,28.9\left(\mathrm{CH}\left(\mathrm{CH}_{3}\right)_{2}, \beta-\mathrm{CH}_{3}\right)$, $96.5(\gamma-C), 124.4,138.8,143.9(\mathrm{Ar}-C), 172.8(C \mathrm{~N}), 177.2\left(\mathrm{broad}, \mathrm{Al}-\eta^{2}-C_{2}\right)$.

${ }^{27} \mathrm{Al}$ NMR (77.13 MHz, $\left.298 \mathrm{~K}, \mathrm{C}_{6} \mathrm{D}_{6}, \mathrm{ppm}\right)$ : the signal is too broad to be observed.

IR (KBr plate, Nujol mull, $\left.\mathrm{cm}^{-1}\right): \widetilde{v}$ 442.7(w), 529.1(w), 589.8(m), 613.5(w), 647.4(w), 712.7(m), 748.3(w), 758.5(w), 778.2(w), 801.0(s), 867.7(w), 893.9(w), 936.7(w), 1026.0(m), 1055.6(w), 1100.6(m), 1177.4(w), 1260.7(m), 1304.9(w), 1318.7(w), 1410.5(s), 1485.6(s), 1532.8(m), 1653.7(w).

MS (EI): $m / z(\%) 429.3\left(100,\left[M^{+}-\mathrm{Me}-\mathrm{C}_{2} \mathrm{H}_{2}\right]\right), 455.3\left(30,\left[M^{+}-\mathrm{Me}\right]\right), 469.3\left(20,\left[M^{+}-\right.\right.$ 1]).

$\mathrm{C}_{31} \mathrm{H}_{43} \mathrm{AlN}_{2}$ (470.68): calcd. C 79.10, H 9.21, N 5.95; Found: C 79.43, H 9.18, N 6.03.

\section{$\mathrm{LAl}(\mathrm{C} \equiv \mathrm{CH})\left(\mathrm{CH}=\mathrm{CH}_{2}\right)(\mathbf{1 9})$}

The initial procedure ( $\mathrm{LAl}(0.22 \mathrm{~g}, 0.5 \mathrm{mmol}), \mathrm{C}_{2} \mathrm{H}_{2}$ (excess), and toluene $\left.(30 \mathrm{~mL})\right)$ is the same as the synthesis of 19 . At $-50^{\circ} \mathrm{C}$, the mixture was stirred and warmed to ambient temperature within $48 \mathrm{~h}$, the color of the solution slowly turned to almost colorless. Then all volatiles were removed in vacuum and the residue was washed with $n$-hexane $(2 \mathrm{~mL})$ to afford colorless crystalline solid of $\mathbf{1 9}$. The X-ray single crystals of $\mathbf{1 9}$ were grown from the $n$-hexane solution of 19 at $4{ }^{\circ} \mathrm{C}$ within one week.

Yield: 0.22 g, 90\%. M.p. $163-164^{\circ} \mathrm{C}$.

${ }^{1} \mathrm{H}$ NMR $\left(500.13 \mathrm{MHz}, 298 \mathrm{~K}, \mathrm{D}_{8}\right.$-toluene, ppm): $\delta=1.08\left(\mathrm{~d},{ }^{3} J_{\mathrm{HH}}=6.8 \mathrm{~Hz}, 2\right.$ х $3 \mathrm{H}$, $\left.\mathrm{CH}\left(\mathrm{CH}_{3}\right)_{2}\right), 1.25\left(\mathrm{~d},{ }^{3} J_{\mathrm{HH}}=6.8 \mathrm{~Hz}, 2 \times 3 \mathrm{H}, \mathrm{CH}\left(\mathrm{CH}_{3}\right)_{2}\right), 1.28\left(\mathrm{~d}^{3} J_{\mathrm{HH}}=6.8 \mathrm{~Hz}, 2 \times 3 \mathrm{H}\right.$, $\left.\mathrm{CH}\left(\mathrm{CH}_{3}\right)_{2}\right), 1.44\left(\mathrm{~d},{ }^{3} J_{\mathrm{HH}}=6.8 \mathrm{~Hz}, 2 \times 3 \mathrm{H}, \mathrm{CH}\left(\mathrm{CH}_{3}\right)_{2}\right), 1.55\left(\mathrm{~s}, 2 \times 3 \mathrm{H}, \beta-\mathrm{CH}_{3}\right), 1.73(\mathrm{~s}, 1 \mathrm{H}$, $\mathrm{C} \equiv \mathrm{CH}), 3.23\left(\mathrm{sept},{ }^{3} J_{\mathrm{HH}}=6.8 \mathrm{~Hz}, 2 \times 1 \mathrm{H}, \mathrm{CH}\left(\mathrm{CH}_{3}\right)_{2}\right), 3.81\left(\mathrm{sept},{ }^{3} J_{\mathrm{HH}}=6.8 \mathrm{~Hz}, 2 \times 1 \mathrm{H}\right.$, $\left.\mathrm{C} H\left(\mathrm{CH}_{3}\right)_{2}\right), 4.91(\mathrm{~s}, 1 \mathrm{H}, \gamma-\mathrm{CH}), 5.79\left(\mathrm{dd},{ }^{3} J_{\mathrm{HH}(\text { trans })}=20.9 \mathrm{~Hz},{ }^{2} J_{\mathrm{HH}}=6.4 \mathrm{~Hz}, 1 \mathrm{H}\right), 6.04(\mathrm{dd}$, $\left.{ }^{3} J_{\mathrm{HH}(\mathrm{cis})}=16.5 \mathrm{~Hz},{ }^{2} J_{\mathrm{HH}}=6.4 \mathrm{~Hz}, 1 \mathrm{H}\right), 6.12\left(\mathrm{dd},{ }^{3} J_{\mathrm{HH}(\text { trans })}=20.9 \mathrm{~Hz},{ }^{3} J_{\mathrm{HH}(\mathrm{cis})}=16.5 \mathrm{~Hz}, 1 \mathrm{H}\right)$, $\left(\mathrm{CH}=\mathrm{CH}_{2}\right), 6.97-7.12(\mathrm{~m}, 6 \mathrm{H}, \mathrm{Ar}-\mathrm{H})$.

${ }^{13} \mathrm{C}$ NMR (125.76 HMz, $298 \mathrm{~K}, \mathrm{D}_{8}$-toluene, ppm): $\delta=23.4,24.5,24.7,24.8,27.2,28.2,28.6$ $\left(C \mathrm{H}\left(\mathrm{CH}_{3}\right)_{2}, \beta-\mathrm{CH}_{3}\right), 94.6(\mathrm{broad}, \equiv C \mathrm{H}), 98.4(\gamma-C), 124.1,124.8,127.5,128.8,129.2,137.1$, 140.3, 143.7, 145.4 (Ar-C), 125.4, $\left(=C \mathrm{H}_{2}\right), 137.3$ (broad, $\left.\mathrm{Al}-C \equiv\right), 138.0$ (broad, Al-C=), $170.6(\mathrm{CN})$.

IR (KBr plate, Nujol mull, $\left.\mathrm{cm}^{-1}\right): \widetilde{v} 1992(\mathrm{C} \equiv \mathrm{C}), 3277(\equiv \mathrm{CH})$.

MS (EI): m/z (\%) $469.4\left(100,\left[M^{+}-\mathrm{CH}=\mathrm{CH}_{2}\right]\right), 496.4\left(15,\left[M^{+}\right]\right)$. 
$\mathrm{C}_{33} \mathrm{H}_{45} \mathrm{AlN}_{2}$ (496.72): calcd. C 79.80, H 9.13, N 5.64; Found: C 79.26, H 9.18, N 5.56.

\section{$\operatorname{LAl}(\mathrm{C} \equiv \mathrm{CPh})(\mathrm{CPh}=\mathrm{CHPh})(\mathbf{2 0})$}

To a toluene solution $(30 \mathrm{~mL})$ of $\mathrm{LAl}\left(\eta^{2}-\mathrm{C}_{2} \mathrm{Ph}_{2}\right)(1.24 \mathrm{~g}, 2 \mathrm{mmol})$ was added a toluene solution $(10 \mathrm{~mL})$ of a little excess of $\mathrm{HC} \equiv \mathrm{CPh}(0.33 \mathrm{~mL}, 3 \mathrm{mmol})$. The mixture was stirred for $12 \mathrm{~h}$ at room temperature and dried in vacuum, and then extracted with $n$-hexane $(10 \mathrm{~mL})$. The extract was kept at $4^{\circ} \mathrm{C}$ for a week to afford colorless crystals of $20 \cdot 0.5 n$-hexane.

Yield: 1.12 g, $73 \%$. M.p. $187-190{ }^{\circ} \mathrm{C}$.

${ }^{1} \mathrm{H}$ NMR (300.13 MHz, $\left.298 \mathrm{~K}, \mathrm{C}_{6} \mathrm{D}_{6}, \mathrm{ppm}\right): \delta=0.86 \sim 0.90$ (m, $7 \mathrm{H}, n$-hexane), 1.11 (d, 2 x 3 $\left.\mathrm{H},{ }^{3} J_{\mathrm{HH}}=6.8 \mathrm{~Hz}, \mathrm{CH}\left(\mathrm{CH}_{3}\right)_{2}\right), 1.24\left(\mathrm{~d}, 4 \times 3 \mathrm{H},{ }^{3} J_{\mathrm{HH}}=6.8 \mathrm{~Hz}, \mathrm{CH}\left(\mathrm{CH}_{3}\right)_{2}\right), 1.35(\mathrm{~d}, 2 \times 3 \mathrm{H}$, $\left.{ }^{3} J_{\mathrm{HH}}=6.8 \mathrm{~Hz}, \mathrm{CH}\left(\mathrm{CH}_{3}\right)_{2}\right), 1.61\left(\mathrm{~s}, 2 \times 3 \mathrm{H}, \beta-\mathrm{CH}_{3}\right), 3.44\left(\mathrm{sept}, 2 \times 1 \mathrm{H},{ }^{3} J_{\mathrm{HH}}=6.8 \mathrm{~Hz}\right.$, $\left.\mathrm{CH}\left(\mathrm{CH}_{3}\right)_{2}\right), 4.01$ (sept, $\left.2 \times 1 \mathrm{H},{ }^{3} J_{\mathrm{HH}}=6.8 \mathrm{~Hz}, \mathrm{CH}\left(\mathrm{CH}_{3}\right)_{2}\right), 5.08$ (s, $\left.1 \mathrm{H}, \gamma-\mathrm{CH}\right), 6.72$ (broad, 1 $\mathrm{H}, \mathrm{C}=\mathrm{CH}), 6.40-6.52,6.80-7.00(\mathrm{~m}, 10 \mathrm{H}, \mathrm{C}(\mathrm{Ph})=\mathrm{CH}(P h)), 7.08-7.24,7.42-7.54(\mathrm{~m}, 6 \mathrm{H}$, $\mathrm{Ar}-H)$.

${ }^{13} \mathrm{C}$ NMR (125.76 HMz, $\left.298 \mathrm{~K}, \mathrm{C}_{6} \mathrm{D}_{6}, \mathrm{ppm}\right): \delta=14.3$ (n-hexane), 23.0, 24.5, 24.8, 24.9, 26.1, 28.7, 29.2, $31.9\left(\mathrm{CH}\left(\mathrm{CH}_{3}\right)_{2}, \beta-\mathrm{CH}_{3}\right), 99.5(\gamma-C), 106.6$ (broad, $\left.\equiv C \mathrm{Ph}\right), 124.1,124.2,125.4$, $126.4,127.1,127.4,128.0,129.6,131.4,132.0,139.1,141.3,143.2,145.9,146.7(\mathrm{Ph}-C$, $\mathrm{Ar}-C,=C), 144.4,153.8($ broad $, \mathrm{Al}-C \equiv, \mathrm{Al}-C=), 171.1(C \mathrm{~N})$.

IR (KBr plate, Nujol mull, $\left.\mathrm{cm}^{-1}\right): v 2124(\mathrm{C} \equiv \mathrm{C})$.

MS (EI): m/z (\%) $545\left(100,\left[M^{+}-\mathrm{C}(\mathrm{Ph})=\mathrm{CH}(\mathrm{Ph})\right]\right), 724\left(2,\left[M^{+}-1\right]\right)$.

$\mathrm{C}_{54} \mathrm{H}_{64} \mathrm{~N}_{2} \mathrm{Al}(\mathbf{2 0} \cdot 0.5 n$-hexane, 768.102): calcd. C 84.44, H 8.40, N 3.65; Found: C 84.81, H 8.42, N 3.61.

\section{$\mathrm{LAI}[\boldsymbol{\eta}-\mathrm{C}(\mathrm{H})=\mathrm{C}(\mathrm{H})-\boldsymbol{\eta}-](\mathrm{NN}=\mathrm{NAr})(\mathbf{2 1})$}

To a mixture of $18(0.25 \mathrm{~g}, 0.5 \mathrm{mmol})$ and $\mathrm{N}_{3} \mathrm{Ar}^{*}(0.18 \mathrm{~g}, 0.5 \mathrm{mmol})$ at $-50{ }^{\circ} \mathrm{C}$ toluene $(25$ $\mathrm{mL}$ ) was added. The suspension was stirred and allowed to warm to room temperature. After stirring for $12 \mathrm{~h}$, the removal of solvent and washing with $n$-hexane $(2 \mathrm{~mL})$ afforded 21 as orange crystalline solid. The X-ray quality single crystals of $\mathbf{2 1} \cdot 0.5 n$-hexane were grown from the $n$-hexane/toluene solution of 21 at $4{ }^{\circ} \mathrm{C}$ within $5 \mathrm{~d}$.

Yield: 0.37 g, 90\%. M.p. $215-216^{\circ} \mathrm{C}$.

${ }^{1} \mathrm{H}$ NMR (300.13 MHz, $\left.298 \mathrm{~K}, \mathrm{C}_{6} \mathrm{D}_{8}, \mathrm{ppm}\right): \delta=1.02\left(\mathrm{~d},{ }^{3} J_{\mathrm{HH}}=6.8 \mathrm{~Hz}, 2\right.$ x $\left.3 \mathrm{H}, \mathrm{CH}\left(\mathrm{CH}_{3}\right)_{2}\right)$, $1.05\left(\mathrm{~d},{ }^{3} J_{\mathrm{HH}}=6.8 \mathrm{~Hz}, 2 \times 3 \mathrm{H}, \mathrm{CH}\left(\mathrm{CH}_{3}\right)_{2}\right), 1.16\left(\mathrm{~d}^{3} J_{\mathrm{HH}}=6.8 \mathrm{~Hz}, 4 \times 3 \mathrm{H}, \mathrm{CH}\left(\mathrm{CH}_{3}\right)_{2}\right), 1.50$ $\left(\mathrm{s}, 2 \times 3 \mathrm{H}, \beta-\mathrm{CH}_{3}\right), 2.23(\mathrm{~s}, 2 \times 3 \mathrm{H}), 2.27$ (s, 4 × $\left.3 \mathrm{H}\right)\left(M e\left(\right.\right.$ in $\mathrm{Ar}$ ') ), 2.83 (sept, ${ }^{3} J_{\mathrm{HH}}=6.8 \mathrm{~Hz}$, $\left.2 \times 1 \mathrm{H}, \mathrm{CH}\left(\mathrm{CH}_{3}\right)_{2}\right), 3.03\left(\mathrm{sept},{ }^{3} J_{\mathrm{HH}}=6.8 \mathrm{~Hz}, 2 \times 1 \mathrm{H}, \mathrm{CH}\left(\mathrm{CH}_{3}\right)_{2}\right), 4.92(\mathrm{~s}, 1 \mathrm{H}, \gamma-\mathrm{CH}), 5.03$ 
$\left(\mathrm{d},{ }^{3} J_{\mathrm{HH}(\mathrm{cis})}=7.6 \mathrm{~Hz}, 1 \mathrm{H}\right), 7.51\left(\mathrm{~d},{ }^{3} J_{\mathrm{HH}(\mathrm{cis})}=7.6 \mathrm{~Hz}, 1 \mathrm{H}\right)(H \mathrm{C}=\mathrm{CH}), 6.83,6.97-7.12(\mathrm{~m})$, 7.15 (14 H, Ar-H, Ar*-H, Ar'-H).

${ }^{13} \mathrm{C}$ NMR (75.47 HMz, $\left.298 \mathrm{~K}, \mathrm{C}_{6} \mathrm{D}_{6}, \mathrm{ppm}\right): \delta=21.3,22.3,23.0,23.2,24.4,24.7,25.0,25.8$, 26.7, 29.1, $31.9\left(\mathrm{CH}\left(\mathrm{CH}_{3}\right)_{2}, \beta-\mathrm{CH}_{3}, \mathrm{Me}\left(\mathrm{Ar}{ }^{\prime}\right)\right), 100.5(\gamma-C), 114.8$ (broad, $\left.\mathrm{Al}-\mathrm{C}=\right)$, 123.5, 123.8, 125.1, 130.9, 134.2, 136.0, 138.5, 141.6, 146.2, $147.3\left(\mathrm{Ar}-C, \mathrm{Ar}^{*}-C, \mathrm{Ar}{ }^{\prime}-C\right), 162.4$ $(\mathrm{N}-C(\mathrm{H})=), 171.9(C \mathrm{~N})$.

MS (EI): m/z (\%) $417\left(100,\left[M^{+}-\mathrm{N}_{3} \mathrm{Ar}^{*}-\mathrm{C}_{2} \mathrm{H}_{2}-\mathrm{Al}\right]\right), 825\left(5,\left[M^{+}-1\right]\right)$.

$\mathrm{C}_{55} \mathrm{H}_{68} \mathrm{AlN}_{5}$ (826.17): calcd. C 79.96, H 8.30, N 8.48; Found: C 79.28, H 8.38, N 8.42.

\section{$\mathrm{LAI}\left[\mathrm{OC}(\mathrm{O}) \mathrm{C}_{2}(\mathrm{Ph})_{2}\right](22)$}

A toluene solution $(30 \mathrm{~mL})$ of $\mathrm{LAl}\left[\eta^{2}-\mathrm{C}_{2}(\mathrm{Ph})_{2}\right](0.62 \mathrm{~g}, 1 \mathrm{mmol})$ was exposed to predried $\mathrm{CO}_{2}$ and stirred for $12 \mathrm{~h}$. After workup, all volatiles were removed in vacuum and the residue was washed with $n$-hexane $(10 \mathrm{~mL})$ to give a colorless solid of 22.

Yield: 0.47 g, $70 \%$. M.p. $341-343^{\circ} \mathrm{C}$ (decomp.).

${ }^{1} \mathrm{H}$ NMR (300.13 MHz, $\left.298 \mathrm{~K}, \mathrm{C}_{6} \mathrm{D}_{6}, \mathrm{ppm}\right): \delta=0.82\left(\mathrm{~d},{ }^{3} J_{\mathrm{HH}}=6.7 \mathrm{~Hz}, 2\right.$ × $\left.3 \mathrm{H}, \mathrm{CH}\left(\mathrm{CH}_{3}\right)_{2}\right)$, $0.93\left(\mathrm{~d},{ }^{3} J_{\mathrm{HH}}=6.7 \mathrm{~Hz}, 2 \times 3 \mathrm{H}, \mathrm{CH}\left(\mathrm{CH}_{3}\right)_{2}\right), 1.10\left(\mathrm{~d},{ }^{3} J_{\mathrm{HH}}=6.7 \mathrm{~Hz}, 2 \times 3 \mathrm{H}, \mathrm{CH}\left(\mathrm{CH}_{3}\right)_{2}\right), 1.52$ $\left(\mathrm{d},{ }^{3} J_{\mathrm{HH}}=6.7 \mathrm{~Hz}, 2 \times 3 \mathrm{H}, \mathrm{CH}\left(\mathrm{CH}_{3}\right)_{2}\right), 1.53\left(\mathrm{~s}, 2 \times 3 \mathrm{H}, \beta-\mathrm{CH}_{3}\right), 2.90\left(\mathrm{sept},{ }^{3} J_{\mathrm{HH}}=6.7 \mathrm{~Hz}, 2 \mathrm{x}\right.$ $\left.1 \mathrm{H}, \mathrm{CH}\left(\mathrm{CH}_{3}\right)_{2}\right), 3.60\left(\mathrm{sept},{ }^{3} \mathrm{~J}_{\mathrm{HH}}=6.7 \mathrm{~Hz}, 2 \mathrm{x} 1 \mathrm{H}, \mathrm{CH}\left(\mathrm{CH}_{3}\right)_{2}\right), 5.00(\mathrm{~s}, 1 \mathrm{H}, \gamma-\mathrm{CH})$, 6.26-6.28 (m), 6.78-7.20 (m) (16 H, Ar-H and Ph-H).

${ }^{13} \mathrm{C}\left\{{ }^{1} \mathrm{H}\right\}$ NMR $\left(125.77 \mathrm{HMz}, 298 \mathrm{~K}, \mathrm{C}_{6} \mathrm{D}_{6}, \mathrm{ppm}\right): \delta=20.7,23.3,23.6,28.6\left(C \mathrm{CH}\left(\mathrm{CH}_{3}\right)_{2}, \beta-\right.$ $\left.\mathrm{CH}_{3}\right), 94.2(\gamma-C), 123.6,125.8,127.7,128.2,129.3,141.2,142.8,143.0,145.8(\mathrm{Ar}-C, \mathrm{Ph}-C$, $\mathrm{AlC}(\mathrm{Ph})=C(\mathrm{Ph})), 143.4(\mathrm{Al}-C), 161.5(C=\mathrm{O}), 172.8(C \mathrm{~N})$.

MS (EI): m/z (\%) $666.3\left(\left[M^{+}\right], 15\right), 651.3\left(\left[M^{+}-\mathrm{Me}\right], 100\right)$.

$\mathrm{C}_{44} \mathrm{H}_{51} \mathrm{AlN}_{2} \mathrm{O}_{2}$ (666.89): calcd. C 79.25, H 7.71, N 4.20; Found: C 78.92, H 7.54, N 4.26.

\section{LAI $\left[\mathrm{OC}(\mathrm{O}) \mathrm{C}_{2}\left(\mathrm{SiMe}_{3}\right)_{2}\right](23)$}

Compound $\mathbf{2 3}$ was prepared in a similar manner as that of $\mathbf{2 2}$. The spectral data are recoreded in reference 155 . The X-ray quality crystals of $\mathbf{2 3}$ were obtained by crystallizing the crude product from a mixture of solvents (toluene $:$ ether $: n$-hexane $=0.2: 1: 1$ ).

\section{$\operatorname{LAl}(\mu-S)\left(\eta-S C\left(\operatorname{SiMe}_{3}\right)=C=C\left(\operatorname{SiMe}_{3}\right)-\eta-\right)$ AlL (24)}

Neat carbon disulfide $(0.038 \mathrm{~g}, 0.5 \mathrm{mmol})$ was added to a solution of $\operatorname{LAl}\left[\eta^{2}-\mathrm{C}_{2}\left(\mathrm{SiMe}_{3}\right)_{2}\right]$ $(0.62 \mathrm{~g}, 1 \mathrm{mmol})$ in toluene $(20 \mathrm{~mL})$ at $-78^{\circ} \mathrm{C}$. In the course of warming to room temperature, the color of the reaction mixture changed from red-black to green, to yellow green, and finally 
to yellow. After additional stirring for $12 \mathrm{~h}$, all volatiles were removed under vacuum and the residue was washed with $n$-hexane $(20 \mathrm{~mL})$ to give a yellow solid. The yellow solid was dissolved in a hot mixture of solvents ( 2 toluene : 1 ether) $(15 \mathrm{~mL})$ and then kept at r.t. for 72 $\mathrm{h}$ to afford X-ray suitable single crystals of $\mathbf{2 4} \cdot 0.55$ toluene $\cdot 0.45$ ether.

Yield: 0.35 g, $57 \%$. M.p. $281-283{ }^{\circ} \mathrm{C}$.

${ }^{1} \mathrm{H}\left\{{ }^{13} \mathrm{C}\right\}$ NMR ([D $]$ toluene, $\left.500.13 \mathrm{MHz}, 300 \mathrm{~K}, \mathrm{ppm}\right): \delta=0.39,0.47(\mathrm{~s}, 2 \times 9 \mathrm{H}, \mathrm{SiMe})$, $0.88,0.70,0.83,0.68,1.19,0.58,1.39,1.15,1.31,1.08\left(\mathrm{~d},{ }^{3} J_{\mathrm{HH}}=6.7 \mathrm{~Hz}, 10 \times 3 \mathrm{H}, \mathrm{CH} M e_{2}\right)$, $1.15\left(\mathrm{t},{ }^{3} J_{\mathrm{HH}}=6.9 \mathrm{~Hz}, 2.70 \mathrm{H},\left(\mathrm{CH}_{3} \mathrm{CH}_{2}\right)_{2} \mathrm{O}\right), 1.25,0.54,1.33,1.05\left(\mathrm{~d},{ }^{3} J_{\mathrm{HH}}=6.8 \mathrm{~Hz}, 4 \times 3 \mathrm{H}\right.$, $\left.\mathrm{CHMe} e_{2}\right), 1.14,1.68\left(\mathrm{~d},{ }^{3} J_{\mathrm{HH}}=6.5 \mathrm{~Hz}, 2 \times 3 \mathrm{H}, \mathrm{CHMe} e_{2}\right), 1.48,1.41,1.40,1.37(\mathrm{~s}, 4 \times 3 \mathrm{H}, \beta-$ $\left.\mathrm{CH}_{3}\right), 2.10(\mathrm{~s}, 1.65 \mathrm{H}, \mathrm{MePh}), 3.17,3.17,3.10,2.96,2.93\left(\mathrm{sept},{ }^{3} \mathrm{~J}_{\mathrm{HH}}=6.7 \mathrm{~Hz}, 5 \times 1 \mathrm{H}\right.$, $\mathrm{CHMe}_{2}$ ), $3.13\left(\mathrm{sept},{ }^{3} \mathrm{~J}_{\mathrm{HH}}=6.5 \mathrm{~Hz}, 1 \mathrm{H}, \mathrm{CHMe}\right.$ ), 3.26 (quartet, ${ }^{3} J_{\mathrm{HH}}=6.9 \mathrm{~Hz}, 1.80 \mathrm{H}$, $\left.\left(\mathrm{CH}_{3} \mathrm{CH}_{2}\right)_{2} \mathrm{O}\right), 3.29,2.98\left(\mathrm{sept},{ }^{3} J_{\mathrm{HH}}=6.8 \mathrm{~Hz}, 2 \times 1 \mathrm{H}, \mathrm{CHMe} 2\right), 4.95,4.96(\mathrm{~s}, 2 \times 1 \mathrm{H}, \gamma-\mathrm{CH})$, 6.82-7.21 (m, $12 \mathrm{H}, \mathrm{Ar}-H)$.

${ }^{13} \mathrm{C} \mathrm{NMR}\left(\mathrm{CDCl}_{3}, 500.13 \mathrm{MHz}, 300 \mathrm{~K}, \mathrm{ppm}\right): \delta=212.70(\mathrm{C}=C=\mathrm{C}), 171.16,170.66,170.32$, $168.54(C \mathrm{~N}), 145.30,145.16,144.69,144.29,144.09,143.72,142.91,142.50,142.49,142.42$ $141.46,141.03,126.58,126.44,126.10,125.98,124.84,124.50,124.42$, 124.34, 124.27, 124.00, 123.95, 123.02 (Ar-C), 137.88, 129.04, 128.23, $125.30(\mathrm{Me} P h), 100.18,99.74$ ( $\gamma-C$ ), 80.60 (broad, $\mathrm{Al}-\mathrm{C}=\mathrm{C}=\mathrm{CS}), 65.84\left(\left(\mathrm{CH}_{3} \mathrm{CH}_{2}\right)_{2} \mathrm{O}\right), 59.94 \quad(\mathrm{C}=\mathrm{C}=\mathrm{CS}), 30.04,29.19,28.73$, $28.26,28.20,27.98,27.81,27.74,27.57,27.17,25.93,25.86,25.69,25.52,25.35,25.19$, 25.05, 24.95, 24.94, 24.82, 24.81, 24.71, 24.54, 24.51, 24.39, 24.36, 23.71, $23.22\left(\mathrm{CHMe}_{2}\right.$, $\mathrm{CHMe} 2$ and $\left.\beta-\mathrm{CH}_{3}\right), 21.45(\mathrm{MePh}), 15.27\left(\left(\mathrm{CH}_{3} \mathrm{CH}_{2}\right)_{2} \mathrm{O}\right), 2.19,0.89\left(\mathrm{SiMe}_{3}\right)$.

${ }^{29} \mathrm{Si} \mathrm{NMR}\left(\mathrm{C}_{6} \mathrm{D}_{6}, 500.13 \mathrm{MHz}, 300 \mathrm{~K}, \mathrm{ppm}\right): \delta=-5.51,-4.62\left(\mathrm{SiMe}_{3}\right)$.

IR ( $\mathrm{KBr}$ plate, Nujol mull, $\left.\mathrm{cm}^{-1}\right): \widetilde{v}=1822(\mathrm{C}=\mathrm{C}=\mathrm{C})$.

$\operatorname{MS} \quad(\mathrm{EI}): \quad m / z \quad(\%): 1135 \quad\left(60, \quad\left[M^{+}\right]\right) ; \quad 460 \quad\left(100, \quad\left[M^{+}-\left\{\mathrm{HC}(\mathrm{CMeNAr})_{2}\right\} \mathrm{Al} \quad-\right.\right.$ $\left.\mathrm{SC}\left(\mathrm{SiMe}_{3}\right)=\mathrm{C}=\mathrm{C}\left(\mathrm{SiMe}_{3}\right)-\mathrm{Me}-\mathrm{H}\right]$.

$\mathrm{C}_{72.65} \mathrm{H}_{108.90} \mathrm{Al}_{2} \mathrm{~N}_{4} \mathrm{O}_{0.45} \mathrm{~S}_{2} \mathrm{Si}_{2}$ (24·0.55toluene-0.45ether, 1219.82): calcd. C 71.53, H 9.00, $\mathrm{N}$ 4.59; Found: C 71.29, H 9.09, N 4.69.

LAI $\left[N-\mathrm{C}_{6} \mathrm{H}_{3}-2-\left(2,6-i \mathrm{Pr}_{2} \mathrm{C}_{6} \mathrm{H}_{3}\right)-6-\left(2,6-i \mathrm{Pr}_{2} \mathrm{C}_{6} \mathrm{H}_{3}\right)\right]$

(25) and

$\left\{\mathrm{HC}[(\mathrm{CMe})(\mathrm{NAr})]\left[(\mathrm{CMe})\left(\mathrm{N}-\mathrm{C}_{6} \mathrm{H}_{3}-2-i \operatorname{Pr}-6-\mathrm{CH}\left(\mathrm{CH}_{2}\right)(\mathrm{Me})\right]\right\} \mathrm{Al}(\mathrm{NHAr})\right.$ (26)

Pre-cooled toluene $(25 \mathrm{~mL})$ was added to a mixture of LAl $(0.25 \mathrm{~g}, 0.56 \mathrm{mmol})$ and $\mathrm{N}_{3} \mathrm{Ar}$ ' $(0.25 \mathrm{~g}, 0.56 \mathrm{mmol})$ at $-78{ }^{\circ} \mathrm{C}$. The mixture was allowed to warm to room temperature and 
stirred for $12 \mathrm{~h}$. The light yellow solution was concentrated ( $5 \mathrm{~mL})$, and to it $n$-hexane (10 $\mathrm{mL}$ ) was added. The solution was kept at $4{ }^{\circ} \mathrm{C}$ for three weeks to afford colorless crystals of 26.

Yield: 0.12 g (24\%). M.p. $381-383^{\circ} \mathrm{C}$ (>320 ${ }^{\circ} \mathrm{C}$, decomp.).

${ }^{1} \mathrm{H}$ NMR (500.13 MHz, $\left.\mathrm{C}_{6} \mathrm{D}_{6}, 298 \mathrm{~K}, \mathrm{ppm}\right): \delta=-1.75\left(\mathrm{t}, 1 \mathrm{H},{ }^{2} J_{\mathrm{HH}}=-13.8 \mathrm{~Hz},{ }^{3} J_{\mathrm{HH}}=13.8\right.$ $\left.\mathrm{Hz}, \mathrm{Al}-\mathrm{CH}_{2}\right),-0.28\left(\mathrm{dd}, 1 \mathrm{H},{ }^{2} J_{\mathrm{HH}}=13.8 \mathrm{~Hz},{ }^{3} J_{\mathrm{HH}}=3.0 \mathrm{~Hz}, \mathrm{Al}-\mathrm{CH}_{2}\right), 0.36,0.39,0.50,0.80$, $1.15,1.22,1.30\left(\mathrm{~d}, 7 \times 3 \mathrm{H},{ }^{3} J_{\mathrm{HH}}=6.8 \mathrm{~Hz}, \mathrm{CH}\left(\mathrm{CH}_{3}\right)_{2}\right), 0.93,0.94,1.08,1.11\left(\mathrm{~d}, 4 \times 3 \mathrm{H},{ }^{3} J_{\mathrm{HH}}\right.$ $\left.=6.7 \mathrm{~Hz}, \mathrm{CH}\left(\mathrm{CH}_{3}\right)_{2}\right), 1.25,1.34\left(\mathrm{~d}, 2 \times 3 \mathrm{H},{ }^{3} \mathrm{~J}_{\mathrm{HH}}=6.6 \mathrm{~Hz}, \mathrm{CH}\left(\mathrm{CH}_{3}\right)_{2}\right), 1.31,1.53(\mathrm{~d}, 2 \times 3 \mathrm{H}$, $\left.{ }^{3} J_{\mathrm{HH}}=6.9 \mathrm{~Hz}, \mathrm{CH}\left(\mathrm{CH}_{3}\right)_{2}\right), 1.45,1.50\left(\mathrm{~s}, 2 \times 3 \mathrm{H}, \beta-\mathrm{CH}_{3}\right), 2.30\left(\mathrm{sept}, 1 \mathrm{H},{ }^{3} J_{\mathrm{HH}}=6.9 \mathrm{~Hz}\right.$, $\left.\mathrm{CH}\left(\mathrm{CH}_{3}\right)_{2}\right), 2.41,2.80,3.47$ (sept, $\left.3 \times 1 \mathrm{H},{ }^{3} \mathrm{~J}_{\mathrm{HH}}=6.8 \mathrm{~Hz}, \mathrm{CH}\left(\mathrm{CH}_{3}\right)_{2}\right), 2.99,3.39$ (sept, $2 \times 1$ $\left.\mathrm{H},{ }^{3} J_{\mathrm{HH}}=6.7 \mathrm{~Hz}, \mathrm{CH}\left(\mathrm{CH}_{3}\right)_{2}\right), 3.07$ (sept, $\left.1 \mathrm{H},{ }^{3} J_{\mathrm{HH}}=6.6 \mathrm{~Hz}, \mathrm{CH}\left(\mathrm{CH}_{3}\right)_{2}\right), 2.56(\mathrm{~m}, 1 \mathrm{H}$, $\left.\mathrm{CH}\left(\mathrm{CH}_{3}\right)\left(\mathrm{CH}_{2}\right)\right), 3.41$ (s, $\left.1 \mathrm{H}, \mathrm{NH}\right), 4.82(\mathrm{~s}, 1 \mathrm{H}, \gamma-\mathrm{CH}), 6.65(\mathrm{~m}, 1 \mathrm{H}, \mathrm{Ph}-H), 6.92-7.00$ (m, 3 x $1 \mathrm{H}, \mathrm{Ph}-H), 7.04-7.20(\mathrm{~m}, 6$ x $1 \mathrm{H}, \mathrm{Ph}-H), 7.20-7.32$ (m, 4 x $1 \mathrm{H}, \mathrm{Ph}-H), 7.34-7.38$ (m, 1 $\mathrm{H}, \mathrm{Ph}-H)$.

${ }^{13} \mathrm{C}$ NMR (125.76 MHz, $\left.\mathrm{C}_{6} \mathrm{D}_{6}, 298 \mathrm{~K}, \mathrm{ppm}\right): \delta=18.50$ (br, Al-C), 21.64, 21.68, 22.10, 22.84, $22.98,23.61,23.83,23.93,24.41,25.31,25.45,25.55,26.31,26.92,26.98,27.06,27.25$, 27.66, 28.53, 28.57, 29.97, 30.03, 31.23, 31.69, $34.04\left(\beta-\mathrm{CH}_{3}, \mathrm{CH}\left(\mathrm{CH}_{3}\right)_{2}, C \mathrm{CH}\left(\mathrm{CH}_{3}\right)\left(\mathrm{CH}_{2}\right)\right)$, $98.99(\gamma-\mathrm{CH}), 114.62,122.23,122.98,123.08,123.64,124.65,124.67,125.06,125.65$, $125.93,126.55,126.88,127.81,127.92,128.42,131.23,133.84,138.21,140.30,141.50$, $142.48,143.51,143.82,145.58,146.53,147.62,148.48,148.53,150.68,150.94(\mathrm{Ph}-C)$, 169.40, $169.52(C \mathrm{~N})$.

IR (KBr plate, Nujol mull, $\left.\mathrm{cm}^{-1}\right): v=3298(\mathrm{NH})$.

MS (EI): $m / z(\%): 855\left(10,\left[M^{+}-1\right]\right) ; 443\left(100,\left[M^{+}-\mathrm{NHAr}\right]\right.$.

$\mathrm{C}_{59} \mathrm{H}_{78} \mathrm{AlN}_{3}$ (855.42): calcd. C 82.76, H 9.18, N 4.91. Found: C 82.60, H 9.28, N 4.98.

After the collection of crystals of $\mathbf{2 6}$, the mother liquor was kept at $4{ }^{\circ} \mathrm{C}$ for additional three weeks. A crop of yellowish crystals of $\mathbf{2 5}$ were obtained and collected by filtration. Compound 25 has a similar decomposition temperature and melting point as those of $\mathbf{2 6}$. Its EI mass spectroscopic data is also similar to that of $\mathbf{2 6 .}$

Yield: $0.21 \mathrm{~g}(42 \%)$.

${ }^{1} \mathrm{H}$ NMR (500.13 MHz, $\left.\mathrm{C}_{6} \mathrm{D}_{6}, 298 \mathrm{~K}, \mathrm{ppm}\right): \delta=0.26,0.53,0.54,1.46\left(\mathrm{~d}, 4 \times 3 \mathrm{H},{ }^{3} J_{\mathrm{HH}}=6.8\right.$ $\left.\mathrm{Hz}, \mathrm{CH}\left(\mathrm{CH}_{3}\right)_{2}\right), 0.81,0.93,1.01,1.06,1.11,1.30\left(\mathrm{~d}, 6 \times 3 \mathrm{H},{ }^{3} J_{\mathrm{HH}}=6.7 \mathrm{~Hz}, \mathrm{CH}\left(\mathrm{CH}_{3}\right)_{2}\right), 0.86$, $0.88,1.14,1.27,1.39,1.42\left(\mathrm{~d}, 6 \times 3 \mathrm{H},{ }^{3} \mathrm{~J}_{\mathrm{HH}}=6.9 \mathrm{~Hz}, \mathrm{CH}\left(\mathrm{CH}_{3}\right)_{2}\right), 1.30,1.40(\mathrm{~s}, 2 \times 3 \mathrm{H}, \beta-$ $\left.\mathrm{CH}_{3}\right), 2.34,3.33$ (sept, $\left.2 \times 1 \mathrm{H},{ }^{3} J_{\mathrm{HH}}=6.8 \mathrm{~Hz}, \mathrm{CH}\left(\mathrm{CH}_{3}\right)_{2}\right), 2.64,3.02,3.18$ (sept, 3 x $1 \mathrm{H},{ }^{3} J_{\mathrm{HH}}$ $\left.=6.7 \mathrm{~Hz}, \mathrm{CH}\left(\mathrm{CH}_{3}\right)_{2}\right), 3.12,3.33,3.33\left(\mathrm{sept}, 3 \times 1 \mathrm{H},{ }^{3} J_{\mathrm{HH}}=6.9 \mathrm{~Hz}, \mathrm{CH}\left(\mathrm{CH}_{3}\right)_{2}\right), 2.43(\mathrm{~d}, 1 \mathrm{H}$, 
$\left.{ }^{3} J_{\mathrm{HH}}=6.4 \mathrm{~Hz}, \mathrm{Al}-\mathrm{CH}\right), 4.88(\mathrm{~s}, 1 \mathrm{H}, \gamma-\mathrm{CH}), 5.41\left(\mathrm{~d}, 1 \mathrm{H},{ }^{3} J_{\mathrm{HH}}=9.4 \mathrm{~Hz}, \mathrm{AlCH}-\mathrm{CH}\right), 6.08$ $\left(\mathrm{dd}, 1 \mathrm{H},{ }^{3} J_{\mathrm{HH}}=6.4 \mathrm{~Hz},{ }^{3} J_{\mathrm{HH}}=9.4 \mathrm{~Hz}, \mathrm{AlCH}-\mathrm{CH}=\mathrm{CH}\right), 6.86(\mathrm{~m}, 2 \times 1 \mathrm{H}, \mathrm{Ph}-H), 6.92(\mathrm{~m}, 1$ $\mathrm{H}, \mathrm{Ph}-H), 6.99(\mathrm{~m}, 1 \mathrm{H}, \mathrm{Ph}-H), 7.04-7.12(\mathrm{~m}, 4 \mathrm{x} 1 \mathrm{H}, \mathrm{Ph}-H), 7.28(\mathrm{~m}, 2 \times 1 \mathrm{H}, \mathrm{Ph}-H), 7.37$ (m, $1 \mathrm{H}, \mathrm{Ph}-H), 7.49(\mathrm{~m}, 1 \mathrm{H}, \mathrm{Ph}-H)$.

${ }^{13} \mathrm{C}$ NMR (125.76 MHz, $\left.\mathrm{C}_{6} \mathrm{D}_{6}, 298 \mathrm{~K}, \mathrm{ppm}\right): \delta=14.28,15.64,18.58,20.40,22.99,23.46$, $23.75,24.36,24.47,24.72,24.72,24.84,24.84,24.89,24.96,25.00,25.49,25.63,26.31$, 26.60, 27.40, 28.22, 29.00, 29.10, 29.84, 32.50, $26.93\left(\beta-\mathrm{CH}_{3}, \mathrm{CH}\left(\mathrm{CH}_{3}\right)_{2}, \mathrm{CH}\left(\mathrm{CH}_{3}\right)_{2}\right.$, $\mathrm{NC}(i \mathrm{Pr}), 73.99(\mathrm{Al}-C), 100.93(\gamma-C \mathrm{H}), 113.08,118.25,121.76,123.88,124.19,124.21$, 124.52 , 124.56, 125.22, 127.05, 127.70, 128.00, 128.10, 128.20, 130.33, 132.06, 134.52, $136.42,137.18,141.52,141.95,143.21,143.58,145.54,146.09,146.79,149.47,153.54$ $(\mathrm{Ph}-C, C \mathrm{H}=C \mathrm{H}-C(i \mathrm{Pr})=C), 170.21(C \mathrm{~N})$.

Correct elemental analysis. Attempts to recrystallize the yellow crystalline material of 25 by dissolving it in a hot toluene/ $n$-hexane mixture resulted in the formation of colorless solution which was kept at $4{ }^{\circ} \mathrm{C}$ for crystallization. Colorless rectangular crystals were obtained and were found by spectroscopic and X-ray crystallographic evidence to be $\mathbf{2 6}$. 


\subsection{Handing and Disposal of Solvents and Residual Waste}

1. The recovered solvents were distilled or condensed into cold-traps under vacuum, collected in halogen-free or halogen-containing solvent containers, and stored for disposal.

2. Used NMR solvents were classified into halogen-free or halogen-containing solvents and were disposed as heavy metal wastes and halogen-containing wastes, respectively.

3. The heavy metal residues were dissolved in nitric acid and after neutralization stored in the container for heavy metal wastes.

4. Drying agents such as $\mathrm{KOH}, \mathrm{CaCl}_{2}, \mathrm{MgCl}_{2}, \mathrm{MgSO}_{4}$, and $\mathrm{P}_{4} \mathrm{O}_{10}$ were hydrolyzed and disposed as acid or base wastes.

5. Wherever possible, sodium metal used for drying solvents was collected for recycling. The non-reusable sodium metal was carefully treated with cold ethanol and potassium in cold isopropanol and collected into the base-bath cleaning glassware.

6. Ethanol and acetone used for cooling baths were subsequently used for cleaning glassware.

7. The acid bath for cleaning glassware was neutralized with $\mathrm{Na}_{2} \mathrm{CO}_{3}$ and the resulting $\mathrm{NaCl}$ solution was washed off in the water drainage system.

8. The residual of the base both for cleaning glassware was poured into the container for base wastes.

Amount of various types of disposable wastes generated during the work.

$\begin{array}{lc}\text { Metal containing wastes } & 5 \mathrm{~L} \\ \text { Halogen-containing wastes } & 4 \mathrm{~L} \\ \text { Halogen-free solvent wastes } & 40 \mathrm{~L} \\ \text { Acid wastes } & 12 \mathrm{~L} \\ \text { Base wastes } & 12 \mathrm{~L}\end{array}$




\subsection{Crystal Data and Refinement Details}

\begin{tabular}{|c|c|c|}
\hline Compounds & 1.0.5 n-hexane & 2 \\
\hline Formula & $\mathrm{C}_{33} \mathrm{H}_{57} \mathrm{AlN}_{3}$ & $\mathrm{C}_{30} \mathrm{H}_{49} \mathrm{AlFN}_{3}$ \\
\hline $\mathrm{Fw}$ & 522.80 & 497.70 \\
\hline temp $(\mathrm{K})$ & 203(2) & $200(2)$ \\
\hline crystal syst & monoclinic & monoclinic \\
\hline space group & $P 2(1) / n$ & $P 2(1) / n$ \\
\hline$a(\AA)$ & $12.285(3)$ & $13.323(6)$ \\
\hline$b(\AA)$ & $20.125(4)$ & $12.480(2)$ \\
\hline$c(\AA)$ & $14.274(3)$ & $17.979(5)$ \\
\hline \multicolumn{3}{|l|}{$\alpha(\operatorname{deg})$} \\
\hline$\beta(\operatorname{deg})$ & $110.47(3)$ & $92.57(5)$ \\
\hline \multicolumn{3}{|l|}{$\gamma(\operatorname{deg})$} \\
\hline$V\left(\AA^{3}\right)$ & $3306(1)$ & 2987(2) \\
\hline $\mathrm{Z}$ & 4 & 4 \\
\hline$\rho_{c}\left(\mathrm{Mg} / \mathrm{m}^{3}\right)$ & 1.050 & 1.107 \\
\hline$\mu\left(\mathrm{mm}^{-1}\right)$ & 0.085 & 0.096 \\
\hline$F(000)$ & 1156 & 1088 \\
\hline$\theta$ range (deg) & $3.52-25.00$ & $3.61-25.04$ \\
\hline \multirow[t]{3}{*}{ Index ranges } & $-14 \leq h \leq 14$ & $-15 \leq h \leq 15$ \\
\hline & $-23 \leq k \leq 23$ & $-10 \leq k \leq 14$ \\
\hline & $-16 \leq l \leq 16$ & $-16 \leq l \leq 21$ \\
\hline no. of reflns collected & 11566 & 5643 \\
\hline no. of indep reflns $\left(R_{\text {int }}\right)$ & $5786(0.0346)$ & $5249(0.1332)$ \\
\hline no. of data/restraints/params & $5786 / 0 / 350$ & $5249 / 0 / 327$ \\
\hline$G o F / F^{2}$ & 1.004 & 1.069 \\
\hline$R 1^{\mathrm{a}}, w R 2^{\mathrm{b}}(I>2 \sigma(I))$ & $0.0418,0.0994$ & $0.0486,0.1282$ \\
\hline$R 1^{\mathrm{a}}, w R 2^{\mathrm{b}}$ (all data) & $0.0586,0.1101$ & $0.0532,0.1340$ \\
\hline largest diff peak/hole $\left(\mathrm{e} \cdot \AA^{-3}\right)$ & $0.200 /-0.228$ & $0.519 /-0.300$ \\
\hline
\end{tabular}




\begin{tabular}{|c|c|c|}
\hline Compounds & $4 \cdot 2$ toluene & 7 \\
\hline Formula & $\mathrm{C}_{68} \mathrm{H}_{96} \mathrm{AlN}_{4} \mathrm{Se}_{2}$ & $\mathrm{C}_{29} \mathrm{H}_{41} \mathrm{AlClIN}_{2}$ \\
\hline Fw & 1181.37 & 606.97 \\
\hline temp $(\mathrm{K})$ & $133(2)$ & $133(2)$ \\
\hline crystal syst & monoclinic & monoclinic \\
\hline space group & $C 2$ & $P 2(1) / n$ \\
\hline$a(\AA)$ & $19.104(4)$ & $12.594(1)$ \\
\hline$b(\AA)$ & $17.561(4)$ & $19.493(1)$ \\
\hline$c(\AA)$ & $12.286(3)$ & $13.502(1)$ \\
\hline \multicolumn{3}{|l|}{$\alpha(\operatorname{deg})$} \\
\hline$\beta(\operatorname{deg})$ & $129.10(3)$ & $116.47(1)$ \\
\hline \multicolumn{3}{|l|}{$\gamma(\operatorname{deg})$} \\
\hline$V\left(\AA^{3}\right)$ & $3199(1)$ & $2967(1)$ \\
\hline $\mathrm{Z}$ & 2 & 4 \\
\hline$\rho_{c}\left(\mathrm{Mg} / \mathrm{m}^{3}\right)$ & 1.227 & 1.359 \\
\hline$\mu\left(\mathrm{mm}^{-1}\right)$ & 1.225 & 1.218 \\
\hline$F(000)$ & 1252 & 1248 \\
\hline$\theta$ range $(\mathrm{deg})$ & $1.80-24.81$ & $1.84-24.86$ \\
\hline \multirow[t]{3}{*}{ Index ranges } & $-22 \leq h \leq 22$ & $-14 \leq h \leq 14$ \\
\hline & $-20 \leq k \leq 20$ & $-22 \leq k \leq 22$ \\
\hline & $-14 \leq l \leq 13$ & $-15 \leq l \leq 15$ \\
\hline no. of reflns collected & 18430 & 28829 \\
\hline no. of indep reflns $\left(R_{\text {int }}\right)$ & $5488(0.0718)$ & $5005(0.0343)$ \\
\hline no. of data/restraints/params & $5488 / 1 / 312$ & $5005 / 0 / 317$ \\
\hline$G o F / F^{2}$ & 0.996 & 1.092 \\
\hline$R 1^{\mathrm{a}}, w R 2^{\mathrm{b}}(I>2 \sigma(I))$ & $0.0433,0.1112$ & $0.0322,0.0939$ \\
\hline$R 1^{\mathrm{a}}, w R 2^{\mathrm{b}}$ (all data) & $0.0529,0.1164$ & $0.0368,0.0959$ \\
\hline largest diff peak/hole $\left(\mathrm{e} \cdot \AA^{-3}\right)$ & $0.694 /-0.514$ & $0.853 /-0.935$ \\
\hline
\end{tabular}




\begin{tabular}{|c|c|c|}
\hline Compounds & $8 \cdot n$-hexane & $\mathbf{1 0}$ \\
\hline Formula & $\mathrm{C}_{64} \mathrm{H}_{98} \mathrm{Al}_{2} \mathrm{Cl}_{2} \mathrm{~N}_{2} \mathrm{O}_{2}$ & $\mathrm{C}_{58} \mathrm{H}_{82} \mathrm{Al}_{2} \mathrm{~N}_{4} \mathrm{O}_{2}$ \\
\hline Fw & 1080.32 & 921.24 \\
\hline temp $(\mathrm{K})$ & $133(2)$ & $100(2)$ \\
\hline crystal syst & monoclinic & monoclinic \\
\hline space group & $P 2(1) / c$ & $P 2(1) / n$ \\
\hline$a(\AA)$ & $13.567(2)$ & $13.652(3)$ \\
\hline$b(\AA)$ & $13.263(2)$ & $13.717(3)$ \\
\hline$c(\AA)$ & $17.359(5)$ & $14.166(3)$ \\
\hline \multicolumn{3}{|l|}{$\alpha(\operatorname{deg})$} \\
\hline$\beta(\operatorname{deg})$ & $103.76(2)$ & $106.89(3)$ \\
\hline \multicolumn{3}{|l|}{$\gamma(\operatorname{deg})$} \\
\hline$V\left(\AA^{3}\right)$ & $3034(1)$ & $2538(1)$ \\
\hline $\mathrm{Z}$ & 2 & 2 \\
\hline$\rho_{c}\left(\mathrm{Mg} / \mathrm{m}^{3}\right)$ & 1.183 & 1.205 \\
\hline$\mu\left(\mathrm{mm}^{-1}\right)$ & 0.182 & 0.867 \\
\hline$F(000)$ & 1172 & 1000 \\
\hline$\theta$ range $(\mathrm{deg})$ & $1.55-25.40$ & $0.99-58.95$ \\
\hline \multirow[t]{3}{*}{ Index ranges } & $-16 \leq h \leq 16$ & $-14 \leq h \leq 15$ \\
\hline & $-15 \leq k \leq 15$ & $-14 \leq k \leq 14$ \\
\hline & $-20 \leq l \leq 20$ & $-15 \leq l \leq 15$ \\
\hline no. of reflns collected & 46371 & 14090 \\
\hline no. of indep reflns $\left(R_{\text {int }}\right)$ & $5559(0.0802)$ & $3617(0.0295)$ \\
\hline no. of data/restraints/params & $5559 / 0 / 376$ & 3617 / $141 / 337$ \\
\hline$G o F / F^{2}$ & 0.923 & 1.049 \\
\hline$R 1^{\mathrm{a}}, w R 2^{\mathrm{b}}(I>2 \sigma(I))$ & $0.0338,0.0729$ & $0.0328,0.0851$ \\
\hline$R 1^{\mathrm{a}}, w R 2^{\mathrm{b}}$ (all data) & $0.0556,0.0782$ & $0.0364,0.878$ \\
\hline largest diff peak/hole $\left(\mathrm{e} \cdot \AA^{-3}\right)$ & $0.229 /-0.190$ & $0.330 /-0.257$ \\
\hline
\end{tabular}




\begin{tabular}{|c|c|c|}
\hline Compounds & 12.0.12 toluene $\cdot 0.05 n$-hexane & 13 \\
\hline Formula & $\mathrm{C}_{54.14} \mathrm{H}_{67.65} \mathrm{AlN}_{3}$ & $\mathrm{C}_{58} \mathrm{H}_{82} \mathrm{Al}_{2} \mathrm{~N}_{4} \mathrm{O}_{2}$ \\
\hline Fw & 787.44 & 921.24 \\
\hline temp $(\mathrm{K})$ & $100(2)$ & $100(2)$ \\
\hline crystal syst & monoclinic & monoclinic \\
\hline space group & $C 2 / c$ & $P 2 / c$ \\
\hline$a(\AA)$ & $21.560(4)$ & $22.605(4)$ \\
\hline$b(\AA)$ & $10.457(2)$ & $12.583(2)$ \\
\hline$c(\AA)$ & $48.816(8)$ & $19.132(3)$ \\
\hline \multicolumn{3}{|l|}{$\alpha(\mathrm{deg})$} \\
\hline$\beta(\operatorname{deg})$ & $97.26(3)$ & $102.68(2)$ \\
\hline \multicolumn{3}{|l|}{$\gamma(\operatorname{deg})$} \\
\hline$V\left(\AA^{3}\right)$ & $9128(3)$ & $5310(2)$ \\
\hline $\mathrm{Z}$ & 8 & 4 \\
\hline$\rho_{c}\left(\mathrm{Mg} / \mathrm{m}^{3}\right)$ & 1.146 & 1.153 \\
\hline$\mu\left(\mathrm{mm}^{-1}\right)$ & 0.670 & 0.829 \\
\hline$F(000)$ & 3412 & 2000 \\
\hline$\theta$ range (deg) & $2.18-59.07$ & $3.51-58.97$ \\
\hline \multirow[t]{3}{*}{ Index ranges } & $-23 \leq h \leq 23$ & $-23 \leq h \leq 24$ \\
\hline & $-11 \leq k \leq 11$ & $-13 \leq k \leq 13$ \\
\hline & $-45 \leq l \leq 43$ & $-21 \leq l \leq 20$ \\
\hline no. of reflns collected & 30396 & 28366 \\
\hline no. of indep reflns $\left(R_{\text {int }}\right)$ & $6498(0.0374)$ & $7554(0.0360)$ \\
\hline no. of data/restraints/params & 6498 / 126 / 624 & 7554 / 97 / 654 \\
\hline$G o F / F^{2}$ & 1.023 & 1.025 \\
\hline$R 1^{\mathrm{a}}, w R 2^{\mathrm{b}}(I>2 \sigma(I))$ & $0.0369,0.0859$ & $0.0344,0.0850$ \\
\hline$R 1^{\mathrm{a}}, w R 2^{\mathrm{b}}$ (all data) & $0.0463,0.0910$ & $0.0421,0.0895$ \\
\hline largest diff peak/hole $\left(\mathrm{e} \cdot \AA^{-3}\right)$ & $0.200 /-0.265$ & $0.213 /-0.240$ \\
\hline
\end{tabular}




\begin{tabular}{|c|c|c|}
\hline Compounds & 14 & 16 \\
\hline Formula & $\mathrm{C}_{40} \mathrm{H}_{61} \mathrm{AlN}_{4}$ & $\mathrm{C}_{55} \mathrm{H}_{61} \mathrm{AlN}_{4}$ \\
\hline Fw & 624.91 & 805.06 \\
\hline temp $(\mathrm{K})$ & $133(2)$ & $203(2)$ \\
\hline crystal syst & monoclinic & orthorombic \\
\hline space group & $P 2(1) / c$ & $P 2(1) 2(1) 2(1)$ \\
\hline$a(\AA)$ & $10.161(2)$ & $12.285(2)$ \\
\hline$b(\AA)$ & $17.380(4)$ & $12.981(2)$ \\
\hline$c(\AA)$ & $22.274(5)$ & $30.001(6)$ \\
\hline \multicolumn{3}{|l|}{$\alpha(\mathrm{deg})$} \\
\hline$\beta(\operatorname{deg})$ & $101.89(3)$ & \\
\hline \multicolumn{3}{|l|}{$\gamma(\operatorname{deg})$} \\
\hline$V\left(\AA^{3}\right)$ & $3849.1(13)$ & $4784.4(16)$ \\
\hline $\mathrm{Z}$ & 4 & 4 \\
\hline$\rho_{c}\left(\mathrm{Mg} / \mathrm{m}^{3}\right)$ & 1.078 & 1.118 \\
\hline$\mu\left(\mathrm{mm}^{-1}\right)$ & 0.084 & 0.082 \\
\hline$F(000)$ & 1386 & 1728 \\
\hline$\theta$ range (deg) & $1.87-24.71$ & $3.55-25.01$ \\
\hline \multirow[t]{3}{*}{ Index ranges } & $-11 \leq h \leq 11$ & $0 \leq h \leq 14$ \\
\hline & $-20 \leq k \leq 20$ & $-1 \leq k \leq 15$ \\
\hline & $-26 \leq l \leq 24$ & $-35 \leq l \leq 35$ \\
\hline no. of reflns collected & 33356 & 4675 \\
\hline no. of indep reflns $\left(R_{\text {int }}\right)$ & $6560(0.1511)$ & $4658(0.0188)$ \\
\hline no. of data/restraints/params & $6560 / 0 / 424$ & $4658 / 0 / 555$ \\
\hline$G o F / F^{2}$ & 0.911 & 1.096 \\
\hline$R 1^{\mathrm{a}}, w R 2^{\mathrm{b}}(I>2 \sigma(I))$ & $0.0541,0.0974$ & $0.0614,0.1530$ \\
\hline$R 1^{\mathrm{a}}, w R 2^{\mathrm{b}}$ (all data) & $0.1198,0.1096$ & $0.0848,0.1740$ \\
\hline largest diff peak/hole $\left(\mathrm{e} \cdot \AA^{-3}\right)$ & $0.313 /-0.271$ & $0.271 /-0.282$ \\
\hline
\end{tabular}




\begin{tabular}{|c|c|c|}
\hline Compounds & 17 & 18 \\
\hline Formula & $\mathrm{C}_{41} \mathrm{H}_{51} \mathrm{AlN}_{4}$ & $\mathrm{C}_{31} \mathrm{H}_{43} \mathrm{AlN}_{2}$ \\
\hline Fw & 626.84 & 470.65 \\
\hline temp $(\mathrm{K})$ & $133(2)$ & $133(2)$ \\
\hline crystal syst & triclinic & monoclinic \\
\hline space group & $P-1$ & $P 2(1) / n$ \\
\hline$a(\AA)$ & $11.704(3)$ & $12.199(1)$ \\
\hline$b(\AA)$ & $12.612(2)$ & $16.932(1)$ \\
\hline$c(\AA)$ & $12.980(4)$ & $13.974(1)$ \\
\hline$\alpha(\operatorname{deg})$ & $86.460(2)$ & \\
\hline$\beta(\operatorname{deg})$ & $77.11(2)$ & $103.87(1)$ \\
\hline$\gamma(\operatorname{deg})$ & $86.40(2)$ & \\
\hline$V\left(\AA^{3}\right)$ & $1861.7(7)$ & 2802(1) \\
\hline $\mathrm{Z}$ & 2 & 4 \\
\hline$\rho_{c}\left(\mathrm{Mg} / \mathrm{m}^{3}\right)$ & 1.118 & 1.116 \\
\hline$\mu\left(\mathrm{mm}^{-1}\right)$ & 0.087 & 0.093 \\
\hline$F(000)$ & 676 & 1024 \\
\hline$\theta$ range (deg) & $1.61-24.88$ & $1.92-24.83$ \\
\hline \multirow[t]{3}{*}{ Index ranges } & $-13 \leq h \leq 13$ & $-14 \leq h \leq 14$ \\
\hline & $-14 \leq k \leq 14$ & $-19 \leq k \leq 19$ \\
\hline & $-15 \leq l \leq 15$ & $-16 \leq l \leq 16$ \\
\hline no. of reflns collected & 27600 & 29105 \\
\hline no. of indep reflns $\left(R_{\text {int }}\right)$ & $6396(0.0536)$ & $4818(0.0486)$ \\
\hline no. of data/restraints/params & $6396 / 0 / 424$ & 4818 / 0 / 325 \\
\hline$G o F / F^{2}$ & 1.015 & 1.030 \\
\hline$R 1^{\mathrm{a}}, w R 2^{\mathrm{b}}(I>2 \sigma(I))$ & $0.0391,0.0915$ & $0.0349,0.0867$ \\
\hline$R 1^{\mathrm{a}}, w R 2^{\mathrm{b}}$ (all data) & $0.0539,0.0979$ & $0.0502,0.0916$ \\
\hline largest diff peak/hole $\left(\mathrm{e} \cdot \AA^{-3}\right)$ & $0.210 /-0.235$ & $0.263 /-0.255$ \\
\hline
\end{tabular}




\begin{tabular}{|c|c|c|}
\hline Compounds & 19 & 20.0.5n-hexane \\
\hline Formula & $\mathrm{C}_{33} \mathrm{H}_{45} \mathrm{AlN}_{2}$ & $\mathrm{C}_{54} \mathrm{H}_{64} \mathrm{AlN}_{2}$ \\
\hline Fw & 496.69 & 768.05 \\
\hline temp $(\mathrm{K})$ & $133(2)$ & $133(2)$ \\
\hline crystal syst & monoclinic & monoclinic \\
\hline space group & $P 2(1) / n$ & $P 2(1) / n$ \\
\hline$a(\AA)$ & $18.844(4)$ & $14.641(3)$ \\
\hline$b(\AA)$ & $8.732(2)$ & $19.674(4)$ \\
\hline$c(\AA)$ & $20.080(4)$ & $16.162(3)$ \\
\hline \multicolumn{3}{|l|}{$\alpha(\operatorname{deg})$} \\
\hline$\beta(\operatorname{deg})$ & $112.61(1)$ & $99.78(3)$ \\
\hline \multicolumn{3}{|l|}{$\gamma(\operatorname{deg})$} \\
\hline$V\left(\AA^{3}\right)$ & $3050(1)$ & $4588(2)$ \\
\hline $\mathrm{Z}$ & 4 & 4 \\
\hline$\rho_{c}\left(\mathrm{Mg} / \mathrm{m}^{3}\right)$ & 1.082 & 1.112 \\
\hline$\mu\left(\mathrm{mm}^{-1}\right)$ & 0.089 & 0.081 \\
\hline$F(000)$ & 1080 & 1660 \\
\hline$\theta$ range (deg) & $1.89-24.82$ & $1.65-24.81$ \\
\hline \multirow[t]{3}{*}{ Index ranges } & $-22 \leq h \leq 22$ & $-17 \leq h \leq 17$ \\
\hline & $-10 \leq k \leq 10$ & $-23 \leq k \leq 23$ \\
\hline & $-21 \leq l \leq 23$ & $-19 \leq l \leq 19$ \\
\hline no. of reflns collected & 14555 & 49895 \\
\hline no. of indep reflns $\left(R_{\text {int }}\right)$ & $5145(0.0394)$ & $7919(0.0648)$ \\
\hline no. of data/restraints/params & 5145 / $141 / 476$ & $7919 / 0$ / 524 \\
\hline$G o F / F^{2}$ & 0.968 & 0.986 \\
\hline$R 1^{\mathrm{a}}, w R 2^{\mathrm{b}}(I>2 \sigma(I))$ & $0.0364,0.0820$ & $0.0430,0.1020$ \\
\hline$R 1^{\mathrm{a}}, w R 2^{\mathrm{b}}$ (all data) & $0.0582,0.0877$ & $0.0671,0.1100$ \\
\hline largest diff peak/hole $\left(\mathrm{e} \cdot \AA^{-3}\right)$ & $0.163 /-0.208$ & $0.170 /-0.204$ \\
\hline
\end{tabular}




\begin{tabular}{|c|c|c|}
\hline Compounds & 21 & 22 \\
\hline Formula & $\mathrm{C}_{58} \mathrm{H}_{75} \mathrm{AlN}_{5}$ & $\mathrm{C}_{44} \mathrm{H}_{51} \mathrm{AlN}_{2} \mathrm{O}_{2}$ \\
\hline Fw & 869.21 & 666.85 \\
\hline temp $(\mathrm{K})$ & $133(2)$ & $133(2)$ \\
\hline crystal syst & monoclinic & triclinic \\
\hline space group & $P 2(1) / c$ & $P-1$ \\
\hline$a(\AA)$ & $22.289(5)$ & $10.232(5)$ \\
\hline$b(\AA)$ & $13.057(3)$ & $11.111(4)$ \\
\hline$c(\AA)$ & $18.765(4)$ & $18.195(7)$ \\
\hline$\alpha(\mathrm{deg})$ & & $89.49(1)$ \\
\hline$\beta(\operatorname{deg})$ & 109.71(3) & $87.96(1)$ \\
\hline$\gamma(\operatorname{deg})$ & & $63.51(1)$ \\
\hline$V\left(\AA^{3}\right)$ & $5141(2)$ & $1850(1)$ \\
\hline $\mathrm{Z}$ & 4 & 2 \\
\hline$\rho_{c}\left(\mathrm{Mg} / \mathrm{m}^{3}\right)$ & 1.123 & 1.197 \\
\hline$\mu\left(\mathrm{mm}^{-1}\right)$ & 0.081 & 0.774 \\
\hline$F(000)$ & 1884 & 716 \\
\hline$\theta$ range (deg) & $1.84-24.87$ & $2.43-58.83$ \\
\hline \multirow[t]{3}{*}{ Index ranges } & $-26 \leq h \leq 26$ & $-11 \leq h \leq 11$ \\
\hline & $-15 \leq k \leq 15$ & $-11 \leq k \leq 12$ \\
\hline & $-22 \leq l \leq 19$ & $0 \leq l \leq 20$ \\
\hline no. of reflns collected & 53490 & 5023 \\
\hline no. of indep reflns $\left(R_{\text {int }}\right)$ & $8850(0.0825)$ & $5023(0.0000)$ \\
\hline no. of data/restraints/params & $8850 / 0$ / 602 & $5023 / 0 / 443$ \\
\hline$G o F / F^{2}$ & 0.958 & 1.053 \\
\hline$R 1^{\mathrm{a}}, w R 2^{\mathrm{b}}(I>2 \sigma(I))$ & $0.0560,0.1371$ & $0.0864,0.2678$ \\
\hline$R 1^{\mathrm{a}}, w R 2^{\mathrm{b}}$ (all data) & $0.0933,0.1508$ & $0.0888,0.2694$ \\
\hline largest diff peak/hole $\left(\mathrm{e} \cdot \AA^{-3}\right)$ & $0.589 /-0.437$ & $1.19 /-0.675$ \\
\hline
\end{tabular}




\begin{tabular}{|c|c|c|}
\hline Compounds & 23·0.89ether 0.11 toluene & 24.0.45ether $\cdot 0.55$ toluene \\
\hline Formula & $\mathrm{C}_{42} \mathrm{H}_{69} \mathrm{AlN}_{2} \mathrm{O}_{3} \mathrm{Si}_{2}$ & $\mathrm{C}_{72.73} \mathrm{H}_{108.85} \mathrm{Al}_{2} \mathrm{~N}_{4} \mathrm{O}_{0.43} \mathrm{~S}_{2} \mathrm{Si}_{2}$ \\
\hline $\mathrm{Fw}$ & 733.15 & 1220.28 \\
\hline temp $(\mathrm{K})$ & $100(2)$ & $100(2)$ \\
\hline crystal syst & triclinic & monoclinic \\
\hline space group & $P-1$ & $C c$ \\
\hline$a(\AA)$ & $10.166(2)$ & $18.903(1)$ \\
\hline$b(\AA)$ & $12.783(3)$ & $18.624(1)$ \\
\hline$c(\AA)$ & $17.392(4)$ & $20.125(1)$ \\
\hline$\alpha(\operatorname{deg})$ & $77.18(3)$ & \\
\hline$\beta(\mathrm{deg})$ & $87.82(3)$ & $94.36(1)$ \\
\hline$\gamma(\operatorname{deg})$ & $81.05(3)$ & \\
\hline$V\left(\AA^{3}\right)$ & $2177(1)$ & $7065(1)$ \\
\hline $\mathrm{Z}$ & 2 & 4 \\
\hline$\rho_{c}\left(\mathrm{Mg} / \mathrm{m}^{3}\right)$ & 1.118 & 1.147 \\
\hline$\mu\left(\mathrm{mm}^{-1}\right)$ & 0.139 & 1.571 \\
\hline$F(000)$ & 800 & 2650 \\
\hline$\theta$ range (deg) & $0.76-23.61$ & $3.34-60.32$ \\
\hline \multirow[t]{3}{*}{ Index ranges } & $-10 \leq h \leq 10$ & $-20 \leq h \leq 20$ \\
\hline & $-11 \leq k \leq 13$ & $-20 \leq k \leq 20$ \\
\hline & $-16 \leq l \leq 19$ & $-22 \leq l \leq 22$ \\
\hline no. of reflns collected & 8590 & 15565 \\
\hline no. of indep reflns $\left(R_{\text {int }}\right)$ & $4994(0.0192)$ & $9399(0.0347)$ \\
\hline no. of data/restraints/params & 4994 / 0 / 451 & 9399 / 2 / 772 \\
\hline$G o F / F^{2}$ & 1.025 & 1.022 \\
\hline$R 1^{\mathrm{a}}, w R 2^{\mathrm{b}}(I>2 \sigma(I))$ & $0.0488,0.1232$ & $0.0351,0.0779$ \\
\hline$R 1^{\mathrm{a}}, w R 2^{\mathrm{b}}$ (all data) & $0.0511,0.1253$ & $0.0433,0.0813$ \\
\hline largest diff peak/hole $\left(\mathrm{e} \cdot \AA^{-3}\right)$ & $0.478 /-0.470$ & $0.342 /-0.187$ \\
\hline
\end{tabular}




\begin{tabular}{|c|c|c|}
\hline Compounds & 25 & 26 \\
\hline Formula & $\mathrm{C}_{59} \mathrm{H}_{78} \mathrm{AlN}_{3}$ & $\mathrm{C}_{59} \mathrm{H}_{78} \mathrm{AlN}_{3}$ \\
\hline Fw & 856.22 & 856.22 \\
\hline temp $(\mathrm{K})$ & $133(2)$ & $133(2)$ \\
\hline crystal syst & monoclinic & triclinic \\
\hline space group & $P 2(1) / n$ & $P-1$ \\
\hline$a(\AA)$ & $12.350(1)$ & $11.806(8)$ \\
\hline$b(\AA)$ & $26.264(2)$ & $12.766(5)$ \\
\hline$c(\AA)$ & $16.011(1)$ & $19.718(8)$ \\
\hline$\alpha(\mathrm{deg})$ & & $76.04(3)$ \\
\hline$\beta(\operatorname{deg})$ & $104.05(1)$ & $74.54(4)$ \\
\hline$\gamma(\operatorname{deg})$ & & $64.63(4)$ \\
\hline$V\left(\AA^{3}\right)$ & $5038(1)$ & $2560(2)$ \\
\hline $\mathrm{Z}$ & 4 & 2 \\
\hline$\rho_{c}\left(\mathrm{Mg} / \mathrm{m}^{3}\right)$ & 1.129 & 1.111 \\
\hline$\mu\left(\mathrm{mm}^{-1}\right)$ & 0.081 & 0.079 \\
\hline$F(000)$ & 1864 & 932 \\
\hline$\theta$ range (deg) & $1.52-24.81$ & $1.08-24.81$ \\
\hline \multirow[t]{3}{*}{ Index ranges } & $-14 \leq h \leq 14$ & $-13 \leq h \leq 13$ \\
\hline & $-30 \leq k \leq 31$ & $-15 \leq k \leq 15$ \\
\hline & $-18 \leq l \leq 15$ & $-22 \leq l \leq 23$ \\
\hline no. of reflns collected & 24428 & 39096 \\
\hline no. of indep reflns $\left(R_{\text {int }}\right)$ & $8626(0.0929)$ & $8758(0.0409)$ \\
\hline no. of data/restraints/params & $8626 / 0 / 586$ & $8758 / 0$ / 270 \\
\hline$G o F / F^{2}$ & 1.011 & 1.039 \\
\hline$R 1^{\mathrm{a}}, w R 2^{\mathrm{b}}(I>2 \sigma(I))$ & $0.0633,0.1360$ & $0.0595,0.1415$ \\
\hline$R 1^{\mathrm{a}}, w R 2^{\mathrm{b}}$ (all data) & $0.1059,0.1551$ & $0.0751,0.1496$ \\
\hline largest diff peak/hole $\left(\mathrm{e} \cdot \AA^{-3}\right)$ & $0.433 /-0.251$ & $0.644 /-0.527$ \\
\hline
\end{tabular}




\section{References}

[1] H. W. Roesky, D. A. Atwood, Group 13 Chemistry II Biological Aspects of Aluminum, Springer-Verlag Berlin Heidelberg, 2002, Preface.

[2] W. Hallwachs, A. Schafarik, Liebigs Ann. Chem. 1959, 109, 207-210.

[3] G. B. Buckton, W. Odling, Liebigs Ann. Chem. (suppl.), 1865, 4, 109-111.

[4] J. J. Eisch, Comprehensive Organometallic Chemistry II, Eds: E. W. Abel, F. G. A. Stone, G. Wilkincon, Elsevier: Oxford, UK, 1995, Vol. II, 557-569.

[5] K. Ziegler, Angew. Chem. 1952, 64, 323-324, 330-335; 1956, 68, 721-729.

[6] K. Ziegler, in Organometallic Chemistry, Ed: H. H. Ziess, Reinhold: New York 1960, 194-269.

[7] H. Sinn, W. Kaminsky, Adv. Organomet. Chem. 1980, 18, 99-149.

[8] R. O. Colclough, J. Polym. Sci. 1959, 34, 171-178.

[9] R. O. Colclough, G. Gee, A. H. Jagger, J. Polym. Sci. 1960, 48, 270-275.

[10] E. J. Vandenberg, J. Polym. Sci. 1960, 47, 486-489.

[11] S. I. Ishida, J. Polym. Sci. 1962, 62, 1-14.

[12] C. Longiave, R. Castelli, J. Polym. Sci. 1963, 4C, 387-398

[13] T. Saegusa, Y. Fujii, H. Fujii, J. Furukawa, Makromol. Chem. 1962, 55, 232-236.

[14] G. B. Sakharovskaya, Zh. Obshch. Khim. 1969, 39, 788-795.

[15] H. Sinn, W. Kaminsky, H. J. Vollmer, R. Woldt, Angew. Chem. 1980, 92, 396-402; Angew. Chem. Int. Ed. Engl. 1980, 19, 390-392.

[16] H. Sinn, W. Kaminsky, Adv. Organomet. Chem. 1980, 18, 99-149.

[17] M. N. S. Rao, H. W. Roesky, G. Anantharaman, J. Organomet. Chem. 2002, 646, 4-14

[18] (a) H. W. Roesky, Inorg. Chem. 2004, 43, 7284-7293. (b) M. Witt, H. W. Roesky, Curr. Science 2000, 78, 410-424.

[19] B. E. Bent, R. G. Nuzzo, L. H. Dubois, J. Am. Chem. Soc. 1989, 111, 1634-1644.

[20] L. Contreras, A. H. Cowley, F. P. Gabbai, R. A. Jones, C. J. Carrano, M. R. Bond, J. Organomet. Chem. 1995, 489, C1-C3.

[21] C. Cui, H. W. Roesky, H. Hao, H.-G. Schmidt, M. Noltemeyer, Angew. Chem. 2000, 112, 18851887; Angew. Chem. Int. Ed. 2000, 39, 1815-1817.

[22] M. G. Gardiner, C. L. Raston, V.-A. Tolhurst, J. Chem. Soc., Chem. Commun. 1995, 1457-1458.

[23] M. G. Gardiner, C. L. Raston, V.-A. Tolhurst, J. Chem. Soc., Chem. Commun. 1995, 2501-2502.

[24] P. D. Godfrey, C. L. Raston, B. W. Skelton, V.-A. Tolhurst, A. H. White, Chem. Commun. 1997, 2235-2236.

[25] W. J. Grigsby, C. L. Raston, V.-A. Tolhurst, B. W. Skelton, A. H. White, J. Chem. Soc. Dalton Trans. 1998, 2547-2556.

[26] R. J. Wehmschulte, P. P. Power, Chem. Commun. 1998, 335-336.

[27] V. Jancik, Y. Peng, H. W. Roesky, J. Li, D. Neculai, A. M. Neculai, R. Herbst-Irmer, J. Am. Chem. Soc. 2003, 125, 1452-1453. 
[28] C. Cui, H. W. Roesky, M. Noltemeyer, H.-G. Schmidt, Organometallics 1999, 18, 5120-5123.

[29] C. Cui, H. W. Roesky, M. Noltemeyer, H.-G. Schmidt, Inorg. Chem. 2000, 39, 3678-3681.

[30] W. Zheng, N. C. Mösch-Zanetti, H. W. Roesky, M. Noltemeyer, M. Hewitt, H.-G. Schmidt, T. R. Schneider, Angew. Chem. 2000, 112, 4446-4449; Angew. Chem. Int. Ed. 2000, 39, 42764279 .

[31] J. D. Scollard, D. H. McConville, J. J. Vittal, Organometallics 1997, 16, 4415-4420.

[32] J. D. Scollard, D. H. McConville, J. Am. Chem. Soc. 1996, 118, 10008-10009.

[33] P. W. Roesky, Organometallics 2002, 21, 4756-4761.

[34] F. G. N. Cloke, B. R. Elvidge, P. B. Hitchcock, V. M. E. Lamarche, J. Chem. Soc., Dalton Trans. 2002, 2413-2414.

[35] D. Chakraborty, E. Y.-X. Chen, Organometallics 2002, 21, 1438-1442.

[36] R. J. Wehmschulte, P. P. Power, Polyhedron 2000, 19, 1649-1661, and references therein.

[37] J. L. Atwood, S. M. Lawrence, C. L. Raston, J. Chem. Soc., Chem. Commun. 1994, 73-74.

[38] M. G. Gardiner, S. M. Lawrence, C. L. Raston, J. Chem. Soc., Dalton Trans. 1996, 4163-4169.

[39] M. G. Gardiner, C. L. Raston, Coord. Chem. Rev. 1997, 166, 1-34.

[40] H. V. Dias, W. Jin, R. E. Ratcliff, Inorg. Chem. 1995, 34, 6100-6105.

[41] J. F. Janik, R. L. Wells, P. S. White, Inorg. Chem. 1998, 37, 3561-3566.

[42] W. Zheng, H. W. Roesky, M. Noltemeyer, Organometllics 2001, 20, 1033-1035.

[43] N. Kuhn, S. Fuchs, M. Steimann, Z. Anorg. Allg. Chem. 2000, 626, 1387-1392.

[44] J. L. Atwood, G. A. Koutsantonis, F.-C. Lee, C. L. Raston, J. Chem. Soc., Chem. Commun. 1994, 91-92.

[45] S. Cucinella, A. Mazzei, W. Marconi, Inorg. Chim. Acta Rev. 1970, 4, 51-71.

[46] S. D. Waezsada, F.-Q. Liu, E. F. Murphy, H. W. Roesky, M. Teichert, I. Usón, H. -G. Schmidt, T. Albers, E. Parisini, M. Noltemeyer, Organometallics 1997, 16, 1260-1264.

[47] A. H. Cowley, H. S. Isom, A. Decke, Organometallics 1995, 14, 2589-2592.

[48] G. Linti, H. Nöth, P. Rahm, Z. Naturforsch, 1988, B43, 1101-1112.

[49] C.-C. Chang, M.-D. Li, M. Y. Chiang, S.-M. Peng, Y. Wang, G.-H. Lee, Inorg. Chem. 1997, 36, 1955-1960.

[50] R. J. Wehmschulte, P. P. Power, Inorg. Chem. 1996, 35, 3262-3267.

[51] C. Schnitter, K. Klimek, H. W. Roesky, T. Albers, H.-G. Schmidt, C. Röpken, E. Parisini, Organometallics 1998, 17, 2249-2257.

[52] G. Shanmugasunderan, G. Z. Nagarajan, Phys. Chem. 1969, 240, 363-370.

[53] C. Klein, H. Nöth, M. Tacke, M. Thomann, Angew. Chem. 1993, 105, 923-926; Angew. Chem. Int. Ed. 1993, 32, 886-889.

[54] G. Almenningen, G. Gundersen, T. Haugen, A. Haaland, Acta Chem. Scand. 1972, 26, 39283934.

[55] G. A. Anderson, F. R. Forgaard, A. Haaland, Acta Chem. Scand. 1972, 26, 1947-1954. 
[56] Some spectroscopic data are listed for $\left[\mathrm{LAl}(\mathrm{SeH})_{2}\right]$ (reference 21): ${ }^{1} \mathrm{H} \mathrm{NMR}\left(500 \mathrm{MHz}, \mathrm{C}_{6} \mathrm{D}_{6}\right)$, $\delta_{\mathrm{SeH}}=-2.82 ; \mathrm{IR}(\mathrm{KBr}, \mathrm{Nujol}), \tilde{v}_{\mathrm{SeH}}=2318 \mathrm{~cm}^{-1}$ and $[\mathrm{L}(\mathrm{HSe}) \operatorname{AlSeAl}(\mathrm{SeH}) \mathrm{L}]:{ }^{1} \mathrm{H}$ NMR $(500$ $\left.\mathrm{MHz}, \mathrm{C}_{6} \mathrm{D}_{6}\right), \delta_{\mathrm{SeH}}=-2.83,{ }^{77} \mathrm{Se} \mathrm{NMR}\left(500 \mathrm{MHz}, \mathrm{C}_{6} \mathrm{D}_{6}\right), \delta_{\mathrm{Al}-\mathrm{SeH}}=-341$ and $\delta_{\mathrm{Al}-\mathrm{Se}-\mathrm{Al}}=-535 ; \mathrm{IR}$ $(\mathrm{KBr}, \mathrm{Nujol}), \widetilde{v}_{\mathrm{SeH}}=2276,2292 \mathrm{~cm}^{-1}$.

[57] C. Sishta, R. M. Hathorn, T. J. Marks, J. Am. Chem. Soc. 1992, 114, 1112-1114.

[58] H. H. Brintzinger, D. Fischer, R. Mülhaupt, B. Rieger, R. Waymouth, Angew. Chem. 1995, 107, 1255-1283; Angew. Chem., Int. Ed. Engl. 1995, 34, 1143-1170.

[59] Y. Koide, S. G. Bott, A. R. Barron, Organometallics 1996, 15, 2213-2226.

[60] A. Storr, K. Jones, A. W. Laubengayer, J. Am. Chem. Soc. 1968, 90, 3173-3177.

[61] M. Bolesławski, S. Pasynkiewicz, A. Minorska, W. Hryniów, J. Organomet. Chem. 1974, 65, 165-167.

[62] K. Ziegler, F. Krupp, K. Weyer, W. Larbig, Liebigs Ann. Chem. 1960, 629, 251-256.

[63] R. J. Wehmschulte, P. P. Power, J. Am. Chem. Soc. 1997, 119, 8387-8388.

[64] M. Boleslawski, J. Serwatowski, J. Organomet. Chem. 1983, 255, 269-274.

[65] N. Kuhn, S. Fuchs, E. Niquet, M. Richter, M. Steimann, Z. Anorg. Allg. Chem. 2002, 628, $717-$ 718.

[66] M. R. Mason, J. M. Smith, S. G. Bott, A. R. Barron, J. Am. Chem. Soc. 1993, 115, 4971-4984.

[67] C. J. Harlan, M. R. Mason, A. R. Barron, Organometallics 1994, 13, 2957-2969.

[68] C. C. Landry, C. J. Harlan, S. G. Bott, A. R. Barron, Angew. Chem. 1995, 107, 1315-1317; Angew. Chem., Int. Ed. Engl. 1995, 107, 1201-1203.

[69] J. Storre, C. Schnitter, H. W. Roesky, H.-G. Schmidt, M. Noltemeyer, R. Fleischer, D. Stalke, J. Am. Chem. Soc. 1996, 118, 1380-1386.

[70] J. Storre, C. Schnitter, H. W. Roesky, H.-G. Schmidt, M. Noltemeyer, R. Fleischer, D. Stalke, J. Am. Chem. Soc. 1997, 119, 7505-7513.

[71] S. S. Kumar, S. Singh, H. W. Roesky, J. Magull, Inorg. Chem. 2005, 44, in press.

[72] Y. Peng, G. Bai, H. Fan, D. Vidovic, H. W. Roesky, J. Magull, Inorg. Chem. 2004, 43, 1217 1219.

[73] D. Neculai, H. W. Roesky, A. M. Neculai, J. Magull, B. Walfort, D. Stalke, Angew. Chem. 2002, 114, 4470-4472; Angew. Chem., Int. Ed. 2002, 41, 4294-4296.

[74] C. N. McMahon, A. R. Barron, J. Chem. Soc., Dalton Trans. 1998, 3703-3704.

[75] G. Bai, Y. Peng, H. W. Roesky, J. Li, H.-G. Schmidt, M. Noltemeyer, Angew. Chem. 2003, 115, 1164-1167; Angew. Chem., Int. Ed. 2003, 42, 1132-1135.

[76] V. Jancik, L. W. Pineda, J. Pinkas, H. W. Roesky, D. Neculai, A. M. Neculai, R. Herbst-Irmer, Angew. Chem. 2004, 116, 2194-2197; Angew. Chem., Int. Ed. 2004, 43, 2142-2145.

[77] The structural data for $\mathrm{LAlI}_{2}$ are resulted in the PhD Thesis of C. Cui, Göttingen, 2001, 41.

[78] M. Schiefer, N. D. Reddy, H. W. Roesky, D. Vidovic, Organometallics 2003, 22, 3637-3638. 
[79] W. Zheng, N. C. Mösch-Zanetti, T. Blunck, H. W. Roesky, M. Noltemeyer, H.-G. Schmidt, Organometallics 2001, 20, 3299-3303.

[80] G. Bai, H. W. Roesky, J. Li, M. Noltemeyer, H.-G. Schmidt, Angew. Chem. 2003, 115, 56605664; Angew. Chem., Int. Ed. 2003, 42, 5502-5506.

[81] (a) B. Qian, D. L. Ward, M. R. Smith, III, Organometallics 1998, 17, 3070-3076. (b) D. H. M. Budzelaar, A. B. van Oort, A. G. Orpen, Eur. J. Inorg. Chem. 1998, 1485-1494.

[82] Y. Ding, H. Hao, H. W. Roesky, M. Noltemeyer, H.-G. Schmidt, Organometallics 2001, 20, 4806-4811.

[83] Y. Ding, Q. Ma, H. W. Roesky, R. Herbst-Irmer, I. Usón, M. Noltemeyer, H.-G. Schmidt, Organometallics 2002, 21, 5216-5220.

[84] S. Harder, Angew. Chem. 2003, 115, 3553-3556; Angew. Chem., Int. Ed. 2003, 42, 3430-3434.

[85] A. F. Holleman, E. Wiberg, N. Wiberg, Lehrbuch der Anorganischen Chemie Walter de Gruyter, Berlin, 1995, p1075.

[86] D. Chakraborty, E. Y.-X. Chen, Organometallics 2003, 22, 207-210.

[87] $\mathrm{D}_{298}^{\circ}(\mathrm{Al}-\mathrm{I})=369.9 \pm 2.1 \mathrm{KJ} / \mathrm{mol} ; \mathrm{D}_{298}^{\circ}(\mathrm{Al}-\mathrm{Cl})=511.3 \pm 0.9 \mathrm{KJ} / \mathrm{mol}$. Handbook of Chemistry and Physics (Ed.: D. R. Lide,) 2003-2004, 84, 9-19.

[88] L. J. Zakharkin, I. M. Khorlina, Izv. Akad, Nauk SSSR, Ser. Khim. 1959, 2146-2149.

[89] D. W. Harney, A. Meisters, T. Mole, Aust. J. Chem. 1974, 27, 1639-1653.

[90] W. Uhl, M. Koch, W. Hiller, M. Heckel, Angew. Chem. 1995, 107, 1122-1124; Angew. Chem. Int. Ed. 1995, 34, 989-991.

[91] M. Boleslawski, S. Pasynkiewicz, J. Organomet. Chem. 1972, 43, 81-93.

[92] A. G. Davies, B. P. Roberts, J. Chem. Soc. (B), 1968, 1074-1076.

[93] J. Lewiński, J. Zachara, P. Goś, E. Grabska, T. Kopeć, I. Madura, W. Marciniak, I. Prowotorow, Chem. Eur. J. 2000, 6, 3215-3222.

[94] J. Lewiński, J. Zachara, E. Grabska, J. Am. Chem. Soc. 1996, 118, 6794-6795.

[95] C. Cui, H. W. Roesky, H.-G. Schmidt, M. Noltemeyer, H. Hao, F. Cimpoesu, Angew. Chem. 2000, 112, 4444-4446; Angew. Chem. Int. Ed. 2000, 39, 4274-4276.

[96] J. Bahlo, H.-J. Himmel, H. Schnöckel, Angew. Chem. 2001, 113, 4820-4824; Angew. Chem. Int. Ed. 2001, 40, 4696-4500.

[97] J. Bahlo, H.-J. Himmel, H. Schnöckel, Inorg. Chem. 2002, 41, 2678-2689.

[98] A. N. Sanalov, V. N. Bibin, Surf. Sci. 1999, 441, 399-409.

[99] (a) D. J. E. Spencer, N. W. Aboelella, A. M. Reynolds, P. L. Holland, W. B. Tolman, J. Am. Chem. Soc. 2002, 124, 2108-2109. (b) N. W. Aboelella, E. A. Lewis, A. M. Reynolds, W. W. Brennessel, C. J. Cramer, W. B. Tolman, J. Am. Chem. Soc. 2002, 124, 10660-10661.

[100] Based on a radius of $1.3 \AA$ for $\mathrm{Al}$ and $0.66 \AA$ for O: L. Pauling, The Nature of the Chemical Bond, $3^{\text {rd }}$ ed., Cornell University Press: Ithaca, NY, 1960, p 221.

[101] M. D. Healy, J. W. Ziller, A. R. Barron, J. Am. Chem. Soc. 1990, 112, 2949-2974. 
[102] D. L. Lichtenberger, R. H. Hogan, M. D. Healy, A. R. Barron, J. Am. Chem. Soc. 1990, 112, 3369-3374.

[103] M. D. Healy, J. W. Ziller, A. R. Barron, Organometallics 1991, 10, 597-604.

[104] M. A. Petrie, M. M. Olmstead, P. P. Power, J. Am. Chem. Soc, 1991, 113, 8704-8708.

[105] W. Uhl, M. Koch, S. Pohl, W. Saak, W. Hiller, M. Heckel, Z. Naturforsch. 1995, 50b, 635-641.

[106] D. Neculai, H. W. Roesky, A. M. Neculai, J. Magull, B. Walfort, D. Stalke, Angew. Chem. 2002, 114, 4470-4472; Angew. Chem. Int. Ed. 2002, 41, 4294-4296.

[107] N. Kuhn, S. Fuchs, E. Niquet, M. Richter, M. Steimann, Z. Anorg. Allg. Chem. 2002, 628, 717718.

[108] H. Zhu, J. Chai, C. He, G. Bai, H. W. Roesky, V. Jancik, H.-G. Schmidt, M. Noltemeyer, Organometallics 2005, 24, 380-384.

[109] V. Jancik, M. M. Moya Cabrera, H. W. Roesky, R. Herbst-Irmer, D. Neculai, A. M. Neculai, M. Noltemeyer, H.-G. Schmidt, Eur. J. Inorg. Chem. 2004, 3508-3512.

[110] S. Harder, Organometallics 2002, 21, 3782-3787.

[111] C. W. Haigh, R. B. Mallion, Prog. Nucl. Magn. Reson. Spectrosc. 1980, 13, 303-323.

[112] P. P. Power, J. Chem. Soc. Dalton Trans. 1998, 2939-2951.

[113] P. P. Power, Chem. Rev. 1999, 99, 3463-3503.

[114] W. Uhl, Rev. Inorg. Chem. 1998, 18, 239-282, and references therein.

[115] C. Dohmeier, C. Robl, M. Tacke, H. Schnöckel, Angew. Chem. 1991, 103, 594-595; Angew. Chem. Int. Ed. Engl. 1991, 30, 564-565.

[116] E. P. Schram, N. Sudha, Inorg. Chim. Acta 1991, 183, 213-216.

[117] S. Schulz, H. W. Roesky, H. J. Koch, G. M. Sheldrick, D. Stalke, A. Kuhn, Angew. Chem. 1993, 105, 1828-1830; Angew. Chem. Int. Ed. Engl. 1993, 32, 1729-1731.

[118] C. Schnitter, H. W. Roesky, C. Röpken, R. Herbst-Irmer, H.-G. Schmidt, M. Noltemeyer, Angew. Chem. 1998, 110, 2059-2062; Angew. Chem. Int. Ed. Engl. 1998, 37, 1952-1955.

[119] M. Schormann, K. S. Klimek, H. Hatop, S. P. Varkey, H. W. Roesky, C. Lehmann, C. Röpken, R. Herbst-Irmer, M. Noltemeyer, J. Solid State Chem. 2001, 162, 225-236.

[120] A. Purath, H. Schnöckel, J. Organomet. Chem. 1999, 579, 373-376.

[121] J. Gauss, U. Schneider, R. Ahlrichs, C. Dohmeier, H. Schnöckel, J. Am. Chem. Soc. 1993, 115, $2402-2408$.

[122] A. Haaland, K.-G. Martinsen, S. A. Shlykov, H. V. Volden, C. Dohmeier, H. Schnöckel, Organometallics 1995, 14, 3116-3119.

[123] C. Dohmeier, H. Schnöckel, C. Robl, U. Schneider, R. Ahlrichs, Angew. Chem. 1994, 106, $225-$ 227; Angew. Chem. Int. Ed. Engl. 1994, 33, 199-201.

[124] S. Schulz, L. Häming, R. Herbst-Irmer, H. W. Roesky, G. M. Sheldrick, Angew. Chem. 1994, 106, 1052-1054; Angew. Chem. Int. Ed. Engl. 1994, 33, 969-971. 
[125] C. Dohmeier, H. Krautscheid, H. Schnöckel, Angew. Chem. 1994, 106, 2570-2571; Angew. Chem. Int. Ed. Engl. 1994, 33, 2482-2483.

[126] S. Schulz, T. Schoop, H. W. Roesky, L. Häming, A. Steiner, R. Herbst-Irmer, Angew. Chem. 1995, 107, 1015-1016; Angew. Chem. Int. Ed. Engl. 1995, 34, 919-920.

[127] S. Schulz, A. Voigt, H. W. Roesky, L. Häming, R. Herbst-Irmer, Organometallics 1996, 15, $5252-5263$.

[128] A. G. Davies, B. P. Roberts, J. Chem. Soc. (B), 1968, 1074-1078.

[129] C. Cui, H. W. Roesky, H. Hao, H.-G. Schmidt, M. Noltemeyer, Angew. Chem. 2000, 112, 47054707; Angew. Chem. Int. Ed. 2000, 39, 4531-4533.

[130] N. J. Hardman, C. Cui, H. W. Roesky, W. H. Fink, P. P. Power, Angew. Chem. 2001, 113, 2230-2232; Angew. Chem. Int. Ed. 2001, 40, 2172-2174.

[131] Y. Peng, H. Fan, H. Zhu, H. W. Roesky, J. Magull, O. E. Hughes, Angew. Chem. 2004, 116, 3525-3527; Angew. Chem. Int. Ed. 2004, 43, 3443-3445.

[132] N. Kuhn, T. Kratz, Synthesis 1993, 561-562.

[133] H. Staudinger, E. Anthes, F. Pfenninger, Ber. Dtsch. Chem. Ges. 1916, 49, 1928-1941.

[134] K. Ziegler, H.-G. Gellert, H. Lehmkuhl, W. Pfohl, K. Zosel, Liebigs Ann. Chem. 1960, 629, 113.

[135] W. A. Herrmann, J. L.Hubbard, I. Bernal, J. D. Korp, B. L. Haymore, G. L. Hillhouse, Inorg. Chem. 1984, 23, 2978-2983.

[136] R. J. Baker, R. D. Farley, C. Jones, M. Kloth, D. M. Murphy, Chem. Commun. 2002, 11961197.

[137] A. J. Arduengo, III, H. V. R. Dias, J. C. Calabrese, F. Davidson, J. Am. Chem. Soc. 1992, 114, 9724-9725.

[138] X.-X. Li, J. Su, G. H. Robinson, Chem. Commun. 1996, 2683-2684.

[139] C. J. Carmalt, A. H. Cowley, Adv. Inorg. Chem. 2000, 50, 1-61, and references therein.

[140] R. J. Baker, A. J. Davies, C. Jones, M. Kloth, J. Organomet. Chem. 2002, 656, 203-210.

[141] J. D. Gorden, C. L. B. Macdonald, A. H. Cowley, J. Organomet. Chem. 2002, 643-644, 487489.

[142] H. Zhu, J. Chai, H. W. Roesky, M. Noltemeyer, H.-G. Schmidt, D. Vidovic, J. Magull, Eur. J. Inorg. Chem. 2003, 17, 3113-3119.

[143] W. Kirmse, Carbene Chemistry 2nd edition, Academic Press, New York, 1971, 85-128, and references therein.

[144] D. Bethell, K. L. Handoo, S. A. Fairhurst, L. H. Sutcliffe, J. Chem. Soc. Chem. Commun. 1977, 326-328.

[145] P. J. Brothers, P. P. Power, Adv. Organomet. Chem. 1996, 39, 1-69.

[146] K. M. Waggoner, H. Hope, P. P. Power, Angew. Chem. 1988, 100, 1765-1766; Angew, Chem. Int. Ed. Engl. 1988, 27, 1699-1700. 
[147] K. M. Waggoner, P. P. Power, J. Am. Chem. Soc. 1991, 113, 3385-3393.

[148] G. M. Sheldrick, W. S. Sheldrick, J. Chem. Soc. A. 1969, 2279-2293.

[149] For the structural model $\mathrm{X}_{1,2}-\mathrm{C}=\mathrm{N}-\mathrm{Y}$, the range of $\mathrm{C}=\mathrm{N}$ double bond length is 1.279-1.302 $\AA$. F. H. Allen, P. Kennard, D. G. Waston, L. Brammer, A. G. Orpen, R. Taylor, J. Chem. Soc. Perkin Trans. 2, 1987, S1-S19.

[150] C. Dohmeier, D. Loos, H. Schnöckel, Angew. Chem. 1996, 108, 141-161; Angew. Chem., Int. Ed. 1996, 35, 129-149.

[151] W. Uhl, S. U. Keimling, S. Pohl, W. Saak, R. Wartchow, Chem. Ber. 1997, 130, 1269-1272.

[152] A. H. Cowley, J. D. Gorden, C. D. Abernethy, J. A. C. Clyburne, B. G. Burnett, J. Chem. Soc., Dalton Trans. 1998, 1937-1938.

[153] W. Uhl, M. Pohlmann, Chem. Commun. 1998, 451-452.

[154] E. C. Taylor, The Chemistry of Heterocyclic Compounds, Wiley, New York, 1993.

[155] C. Cui, S. Köpke, R. Herbst-Irmer, H. W. Roesky, M. Noltemeyer, H.-G. Schmidt, B. Wrackmeyer, J. Am. Chem. Soc. 2001, 123, 9091-9098.

[156] H. Zhu, J. Chai, Q. Ma, V. Jancik, H. W. Roesky, H. Fan, R. Herbst-Irmer, J. Am. Chem. Soc. 2004, 126, 10194-10195.

[157] R. S. Dickson, J. A. Ibers, S. Otsuka, Y. Tatsuno, J. Am. Chem. Soc. 1971, 93, 4636-4637.

[158] W. J. Evans, D. K. Drummond, L. R. Chamberlain, R. J. Doedens, S. G. Bott, H. C. Zhang, J. L. Atwood, J. Am. Chem. Soc. 1988, 110, 4983-4994.

[159] J. Takats, X. W. Zhang, V. W. Day, T. A. Eberspacher, Organometallics 1993, 12, 4286-4288.

[160] W. Uhl, F. Hannemann, Eur. J. Inorg. Chem. 1999, 201-207.

[161] G. Gullemot, E. Solari, R. Scopelliti, C. Floriani, Organometallics 2001, 20, 2446-2448.

[162] J. M. Smith, R. J. Lachicotte, P. L. Holland, J. Am. Chem. Soc. 2003, 125, 15752-15753.

[163] A. J. Craty, Organometal. Chem. Rev. A 1972, 191-243, and reference therein.

[164] A. Omenat, M. Ghedini, J. Chem. Soc., Chem. Commun. 1994, 1309-1310.

[165] S. A. Hudson, P. M. Maitlis, Chem. Rev. 1993, 93, 861-885.

[166] M. Ghedini, D.Pucci, A. Crispini, G. Barberio, Organometallics 1999, 18, 2116-2124.

[167] A. Risaliti, S. Bozzini, A. Stener, Tetrahedron 1969, 25, 143-148.

[168] R. Ahlrichs, M. Bär, H.-P. Baron, R. Bauernschmitt, S. Böcker, P. Deglmann, M. Ehrig, K. Eichkorn, S. Elliott, F. Furche, F. Haase, M. Häser, H. Horn, C. Hättig, C. Huber, U. Huniar, M. Katannek, A. Köhn, C. Kölmel, M. Kollwitz, K. May, C. Ochsenfeld, H. Öhm, A. Schäfer, U. Schneider, M. Sie, O. Treutler, B. Unterreiner, M. V. Arnim, F. Weigand, P. Weis, H. Weiss, TURBOMOLE 5.5, University of Karlsruhe, Germany, 2002.

[169] C. M. B. Marsh, T. P. Hamilton, Y. Xie, H. F. Schaefer, III, J. Chem. Phys. 1992, 96, 53105317.

[170] The $\mathrm{N}-\mathrm{N}$ bond strength for $\mathrm{H}_{2} \mathrm{~N}-\mathrm{NHPh}, \mathrm{D}_{298}{ }^{\circ}=57 \pm 2 \mathrm{kcal} / \mathrm{mol}$ is reported: D. F. McMillen, D. M. Golden, Ann. Rev. Phys. Chem. 1982, 33, 493-496. 
[171] E. Roskamp, C. Roskamp in Comprehensive Heterocyclic Chemistry II Vol. 2 (Ed: A. R. Katritzky, C. W. Rees, E. F. V. Scriven), Pergamon, Oxford, 1996, 305-332.

[172] A. Krebs, J. Berndt, Tetrahedron Lett. 1983, 4083-4086.

[173] M. P. Egorov, S. P. Kolesnikov, Yu. T. Struchkov, Yu. M. Antipin, S. V. Sereda, O. M. Nefedov, J. Organomet. Chem. 1985, 290, C27-C30.

[174] L. R. Sita, R. D. Bicherstaff, J. Am. Chem. Soc. 1988, 110, 5208-5209.

[175] W. Ando, H. Ohgaki, Y. Kabe, Angew. Chem. 1994, 96, 723-725; Angew. Chem. Int. Ed. Engl. 1994, 33, 659-661.

[176] M. H. Lien, A. C. Hopkinson, Chem. Phys. Lett. 1981, 80, 114-118.

[177] M. S. Gordan, R. D. Koob, J. Am. Chem. Soc. 1981, 103, 2939-2944.

[178] J. A. Boatz, M. S. Gordan, L. D. Sita, J. Phys. Chem. 1990, 94, 5488-5493.

[179] Y. Xie, H. F. Schaefer III, J. Am. Chem. Soc. 1990, 112, 5393-5400.

[180] H.-G. Himmel, Organometallics 2003, 22, 2679-2687.

[181] T. R. Burkholder, L. Andrews, Inorg. Chem. 1993, 32, 2491-2496.

[182] H. Hoberg, V. Gotor, A. Milchereit, C. Krüger, J. C. Sekutowski, Angew. Chem. 1977, 89, $563-$ 564; Angew. Chem. Int. Ed. Engl. 1977, 16, 539-540.

[183] H. Hoberg, F. Aznar, J. Organomet. Chem. 1979, 164, C13-C15.

[184] H. Schnöckel, M. Leimkühler, R. Lotz, R. Mattes, Angew. Chem. 1986, 98, 929-930; Angew. Chem. Int. Ed. Engl. 1986, 25, 921-922.

[185] C. Üffing, A. Ecker, R. Köppe, K. Merzweiler, H. Schnöckel, Chem. Eur. J. 1998, 4, $2142-$ 2147.

[186] G. D. Stucky, A. M. McPherson, W. E. Rhine, J. J. Eisch, J. L. Considine, J. Am. Chem. Soc. 1974, 96, 1941-1951.

[187] T. W. Dolzine, J. P. Oliver, J. Am. Chem. Soc. 1974, 96, 1737-1740.

[188] H.-D. Hausen, J. Tödtmann, J. Weidlein, Z. Naturforsch. 1994, 49B, 430-433.

[189] Structural parameters for $\mathrm{C}_{2} \mathrm{H}_{4}$ in the gas phase: $\mathrm{C}-\mathrm{C} 1.330 \AA, \mathrm{C}-\mathrm{H}, 1.076 \AA$, C-C-H $121.7^{\circ}$, H-C-H $116.6^{\circ}$; for $\mathrm{C}_{2} \mathrm{H}_{2}: \mathrm{C}-\mathrm{C} 1.203 \AA$, C-H $1.061 \AA$, C-C-H $180^{\circ}$. K. P. C. Vollhardt, N. E. Schore in Organic Chemistry (3 rd ed.), W. H. Freeman and Company (New York), 1998, p438 and $\mathrm{p} 543$.

[190] P. Jutzi, B. Neumann, G. Reumann, H.-G. Stammler, Organometallics 1999, 18, 2037-2040.

[191] R. J. Wright, A. D. Phillips, T. L. Allen, W. H. Fink, P. P. Power, J. Am. Chem. Soc. 2003, 125, 1694-1695.

[192] H. Zhu, J. Chai, V. Chandrasekhar, H. W. Roesky, J. Magull, D. Vidovic, H.-G. Schmidt, M. Noltemeyer, P. P. Power, W. A. Merrill, J. Am. Chem. Soc. 2004, 126, 9472-9473.

[193] F. Geoffrey, N. Cloke, G. R. Hanson, M. J. Henderson, P. B. Hitchcock, C. L. Raston, J. Chem. Soc., Commun. 1989, 1002-1003. 
[194] F. Geoffrey, N. Cloke, C. L. Dalby, M. J. Henderson, P. B. Hitchcock, C. H. L. Kennard, R. N. Lamb, C. L. Raston, J. Chem. Soc., Commun. 1990, 1394-1395.

[195] W. W. Schoeller, S. Grigoleit, J. Chem. Soc., Dalton Trans. 2002, 405-410.

[196] R. J. Baker, R. D. Farley, C. Jones, M. Kloth, D. M. Murphy, J. Chem. Soc., Commun. 2002, 97-98.

[197] D. S. Brown, A. Decken, A. H. Cowley, J. Am. Chem. Soc. 1995, 117, 5421-5422.

[198] E. S. Schmidt, A. Jockisch, H. Schmidbaur, J. Am. Chem. Soc. 1999, 121, 9758-9759.

[199] N. J. Hardman, B. E. Eichler, P. P. Power, Chem. Commun. 2000, 1991-1992.

[200] Selected examples: (a) G. Bai, H. W. Roesky, H. Hao, Inorg. Chem. 2001, 40, 2424-2426. (b) D. Huang, K. Folting, K. G. Caulton, J. Am. Chem. Soc. 1999, 121, 10318-10319. (c) K. Onitsuka, H. Katayama, K. Sonogashira, F. Ozawa, J. Chem. Soc., Chem. Commun. 1995, $2267-$ 2268 .

[201] See some examples: (a) W. Uhl, A. Vester, W. Hiller, J. Organomet. Chem. 1993, 443, 9-14. (b) A. Ecker, R. Köppe, C. Üffing, H. Schnöckel, Z. Anorg. Allg. Chem. 1998, 624, 817-820. (c) C. Schnitter, A. Klemp, H. W. Roesky, H.-G. Schmidt, C. Röpken, R. Herbst-Irmer, M. Noltemeyer, Eur. J. Inorg. Chem. 1998, 2033-2038.

[202] M. Taghiof, M. J. Heeg, M. Bailey, D. G. Dick, R. Kumar, D. G. Hendershot, H. Rahbarnoohi, J. P. Oliver, Organometallics 1995, 14, 2903-2910.

[203] M. Ishikawa, T. Fuchikami, M. Kumada, J. Am. Chem. Soc. 1979, 101, 1348-1353.

[204] The bond lengths of gas phase $\mathrm{CO}_{2}$ and $\mathrm{CS}_{2}$ are 1.1600 and $1.5526 \AA$, respectively. See Handbook of Chemistry and Physics (Ed.: D. R. Lide,) 2003-2004, 84, 9-19.

[205] $\mathrm{D}_{\mathrm{o}}\left(\mathrm{CO}_{2}\right.$, gas, $\left.273 \mathrm{~K}\right)=526.1 \pm 0.2 \mathrm{~kJ} / \mathrm{mol}, \mathrm{D}_{\mathrm{o}}\left(\mathrm{CS}_{2}\right.$, gas, $\left.273 \mathrm{~K}\right)=432.1 \pm 2 \mathrm{~kJ} / \mathrm{mol}$ : (a) $\mathrm{K}$. E. Mcculloh, J. Chem. Phys. 1973, 59, 4250-4255. (b) P. Coppens, J. C. Reynaert, J. Drowart, J. Chem. Soc. Faraday Trans. 1979, 75, 292-293.

[206] I. R. Grant, In Chemistry of Aluminum, Gallium, Indium and Thallium; A. J. Downs, Ed.; Blackie-Chapman \& Hall: London, 1993, Chapter 5.

[207] M. B. Smith, J. March, March's Advanced Organic Chemistry, 5th ed.; Wiley: New York, 2001, p 20.

[208] (a) M. Karplus, J. Am. Chem. Soc. 1963, 85, 2870-2881. (b) Lute Fitjer, NMR-Spektroskopie

[209] R. A. Kovar, J. O. Callaway, Inorg. Synth. 1975, 17, 63-67.

[210] E. Krause, Ber. Dtsch. Chem. Ges. 1918, 51, 1447-1456.

[211] P. P. Power, M. M. Olmstead, J. Organomet. Chem. 1991, 408, 1-8.

[212] G. M. Sheldrick, SHELXS-90, Program for Structure Solution, Acta Crystallogr., Sect. A 1990, 46, 467-473.

[213] G. M. Sheldrick, SHELXL-97, Program for Crystal Structure Refinement; University of Göttingen: Göttingen, Germany, 1997. 


\section{Abbreviations}

Ar

av

B.p.

$t \mathrm{Bu}$

Calcd

d

$d$

dec

$\operatorname{deg}$

$\eta$

EI

Et

IR

J

K

L

NMR

$\mathrm{m} / \mathrm{e}$

$\mathrm{Me}$

$\min$

M.p.

MS

$\mathrm{Ph}$

ppm

$i \operatorname{Pr}$

$\mathrm{R}$

THF

$\mu$

V

$v$

Z aryl, aromatic group

average

boiling point

tertiary butyl

calculated

day(s)

density

decompose

degree

hapto

electron impact ionization

ethyl

infared

coupling constant

Kelvin

$\beta$-diketiminato groups (ligands)

nuclear magnetic resonance

mass/charge

methyl

minute(s)

melting point

mass spectrum

phenyl

parts per million

isopropyl

organic groups

tetrahydrofuran

bridging

volume

wave number

number of molecules in the unit cell 


\section{CURRICULUM VITAE}

\section{Personal Information}

Name:

Hongping Zhu

Sex:

Male

Data of Birth:

05, August 1969

Place of Birth:

Jiangsu, China

Parents:

Fenghe Zhu (Father)

Wenying Zhou (Mother)

Family: Qiaozhu Jiang (Wife)

Yicheng Zhu (Son)

Nationality: $\quad$ P. R. China

\section{Education}

Sep. 1977-Jul. 1982: Primary School in Jiangsu, China

Sep. 1982-Jul. 1985: Middle School in Jiangsu, China

Sep. 1985-Jul. 1988: $\quad$ High School in Jiangsu, China

Sep. 1988-Jul. 1992: $\quad$ B. A. Study in Department of Chemistry, Xiamen University, Fujian, China

May 1995-Oct. 1999: M. Sc. Study in State Key Laboratory of Structural Chemistry, Fujian Institute of Research on the Structure of Matter, Chinese Academy of Sciences, Fujian, China

Oct. 2001-Dec. 2001: M. Sc. Equivalence in Institute of Inorganic Chemistry, University of Goettingen, Germany

Jan. 2002-Jul. 2005: Ph. D. Study in Institute of Inorganic Chemistry, University of Goettingen, Germany

\section{Research Experience}

Aug. 1992-May 1995: Working in Catalytic Laboratory, Fujian Institute of Research on the Structure of Matter, Chinese Academy of Sciences, Fujian, China

Nov. 1999-Sep. 2001: Working as an Assistant Professor in State Key Laboratory of Structural Chemistry, Fujian Institute of Research on the Structure of Matter, Chinese Academy of Sciences, Fujian, China 